\author{
UNIVERSIDADE DE SÃO PAULO \\ ESCOLA DE COMUNICAÇÕES E ARTES \\ PROGRAMA DE PÓS-GRADUAÇÃO EM COMUNICAÇÃO
}

MAURÍCIO BARBOSA DA CRUZ FELÍCIO

\title{
DIREITO AO ESQUECIMENTO E A MEMÓRIA DOS SUPORTES TÉCNICOS
}

São Paulo

$(2015)$ 


\title{
DIREITO AO ESQUECIMENTO E A MEMÓRIA DOS SUPORTES TÉCNICOS
}

\begin{abstract}
Dissertação de mestrado apresentada ao Programa de Pós-Graduação em Comunicação da Universidade de São Paulo, como parte dos requisitos para a obtenção do título de Mestre em Comunicação.
\end{abstract}

Área de concentração: Interfaces Sociais da Comunicação

ORIENTADORA: Prof ${ }^{a}$ Dra. Lucilene Cury

São Paulo

(2015) 


\title{
DIREITO AO ESQUECIMENTO E A MEMÓRIA DOS SUPORTES TÉCNICOS
}

\author{
Esta dissertação foi julgada adequada para a obtenção \\ do título de Mestre em Comunicação e aprovada em \\ sua forma final pelo Orientador e pela Banca \\ Examinadora.
}

Orientador:

Prof $^{a}$ Dra. Lucilene Cury, USP

Doutor pela Universidade de São Paulo - São Paulo, Brasil

Banca Examinadora:

São Paulo, agosto de 2015. 
Dedico este trabalho e minha vida a minha família

Paideles, Mãedeles, Mané, Zi

Jacy, Mário, Barbosinha, Célia

Grandes e Pequenos

Novos e Velhos

A todos que são presentes

Dedico a Deus 


\section{AGRADECIMENTOS}

Estes agradecimentos são o reconhecimento àqueles que participaram desta conquista, que jamais será minha, senão de todos nós.

Meu mais sincero obrigado a minha orientadora, Prof ${ }^{a}$ Dra. Lucilene Cury, por me acompanhar nesta jornada e por corrigir meus rumos.

Obrigado ao PPGCOM - ECA/USP por acreditar em meu potencial e me apoiar na continuidade dos meus estudos.

E de todo o meu coração, obrigado a cada professor que me permitiu conhecer mais do que jamais imaginei, a cada aluno da USP que me confiou seu aprendizado e assim muito me ensinou, e a todos os amigos por participarem do meu crescimento a cada dia.

Por fim, mas de toda a minha alma, obrigado ao meu pai por sem meu esteio, minha mãe por ser minha graça, meus irmãos por serem meus maiores amigos, meus amigos e orientadores por serem parte de mim.

Quando, ao final de tudo, perguntarem a mim o que fiz desta vida, terei prazer em corrigi-los. Direi de tudo que fizemos juntos. E direi que somos felizes.

Obrigado a Deus por permitir que nos tornássemos a melhor família que se pode imaginar. Obrigado por todo o amor que nos reúne. Obrigado por toda a fé. 


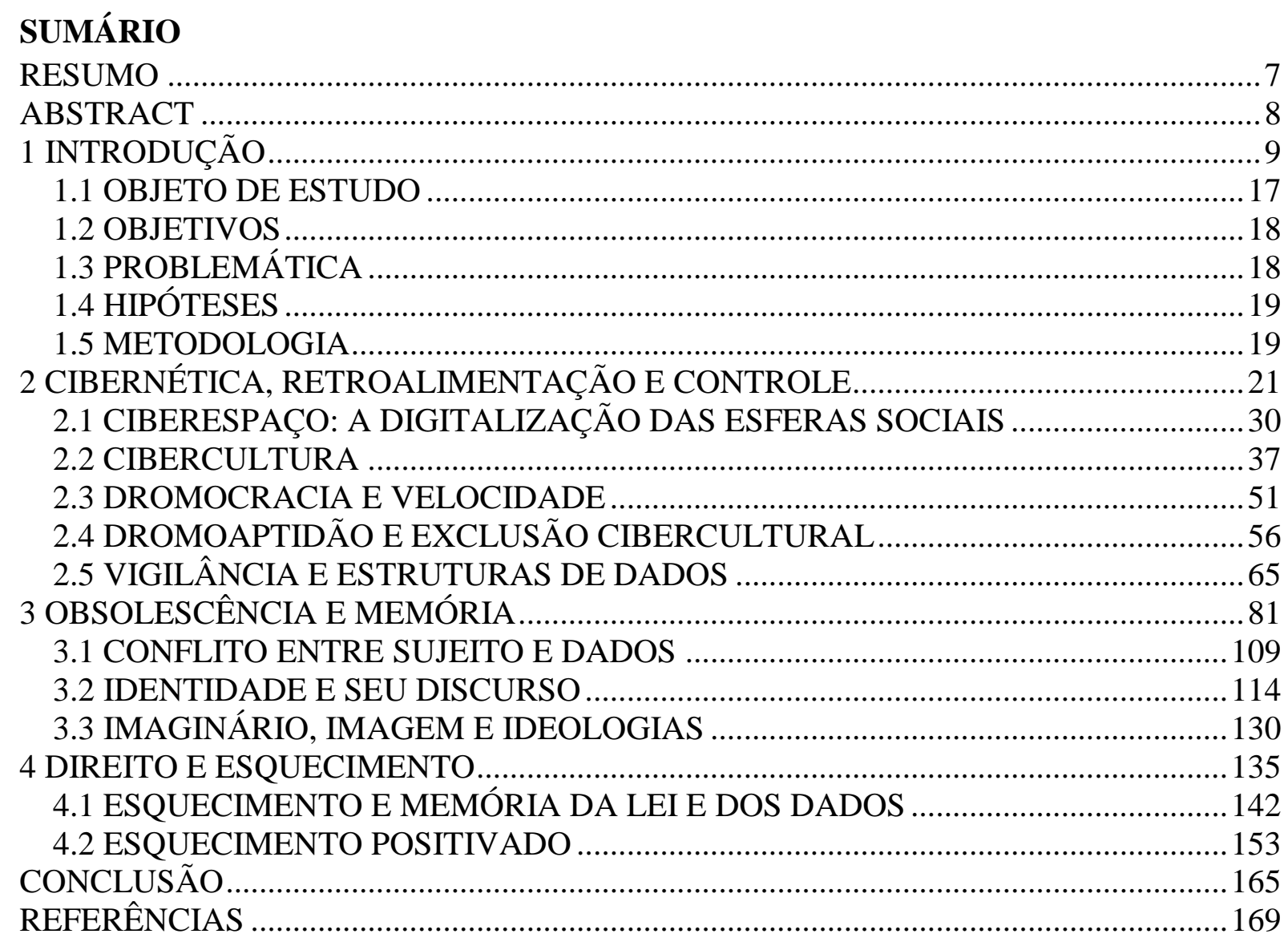




\section{RESUMO}

Este trabalho debate o direito ao esquecimento em uma sociedade amplamente mediada por tecnologias digitais. Entre os principais quesitos, será possível verificar que a aceleração das comunicações está baseada no imperativo de velocidade que se fortaleceu ainda mais com a cibernética, sendo a viga-mestra da cibercultura.

Tal aceleração conduzirá o estudo para a avaliação dos discursos identitários, bem como sobre a privacidade, sua invasão e evasão, além do assédio violento e sutil da velocidade para que os indivíduos explicitem seus gostos e características que serão usados como artefatos de memória digital, construindo bancos de dados interconectados que conforto e praticidade, mas por outro lado também podem ser convertidos em tecnologias de vigilância e controle.

Neste sentido, a inversão do custo das memórias e do custo do esquecimento pautará o debate que pretende explicitar algumas barreiras contemporâneas para que o esquecimento continue a desempenhar seu papel social, além da dificuldade de compreender o poder dos filtros algorítmicos quando se está submerso na cibercultura pantópica.

Palavras-chaves: Cibercultura, Esquecimento, Identidade, Velocidade. 


\begin{abstract}
This paper discusses the right to be forgotten in a society largely mediated by digital technologies. Among the main questions, it will become possible to verify that the acceleration of communications is based on the imperative of velocity that was strengthened even more with cybernetics, and the frame-work of cyberculture.

Such acceleration will lead the study for the evaluation of identity discourses as well as on privacy, its invasion and evasion, in addition to violent and subtle harassment from velocity to individuals to release their wills and characteristics that will be used as digital memory artifacts, building interconnected databases to provide comfort and practicality, but which can also be converted into surveillance and control technologies.

In this sense, the cost inversion of remembering and oblivion will guide this debate that aims to clarify some contemporary barriers to oblivion continues to play its social role, besides the difficulty of understanding the power of algorithmic filters when one is submerged in the pantopic cyberculture.
\end{abstract}

Keywords: Ciberculture, Oblivion, Identity, Velocity. 


\section{INTRODUÇÃO}

São 5 horas e 32 minutos e seu celular toca, tirando-o da cama assim que percebe que saiu de seu sono REM, uma forma de economizar tempo de sono infrutífero para o descanso.

Em quinze minutos está saindo da ducha matinal e já sente o cheiro do café e de pão fresco. Integrados, cafeteira e forno trabalharam enquanto a banheira esquenta. Como chove muito lá fora, um alerta sutil soa indicando que o trajeto para o trabalho estará mais complicado nesta manhã.

Serão necessários 56 minutos para estar em seu escritório, alerta o dispositivo.

Acaba de sorver seu café da manhã, apanha o paletó e entra no carro que, para seu conforto, foi climatizado pelo computador de bordo em temperatura de $25^{\circ}$ Celsius. Alguns atalhos tiram seu Tesla do engarrafamento, com direito a escapar do rodízio e dos radares.

Quando atravessa a ponte que dá ao seu escritório, um som sutil alerta para o aniversário de suas melhores amigas.

Ao chegar ao escritório, os e-mails já estão lhe esperando com a ordem de prioridade indicada na lateral do título, e sobre sua mesa estão o arranjo de lírios e a garrafa de vinho prediletos de sua colega aniversariante, junto ao cartão de felicitações que precisa assinar antes do envio.

Nada como um toque pessoal a caneta para lembrar da estima.

11 horas da manhã, sua tela é bloqueada para que faça a pausa para exercícios ergonômicos e tome seu suplemento vitamínico. 12 horas e 30 minutos, seu celular vibra para que escolha seu almoço no aplicativo de entregas executivas. A pausa para o almoço ocorre pontualmente às 13 horas.

Não é preciso continuar esta história para que fique mais claro que tudo o que está descrito acima, mesmo que em tom meticuloso e maquínico, é uma realidade possível nos dias atuais.

Desde o aplicativo de celular que estuda seus movimentos durante o sono para avaliar se você está em sono profundo ou leve, como é o caso do SleepTime, que além de tudo traz gráficos e informações mais detalhadas de seu sono, até a conexão entre celular e outros utensílios domésticos, como cafeteiras, fogões, torradeiras etc.

O cálculo exato do tempo de trânsito já é extremamente preciso através do Waze. 
Carros com computador de bordo ditos inteligentes já estão à disposição do consumidor com maior poder aquisitivo.

Os alertas geolocalizados são coisas comuns na maioria dos aparelhos celulares.

Sistemas de e-mail como o Gmail já estudam seu comportamento para entender qual tipo de e-mail seria mais importante do que outros de acordo com o assunto ou mesmo com a sua relação constante entre as pessoas envolvidas.

O vinho e as flores prediletas de alguém são informações entregues indiretamente por suas redes sociais.

O aplicativo de restaurantes para entrega do cardápio já traz seleções mais indicadas para o perfil de cada comprador, indicando o tempo de chegada, em alguns casos.

Os suplementos vitamínicos agora podem ser produzidos de acordo com o estudo do DNA de cada pessoa, entregando benefícios específicos e adequados às idiossincrasias individuais, fazendo de Gattaca um filme menos ficcional do que pode ter se imaginado outrora.

Os tempos do software chegaram e a grande explosão de conteúdo já está evidente há alguns anos.

De forma paulatina, a indústria de tecnologia vem se desenvolvendo para que os hardwares possam acompanhar esta evolução do universo da programação. Tecnologias móveis, vestíveis, das coisas. O tempo atual é o tempo dos dados. Da comunicação pessoamáquina, máquina-pessoa, ou mesmo máquina-máquina.

Não estamos mais no campo dos efeitos intencionais, ligados a um contexto de comunicação limitado no tempo e caracterizado por objetivos que visam obter mais efeitos: passamos agora para efeitos em certa medida latentes, implícitos no modo como determinadas distorções na produção das mensagens se reverberam no patrimônio cognitivo dos destinatários. Hoje, no centro da problemática dos efeitos, coloca-se, portanto, a relação entre a ação constante dos meios de comunicação de massa e o conjunto de conhecimentos sobre a realidade social, que dá forma a uma determinada cultura e nela age dinamicamente. (Wolf, p. 142)

Levando em conta que na passagem acima Wolf se referia às novas tendências de pesquisa no campo da comunicação de massa, e por novas estão datadas as projeções do ano em que a obra fora publicada, a saber, 1985, constata-se que a cibercultura ainda não mostrara seu espectro na vida social de forma contundente.

Assim, prolongando as palavras de Wolf, ainda que à época houvesse um distanciamento das teorias de comunicação de massas que avaliavam se haveria a hegemonia 
intencional e um emissor consciente, manipulador, os dias atuais acabam por misturar ambos os cenários, na medida em que não há um conteúdo programático ideológico definido por um grande controlador da mídia, mas ao mesmo tempo há um enclausuramento da vida social que deve passar pelas redes digitais. E na medida em que as redes se tornam capazes de autoreferenciar o sujeito, usando dados individuais para personalizar conteúdos e sites inteiros, espelhando seus gostos nos artigos comunicacionais e culturais que consome, o repertório, ou nas palavras de Wolf, o patrimônio cognitivo dos "destinatários" (sic) poderá sofrer golpes duros em suas características proteiformes.

O conhecimento adquirido anteriormente sobre os acontecimentos, cujas atualizações formam o noticiário, parece incidir conforme duas direções:

a. a memorização se concentra mais na informação já adquirida do que na nova. A familiaridade com o argumento acrescenta, portanto, a facilidade de memorização.

b. Dentre as informações novas, parece privilegiada a cronologicamente mais recente (os últimos desenvolvimentos de um fato) em relação à que amplia os conhecimentos (ou seja, a informação de fundo). (Wolf, p. 172)

Este é o resumo do trabalho de memorização dos textos informativos produzido por Larsen. Indica-se a questão da memória como central na forma como uma notícia é tratada, isso quando pensamos nos efeitos da grande mídia, mas também como as mensagens em contextos digitais, fazendo aqui uma apropriação do conceito, pode estar sujeita aos temas já conhecidos, e novamente, autorreferentes, além da valorização do conteúdo imediato.

E esta comunicação baseada na mensuração binária, no digital, de zero-uns, está a mapear os comportamentos humanos muito além da internet e das redes conectadas.

[...] even if users would have perfect knowledge of the continuous and comprehensive digital remembering of their activities, the only easy remedy available to them would be to turn into digital recluses and abstain from taking part in online interactions, and many offline ones as well. This is because every communication with the world produces a piece of information. [...] And insofar as such communications is using any digital devices along the way, chances are it will be added to our digital shadows. (Mayer-Schönberger, p. 88)

Começa-se a avançar a passos mais largos para a extrapolação dos dados coletados através de ferramentas e tecnologias digitais para desenvolver perfis mais precisos de comportamento, além da alta compatibilização de bases de dados para cruzamentos de informação entre diferentes grupos de interesses.

Este trabalho foi proposto para debater e manter vivos questionamentos a respeito de alguns impactos que a estrutura técnica de dados tem e terá sobre a sociedade e sobre os indivíduos, passando por temas como a memória e o esquecimento na rede, o que se mostrará um caminho com muitas encruzilhadas, trazendo a tona pontos como privacidade, vigilância, controle e liberdade, cultura e violência, filtros e autorreferência. 
Ainda que o tom majoritário seja se alerta, há ainda o contraponto do plano imaginal que resgata a polissemia e também a sua polivalência.

Todo imaginário é real. Todo real é imaginário. O homem só existe na realidade imaginal. Não há vida simbólica fora do imaginário. [...] o homem é movido pelos imaginários que engendra. O homem só existe no imaginário. (Silva, 2012, p. 7)

Se no imaginal se funda o sujeito, nele não se permitirá a determinação, o controle inquestionável. Esta visão precisará se manter presente ao longo das páginas vindouras para garantir que qualquer pensamento determinista enfrente a dúvida imaginal. $\mathrm{O}$ imaginário, como berço e como conflito, não será silenciado.

A se questionar, seguirá a obra buscando traços da existência do homem contemporâneo em suas comunicações, atos e nas estruturas de dados que estão a lhe assediar com seus próprios dados.

Desta forma, o ponto central do trabalho seguirá com o direito ao esquecimento, mas este tema abrange diversas frentes. Assim, espera-se ir um pouco mais a fundo nos estudos a respeito do que se convencionou chamar de Direito ao esquecimento nos campos da comunicação digital.

A proposta que se baseia no termo esquecimento, que inicialmente pode fomentar um certo incômodo em uma sociedade na qual as redes sociais, a mídia e sua publicidade, o jornalismo trabalham no campo da visibilidade, ou do espetáculo, como retrataria Debord (1954) na sociedade capitalista como um todo, e por outro lado chama a atenção ao direito, e, como tal, ao papel da tutela do Estado através das estruturas legais e também dos direitos consuetudinários socioculturais, o que se mostrará algo ainda mais complexo do que se imaginava inicialmente.

Durante os estudos, buscará evidenciar que não apenas a dualidade cartesiana que coloca a memória versus o esquecimento enfrentaria diversos ataques, culminando não mais em um contraste, mas numa tipologia mais próxima do pensamento webberiano, onde os tons de esquecimento e memória se misturam em uma dinâmica plástica, enevoada, ao mesmo tempo em que apenas o texto legal não se mostrará capaz de abarcar o que seria um direito pretendido, mas ainda não oficializado nas letras constitucionais.

Será preciso ir, neste contexto, além da positivação do direito, ou seja, além de suas letras na Carta Constitucional ou em seus Códigos, buscando entender brevemente a distinção entre o que a lei não proíbe e aquilo que ela pretenderia salvaguardar. 
Os poucos textos legais que tratam mais recentemente do que pode vir a ser considerado um Direito ao Esquecimento Digital alocam tal contenda no âmbito da dignidade humana, entendendo o caráter antropocêntrico do direito nacional brasileiro. Ou seja, muito se fala em direito à privacidade, em honra ou mesmo em direito ambiental, que em momento fortuito será tratado nesta análise para compreensão de seu papel neste contexto em tela, mas o esquecimento em si surge como resultado muitas vezes não pretendido de forma direta, mas sim indireta.

Desta forma, enquanto a memória e o esquecimento digitais se mostrarão não apenas como extensões protéticas das habilidades humanas, no sentido mcluhaniano, o direito recoloca o sujeito na lide. Máquina e homem farão seu embate, mas as armas que pareceriam eleitas a princípio se mostrarão ainda multifacetadas.

Os impactos e desdobramentos da memória e do esquecimento levam este trabalho a caminhos amplos e a debates necessários para a sociedade contemporânea e futura.

Como rege o preceito científico-metodológico, as hipóteses foram lançadas com base no recorte de pesquisa, acreditando-se em sua precisão, mas a jornada se mostrará ampla de qualquer forma, conquanto o esquecimento está relacionado à humanidade, mas suas bases estão além da fisiologia, atingindo também a cibernética, e desta forma, a própria cibernética terá seu papel e seu impacto sobre o indivíduo que lembra ou é lembrado.

Em resumo, enquanto as menções mais recorrentes a respeito do direito ao esquecimento digital se referem a ações contemporâneas contra empresas como o Google, exigindo que alguns dados pessoais ou notícias específicas sejam ocultadas, este debate terá corpo nas páginas seguintes apresentando mais do que o conflito entre uma ou outra empresa e um ou outro cidadão.

Os passos a serem dados conduzirão os estudos da cibernética, em um primeiro momento, à cibercultura. A tecnologia, nunca neutra, será posta na berlinda para apresentar suas forças na medida em que toquem o tema proposto.

Como já sugeria a "Primeira Lei de Kranzberg: 'A tecnologia não é nem boa nem má, nem neutra'. Para o bem ou para o mal, os programadores e engenheiros de software estão numa posição de grande poder para mudar o futuro da sociedade.” (Pariser, p. 167).

Tal poder estará descrito nas páginas vindouras que tentarão apresentar de modo mais complexo a forma como o universo da programação, combinado com os modelos preditivos 
estatísticos e as estruturas de inteligência artificial, encontrará terreno fértil na subserviência coletiva em troca de comodidade e agilidade.

Spyer (2007) vai indicar alguns benefícios atrelados aos ambientes virtuais, como redução no custo de produção e disseminação de conteúdo; redução do esforço de coordenação para reunir pessoas com interesses similares; ampliação do benefício no que se refere à reprodutibilidade e disponibilidade de arquivos públicos; e redução do número de envolvidos na produção.

O mundo do possível, do programável, estará colocado sob os mesmos olhares que as estruturas de memória, vigilância e controle, pois seus aspectos de difícil dissociação mostrarão parte de suas faces ao longo do texto e receberão o aporte analítico de diversos autores, bem como a questão do custo, ou da economia, a cerca dos processos de esquecimento e construção de bancos de dados.

O mesmo serve para a afirmação de Rüdiger, quando apresenta em sua obra a afirmação de que "a internet não é neutra, porque seu uso, se não seu desenho, depende de condições sociais determinadas." (Rüdiger, p. 37).

Note-se que o autor não está aqui falando da tecnologia como um todo, mas derivando a lei kranzbergiana para um objeto específico que vem a ser a internet, ou seja, uma das redes existentes, levantando a questão de que a sociedade também impacta o desenho das tecnologias que coloca a seu próprio dispor e pelas quais é influenciada de modo reflexivo e dinâmico.

Significa dizer que alguns pontos importantes que gravitam esta contenda terão sua voz apresentada, como o imperativo da visibilidade nos tempos atuais, principalmente no tocante ao que Trivinho (2007) destacará como a dromocracia cibercultural, em sua obra homônima, deflagra a violência suavizada e sutil da agilidade requerida nos dias atuais para todo aquele que quer ser reconhecido como interlocutor capaz nos espaços públicos.

A propósito, por dromocracia o autor indica ser o "dromos, prefixo grego que significa 'rapidez', vincula-se, obviamente - com base na dimensão temporal da existência -, ao território geográfico (na qualidade de coordenada espacial), portanto à urbis.” (Trivinho, p. 46)

Assim, para compreender o direito ao esquecimento, é mister avaliar também quem ou o que se pretende ser esquecido, em tempos de tamanha velocidade, por quem e de que forma se 
pretende esquecer. Esta pergunta será a viga mestra desta obra, indicando o tom da pesquisa e ao mesmo tempo a lacuna ainda existente.

Mas antes de iniciar a sequência de capítulos que buscarão apresentar corpos correlacionados e congruentes que dialoguem com esta proposta, é necessário destacar que ainda há mais questões do que respostas nos campos frutíferos da comunicação digital, fazendo colidir os estandartes de tecnófilos e tecnófobos.

De qualquer forma, a propagação de um possível direito individual de ser esquecido receberá a resistência dos partidários do direito à informação ou mesmo a liberdade de expressão, não apenas jornalística, que colocarão em confronto o interesse do indivíduo e o interesse da coletividade.

Mas quando os discursos entre o esquecimento sobre algo pretérito de um indivíduo for contraposto com o interesse de perpetuidade e transparência de toda uma sociedade, pode-se antever que o confronto performático, ou espetacular, para seguir a referência Debordiana, que acaba por ganhar os contornos imagéticos que desviam o olhar sobre os outros aspectos de tal debate.

Em outras palavras, quem é este todo inominável e irredutível que requisita de modo etéreo um conhecimento a ser potencialmente utilizado por qualquer agente indiscriminado? Seria ele a sociedade? Talvez fosse possível, em um rompante, dizer que sim, que é a sociedade. Mas logo surgiriam outros questionamentos. Qual sociedade seria esta? Todas? Somos todos membros de uma mesma sociedade? Seríamos os agentes racionais ou o suporte de uma informação que pretende se perpetuar e, ignorantes, seguimos sonâmbulos pelo rio da informação que segue seu fluxo a despeito de nossas particularidades? Seria o capital a exigir esta transparência vigilante? Seria a velocidade?

Tantas dúvidas reunidas soariam uníssonas a indagar quais são os agentes mais relevantes neste embate silencioso que já se opera através da comunicação e de seus suportes tecnológicos, mas que não se restringe a eles.

Enquanto este debate sobre o direito ao esquecimento pode parecer circunscrito, à primeira vista, à internet, tal engano precisará ser desconstruído a fim de se compreender a permeabilidade da comunicação independentemente das barreiras artificialmente concebidas para sua convergência. 
Ainda que a proposta de pesquisa pudesse, a princípio, aparentar tal circunscrição, tornar-se-á difícil evitar sua relação indiscriminada da rede rizomática de memória que dá base para tal debate com o sujeito atuante em sociedade de modo amplo.

Ou seja, não se pretenderá operar tal visão excluindo o sujeito desconectado da internet, já que as estruturas de memória e o conhecimento perpetuado pela rede não aceitam restrições a sua pressão, ou mesmo opressão, para que operem apenas nos domínios eletrônicos dos servidores, websites, aplicativos, internet banking etc.

Desta forma, sem muitos muros, a velocidade encontrará poucas barreiras, e exigirá a aceleração das comunicações no que será chamado de dromoaptidão por Trivinho (2007), um imperativo que aumentará a força excludente de muitos indivíduos da sociedade infotécnica da cibercultura.

A exigência compulsória de dromoaptidão é um pesado fardo para o cérebro humano (norteado pelo logos ocidental), sistema biopsíquico cultural historicamente herdado que, do ponto de vista do simbólico processado ao nível racional (instrumental ou abstrato), tem na lentidão um dos atributos definidores de sua própria identidade. A vida tutelada pela lei da velocidade vai, pari passu, corroendo os seres, até esboroar (por assim dizer) a sua interioridade [...]. (Trivinho, p. 99)

Tamanha aceleração deslocará o sujeito do seu espaço e de seu tempo, desconstruindo sua memória e transformando suas relações sociais mediadas pela tecnologia.

Uma das mais tradicionais formas do comportamento humano, a solidão, acaba de
mudar de endereço e forma. Classicamente, solidão era a condição dos humanos que
viviam reclusos ou em ambientes sem convívio com outros humanos. Em recente
pesquisa desenvolvida nos países da Organização para a Cooperação e
Desenvolvimento Econômico (OCDE), foi colocada em pauta a seguinte pergunta:
para você, o que é hoje a solidão? A maior parte dos pesquisados respondeu que
solidão é não estar conectado. (London, p. 19)

Quando o conceito de solidão está ligado ao ostracismo infotécnico e à falta da conectividade, fica mais sensível e perceptível que a comunicação, irrefreável, carregará os esporos do virtual que germinarão no campo fértil da cibercultura, que não tem morada cativa nos limites eletrônicos da internet, mas sim na dinâmica social vigente, principalmente.

Assim, diversos termos serão combinados na mesma análise.

Espera-se que, ao final desta obra, violência, vigilância, controle, transparência, agilidade, memória, esquecimento, tecnologia, dados, filtro, dignidade, sujeito e cultura sejam termos facilmente correlacionáveis, dada sua proximidade por vezes pouco deflagrada nos dias atuais, e, seguindo Mayer-Schönberger em suas palavras que serão relevantes na construção desta obra. "Most importantly, though, my aim is to help us take steps to ensure we'll remember how to forget in the digital age." (Mayer-Schönberger, p. 15) 
Se lembrar foi o desafio histórico de muitas gerações, a sociedade atual estará, pela primeira vez, enfrentando um novo tirano. Esquecer será o próximo grande desafio.

\subsection{OBJETO DE ESTUDO}

De modo mais específico, o objeto de estudo desta dissertação é o direito ao esquecimento dentro do campo da comunicação, como fator de garantias ou, ao menos, de tentativas de prover condições de constituição discursiva por cada indivíduo sem que lhe seja obrigado seguir um caminho determinado por seus atos pretéritos.

Poderá ser observado, ao longo desta obra, que o esquecimento está ligado de modo profundo a diversas frentes de estudos que pela contingência das limitações tanto de escopo quanto de tempo não serão plenamente abarcadas por esta incursão, mas que serão por vezes aventadas a fim de permitir que qualquer leitor possa tomar para si alguns dos desafios propostos.

É de extrema relevância destacar que por mais que o direito ao esquecimento esteja no cerne do debate, o caminho para chegar até ele passará, de modo um pouco mais demorado, pelo contexto em que se insere.

Outro ponto relevante é que o termo "direito", para esta obra, não está relacionado apenas à estrutura legal, jurídica, mas também se conecta à percepção de direitos, que pode não ter um vínculo direto com o direito positivado, ou seja, com o direito escrito, mas com a noção de moral e ética do que por ventura seria um direito consuetudinário ou habitual.

Na mesma medida, o termo esquecimento está ligado à memória, em sua outra via, e é justamente o confronto entre as estruturas de memória infotécnicas e seu assédio ao presenteísmo, que será melhor trabalho ao longo das próximas página, campo de batalha no qual se dará a análise em questão.

Por fim, ao unir os termos "direito" e "esquecimento", espera-se tornar mais clara a dicotomia que se estabelece em uma disputa não apenas simbólica ou econômica, mas também legal sobre os aspectos comunicacionais que acabam sendo impactados pelo aparato tecnológico dos meios de comunicação digitais, bem como de sua influência e pervasividade frente e junto a outros meios de comunicação. 


\subsection{OBJETIVOS}

É, de modo declarado, relevante para este trabalho:

- Avaliar se há condições de considerar como existente o direito ao esquecimento através do estudo das estruturas infotecnológicas no esquecimento e seu papel na dinâmica e ecologia comunicacional.

São, então, objetivos derivados deste:

- Referenciar o contexto histórico em que a cultura contemporânea germinou e floresceu;

- Apresentar aspectos relevantes sobre o impacto dos bancos de dados e das estruturas algorítmicas na memória e esquecimento na sociedade atual;

- Sinalizar e debater alguns nós e lacunas entre a legalidade, legitimidade e ética ligados às estruturas de dados.

\subsection{PROBLEMÁTICA}

Na medida em que o sujeito contemporâneo segue expondo seus dados na internet e em redes sociais de modo constante, aproveitando oportunidades mas também incorrendo em riscos presentes e futuros, torna-se inquietante a questão a respeito dos reflexos que este comportamento tem e terá sobre a comunicação e as estruturas infotécnicas de comunicação mediática.

Deste modo, há de se avaliar se o direito ao esquecimento é algo existente e praticado, em um primeiro momento, e se, então, é percebido.

Ainda de modo derivado, e ainda que seja percebido, é também de se ter em vista a avaliação que refletirá em que medida este tipo de debate é praticado e desejado pela sociedade e por seus integrantes.

O caminho, repleto de questionamentos ainda sem respostas conclusivas, será trilhado com a vista posta sobre o indivíduo que hoje pratica ou repudia o direito ao esquecimento independentemente de ter ou não consciência ao fazê-lo.

Na mesma medida, estas não são as únicas inquietações que tangenciam este tema, tão pouco espera-se encerrá-lo, mas ao trilhar os caminhos seguintes, serão companheiras a dúvida e a indagação. 


\subsection{HIPÓTESES}

A princípio espera-se encontrar evidências que indiquem, a despeito de algumas menções midiáticas, que o direito ao esquecimento é algo ainda confrontado por algumas estruturas técnicas que levam à perpetuidade dos dados individuais em rede, dificultando que um fato ocorrido com cada indivíduo seja realmente esquecido ao longo do tempo.

Em consonância, acredita-se ser possível encontrar estruturas de conformação e de estímulos para a conduta do que será considerada a evasão da privacidade através da distribuição pública de dados pessoais indiscriminadamente, como forma de escambo por conforto e praticidades.

Na mesma medida, há a crença de que este estudo poderá ainda indicar caminhos pouco debatidos de modo visível na sociedade sobre estruturas de memória que possuem grande potencial de impacto e corrosão.

Outra expectativa do autor é descobrir-se ignorante frente à ampla gama de desdobramentos e potencialidades das estruturas de comunicação e memória disponíveis ou com indícios mais factíveis de uso futuro para estudar, classificar e manter ativo a história discursiva dos indivíduos sociais.

Na medida em que o estudo for aprofundado, há também a visão de que se apresentarão embates éticos mais complexos do que a visão maniqueísta dos interesses diretos nos dados de cada usuário, ampliando o escopo do debate e clareando seus contornos e urgências.

Ao final, o resultado esperado se consolidaria em uma visão ainda ampla sobre um tema recente, em condições de abrir mais espaço para novos estudos e, principalmente, para novos debates a cerca do tema.

\subsection{METODOLOGIA}

Seguindo o escopo de uma dissertação de mestrado, que se insere na ciência como uma leitura de seus objetos à luz da complexidade envolvida em suas diversas facetas, esta obra se dará através do estudo e levantamento bibliográfico e materiais referenciais que possam ter relação com o tema proposto.

Vale, então, resgatar as palavras de Felinto, pelas quais

"[...] se hoje teorizar significa também, em boa medida, ficcionalizar, é porque se dissipou aquela distância epistemológica que permitia ao sujeito inquisidor 
aprisionar seu objeto. [...] a cibercultura apresenta também uma forte tendência ao apagamento de sua dimensão histórica". (Felinto, p. 44)

Com isso, ainda que em alguns momentos já seja possível antever certos embates que possam soar contrastantes e dualistas, como o direito ao esquecimento indo contra a memória ou mesmo a liberdade de expressão, é mister salientar que todo este trabalho está sustentado por um pensamento não reducionista.

Assim, espera-se que cada leitor possa perdoar alguma frase que possa soar restritiva na medida em que mesmo os temas mais restritos estão postos à leitura não como dogmas, muito menos como fatos concretos e finitos, mas como constatações ou suposições sobre sociedade e condutas nas quais o próprio autor e seus referenciados se inserem na maioria dos casos, e que, na mesma medida, devem ser acompanhadas e lidas de modo a permitir não um enclausuramento temerário ou alarmista, mas como sinais para a tomada de ação e consciência do ser humano.

Em resumo, este trabalho se dedica, dentro do paradigma da complexidade, a expor outras facetas de um tema que aparentemente ainda é retratado em muitos meios de modo marginal.

Para tanto, destaque-se que

A complexidade vai contra o paradigma da simplificação, que estabelece a redução e, portanto, leva ao reducionismo. Também estabelece um tipo de pensamento que separa o objeto de seu meio, o físico do biológico, o biológico do humano; que separa as disciplinas e provoca a disjunção. Por isso, as operações comandadas por esse paradigma são principalmente disjuntas, redutoras e fundamentalmente unidimensionais. (Cury, p. 35)

Desta monta, ainda que se possa usar o filtro determinista para ler cada palavra nas páginas vindouras, é o clamor deste autor que sejam, todavia, lidas de modo a compreender que qualquer cenário pode ter sua versão acentuada para dar maior clareza dos contornos possíveis, mas que nenhum ponto de prognóstico pode ser garantido dentro de e através das sociedades em contextos humanos. 


\section{CIBERNÉTICA, RETROALIMENTAÇÃO E CONTROLE}

Se desde os primórdios da tecnologia a eficiência e na ampliação das possibilidades de ação estavam em sua base, hoje em dia a tecnologia pode estar atingindo camadas extremas deste axioma.

A eficiência no uso de técnicas, conhecimento e aplicação das tecnologias, se mostra em diversos campos da natureza. O ser humano não é o único a utilizar de tecnologia para atingir seus propósitos ou, de modo mais ajustado, para suprir suas necessidades.

Se o macaco consegue utilizar gravetos para coletar formigas de dentro da terra, ou mesmo como alavanca para quebrar ou derrubar um fruto, há também a aranha que produz uma estrutura externa com base em um produto orgânico, sua teia, para auxiliá-la na captura de suas presas. Os exemplos são muitos na natureza.

Alguns poderiam dizer que nosso uso da tecnologia é diferenciado por conta da nossa cognição e linguagem, mas isso seria desconsiderar a própria linguagem como sendo uma tecnologia. É relevante pontuar que o homem se afasta do estado de natureza com a linguagem mas ele não é o único a ter uma estrutura de códigos comunicacionais. Lobos, golfinhos, abelhas.

Se o código é sonoro, hormonal / feromônios ou qualquer outro, o que é relevante é que diversas espécies se comunicam de alguma forma. Novamente não estamos sozinhos nesta classificação.

A distinção do homem entre os demais animais e seu predomínio sobre as espécies já foi justificada de diversas formas ao longo da história.

A língua articulada para produzir sons diversos é compartilhada com alguns pássaros como o papagaio; o polegar opositor existe em outras espécies, incluindo os macacos; o uso de uma grande parte do cérebro ocorre também entre golfinhos.

Um homem pré-histórico vê um galho. Reconhece-o pelo que é. Mas a história não termina aí, pois o homem, ao dialetizar, vê uma imagem duplicada. Ele envesga os olhos sobre o galho e o imagina como bastão. O galho significa o bastão. O galho é um bastão virtual. Substituição. Toda a técnica está fundada nessa capacidade de torção, de desdobramento ou de heterogênese do real. Uma entidade real, imersa em sua identidade e sua função, desprende subitamente uma outra função, uma outra identidade, entra em novas combinações, é arrebatada num processo de heterogênese. É a mesma capacidade de interpretar ou inventar sentidos que se pratica na linguagem e na técnica, na bricolagem e na leitura. (Lévy, 1996, p. 92 93) 
Ou seja, a capacidade de encontrar outro no lugar onde existia um é fator distintivo do homem e da natureza. Na linguagem, na imaginação estão distintos homem e animais. Esta discussão não é o ponto central, mas é apenas um prelúdio, pois em determinado ponto da história da humanidade, o ser humano se distinguiu e se destacou da natureza, extirpou-se dela. A agricultura também foi um dos grandes marcos. O homem não estaria mais tão dependente da coleta ou caça, mas poderia produzir seu alimento e, com o tempo, fortificar suas plantações.

At first, paintings were linked with the supernatural. Cave painters may have drawn animals wishing that this would make them appear. Pharaohs and their family hoped paintings would introduce them to the Gods after their deaths. (Mayer-Schönberger, p. 29)

Se houve o tempo em que o homem pintava sua caça na esperança de que ela aparecesse e lhe resgatasse de sua fome, chega-se ao ponto de atingir o simulacro onde a base material da linguagem se desfalece. Assim, evocada, a caça contemporânea não precisa da matéria de carbono, mas sim de suas partículas eletrônicas e luminosas.

Com um salto na história humana, chega-se ao período das trocas e escambos. Um período sem grandes métricas, mas que foi suplantado pela invenção, em diversas partes do mundo, do que viria a ser o dinheiro.

O valor das coisas agora tinha um denominador comum, seja ouro, prata, sal ou qualquer outro bem de valor compartilhado que serviria como medida de todas as outras coisas. A percepção do tempo, a crença em deidades.

É possível elencar múltiplos produtos das sociedades humanas. Mas a base deste estudo está na tecnologia, e mais precisamente, na tecnologia digital, lembrando que "a tecnologia não se materializa apenas em uma série de bens, mas, também, em uma série de lutas e disputas de cunho e forma sociais [...].” (Rüdiger, p. 65 - 66)

A cada momento da história humana, a tecnologia terá feito parte de um embate mais profundo do que o produto direto de sua produção. Tocará de modo profundo o corpo e a mente humanas.

O salto histórico passa, então, para o interesse deste trabalho, da revolução industrial para a revolução tecnológica, mas não sem antes compreender o papel do conflito, do medo, da guerra neste processo.

Em meados do século passado as Grandes Guerras e a Guerra Fria colocaram os Estados Nacionais em alerta constante. Barbrook indicaria que a internet e as redes não teriam 
encontrado suas primeiras ramificações no ocidente, mas através do cibercomunismo e de alguns desertores do ideal comunista.

As redes não surgiram apenas como recurso militar defensivo; antes foram concebidas como parte de um projeto de reconstrução do conjunto da sociedade capitalista por ex-esquerdistas que se haviam convertido em anticomunistas. Em 1961, o Partido Comunista soviético, seguido pelo tchecoslovaco, estabeleceu o objetivo de promover a informatização de toda a economia, e, encantados com o pensamento cibernético, que viam como 'ciência capaz de regular a construção do comunismo', seus líderes começaram a prometer que, em duas décadas, "o povo russo viveria no paraíso pós-industrial do comunismo cibernético.” (Rüdiger, p. 175)

Enquanto no lado oriental alguns passos foram dados para a construção de sistemas difusos, nos Estados Unidos teria origem o projeto Arpanet, com o objetivo de criar uma rede de nós também difusos que pudesse manter a estrutura de comunicação e inteligência militar ativa mesmo se um dos nós fosse destruído por bombardeio ou invasão.

Para assimilar uma explosão nuclear e continuar funcionando, a infraestrutura da Web foi construída sem um comando central. Isso significa que ninguém é dono dela, ninguém tem o poder de colocar outro para fora indefinidamente. Não existe um botão para ser desligada. E mais: a descentralização das informações permite que a internet não só fure bloqueios e evite a censura como também se autorrepare. (Spyer, p. 208)

Da mesma forma, não há um único botão que desligue a base de dados já coletada sobre cada pessoa no mundo.

Os primeiros computadores (calculadoras programáveis capazes de armazenar os programas) surgiram na Inglaterra e nos Estados Unidos em 1945. Por muito tempo reservados aos militares para cálculos científicos, seu uso civil disseminou-se durante os anos 60. (Lévy, 1999, p. 31)

Assim, dava-se início ao que viria a ser a internet, mas esta história passa pelo modelo matemático de comunicação, focado em cálculos, codificação e decodificação, que traz indícios do que viria a ser chamado de ruído da comunicação, e também o que traz em seu bojo o conceito básico de feedback, ou retro alimentação, pelo qual os sistemas seriam capazes se receber informação externa e, a partir disso, ajustar sua conduta para se manter operante. Esta é a origem, de modo resumido, da cibernética.

Paesani, ao discorrer sobre a cibernética, diz que esta se trata de "sistemas semelhantes a homens artificiais com capacidade para ver, mover e pressentir a realidade externa." (Paesani, p. 29) A visão do autor está atrelada à metáfora organicista para os sistemas tecnológicos, indicando que um aparato tecnológico, antes apenas reprodutor de movimentos específicos ou cálculos limitados, passa a ter acesso a dados externos, assim como muitos organismos captam luz e a interpretam com o que chamamos de visão, ou ondas sonoras, para a audição, as máquinas além de captarem, seriam capazes de usar estas informações para ajustarem seu comportamento. 
Se a princípio isso poderia significar uma máquina capaz de perceber que uma de suas engrenagens foi danificada e, com base nisso, suspender automaticamente seus movimentos para não prejudicar outras peças, o que derivou desta corrente tecnológica foi muito além da mecânica. Enquanto na revolução industrial a eletricidade era convertida em movimento, em luz, na cibernética a luz e o movimento foram convertidos em informação, a priori, e em condutas específicas a posteriori.

Mas o que foi considerado pai do termo cibernética na sua concepção atual, Wiener, detinha seu olhar ao que o título de sua obra esclarece. Ao "uso humano de seres humanos". Um título intrigante não só para a sua época, mas também para os dias atuais.

Até recentemente, não havia palavra específica para designar este complexo de ideias, e, para abarcar todo o campo com um único termo, vi-me forçado a criar uma. Daí "Cibernética", que derivei da palavra grega kubernetes, ou "piloto", a mesma palavra grega de que eventualmente derivamos nossa palavra "governador". (Wiener, p. 15)

Nota-se que então a cibernética estaria atrelada à condução, ao governo de algo, ao controle. E esta palavra será muito importante ao longo deste estudo. Controle é um dos itens mais relevantes da cibernética e para o que veremos logo adiante, para a cibercultura que se fundará sobre as bases daquela. "Sem face e sem centro, a violência da velocidade é o que move a tudo e a todos. Ela é o que faz agir, o que faz fazer, o que faz pensar. Não há vida social que doravante prescinda desse ingrediente estrutural." (Trivinho, p. 95)

Vale destacar, novamente, que sua origem maquínica estava atrelada também ao modo produtivo do maquinário fabril e das teorias da comunicação matemática.

Já Pariser indicará uma origem mais antiga para a cibernética, como terminologia.

"[...] um grupo de engenheiros e cientistas vinha trabalhando na questão [máquinas capazes de aprender] dede a década de 1950, em instituições de pesquisa como o MIT e a Universidade da Califórnia, em Berkeley. A área se chamava 'cibernética' uma palavra retirada dos escritos de Platão, que a criou para denotar um sistema autorregulado, como uma democracia." (Pariser, p. 29-30)

A autorregulação está, então, no conceito do feedback exposto anteriormente, que poderá redefinir os caminhos da máquina ou do grupo social, no caso da democracia, ao perceber qualquer sinal de alerta e erro.

Esta capacidade de receber informações e atuar sobre elas de modo a aprimorar o próprio sistema é algo que as sociedades humanas, e antes delas os organismos vivos, desenvolveram, mas que nos tempos atuais está aplicada em estruturas tecnológicas. 
O inorgânico passa a ter uma camada de recepção, processamento e ação sobre informações que antes estavam sob o domínio dos organismos vivos e das sociedades compostas por eles.

Assim, esta possibilidade sensória de reconhecer alguns tipos de informação e agir sobre ela estará na obra de Wiener, de onde se vê o mesmo sentido, porém mais profundo, do que se encontrou nas palavras de Pariser.

Tal controle da máquina com base no seu desempenho efetivo em vez de no seu desempenho esperado é conhecido como realimentação (feedback) e envolve membros sensórios que são acionados por membros motores e desempenham a função de detectores ou monitores - isto é, elementos que indicam um desempenho. A função desses mecanismos é a de controlar a tendência mecânica para a desorganização; em outras palavras, de produzir uma inversão temporária e local na direção normal da entropia. (Wiener, p. 24)

Os processos entrópicos da mecânica, então, justificariam a ênfase cibernética no controle, a fim de garantir a perpetuidade da conduta mecânica em questão, seja uma máquina parafusadeira, uma esteira etc.

Um dos pontos relevantes desta questão é que se em seu início a cibernética estava mais associada ao modo de produção industrial e, em alguns casos, estruturas produtivas que serviriam, vale destacar, à indústria bélica.

\footnotetext{
Assim como a entropia tende a aumentar espontaneamente num sistema fechado, de igual maneira a informação tende a decrescer; assim como a entropia é uma medida de desordem, de igual maneira a informação é uma medida de ordem. Informação e entropia não se conservam e são inadequadas, uma e outra, para se constituírem em mercadorias. (Wiener, p. 115)
}

Em um segundo momento, quando a cibernética começa a produzir artefatos para consumo massivo e ligado a redes de retroalimentação, esta lógica de controle começa a migrar do âmbito industrial e mecânico para as estruturas sociais, de modo que o uso de tecnologias conectadas em rede passa a oferecer informação para alimentar os sistemas técnicos e estes, com o passar do tempo, passam a ajustar suas características de acordo com este conhecimento e também atuarão para combater a entropia mecânica, de um lado, e informacional, do outro.

Os animais superiores desenvolveram extremidades móveis e órgãos sensórios ajustáveis. Assim, os estímulos recebidos de fora podem ser modificados de duas maneiras: através do movimento dos órgãos motores do corpo, que funcionam como performativos ou executivos e pelo movimento dos órgãos sensórios que funcionam como exploratórios ou investigativos. Os primeiros são comportamentais, realizando atividades performativas, os últimos são captadores de estímulos informativos, realizando atividades exploratórias. (Santaella, 2004, p. 39)

A retroalimentação aparece, então, nos organismos vivos e passa a ser espelhada, como já apontado, copiada e otimizada nas estruturas técnicas e algorítmicas. 
Do ponto de vista do esquecimento, entrópico por natureza, este estará limitado pelas estruturas antientrópicas da cibernética, do controle e da redundância.

A visão utópica e tecnofílica de uma rede salvadora da sociedade coloca sobre os ombros da tecnologia o encaminhamento ético-moral que precisa vir da ação e conduta humanas.

Pensar em uma comunicação plena através de uma tecnologia que solucione os problemas de diálogo entre dois polos humanos é sorrateiramente um pensamento sobre uma imposição totalitária e reducionista dos partícipes do processo comunicacional.

O sonho dos homens desde sempre é diminuir essa defasagem [entre emissor, mensagem e receptor], a utopia de cada nova tecnologia é fazer crer que isso seja possível. Se essas distâncias relativamente têm o inconveniente de reduzir a eficácia de qualquer comunicação, elas têm por outro lado a vantagem, como já se viu, de explicar por que a comunicação raramente é totalitária. (Wolton, p. 104)

O hiato comunicacional está dado pela diferença intransponível dos interlocutores em diálogo.

Quando, se é que isso um dia pode existir, sobrevier um modo de comunicação que encerre os ruídos entre os comunicantes, este mesmo momento será o encerramento do diálogo, encerrando também a distinção dos universos cognitivos dos sujeitos que antes estavam negociando símbolos, e que agora são reunidos em um único organismo. Desta forma, não haverá comunicação como diálogo.

Miller aventará, ainda que sua fala não esteja diretamente no âmbito tecnológico, que

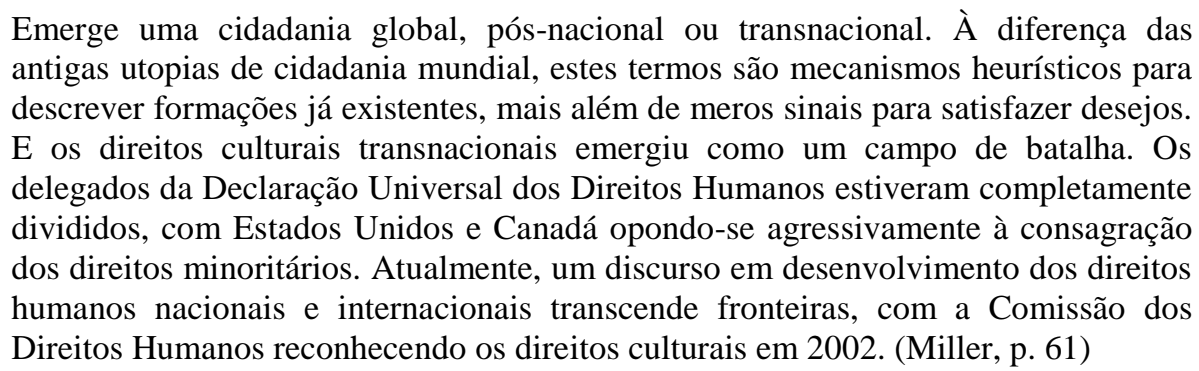

Ao fazer o paralelo, e seguindo o raciocínio elencado, acreditar que a internet, filha da comunicação matemática e da cibernética, vem para resolver todos os problemas de comunicação é reduzir seu potencial e sua realidade. Ela, possivelmente, chega para aumentar os conflitos, seja na reforma, seja na contrarreforma.

London irá no sentido oposto afirmando que "[...] a internet é filha direta da contestação, e não do conformismo, da mediocridade e ad mesmice. O Vale do Silício não 
nasceu no Meio-Oeste americano, mas sim na ensolarada e libertária Califórnia.” (London, p. 125)

Todavia, se a contestação é a prática, o habitus na internet, não significa que esta é obrigatoriamente sua única vocação. A redundância maquínica, do código, da rede oferecerá esforço para combater os desvios mais significativos a princípio e tentará barrar a entropia, mas tal redundância não encerra a comunicação poliforme.

\begin{abstract}
Milhares de indivíduos saem assim, celular à mão, correio eletrônico conectado e a secretária eletrônica ligada como última medida de segurança! Como se tudo fosse urgente e importante, como se fosse morrer caso não pudesse ser encontrado a qualquer instante. Não apenas a multiconexão não garante uma melhor comunicação, como expõe ainda mais a questão da passagem da comunicação técnica à comunicação humana. Na realidade, sempre chega o momento em que é preciso desligar as máquinas e falar com alguém. Todas as competências que se tem diante da técnica não induzem em nada uma competência nas relações humanas. (Wolton, p. 101, grifo nosso)
\end{abstract}

Ainda assim, a vida conectada segue sendo cooptada e o sujeito não seguirá, obrigatoriamente, um caminho emancipatório apenas pelo uso das tecnologias.

Se a princípio fosse mandatório que houvesse um ser humano por traz das máquinas para decodificar os comportamentos humanos derivados de seu uso, e por consequência para lutar contra o esquecimento, num segundo passo os algoritmos passam a abarcar esta função, que ao longo do trabalho ficarão mais nítidas à medida que os processos de construção de bases de dados massivas forem trabalhados.

Para Wolf,

O sistema social no seu conjunto é compreendido como um organismo, cujas diversas partes desenvolvem funções de integração e de conservação do sistema. $\mathrm{O}$ seu equilíbrio e a sua estabilidade realizam-se por meio das relações funcionais que os indivíduos e seus subsistemas ativam em seu complexo. (Wolf, p. 52)

Este complexo social antropocêntrico está, agora, permeado por uma tecnologia capaz de percebê-lo e participar de sua mudança. A se questionar em que medida as transformações sociais em andamento poderão ser compreendidas pelos sistemas infotécnicos de computação algorítmica como entrópicos ou como mudanças sociais importantes para os seres humanos. Em que medida a tecnologia participará mais das transformações positivas do que da restrição do sujeito?

Uma visão estreita da informática, limitada à dialética, a reduz a um conjunto de ferramentas para calcular, escrever, conceber e comunicar mais depressa e melhor. A plena abordagem retórica descobre nela um espaço de produção e de circulação dos signos qualitativamente diferente dos anteriores, no qual as regras de eficácia e os critérios de avaliação da utilidade mudaram. (Lévy, 1996, p. 85 - 86) 
O importante da cibernética é compreender que ela não se encerra em seu entregável material. Ela não é apenas os objetos que ela produz, mas seus símbolos, seus valores, suas linguagens. A ecologia social se transformará, assimilando e sendo assimilada, em uma simbiose da qual possivelmente não seja mais possível extirpar uma ou outra.

No mesmo sentido, entender a cibernética e a máquina é também entender em que medida o homem se tornou máquina e a máquina está, a partir das formas de coleta e percepção do entorno, se tornando homem, ao que inclusive é aludido como sendo o desenvolvimento da inteligência artificial para máquinas de cálculos que agora simulam a linguagem e a interação.

Repito: a realimentação é um método de controle de um sistema pela reintrodução, nele, dos resultados de seu desempenho pretérito. Se esses resultados forem usados apenas como dados numérico para a crítica e regulagem do sistema, teremos a realimentação simples dos técnicos de controle. Se, todavia, a informação que remonta do desempenho for capaz de mudar o método e o padrão geral de desempenho, então teremos um processo a que poderemos denominar aprendizagem. (Wiener, p. 61)

Mas aqui começamos a falar de aprendizagem da máquina, no caso em tela, e não necessariamente apenas da aprendizagem do sujeito que usa a máquina para poder controlá-la, mas também da via inversa pela qual a máquina conhece e aprende ainda mais sobre o sujeito, porém sem as deficiências fisiológicas deste.

Assim, uma nova pergunta se levanta, inquirindo quem de fato estaria aprendendo. E se este aprendizado ocorre em um volume e velocidade completamente desigual e desequilibrado, em que medida ainda será humana, e como tal, ética a avaliação dos produtos sociotécnicos oriundos das tecnologias do conhecimento?

Exemplos como o filme "Ela" no qual o protagonista dialoga e se envolve emocionalmente com um sistema operacional, fruto de programação e de aprendizado artificial, levam ao reconhecimento da dificuldade de definir qualquer tipo de fronteira entre o que foi o artifício do homem e o homem artifício da tecnologia.

Enquanto alguns assistem ao filme acima tomando-o como completamente ficcional, outros conversam do o Siri, aplicativo do sistema operacional iOS utilizado pela Apple em seus telefones celulares.

De todo modo, a meu ver, justamente os processos que, desde a revolução industrial com suas próteses mecânicas, começaram a transformar de forma radical o corpo humano, trouxeram à tona o corpo secularmente recalcado, colocando muito ironicamente em crise o sujeito universal, abstrato. As próteses eletrônicas e, hoje, as digitais, na proeminência corporal que instauram, só acentuaram essa crise. Como nos diz Tadeu da Silva, é no confronto com clones, ciborgues e outros híbridos tecnonaturais que a 'humanidade' de nossa subjetividade se viu colocada em 
questão. Aquilo que caracteriza a máquina nos fez questionar aquilo que caracteriza o humano: a matéria de que somos feitos. A imagem do ciborgue nos estimulou a repensar a subjetividade humana; sua realidade nos obrigou a deslocá-la. (Santaella, 2004 , p. $24-25)$

O homem, neste contexto, não é mais apenas um ente com bases orgânicas. É relevante ressaltar que enquanto por muito tempo as próteses técnicas estavam baseadas em estruturas mecânicas, ainda que interferissem na dinâmica cerebral, hoje as tecnologias informáticas estão prolongando não mais os sentidos específicos ou um membro mecânico, mas o cérebro em sua função de cálculo, decisão e memória, como destaca Kerckhove, discípulo de McLuhan, em seu livro "A pele da cultura".

Assim, enquanto as muletas estavam acopladas ao corpo para auxiliá-lo mecanicamente, o computador está ocupando parte das atividades do cérebro, que por sua vez aproveita a possibilidade de uso de recursos externos para economizar energia. Ou seja, o computador acopla-se ao cérebro na mesma medida que o cérebro acopla-se ao computador.

Não fica tão distante imaginar que esteja correto o autor ao pensar sobre o "livro Out of Control, publicado em 1994 e uma das fontes de inspiração dos criadores do The Matrix" no qual, continua, "o futuro não será o palco de um confronte entre máquinas e seres humanos, mas o lugar onde desaparecerão as diferenças entre natural e artificial." (Spyer, p. 213)

Corso destaca as palavras do pesquisador da Universidade de Toronto, Steve Mann, indicando que "os computadores vestíveis não são gadgets que apenas atachamos ao nosso corpo (como um Ipod ou fone de ouvido), mas sim equipamentos que visam ampliar as nossas capacidade humanas, corporais e mentais." (Corso, p. 2)

Se a cibernética teve seu nascimento nas estruturas mecânicas e fabris, sua adolescência se desenrolou através dos softwares e dos silos da informática, mas seu novo momento de vida está lhe trazendo os ares da maturidade, conhecimento e habilidade para convergir informações e derrubar as muralhas que mantinham as desconexões e reconexões.

\footnotetext{
Quando nos referimos à tecnologia, via de regra, tomamos esse termo em um sentido monolítico, estável. A tecnologia, entretanto, apresenta uma história evolutiva até o ponto de podermos afirmar que, hoje, como quer Stiegler, a tecnologia está orientada para uma profunda transformação de sua própria natureza. (Santaella, 2004, p. 31)
}

Retoma-se então o ponto em que aprendizagem, uma característica até então orgânica, está permeando o silício.

Mas enquanto por muitos anos a copresencialidade fazia parte crucial do processo comunicacional, com o tempo e a midiatização, este cenário se alterou paulatinamente. 
A visibilidade comum é sempre localizada: aqueles que são visíveis para nós são aqueles que compartilham conosco a mesma referência espaço-temporal. A visibilidade é também recíproca (ao menos a princípio): podemos ver aqueles que estão dentro do nosso campo de visão e eles também podem nos ver (contanto que nós não estejamos ocultos de alguma forma). Poderíamos descrever esse fenômeno como a visibilidade localizada da copresença. Mas com o desenvolvimento da mídia comunicacional, começando pela impressa no início da Europa moderna e seguindo pela mídia eletrônica nos séculos XIX, XX e XXI, a visibilidade é liberada das condições espaciais e temporais do aqui e do agora. A visibilidade dos indivíduos, práticas e eventos é liberada da necessidade de dividir um mesmo referencial - é isso que chamo de visibilidade mediada (Thompson, 1995, 2005). Uma pessoa não precisa mais estar presente no mesmo referencial espaço-temporal para ver a outra ou para testemunhar uma ação ou evento. (Thompson, p. 20)

Nesta medida, a visibilidade mediada colocou a mídia como espaço de encontro, como locci do discurso, como espaço de memória de modo mais profundo.

[...] artificial tornou-se nossa memória, desde o momento em que um ancestral nosso, em longínquo passado neolítico, riscou a pedra e perenizou os primeiros sinais indicativos de que ali estava em ação e habitando o mundo uma espécie animal que pretendia deixar marcas de sua existência que sobrevivessem ao artífice que as lavrava. (Palácios, p. 39)

A cibernética, em sua artificialidade, será a memória, o esquecimento, a construção e o apagamento nas sociedades contemporâneas.

\subsection{CIBERESPAÇO: A DIGITALIZAÇÃO DAS ESFERAS SOCIAIS}

Entre os teóricos que tratam do ciberespaço há aqueles que acreditam e defendem uma predominância de um processo de tradução da "realidade" para uma linguagem matemática, calculável, redutível, e que estaria em dissonância ou, ao menos, em desalinho com a realidade material do sujeito que trafega por estes espaços informacionais.

Todavia, há ainda nos textos mais contemporâneos uma visão de que as barreiras entres espaços ditos "reais" e "virtuais" estejam se esfacelando, se é que de fato elas um dia puderam ser consideradas sólidas o suficientes para serem tangíveis. A exemplo, Silva (2006) indicará que

Os espaços híbridos combinam o físico e o digital num ambiente social criado pela mobilidade dos usuários conectados via aparelhos móveis de comunicação. A emergência de tecnologias portáteis contribui para a possibilidade de se estar constantemente conectado a espaços digitais e de, literalmente, se 'carregar' a internet aonde quer que se vá. (Silva, 2006, p. 27)

Assim, há ainda a compreensão de que os espaços podem ser hibridizados, colocando a camada de dados sobre os espaços físicos. Mas para entender o ciberespaço, é preciso ir além da sobreposição. Fragoso vai ainda debater a distinção entre espaço e lugar.

Para além dos binarismos enumerados até aqui, a abordagem da espacialidade pode lançar mão de uma distinção que, por sua extrema simplicidade, constitui um 
instrumental bastante poderoso. Falo da diferenciação entre "espaço" e "lugar" em que, proposição, o espaço é associado a níveis elevados de abstração e o lugar identificado com uma materialidade intrínseca que tem como ponto de partida o sujeito. Mesmo quando tomam como base essa polaridade, tanto os estudos de cibercultura quanto os de outras matérias - inclusive subáreas da geografia - tendem a abordar a questão do lugar enfatizando sua instituição simbólica (o lugar como construção cultural, identitária, histórica), em detrimento dos aspectos relativos à sua materialidade. (Fragoso, p. 184 - 185)

Dá, então, evidência à questão cultural que aflora e se relaciona com o espaço e, como tal, com o ciberespaço.

Mas para compreender a origem do termo, Lévy indica que ciberespaço foi apresentado inicialmente em um romance de ficção científica e seu uso perpetuado até os dias atuais.

A palavra "ciberespaço" foi inventada em 1984 por William Gibson em seu romance de ficção científica Neuromante. No livro, esse termo designa o universo das redes digitais, descrito como campo de batalha entre multinacionais, palco de conflitos mundiais, nova fronteira econômica e cultural. (Lévy, 1999, p. 92)

O romance, que marca a palavra ciberespaço, quando trata de conflitos mundiais, está ainda concentrado nos territórios, nações e leis que formam o tripé estatal, mas nos dias atuais a definição de ciberespaço extrapola as cisões geopolíticas, deixando de ser um território a ser conquistado para se tornar um espaço de preenchimento, de lacunas, de comunicação não apenas de governos, de máquinas, mas de pessoas.

E vale considerar a coincidência interessante referente ao surgimento do termo ciberespaço surge no romance cyberpunk acima, que ironicamente fora concebido em 1984, por William Gibson, data que deu título à obra mais conhecida e impactante de George Orwell.

O ciberespaço possui grande capacidade de armazenar informação, propaga dados em tempo real, realiza conexões mundiais e, pela primeira vez, modifica a relação emissor-receptor: pois teoricamente, todo usuário pode ser receptor e produtor de conteúdo. Se tanto em uma criação, quanto no seu desenvolvimento, demarcam-se uma construção coletivo com diversos pesquisadores lançando e aperfeiçoando softwares, é possível associar certas tendências de horizontalidade, abertura, liberdade e democracia quando se fala de internet. (Fava, p. 2)

A horizontalidade do ciberespaço que aparece na fala de Fava está posta para indicar que este espaço informacional não segue a hierarquia das diversas sociedades que se encontram nele. Enquanto a Índia ainda mantém suas castas, o ocidente mantém as distinções com base no poder aquisitivo ou na língua materna, no ciberespaço não haveria distinção entre poder aquisitivo, etnia ou outros fatores. Todos são comunicadores em potencial, elos comunicantes, elos informacionais.

Defino o ciberespaço como o espaço de comunicação aberto pela interconexão mundial dos computadores e das memórias dos computadores. Essa definição inclui o conjunto dos sistemas de comunicação eletrônicos (aí incluídos os conjuntos de 
redes hertzianas e telefônicas clássicas), na medida em que transmitem informações provenientes de fontes digitais ou destinadas à digitalização. Insisto na codificação digital, pois ela condiciona o caráter plástico, fluido, calculável com precisão e tratável em tempo real, hipertextual, interativo e, resumindo, virtual da informação que é, parece-me, a marca distintiva do ciberespaço. (Lévy, 1999, p. 92 - 93)

Lévy, então, na mesma media que dá dimensões comunicacionais para o ciberespaço, já traz um item que será caro para esta obra. O ciberespaço está posto também como local de memória interconectada dos computadores. Faltou, neste item, a memória externa também da sociedade e dos indivíduos, mas isto virá à tona nesta obra no momento fortuito.

O autor, a quem o conceito de virtual é de extrema relevância, indicará este como marca primeira do ciberespaço. $\mathrm{O}$ espaço plástico, em potência, que tem a capacidade de moldar seus domínios e reconfigurar seus fluxos.

Novamente, com a visão de que a tecnologia está no cerne libertário da inteligência coletiva e da evolução social, Lévy terá contornos afáveis não apenas ao ciberespaço, quanto à cibercultura e ao sujeito cíbrido que pode surgir daí.

Em oposição, Tim Wu indicará que "o crescimento das redes não eliminou os intermediários, apenas os substituiu." (Tim Wu apud Pariser, p. 58) Ou seja, por mais que haja uma mudança através das redes de comunicação digitais no vetor comunicacional, ainda há os intermediários, sejam códigos ou mesmo empresas.

[...] o ciberespaço tende à universalidade e à sistematicidade (interoperabilidade, "transparência", irreversibilidade das escolhas estratégicas) em um sentido ainda mais forte que os outros grandes sistemas técnicos, por ao menos duas razões. Em primeiro lugar, constitui a infraestrutura de comunicação e coordenação dos outros grandes sistemas técnicos. Melhor ainda, assegura a condição de possibilidade de uma progressão na universalização e coerência funcional, organizacional e operacional dos outros sistemas. O desenvolvimento do digital é, portanto, sistematizante e universalizante não apenas em si mesmo, mas também, em segundo plano, a serviço de outros fenômenos tecnossociais que tendem à integração mundial: finanças, comércio, pesquisa científica, mídias, transportes, produção industrial etc. Por outro lado, o significado último da rede ou o valor contido na cibercultura é precisamente a universalidade. Essa mídia tende à interconexão geral das informações, das máquinas e dos homens. E portanto, se, como afirmava McLuhan, "a mídia é a mensagem", a mensagem dessa mídia é o universal, ou a sistematicidade transparente e ilimitada. Acrescentemos que esse traço corresponde efetivamente aos projetos de seus criadores e às expectativas de seus usuários. (Lévy, 1999, p. 113)

Tal visão universalizante, por mais que esteja inserida em um contexto de evoluções tecnossociais, abdica da própria metáfora do universo, que desmembrado tem "uni", de um, e "verso", de versão. Eis então uma versão única de algo que, mesmo na obra levyniana, terá terreno para desdobrar o multiverso plástico do ciberespaço. "Quanto mais o ciberespaço se amplia, mais ele se torna 'universal', e menos o mundo informacional se torna totalizável." 
(Lévy, 1999, p. 111) Esta expressão, então, indicaria não a versão única, mas o caráter universal como a aceitação de tudo dentro de seus domínios.

A visão emancipatória de Lévy ajuda a compreender que cada integrante do ciberespaço e da cibercultura, ainda que dentro do universal, tem condições de se tornar um nó de contestação, de transformação, de reformulação.

Ao pensar nas em tais promessas emancipatórias com base nas tecnologias, Rüdiger vai trazer a reflexão de que há um conformismo e ao mesmo tempo a relegação da tecnologia como a solucionadora dos problemas do futuro (próximo, talvez). Ou seja, imagina-se que seja ela a conduzir as soluções dos problemas da humanidade, em certa escala, no âmbito dos crimes, por exemplo, ou da saúde.

A tecnologia é apresentada como um caminho de auxílio e suporte, sendo que a dianteira desta revisão de valores ainda não foi claramente tomada pela sociedade.

\begin{abstract}
A combinação do poderio sistêmico onipresente com a crescente desintegração das instituições políticas lança-nos em uma situação marcada por crescente conformismo e desorientação, do qual tira partido o projeto tecnológico, ao sugerir que só pela via maquinística podemos ter algum futuro: independentemente de como o avaliarmos, é este fato que explica porque, fora das suas ilusões e promessas, não há projeções utópicas capazes de mobilizar as forças sociais em torno da construção de um projeto de futuro verdadeiramente alternativo para a coletividade, fora das fantasias regressivas dos fundamentalismos religiosos e tradicionalistas. (Rüdiger, p. 180)
\end{abstract}

Há de se citar, que mesmo os defensores de uma tecnologia libertária ainda precisam encarar o fato de que tanta tecnologia não foi capaz de suplantar os interesses econômicos para encerrar a fome no mundo, ou garantir o abastecimento de água para toda a população global, isso sem falar na rede de saneamento básico.

Amir Kassaei, CCO da DDB Worldwide, fez uma das últimas palestras no Cannes
Lions este ano e deu uma bronca no mercado: a propaganda está perdendo a
relevância e se descolando da realidade. Ele acredita que a publicidade voltou seu
foco para a tecnologia, as novas tendências, e esqueceu do verdadeiro consumidor
que está nas ruas e para quem a maioria das coisas criadas, consideradas inovadoras
e criativas, hoje não fazem sentido.i "Publicitários criam 'coisas' que não têm
serventia no mundo real", alfinetou, e ganhou aplausos entusiasmados.

Não apenas a propaganda se descola da realidade, mas a realidade que o autor do trecho acima referencia é aquela ligada à materialidade, ou seja, não é sequer a única realidade possível, mas de certa forma, não erra.

\footnotetext{
${ }^{1}$ Palestra de Amir Kassaei gera debate . Disponível em <http://propmark.com.br/mercado/54342:palestra-deamir-kassaei-gera-debate>. Acesso em: 7 de julho de 2015.
} 
E esta estrutura de espaços virtuais, de espaços digitais, que se apresenta em sua face mais conhecida como a própria internet, já não pode ser considerada restrita e circunscrita nos países do chamado primeiro mundo.

Se você ainda pensa que a internet é um brinquedinho norte-americano com umas poucas ramificações aqui e ali, mude o disco: $42 \%$ dos acessos mundiais vem da Ásia, hoje a líder da internet mundial. Em segundo lugar, vem a Europa, com 24\% dos acesso, e, em terceiro, a América do Norte, com 20\%. Fechando a conta, a América Latina, com 8\%, e a África, com 6\%. (London, p. 41)

Estes dados já pareciam intrigante, com sua atualização em 2013, demonstraram ainda mais a disseminação da internet pelo mundo não americanizado.

Segundo o site "internet live stats", $40 \%$ da população mundial tem acesso à internet desde 2014, o que significa que o acesso praticamente dobrou nos últimos 7 anos, e destes, 48,4\% são acessos realizados em países asiáticos. Ainda que se alegue no passado, por vezes, que os efeitos da cibercultura possam estar restritos aos Estados Unidos e Coréia do Sul, hoje em dia esta máxima já não se aplica.

Somente China e Índia, juntas, somam pouco mais de $30 \%$ do volume total, contra 21,8\% dos acessos vindos as Américas como um todo e 19\% da Europa.

Se a cibercultura é um campo para as polivalências e para a reconstrução da democracia, como alegam alguns, então o centro deste debate poder acabar se deslocando da base grega do ocidente para as filosofias diversas do oriente. Já se outros avaliam o potencial de vigilância das tecnologias de comunicação em rede, os países do eixo oriental seguirão monitorados.

O anuário brasileiro da mídia digital indica ainda que o Brasil (Mídia Dados, p. 390) possui apenas 3,6\% dos acessos mundiais à internet, mas já alcançou uma penetração de $54,2 \%$ de sua população, ou seja, a balança que indicava a prevalência da internet para apenas uma minoria já teve sua inversão. E o cenário muda de figura quando países como Estados Unidos, Reino Unido, Alemanha e Japão beiram os $90 \%$ de penetração da internet enquanto o terceiro colocado, a Índia, tem apenas $20 \%$ de penetração doméstica e a China está ainda em $47 \%$.

O campo de crescimento é considerável e o peso mundial destes acessos poderá ser sentido na forma como a internet e as redes vão se adaptar a este volume de novos entrantes.

\footnotetext{
${ }^{2}$ Internet Live Stats. Disponível em <http://www.internetlivestats.com/internet-users/\#byregion>. Acesso em 10 de junho de 2015.
} 
Se o papel da tecnologia é emancipar o sujeito, e esta é uma suposição, há de se avaliar se isso de fato ocorre, mas isso só será possível ao longo do tempo e após considerar o caminho histórico da cibercultura já consolidado, momento este que ainda é uma promessa ou um porvir, ainda que seu crescimento esteja abarcando muitos países antes marginalizados na corrida cibercultural.

Vê-se, também, Pariser dar luzes à multiplicidade das vozes como um dos fatores de sustentação das potencialidades positivas das redes infotécnicas. Para o ator, "[...] quando existem mais vozes, as pessoas tendem a confiar menos numa voz específica." (Pariser, p. 61)

Mesmo que Pariser esteja se referindo à crise do jornalismo nos tempos de blogs e redes sociais, ao trazer seu texto para esta obra, é possível usá-lo de modo paralelo para indicar que as pessoas passam a desconfiar das informações que estão em dissonância tanto com sua visão de mundo quanto com as vozes majoritárias.

A cibercultura não é, como seus meios, intrinsecamente participatória e democrática, visto que nela se confrontam forças sociais de todos os tipos. Os coletivos progressistas e as subculturas se articulam mais e melhor agora, mas quem tem a hegemonia nos seus fluxos de informação e saber são as forças reacionárias e conservadoras. O fenômeno se articula conforme o ritmo e as circunstâncias de seus embates e confrontos. (Rüdiger, p. 70)

Dobelli trará o detalhamento do que chamará de prova social (social proof). Para o autor,

Prova social, à vezes indistintamente designada como instinto gregário, significa: comporto-me de modo correto quando me comporto como os outros. Em outros termos: quanto mais pessoas acharem uma ideia correta, mais correta essa ideia será - o que, naturalmente, é um absurdo. (Dobelli, p. 24)

Assim, é de se questionar se, ao ter uma inverdade publicada sobre alguém, conseguirá esta pessoa reverter este cenário lutando contra múltiplas vozes que já replicaram o conteúdo indevido em centenas de blogs e sites pela internet? Quando a maioria ratificar, como se corrige um engano? Se o ciberespaço é o campo, o espaço da nova opinião pública, é também o espaço das atualizações da memórias sociais, coletivas e grupais, e em seu terreno o esquecimento pode não ter solo para fincar raízes profundas.

Ou seja, a pessoa, apartada do grupo, tem seu nome envolvido em alegações, e precisará lutar contra não apenas o perpetrador da veiculação inicial, mas com todos que replicaram o conteúdo sem qualquer tipo de apuração, e ainda deverá se tornar mais relevante do que os grandes sites e blogs para que sua resposta, se publicada na internet, tenha mais relevância do que os demais textos, aumentando suas chances de ser lida e, oxalá, creditada. 
Um caso realmente recente comprova a dificuldade de agir contra a maioria nas redes. Lilia Rodríguez, jovem mexicana de 19 anos, teve seu nome usado em um perfil falso nas redes sociais criado por algumas pessoas que queriam the fazer mal. O perfil veiculou informações inverídicas indicando que ela teria AIDS e, de modo premeditado, teria mantido relações sexuais com um homem casado apenas para lhe "dar uma lição". O resultado é que ao inserir seu nome verdadeiro em redes sociais, há 3 meses, a moça se torna vítima de ofensas e ameaças. Para tentar esclarecer a situação, Lilia publicou um vídeo contando sua versão ${ }^{3}$. Mas em quem “a internet” vai acreditar?

Paradoxalmente, o mundo digital, o ciberespaço ou a internet é constituído de narrativas visuais (aí compreendida a escrita) como tecnologia de ingresso e de acesso aos bancos de dados. E se no mundo oral não há possibilidade de formação de memórias auxiliares fixadas em outros suportes porque não existem tais registros fora do pensamento humano, o mesmo não se pode dizer das sociedades da escrita (alfabética) e da sociedade digital (numérica). O suporte digital implica em uma dinâmica compatível com fluidez dos objetos produzidos exclusivamente para a internet e, ao mesmo tempo, parece oferecer uma possibilidade de arquivamento imensa se levarmos em conta as limitações de espaço físico do papel. (Dodebei, p. 39)

A espetacularidade terá morada no ciberespaço, e seus contornos permitirão a disseminação acelerada de comunicações sem a censura prévia da tecnologia. Isso relembra que, uma vez mais, o filtro ético esta posto, ao menos até este momento da narrativa, do estudo, sobre os ombros dos indivíduos, dos usuários da internet.

[...] o ciberespaço e seus efeitos culturais se afastam de modo acelerado daquilo que foi rotulado pelos antigos meios e, superando a linearidade comunicativa, procuramse as circularidades imprevisíveis ou díspares, porque decorrem da indeterminada característica de meios comunicativos que, ambientalmente, contagiam o planeta, mas resistem à sua determinação e controle. Até agora não se pode saber o que é e, especialmente, o que fazer com o conhecimento ciber, embora sejam produzidos unívocos discursos que, descritivos, procuram operacionalizar hipóteses para a realidade que deverá agitar o mundo dominado pela tecnologia ou desenhar o presente com recursos que utilizam imprevistas interatividades ou subjetividades híbridas e móveis. (Ferrara, p. 68)

O ciber de Ferrara é o ciber ainda indefinido, ainda por demais polimorfo que poderá seguir caminhos tão diversos que por ora não se permitira sequer tentar definir de modo mais concreto. Concretude, aliás, está longe do que se apresentaria como característica para o que vem a apresentar as estruturas cibernéticas, ainda que centradas no controle e na mensuração e feedback.

\footnotetext{
${ }^{3} \mathrm{Meu}$ nome é Lilia Rodríguez... e não tenho Aids. Disponível em: <http://mulher.uol.com.br/comportamento/noticias/bbc/2015/07/17/meu-nome-e-lilia-rodrigueze-nao-tenhoaids.htm>. Acesso em 18 de julho 2015.
} 


\subsection{CIBERCULTURA}

É possível questionar se haverá um futuro próximo no qual a cibercultura poderá ser considerada consolidada, ainda mais quando se leva em conta suas características de transformação, seus artifícios e técnicas específicas, sua possibilidade de criação e recriação de universos conectados ou autorreferentes, mas antes de consolidá-la, é também preciso compreendê-la em seus diversos aspectos.

Se a cibercultura traz, com seu braço tecnológico, a disseminação das formas de comunicação, destituindo parte da hegemonia dos meios de comunicação de massas, o faz não sem um preço, oferecendo os riscos atrelados à impossibilidade de concorrer, mesmo em casos de grandes conflitos morais, com a multiplicidade das vozes reprodutoras de determinados discursos.

Neste ponto, a ciência que estuda olhando para o passado terá grandes dificuldades de compreender o ciberespaço, a cibercultura, o organismo cibernético (ciborgue), etc, a menos que esteja preparada para olhar o presente de modo inquisitivo e profundo para que seja possível encontrar os indícios dos caminhos futuros. Tarefa árdua e repleta de riscos.

Falar do futuro é fincar estaca em terreno incerto, de modo que muitos evitam expandir seus estudos para as possibilidades futuras com medo de serem confrontados a posteriori com seus escritos e terem que justificar as falhas que cometeram. A ciência, portanto, precisa prescindir do ego, do medo do cientista individual.

Sem a ousadia de olhar um passado pouco conclusivo, um presente fugaz e imaginar qual das sementes germinará neste solo com mais força fará com que seja possível antecipar debates éticos dos quais, por sua vez, nem a ciência nem a sociedade podem prescindir.

Ao se considerar o binômio espaço-tempo, para tratar dos aspectos específicos da cibernética e seus reflexos, que, quando posto para o ciberespaço, será visto com Trivinho, terá o quesito da velocidade, ou seja, espaços múltiplos de tempo reduzido, conduzindo a uma aceleração desenfreada que move todos dentro do que virá a ser caracterizado como cibercultura.

Haverá aqueles, como Felinto, que considerarão que

[...] se o maior pecado da cibercultura não é a nebulosidade do termo que a expressa, mas sim seu sequestro da história, nem por isso deve-se descartar a hipótese de uma relação íntima entre esses seus dois aspectos. Eliminando a história da origem, repudiando sua gênese, a cibercultura reforça a ideia de uma realidade da ordem do divino (e, portanto, intraduzível em palavras). (Felinto, p. 45) 
A espera para a consolidação do produto desta aceleração cibercultural pode levar a sociedade a estar suficientemente submersa pelos imperativos da cibercultura ao ponto de lhe ser altamente custoso e dificultoso reedificá-la, ainda mais com esta perda de referência histórica.

O surgimento da expressão cibercultura [...] aparentemente deve sua criação à engenheira, informata e empresária norte-americana chamada Alice Hilton. Fundadora do Instituto de Pesquisas Ciberculturais (1964), Hilton foi, com efeito, pioneira ao usar a expressão com o sentido enfático, referindo-se com ela a uma exigência ética da nova era da automação e das máquinas inteligentes. (Rüdiger, p. 8)

Hilton estava apreensiva com o futuro que se veria através da revolução das máquinas inteligentes. Sua visão antecipava e indicava que a humanidade poderia chegar a uma “educação emancipatória", defendia hoje por tecnofílicos como Lévy, ou a uma "idiotia apática", bandeira negra contraposta.

A pesquisadora nutria seu receio com alicerces na dúvida sobre como seguiria o desenvolvimento da cibernética e como a sociedade se estruturaria a partir da automação de máquinas capazes de interpretar informações.

Vale destacar a sua coragem em empenhar seu nome e reputação sobre algo que poderia, como ocorreu, gerar impacto suficiente para ser considerado por muitos pensadores como uma nova revolução.

A ameaça seria a obsolescência, então, do homem comparado à máquina não para o trabalho braçal, mas para a condução social nesta nova era.

Mas se esta questão pode ser considerada pouco debatida ou compreendida, Felinto destacará que há mais um degrau a ser considerado.

[...] a ausência de historicidade que impregna o termo (e a forma de existência) cibercultura expressa seu caráter profundo: essa indefinição constitutiva que se alia a um decidido repúdio do tempo. O paradoxo do nome cibercultura é o fato de que a história que devia carregar foi quase que inteiramente apagada. A história da palavra cibercultura é a história de seu apagamento da história. Nesse sentido, a cibercultura constitui um fenômeno muito particular da contemporaneidade, já que, hoje, a problemática do novo estaria aparentemente superada. Todavia, Boris Groys adverte para o equívoco dessa concepção corrente, sugerindo que as utopias modernas não foram eliminadas, mas que o novo insiste em retornar, ainda que de forma muito particular [...]. (Felinto, p. 46)

A inteligência artificial, por exemplo, que ainda não estava tanto em pauta na época de Rüdiger, segue demandando o debate ético que vem sendo silenciado na grande mídia internacional. 
Se isto se dá por falta de envolvimento histórico do público médio com o que viria ser a ética em si ou se é justamente a ciberética que vem sendo esquecida ou ocultada dos debates é um tema para outro estudo específico, mas à guisa desta penumbra estão germinando condutas que podem ser positivas para o mercado e negativas para a sociedade em longo prazo.

Rüdiger caracterizará a cibercultura de um modo genérico, sem se ater a possíveis vieses positivos ou negativos. Para o autor,

Cibercultura é a expressão que serve à consciência mais ilustrada para designar o conjunto dos fenômenos cotidianos agenciados ou promovido com o progresso das telemáticas e seus maquinismos. Afinando o conceito um pouco mais, poderia bem ser definida como a formação histórica, ao mesmo tempo prática e simbólica, de cunho cotidiano, que se expande com base no desenvolvimento das novas tecnologias eletrônicas de comunicação. Nessa condição, o fenômeno seria explicado historicamente pela convergência do pensamento cibernético e da informática da comunicação, que aquele pensar agenciou intelectualmente, com os esquemas de uma cultura popular que se articulam desde bom tempo de acordo com o que foi chamado de indústria cultural por Theodor Adorno. (Rüdiger, p. 11)

É relevante perceber o caráter constante e contínuo dado por Rüdiger à cibercultura.

Ela é cotidiana, praticada, exercida, e existe desde antes dos dias atuais, das luzes dos telefones de multiprocessadores do século XXI. Em tempo, na medida em que a cibercultura não está, em si, positivada em um código, ou seja, escrita em uma tábula de mandamentos, ela segue praticada a despeito dos esforços para compreendê-la e mesmo restringi-la. Seja o Estado em sua tentativa de vigilância, a ser tratado mais a frente, ou o sujeito a combatê-la ou mesmo também aplicá-la, a cibercultura segue sendo praticada.

Em resumo, ainda que haja um hiato intelectual sobre a cibercultura e a ética em seus domínios, este segue sendo preenchido pelas práticas cotidianas.

A cibercultura, no singular, é, epistemicamente, uma figura típico-ideal abstrata, que nasce da síntese reflexiva e, assim, sempre parcial, de múltiplas práticas, mas nem por isso deixa de ter propriedade intelectual como categoria do pensamento teórico de nosso tempo [...]. (Rüdiger, p. 22)

Pervasiva, a cibercultura, em Rüdiger, não será resumida ao que dizemos sobre ela, assim como qualquer outra cultura que tenhamos classificado ao longo da história da humanidade, mas isso não significa que ela não manifeste suas marcas nas sociedades contemporâneas.

A cibercultura equivale a um processo social-histórico bem mais vasto e complexo do que supõe o imaginário da pesquisa especializada. Ela está já pressuposta no contexto a priori de relação com os próprios media interativos e com o capital cognitivo a eles necessário. É assim que, como categoria de época, ela se confunde, imanentemente, com o cenário material, simbólico e imaginário contemporâneo. (Trivinho, p. 67) 
Trivinho apresenta, então, um ponto importante que vem a ser o pressuposto contextual da relação entre a cibercultura e o cenário simbólico e material, bem como, frise-se, o imaginário. Assim, cibercultura não é algo posto, mas algo plástico e que permeia as mentes e os aparatos sociais contemporâneos.

\begin{abstract}
Entretanto, apocalípticos e integrados são nomes que parecem corresponder ou são lembrados para designar a realidade atual vinculada à emergência da cultura que caracteriza o ciberespaço como decorrência da Internet, entendida como meio comunicativo matriz e da qual decorrem redes, blogs, chats, fotologs, sites, e os novos dispositivos móveis. Todos esses nomes constituem meios comunicativos com distintas atuações, mas eclodem no e a partir daquele espaço. O prefixo "ciber" que atua como predicativo do espaço e da cultura que decorrem do suporte digital não os distingue com clareza no sentido de indiciar hierarquia ou relações entre eles. Entretanto, ambos e, sobretudo a cibercultura, parecem ser credores de um capital cognitivo que transforma a tecnologia digital em um meio comunicativo que promove interfaces, interatividades e longínquas e duvidosas, porém possíveis, inclusões sociais, políticas e culturais. (Ferrara, p. 61)
\end{abstract}

Colocada por Ferrara nestes termos, a cibercultura está creditada em aspectos cognitivos, compreende-se dentro do aparato infotécnico que não abrange apenas os ambientes digitais em si, mas todos os campos nos quais as estruturas da cibernética podem coletar e atuar sobre os dados produzidos.

Ao pensar na forma como os autores ampliam o debate sobre a cibercultura, começa-se a perceber que ao invés de ser resumida, a cibercultura é ampla, é categoria de época, como destaca em letras grossas Trivinho (2007).

Dirá Felinto que ela está derivada da modernidade, o que indicará um caminho histórico a ser pensado para sua arqueologia.

A cibercultura é, nesse sentido, herdeira de diversas questões da modernidade. Elaborar uma cartografia da cibercultura significa também, portanto, desenhar linhas de tempo, paisagens temporais estranhas que conectam épocas distantes e se enraízam no secular projeto tecnológico do Ocidente. (Felinto apud Amaral, p. 48)

A ocidentalização da percepção da cibercultura, referenciada por Felinto, não pode ser tomada como uma restrição geográfica de sua influência ou presença. Como visto anteriormente, a internet, descendente da cibernética, já está ampliando seu alcance, e com a melhor das intenções, muitas sociedades estão clamando por abalar as estruturas que chamam de exclusão digital, exigindo e buscando acesso à internet e às suas tecnologias de apoio.

Ao pensar no vínculo não apenas com o tempo, mas também com o contexto e aparato tecnológico de cada época, Amaral apresentará a cibercultura de modo complexo.

A tentativa de refinamento do pensamento acerca dos fenômenos comunicacionais da cibercultura $[\ldots]$ leva em consideração três fatores básicos: primeiramente, a relação indissociável entre cultura e tecnologia, em um processo que vem em curso desde a modernidade; em segundo lugar, as intersecções homem-máquina em suas 
dimensões técnicas, sociais, antropológicas, econômicas etc. e, finalmente, a representação de um imaginário advindo dessas tecnologias digitais nos produtos midiáticos como filmes, quadrinhos, publicidade etc. (Amaral, p. 48)

Cultura e tecnologia estão, pelo autor, que não é só nesta fala, envolvidos e imbricados. Se trata da intersecção do homem-máquina como um dos grandes fatores do pensamento sobre a cibercultura, coloca em pauta e oferece à luz o tangível tanto maquínico desta conexão quanto humano, mas não se atreve, neste ponto, sequer a indicar uma predominância, além de referenciar uma palavra que já apareceu nesta obra algumas vezes e que será cara para algumas linhas futuras, a saber, o imaginário.

Já Silveira vai considerar que a cibercultura viria a ser uma classe menor da cultura, uma subcategoria, um degrau de nicho, focando em seu aspecto altamente técnico, a ver, a internet.

A cibercultura pode ser entendida como uma subcultura que nasce nas redes digitais e que desce do ciberespaço para os ambientes presenciais, influenciando cada vez mais as práticas sociais das diversas culturas cujos habitantes vão se conectando à Internet. (Silveira, p 81)

As palavras acima estão, assim, em grande oposição ao modo como Trivinho descreve não apenas a cibercultura, mas a dromocracia, a velocidade que há muito se desenvolve e se apresenta com as tecnologias de cada época.

Com efeito, é no estirão interativo da civilização mediática, nesse locus temporal do que a teoria da comunicação e a teoria social contemporâneas convencionaram chamar de cibercultura, que a velocidade acabou por ser erigida, propriamente, como regime tecnológico integral - como sistema social para usar um termo deslustrado -, de caráter transnacional, fincado desde as varandas até os porões dos sistemas políticos vigentes, não importa se monárquicos ou republicanos. (Trivinho, p. 21)

Vê-se que o autor indica a cibercultura como "regime tecnológico intergral", e como isso não distinguirá se o indivíduo que perpetua e emerge da cibercultura estará ou não conectado à internet ou a um aparelho em rede. Se a conexão direta lhe é falha ou não lhe interessa, a seus derivados não escapa.

Ainda que esteja apartado da eletricidade, o homem moderno não está livre de viver em uma sociedade elétrica. Da mesma forma, o sujeito contemporâneo não está em condições de esconder-se completamente da cibercultura em uma sociedade acelerada por seus imperativos.

Destaque-se, então, que o cibernético e o ciberespaço estão contidos, hoje, pela cibercultura, que não se resume a, mas que se nutre deles.

O universal da cibercultura não possui nem centro nem linha diretriz. É vazio, sem conteúdo particular. Ou antes, ele os aceita todos, pois se contenta em colocar em contato um ponto qualquer com qualquer outro, seja qual for a carga semântica das entidades relacionadas. (Lévy, 1999, p. 111) 
Importante, então, perceber que sem um centro, o controle da cibercultura é algo sempre hipotético, mas que em termos práticos é impraticável.

A organicidade das culturas é superada pela plasticidade da polimorfa cultura cibernética que, em Trivinho (2007) terá um grande nó górdio, a velocidade.

Objetivar o controle da cibercultura seria o mesmo que considerar e dominar tantas variáveis e fatores que sua efetivação é impossibilitada.

Mas se por um lado a cibercultura pode ser, como diz Lévy, vazia, sem uma linha mestra, esta tela branca está sendo vista pelos filtros, pelos enquadramentos de estruturas comerciais que estariam não gerando uma determinação da cultura, mas uma leitura hegemônica dos seus fragmentos infotécnicos, atuando no âmbito do mercado e da venda imediata, não se importando se estes enquadramentos estariam ou não enviesando a visão de mundo de seus usuários. “[...] concluímos, a cibercultura deve ser vista, sem espanto, como uma formação em que em vez do império da técnica ou da espontaneidade humana, o que predomina, como elemento articulador de suas experiências, é a forma mercadoria." (Rüdiger, p. 72)

Dentro de algumas páginas este ponto se fará mais claro. Porém é mister ter em mente que, como referenciado anteriormente, a tecnologia, a internet e (agora) a cibercultura não são em si boas, nem más, tão pouco neutras.

Se o ciberespaço aceitaria tudo e todos, pode ser que seja apenas para abarcar o todo, neste ímpeto universalizante indicado por Lévy, e para excluir novamente e fazer do substrato dos excluídos a força sustentadora da velocidade performática da obsolescência programada pela própria cibercultura. "A violência da velocidade se autojustifica pela transformação compulsória da dromoaptidão em imperativo categórico de época, válido para todos os setores sociais." (Trivinho, p. 97)

Dromoaptidão, então, em Trivinho, será a capacidade de responder à velocidade das trocas e atender e possuir as senhas infotécnicas para acessar os campos da cibercultura.

[...] códigos-senhas têm demandado e promovido uma célere reaculturação sem par das subjetividades e comportamentos, em prol da reprodução permanente das estruturas social-históricas e antropológicas da cibercultura. Vigorando como lastro de capital cognitivo a ser necessariamente dominado, sob a tutela da segregação infotecnológica, essa linguagem cumpre, em última instância, um desígnio social totalitário, subordinado à lógica de uma invisibilidade cotidiana que não concorre senão para mantê-lo intocado, no quadro metamórfico-dissuasivo da violência simbólica da técnica. (Trivinho, p. 137) 
De certa forma, a metáfora do espaço e do universal pode trazer um outro paralelo além daquele que fora citado anteriormente.

As fronteiras espaciais estão sendo fagocitadas pelo digital, fazendo desmoronar os empecilhos da digitalização, do monocódigo, de modo que o binário, a luz e sombra, estão sendo atraídos pela gravidade do ciberespaço, que não organiza, de per si, não cataloga, não rejeita, mas atrai tudo.

Devemos notar, entretanto, que a maximização dos elementos de código (normatização) não significa necessariamente maior probabilidade e precisão; as regras podem levar também a sistemas fechados, sem flexibilidade interpretativa, determinista. A abertura inferencial por sua vez, não significa necessariamente flexibilidade, espaço para a criatividade, democracia na participação; pode simplesmente reduzir a clareza, levar ao desentendimento ou produzir interações excessivamente dependentes do acaso. (Braga, p. 77)

Ao espelhar este pensamento, tem-se que mesmo que a comunicação digital traga estruturas tanto fortes quanto flexíveis, nem uma nem outra prevalece de modo a encerrar a outra.

O ciberespaço, em metáfora, vazio e repleto ao mesmo tempo, é o buraco negro, a zona de grande massa que estudamos, que tudo atrai, que nada rejeita, mas que, como antes, nada organiza. A convergência universal. Seu código permeará a sociedade, assim como já permeia.

Mas por convergência não se deve entender um processo silencioso e pacífico, diga-se de passagem, não só no aspecto técnico, como nos impactos sociais.

O termo convergência tem, na verdade, um inconveniente epistemológico. Ele destaca o ato de convergir, mas por um lado deve-se esquecer de onde vêm as correntes que convergem, e, por outro lado, ele tem uma conotação pacífica, como se esse fenômeno fosse tão tranquilo quanto uma figura geométrica... Se, em lugar de convergência, se falasse em "luta intermídias", sem dúvida veriam-se as coisas de outra maneira. (Jost, p. 94)

As mídias convergem pela linguagem digital mas não de modo silente. A violência silenciosa contra os corpos e mentes humanas também ocorre entre os meios de comunicação.

A cibercultura, como se verá mais adiante, legitimará a velocidade e sua violência sutil nos processos comunicativos e na coleta de dados e configuração da memória infotécnica. “Os regimes de legitimação operam, assim, tornando toleráveis ou desejáveis as práticas de vigilância." (Bruno, p. 36 - 37) Appelbaum trará o que chama de "os quatro cavaleiros do infoapocalipse: pornografia infantil, terrorismo, lavagem de dinheiro e a guerra contra certas drogas" (apud Assange, p. 64) justamente para indicar o discurso legitimador da vigilância 
que passa a ter um reflexo na sociedade que pede, através de um discurso esvaziado, a supervigilância sobre um crime que não enxerga.

Os algoritmos, frutos da mente humana em um primeiro momento, buscam encontrar uma causalidade e lógica neste caos, complexo, na busca de torná-lo inteligível às limitações fisiológicas e psicológicas dos seres humanos tanto para a publicidade quanto para a vigilância e escrutínio da bandeira de "segurança".

Então os filtros, as grandes corporações, estão ajudando a guiar certas percepções de mundo e a criação de significados compartilhados sobre o que está imerso na cibercultura, hoje, e nos espaços cíbridos do presente e do futuro, mas não possuem a capacidade completa da ciberexclusão, do ostracismo, do aniquilamento da alteridade. "A cibercultura é fractal. Cada um de seus subconjuntos deixa aparecer uma forma semelhante à de sua configuração global.” (Lévy, 1999, p. 142)

Ou seja, a dinâmica permissiva da cibercultura aparecerá até nos cenários mais restritos, como a resistência civil e ilegal dos chineses às regras e restrições impostas em seu país para o acesso a determinados sites na internet ao mesmo tempo que poderá se apresentar de modo constante, mantendo sua plasticidade, mas garantindo sua redundância.

A passagem levyniana é uma constatação de um dos maiores defensores da cibercultura, que percebe sua característica fractal, mas que a este tempo não pôde antever a possibilidade de encontrar e monitorar cada passo do grande amálgama.

Claro, havendo subterfúgios e resistências, mas em uma cultura que está a cada dia mais recriminando aquele que se esquiva das áreas "públicas" do ciberespaço, relegando a todos os resistentes a pecha de cibercriminosos, pedófilos, pervertidos.

A escória da internet, para muitos, é aquele que não está visível, que não está público, que está a se esconder. Proteger seus dados deixou, em poucos anos, de ser prudência e se tornou dívida, atestado de culpa, receio, crime social.

Se, por um lado, Lévy indica a potencialização intelectual da humanidade com base nos desenvolvimentos da cibercultura, em outros ele já traz alguns itens, como o aparato que dá origem à paramemória, a memória de suporte, a memória externa, que será mais adiante tratada.

Entre os novos modos de conhecimento trazidos pela cibercultura, a simulação ocupa um lugar central. Em uma palavra, trata-se de uma tecnologia intelectual que amplifica a imaginação individual (aumento de inteligência) e permite aos grupos que compartilhem, negociem e refinem modelos mentais comuns, qualquer que seja 
a complexidade deles (aumento da inteligência coletiva). Para aumentar e transformar determinadas capacidades cognitivas humanas (a memória, o cálculo, o raciocínio especialista), a informática exterioriza parcialmente essas faculdades em suportes digitais. Ora, uma vez que esses processos cognitivos tenham sido exteriorizados e reificados, tornam-se compartilháveis e assim reforçam os processos de inteligência coletiva... se as técnicas forem utilizadas com discernimento. (Lévy, 1999, p. 165)

Já em 1996, o próprio autor trará uma constatação que segue válida nestas duas décadas. "Nossa espécie lançou-se sem retorno nesse novo espaço informacional. A questão portanto não é avaliar sua 'utilidade' mas determinar em que direção prosseguir um processo de criação cultural irreversível.” (Lévy, 1996, p. 86)

Ou seja, mesmo em Lévy, um dos maiores defensores da cibercultura, há as linhas que indicam a mesma questão levantada anteriormente por Hilton. É preciso que a humanidade tome para si a tarefa de definir os caminhos pelos quais seguirá, não se abandonando aos ventos da cibernética com deslumbre extasiante.

Antecipando brevemente a questão da vigilância, enquanto Lévy fala dos benefícios da rede colaborativa e da consciência coletiva, Fava dirá que por mais autônomo que se pense um indivíduo dentro do ciberespaço, "o que se faz presente em toda parte, o que sabe tudo, o verdadeiro 'deus' do ciberespaço não é o usuário, mas sim as tecnologias de vigilância digital." (Fava, p. 12)

O espaço digital é o espaço dos dados, e com isso, da extrema vigilância.

Em consonância, praticamente Foucault parece falar pelas palavras de Schönberger no momento em que este indica que

\begin{abstract}
If we had to worry that any information about us would be remembered for longer than we live, would we still express our views on matters of trivial gossip, share personal experiences, make various political comments, or would we self-censor? The chilling effect of perfect memory alters our behavior. (Mayer-Schönberger, p.5)
\end{abstract}

Logo se tratará destas características de vigilância e autovigilância, mas este processo não está estanque. Quando Santaella passa a indicar o processo de aprendizado da tecnologia focada em desenvolver a própria tecnologia, ela se depara com uma questão crucial sobre a miscigenação entre o corpo orgânico e o inorgânico, ainda que em sua obra de 2004 não estava acentuada plenamente a sua visão sobre como as tecnologias de então, e as de uma década à frente, estariam integradas de modo ainda mais subjetivo às formas de compreensão do próprio indivíduo.

O mais impressionante nessa transformação encontra-se no gato de que ela chegou ao limite, como já vimos, de produzir uma mutação no próprio estatuto dos corpos vivos. A mistura crescente entre o vivo e o não-vivo, o natural e o artificial, 
permitida pelas tecnologias, atinge hoje um tal limiar de ruptura que faz explodir a própria ontologia do vivo. (Santaella, 2004, p. 31)

Assim, a tecnologia está posta na ecologia dinâmica da cultura cibernética de tal modo que afeta os corpos e as mentes, num questionamento que se pauta, ainda nos dias atuais, sobre o vivo e o não-vivo, mas que em realidade está sobre a citada mão invisível smithiana, ou talvez do capital, da velocidade. "[...] a dinâmica econômica é de fato proposta como explicação necessária, e também suficiente, para compreender o processo dos efeitos culturais-ideológicos da mídia." (Wolf, p. 103)

Da mesma foram, o rumo social está atrelado aos caminhos da tecnologia e do sujeito. Em dúvida está quem é o agente factual das transformações da sociedade contemporânea, mas como no trecho acima, já não se separa muito bem a tecnologia do sujeito.

Da mesma forma, a tecnologia que participa da ação cultural do sujeito contemporâneo é também a tecnologia da vigilância e, de certa forma, de controle.

Então a reflexão dirá que uma possível dicotomia é se o sujeito e a tecnologia, juntos, estão caminhando em um rumo traçado por algo diferente de ambos ou que deriva de sua interação.

Uma forma de condensar o exposto até agora será vista nas falas de Trivinho.

[...] a maioria dos valores sociais e culturais comparecem, por pressuposto, significativamente transformados, alguns inteiramente irreconhecíveis, conforme se expressam na relação com o tempo e com o espaço, com o urbano e com o social, com as culturas locais e transnacionais, com o corpo, com a identidade e com a alteridade: ao passo que a história se hiperacelera, a violência da técnica se estiliza e se sutiliza; se a semiose social se digitaliza, o signo se esvazia (um pouco mais) do significado. (Trivinho, p. 25)

Dá, o autor, o destaque à transformação dos valores sociais a um ponto em que alguns chegam a ser irreconhecíveis pelo cidadão médio, e o exemplo mais direto é o esfacelamento do que antes era tido como espaço privado, com a evasão da privacidade através de um imperativo de invasão e pervasão da cibercultura.

Cabe recorrer a La Boétie, que em sua obra "A servidão Voluntária", ao tratar sobre os tiranos que governam do povo, muito disse também das formas de governo, de controle, e aqui caberá, também, a cibernética em seu radical controlador kubernetes.

Para ele, ao falar de quem lucra ao lado do poder, dirá que estes, "muitas vezes enriquecidos à sombra de seu favor com os despojos alheios, no fim o enriqueceram eles mesmos com seus próprios despojos." (La Boétie, p. 68) Então a evasão da privacidade nas redes da cibercultura, aceleradas, com o argumento do conforto e da praticidade será, em certa 
medida, um enriquecimento com os próprios despojos, alimento da antropofagia cibernética. “[...] parece natural ser bom em relação àquele que nos proporcionou o bem e não temer mal algum da parte dele.” (La Boétie, p. 33) Isso acaba sendo similar à aceitação que se tem tácita, ou mesmo festejada, em alguns casos, na entrega de dados a redes de conteúdo que mal explicam os usos que se farão de cada informação coletada.

Isso serve não só para a tecnologia como um todo, mas também para os governos e empresas, pois sem a condução legal, todos estão desprovidos dos limites claros e baseados na tergiversação ética dos operadores sem que os caminhos fiquem claros tanto quanto os riscos atrelados a eles.

Todos os nossos rastros são registrados e armazenados em algum lugar da rede, mas aparentemente para a maioria isso não tem importância, uma vez que as pessoas estão tão satisfeitas com o que as empresas oferecem que desconsideram as implicações decorrentes. (Santos e Nicolau, p. 9)

O mandatório é estar no espaço público cibercultural, estar exposto, estar publicado, mensurável. Oferecer-se. Entregar-se. Diluir-se para sorver o gosto do que é exposto, pois o consumo privado é o consumo da clausura frente à ordem dromocrática. Um exemplo prático está na demissão de Myrna Arias após ter desinstalado de seu celular um aplicativo chamado Xora que rastreava todos os passos de cada funcionário da Intermex Wire Transfer ${ }^{4}$.

O que a máquina permitirá simplificar e tornar mais direto e transparente, de um lado, será ao contrário mais regrado, mais fechado, mais codificado de outro. Os sociólogos demonstram isso muito bem: quanto mais há transparência, mais há rumores e segredos. Tão simplesmente porque nunca há relações sociais transparentes. (Wolton, p. 103)

A mão que simplifica é a mesma que castra. Não há amputação de processos, de mazelas, sem que a carne fresca sofra o mesmo corte. "A teoria dos processos de comparação social postula que 'quem se assemelha, se une'. E se a semelhança é fraca num primeiro tempo, ela deve acentuar-se no decorrer do tempo." (Deschamps, p. 43)

Quando a tecnologia e a cibernética aceleram e simplificam os processos dialógicos, estão também a afastar o sujeito do embate necessário para fortalecer seus músculos sociais, éticos e morais.

Sem este encontro reativo, o espaço entre os repertórios e sujeitos se tornam lacunas ainda mais difíceis. Sem andar com as próprias pernas, o homem pode deixar de visitar

\footnotetext{
${ }^{4}$ Funcionária é demitida após desinstalar app que a rastreava 24h por diaFuncionária é demitida após desinstalar app que a rastreava $24 \mathrm{~h}$ por dia . Disponível em <http://www.tecmundo.com.br/privacidade/79768-funcionariademitida-desinstalar-app-rastreava-24h-dia.htm>. Acesso em 20 de maio de 2015.
} 
terrenos tortuosos e perder sua pujança adaptativa, sendo dependente da tecnologia futura para levá-lo de volta ao ponto do qual ela o ajudou a sair.

Se o ciberespaço é o local, neste mesmo sentido, a cibercultura é a velocidade. O tempo, nesta aritmética, está encerrado no presenteísmo confortável das redes contemporâneas.

O terreno dos embates, em meio ao diálogo aberto e com concordâncias e discordâncias é um exercício necessário. A atrofia das múltiplas visões de mundo traz consigo o aprisionamento do sujeito em um universo autorreferente, alérgico a corpos estranhos, frágil a outro, à alteridade. "Tapan Bhat, $[e x]$ vice-presidente do Yahoo, concorda: "O futuro da internet é a personalização - a rede agora gira em torno do 'eu'." (Pariser, p. 13) Mas é papel da academia e da sociedade se perguntar que "eu" é este ao qual se refere Bhat, conquanto as tecnologias de dados passam não a incrementar, pura e simplesmente em uma soma, a ecologia das mídias, mas transforma não apenas esta, como também a sociedade de modo coletivo, e os sujeitos de modo individual. Os impactos sociais das tecnologias de filtros poderia até ser rotulada por alguns de egocêntrica, mas que "ego" é este, e que "centro" se pretende ter em tempos de dados recursivamente presentificados por redes de bancos de dados.

Se verá, dentro das próximas páginas como a aceleração, velocidade e seu reflexo violento acabam por pressionar e abalar a alteridade.

[...] ligação entre processo sociotécnico de fomento da velocidade e processo histórico permanente de destruição material e/ou simbólica da alteridade, de seu grupo ou classe social, de sua urbis, de seu ecossistema e de sua cultura; em suma, de sua alma. (Trivinho, p. 46 - 47)

O impacto infotécnico está, então, não apenas no ritmo, na cadência social, mas em sua ecologia como um todo.

Tecnologia, produto da mente humana, para se prolongar como informação memética, talvez, está na raiz do homem extirpado do estado de natureza, a princípio pela sua primeira grande tecnologia, a linguagem, e a posteriori por todas as suas derivadas e técnicas.

Estas linhas não estão evocando o determinismo tecnocêntrico do homem, mas chama às veias o furor de lutar para ter parte nos caminhos que se traçam sob seus pés. Assim, o próprio Wolton virá para indicar o espaço de criação do sujeito, conflituoso, complicante, defeituoso e, por isso, criador.

É claro que a vida privada não está "de lado", ela é em boa parte determinada pela realidade econômica, o tempo de trabalho, a educação, o modo de viver... mas ela 
não se reduz a esse conjunto de variantes. Subsiste um espaço onde cada um fabrica sua liberdade. Os novos serviços, seguindo a linha de pensamento do vasto movimento de socialização, implicam uma penetração em todos os espaços da vida. Pode-se e deve-se racionalizar o fantástico bazar da vida privada? (Wolton, p. 102)

Ao desconstruir o conceito de privacidade, há também o impacto sobre o que é o espaço público. Mesmo que não seja o foco desta obra, é válido destacar, que na medida em que o contraste entre público e privado se atenua, a cultura digital e cibernética não estaria desconstruindo apenas o muro que separa ambos os conceitos, mas as práticas que os caracteriza.

\begin{abstract}
O campo da visão é unidirecional: a pessoa que vê pode observar os outros que estão distantes dela sendo filmados ou fotografadas ou representados de alguma forma, mas estes não podem, na maior parte dos casos, vê-la. Assim, o desenvolvimento das mídias comunicacionais acabou por gerar uma nova forma de visibilidade - ou, para ser mais preciso, novas formas de visibilidade cujas propriedades específicas são moldadas por meios específicos de comunicação. O que entendemos como esfera pública hoje é essencialmente e indiscutivelmente constituído por essas novas formas de visibilidade mediada - é, em outras palavras, uma publicidade mediada. Isso não quer dizer que essa seja a única forma de publicidade existente hoje. (Thompson, p. 21)
\end{abstract}

Assim, o espaço público, espaço no qual os itens de interesse coletivo e difusos são tratados para o bem social agora está inundado de conteúdos, dados, informações espetaculares sobre a vida cotidiana de pessoas comuns, mas que não impacta apenas a publicidade e os campos que podem ser aparentemente mais ligados à comunicação imagética, mas a sociedade de modo geral que está inserida e inscrita no campo da visibilidade cibercultural.

Nota-se, também, com este alagamento dos espaços públicos com os conteúdos espasmódicos da comunicação individualizada, que o próprio jornalismo acaba por sofrer golpes significativos, estando, nos dias atuais, em uma zona indeterminada na qual parte dos profissionais busca oferecer resistência com matérias investigativas de fôlego, mas parte se dobra aos imperativos da agilidade da cibercultura e serve ao capital simbólico performático.

De qualquer modo, ambos os polos passaram a disputar espaço, relevância, entre produtos midiáticos em fluxo contínuo e, novamente, produzidos de modo espasmódico, em muitos casos.

Este é um dos resultados do que Trivinho indicou como sendo "[...] a inserção, na cultura, do espectro eletromagnético como oceano dromológico invisível de fluxos simbólicos e imaginários." (Trivinho, p. 55) Em palavras comuns, é a cibercultura, em seu imperativo de aceleração das trocas simbólicas, que está encharcando as bases da sociedade contemporânea. 
Então, ao estudar o território de poder que é conhecido por ciberespaço, lembrando que este ainda remete, em muitos casos, a uma estrutura espacial digital, mas para os efeitos deste estudo, são os espaços cíbridos, na medida em que as tecnologias vestíveis deslocaram o ciberespaço da primazia do virtual para a relação íntima entre todos os espaços e a camada de dados disponível em rede, e há de se compreender também que o espaço está em relação direta com os sujeitos e com os grupos, com a sociedade.

[...] a alma coletiva tende a prevalecer contra o espírito individual. De várias maneiras mostramos a estreita relação existente entre o racionalismo cartesiano e o logocentrismo dele resultante. Esse 'eu penso' soberano constitutivo de si e do mundo, que produz a sociedade parece inundado por uma explosão de prazer e gozo. A exacerbação do corpo individual no âmbito de um corpo coletivo remete a outra forma de laço social com ênfase lococêntrica. É o local, o espaço, que prevalece. Espaço do próprio corpo trabalhado à vontade, vestido para a oração, enfeitado para o prazer, mutilado para ou por um gozo doloroso. [...] Com frequência, tenho mostrado esse deslizamento do logocentrismo para o lococentrismo, lembrando que em certas épocas o local faz laço. (Maffesoli, p. 254)

Desta forma, se o local faz o laço, e tendo a cibercultura sem um centro definido, o lococentrismo poderá estar atrelado ao locus do ciberespaço que, em si, não está ancorado no espaço físico, mas no tempo. O ciberespaço, polimórfico, se constitui pelo fluxo acelerado de informação. Assim, conquanto em 2006 Maffesoli indica a prevalência do espaço, com Trivinho prevalecerá o tempo, o ágil, o veloz.

Se houve inversão, como se verá, no custo de memória e esquecimento, houve também a inversão da relevância do local para o tempo, do espaço para o tempo no espaço, e este tempo foi acelerado e comprimido.

Por certo, a realização per se, numa importante esfera social específica, do princípio dromocrático subsumido no ideal da produtividade industrial teve como resultado difuso e inespecífico a aceleração da vida humana. Com efeito, a expansão desse valor, em forma de pressão social concreta, para a esfera do tempo livre e de lazer não teria sido possível sem o concurso exponencial de outro vetor processual, a comunicação em tempo real, cujo advento e desenvolvimento, na primeira metade do século XX, alterou significativamente as bases sociais e culturais em que a vida humana - até então centrada absolutamente em contextos presenciais, in loco estava assentada. (Trivinho, p. 62-63)

O princípio dromocrático, que está resumido na velocidade e será melhor trabalhado adiante, foi posto, então, pelo autor, em uma perspectiva de aceleração e pressão social sobre o tempo livre, o tempo do trabalho, o tempo da produção, o tempo do lazer.

[O] artifício dos tiranos para embrutecer seus súditos nunca foi mais evidente que no procedimento de Ciro em relação aos lídios [...]. Estabeleceu ali bordéis, tavernas e jogos públicos, e mandou publicar um decreto ao qual os habitantes tiveram de obedecer. Ficou tão satisfeito com essas medidas que, dali por diante, não fio mais preciso desembainhar a espada contra os lídios. Essa gente pobre e miserável se divertiu inventando todos os tipos de jogos, a tal ponto que os latinos tiraram deles a sua palavra. E que nós chamamos passatempo. Eles a chamam ludi [...]. (La Boétie, p. $55-56)$ 
Até no momento de lazer está, cada indivíduo, produzindo valor e respondendo ao imperativo dromocrático, ou seja, de velocidade cibercultural.

Para Felinto, nesta consonância sobre velocidade e impacto da cibercultura na história, há de se perceber que "na cibercultura, o culto ao novo equivale a uma espécie de sequestro da história, que impede uma percepção adequada das contradições e dos fluxos heterogêneos que atravessam a dinâmica tecnológica.” (Felinto, p. 43)

\subsection{DROMOCRACIA E VELOCIDADE}

Esta relação da cibercultura com o tempo, e com isso, com a velocidade, está destacada no trabalho de Trivinho. Destaca-se também que esta aceleração fora possível apenas com o vetor comunicacional também acelerado. Quando Trivinho indica a comunicação em tempo real está a dizer o tempo do ao-mesmo-tempo. O tempo do entre-máquinas, o tempo que ilude a inexistência de um intervalo.

Em Felinto, isso será posto como

Se um dos temas mais pregnantes da cibercultura é a ideia de real time, isso possivelmente aponta para um desejo de presenteísmo total que está no coração do imaginário cibercultural. Em tempo real significa aquilo que acontece sem diferença temporal, sem intervalo. Levada a seu paroxismo, tal expressão implica um punctus temporal absoluto, desprovido de dimensão, extensão e história. (Felinto, p. 50 - 51)

Já em Trivinho, este debate da velocidade terá ainda, e novamente, mais um desdobramento.

Se, por um lado, a velocidade na esfera do trabalho responde, numa epistème alternativa, pelo que se entende correntemente por produtividade, escala dromológica do valor medida pela maior produção material em menor tempo possível, por outro, a velocidade na esfera do tempo livre chama-se intensidade, escala dromológica do ludismo medida pelo maior aproveitamento das atividades de lazer no menor período de tempo possível. (Trivinho, p.92)

O tempo como intervalo some na velocidade da comunicação.

O espaço da cibercultura é cíbrido, é o ciberespaço atrelado à vida humana e ao complexo maquínico, e agora, o tempo da cibercultura é o "tempo real", o tempo-agora, lembrando que a cibercultura é a velocidade viriliana. E sem o distanciamento referencial do tempo, o tempo-agora se torna não-tempo, convertendo em obsoleto o tempo cursivo, o tempo corrente, o tempo reflexivo, comparativo. "A ideia de que 'tudo' está disponível a apenas um clique, de que não há mais fronteiras espaciais e temporais e de que é possível estar em qualquer lugar, a qualquer momento, ganha novos contornos ao pensarmos o ciberespaço". (Fava, p. 1) 
Palácios vai dizer que "com as redes telemáticas - e a Web em particular - a continuidade do fluxo se completa, estabelecendo, de modo definitivo, a midiavivência da vida em tempo real. (Palácios, p. 42)

O tempo do agora eterno é o tempo da velocidade da comunicação, da resposta agora, do instante fugaz e recorrente.

Nesta produção ininterrupta em um fluxo comunicacional, a acreditada revolução digital está a conquistar terrenos de modo bárbaro, devastando as terras, por vezes, para lançar suas sementes profundas.

[...] o sentido da revolução permanente; a ideia de que não basta ser novo: é necessário fazer política de terra arrasada com o passado. Finalmente, a exaltação da novidade por meio de um neologismo sonoro e sedutor. Não importa que o sujeito não saiba o significado de wikinomics. O termo é atraente, imponente, vanguardeiro (trendy). Só pode mesmo tratar-se de algo muito importante! Movemo-nos aqui em um terriório no qual o sentido é menos importante que a produção de afeto. (Felinto, p. 45)

A comunicação na dromocracia cibercultural estaria então mais ligada ao tempo, à velocidade, do que necessariamente ao seu conteúdo, tornando o igual, o recorrente em algo obsoleto, e o novo em algo especial, gérmen de nova aceleração, de nova exclusão também, diga-se de passagem.

[...] a velocidade de transformação é em si mesma uma constante - paradoxal - da cibercultura. Ela explica parcialmente a sensação de impacto, de exterioridade, de estranheza que nos toma sempre que tentamos apreender o movimento contemporâneo das técnicas. (Lévy - cultura, p. 27)

Se em Lévy, no final do último século, havia ainda um paradoxo que tornava a cibercultura algo de compreensão dificultosa, em 2007 Trivinho já estava atento a uma das suas características mais marcantes.

Enquanto em Lévy a cibercultura é universalizante sem ser totalizante, em Trivinho ela é violenta e ágil. E a agilidade vai caracterizar todas as interações, conexões e trocas sociotécnicas, ou seja, as trocas sociais que passam pela cultura cibernética e que estão indissociáveis da técnica e da, agora sim, universalização do código de trocas e comunicação da cibercultura, o digital, o binário.

Conquanto a expressão da sociedade de comunicação de massas para aquilo que se consideraria verdadeiro, de certo modo, relembra a imprensa e a escrita, ou seja, o confiável é o "preto no branco", a tinta, a letra, a palavra gravada e difundida, na cibercultura esta solidez causará estranhamento e repulsa. 
O ágil, mutante é o crível. Efemeramente crível. Basta por este instante, não pode bastar por muitos instantes mais.

Lévy será enfático: "resumindo, a cibercultura dá forma a um novo tipo de universal: o universal sem totalidade." (Lévy - cultura, p. 119). Mas se ela não é totalitária no conteúdo ou em seu centro, ela o é em sua violência atrelada à velocidade. Enquanto Lévy agita a flâmula da tecnologia que pode libertar, Trivilho soa a sirene da exclusão e do imperativo violento altamente sutilizado.

[...] a dromocracia se tornou, mais do que tudo, a lógica exponencial específica da cibercultura. Dito de maneira inversa, a cibercultura, em sua natureza, dinâmica mundial e consequências, se apresenta como uma sociodromocracia tecnológica em sua forma mais definida e irradiada. Em miúdos, se a dromocracia é o reino da velocidade e se a cibercultura como categoria de época (substituta do conceito de sociedade) é o reino do interativo e do virtual, a dromocracia cibercultural equivale ao processo civilizatório longitudinal fundado na e articulado pelo usufruto diuturno da velocidade digital em todos os setores da experiência humana, horizonte no qual e a partir do qual a união inextricável entre comunicação, vetor dromocrático e cultura é realizada pelo processo aleatório, via mercado, da informatização, virtualização e ciberespacialização como indexador prioritário da experiência de mundo. (Trivinho, p. 23)

O autor oferece de modo profundo a percepção de que a velocidade, nos parâmetros contemporâneos, está no cerne da cibercultura na medida que esta se encontra com a comunicação, mas também indica a relação atual do mercado neste processo, bem como dos aparatos infotécnicos.

Foque-se, então, que dentro da cibercultura, os contornos são redefinidos independentemente do viés moral. Esta aceleração, este tempo real ou irreal não está pautado por moralismos, moral ou éticas. Wiener dirá que "o progresso não só impõe novas possibilidades para o futuro como também novas restrições” (Wiener, p. 46).

Em meados do século passado, o autor pensava no que viria a ser o resultado da cibernética na sociedade, mas o complemento a sua frase é que o progresso não impõe novas possibilidades para o presente, como o reinventa e, assim, transforma o futuro, oferecendo oportunidades e restrições imanentes.

Ao pensar nesta possibilidade de restrições, não apenas de desenvolvimentos positivos. É relevante resgatar o questionamento de Palácios que, ao lançar seus olhares sobre o campo jornalístico, acaba por topar com pontos nevrálgicos da contemporaneidade.

Em tempos líquidos, nos quais importa velocidade e não duração, onde fica a Memória? Em uma contemporaneidade caracterizada como presente contínuo, não estaria o jornalismo, mais que nunca, condenado a ser a crônica de uma Atualidade para a qual importa pouco ou nada o passado e para a qual o futuro, quando existe, passa a ser uma questão de fazer render o Acontecimento, transmutado em Notícia, 
até quando possa durar o interesse público e até quando possam ser mantidos em alta os índices de audiência? (Palácios, p. 38)

Este questionamento se colocará de modo latente e pulsante ao longo desta obra não para o jornalismo, mas para as estruturas de tecnológicas que, na mesma medida que impacta o jornalismo que faz render o acontecimento, o faz também na vida cotidiana midiatizada.

Longe dos discursos ufanísticos da tecnologia benevolente ou libertária, está dado por Wiener o aspecto contrastante de todo avanço tecnológico.

Todos os benefícios à vida contemporânea trazidos pela tecnologia digital nos dias atuais não redimem, em mesma medida, seus aspectos restritivos e limitantes. Esta não é uma aritmética simples na qual os benefícios são calculados e contrapostos aos riscos ou máculas. Cada fator tem sua dor e seu prazer.

Se a alegação é a emancipação do receptor que vem a se tornar um emissor de conteúdo, ou mesmo o prossumidor, ou seja, produtor e consumidor dos conteúdos, faz-se necessário destacar que "[...] embora a submissão aos mediadores seja um problema real, a história da desintermediação tem uma boa dose de mitologia. Seu verdadeiro efeito é tornar os novos mediadores invisíveis." (Pariser, p. 58, grifo nosso) Em outras palavras, se agora os meios de comunicação de massas já não são os curadores principais da notícia e da comunicação, há de se recordar que tão pouco ainda o é o indivíduo que produz e tenta disseminar sua visão de mundo. Assim, dizer apenas que a rede pode multiplicar vozes não pressupõe uma melhora na condição de vida humana, sendo que sequer pressupõe o real empoderamento sobre as redes.

"[...] before [year] 2000 it was a tool [the internet] to access information, today it is also a tool to share information. This implies a shift from passive recipient to active contributor, quite similar to what digitization has done for producing and consuming information itself." (Mayer-Schönberger, p. 85)

Ainda com foco nesta questão, mesmo que haja uma polifonia nas redes, estaria a mesma sob os domínios, contemporaneamente, tanto da cibercultura quanto da dromoaptidão mandatória, imperativa.

Assim, vozes vigiadas, vozes monitoradas e medidas são vozes monitoradas e medidas. Por mais infantil ou mesmo redundante que possa ser esta frase, ela deflagra a contaminação dos indivíduos e de suas comunicações pelos aspectos sociotécnicos vigentes e dromocraticamente aceitos. O duplipensar de George Orwell estará presente a cada vigilância percebida ou imaginada. As bandeiras antigas da libertação do homem laboral, substituído pela máquina poderia estar empoderada nas prateleiras de décadas atrás, não fosse pelo 
discurso recorrente de que este ideal ainda será cumprido. Se não de modo direto e claro, de modo velado e sutil, este discurso é perpetuado.

"[...] qualquer pessoa que seja 'olhada' por um usuário de Google Glass pode estar sendo filmada ou fotografada sem perceber. Ainda, o fato de os computadores vestíveis estarem constantemente conectados à internet geram preocupações sobre um possível rastreio remoto de localização geográfica e exposição de dados pessoais, além do medo constante de hacking e de violação do anonimato." (Corso, p. 2)

Diferentemente das fotos divulgadas da atriz Carolina Dieckmann, das quais ela tinha conhecimento, e depois acabaram roubadas e publicadas, a preocupação da autora encontra eco na prática de invasão dos notebooks mais atuais, que munidos com câmeras, passam a transmitir as imagens de dentro da empresa, casa, quarto, banheiro, de onde quer que o usuário esteja e sem sequer que ele saiba que há um material imagético sendo produzido e distribuído consigo em primeiro plano.

Um caso direto desta prática está na matéria publicada no Canaltech que se baseou em um levantamento da BBC em 2013, quando os jornalistas se depararam com um jovem finlandês de 17 anos que já havia invadido mais de 500 câmeras e vendido conteúdo e também o vírus para pessoas interessadas em seguir a mesma prática. ${ }^{5}$

Ainda que o tema da vigilância tenha suas próprias páginas futuras, este tópico inicial está apresentado para ajudar a compreender que dentro da cibercultura que exige agilidade e aceleração, não há tempo para se pensar que tipo de informação precisará receber maior proteção e qual poderá ser deixada a sua sorte na rede. Se a agilidade pauta a comunicação e as respostas na cibercultura, não se pode dizer o mesmo sobre o raciocínio demorado e profundo sobre os impactos presentes e futuros das manifestação de opinião que se faz no instante.

$\mathrm{Na}$ atualidade, a velocidade encontra-se materializada no próprio aparato produtivo, em sua dinâmica interna, em sua lógica operacional, em suas necessidades de reprodução infinita, de maneira que ela recai, em maior ou menor medida, como violência - que ela sempre foi, por seus vínculos originais com o campo da guerra -, sobre os ombros de todos os contemporâneos, indistintamente. (Trivinho, p. 91)

Em guerra, então, não está apenas o combatente, o soldado, o exército, mas está em aceleração bélica o indivíduo que dispara contra o ostracismo e para marcar seu lugar entre os dromoaptos. Respondendo aos impulsos e estímulos, abre sua casa e sua vida para que suas

\footnotetext{
${ }^{5}$ Cuidado: sua webcam pode estar sendo controlada por hackers. Disponível em: $<$ http://canaltech.com.br/noticia/seguranca/Instituicao-adverte-para-os-perigos-de-webcams-invadidas-porhackers/>. Acesso em 16 de junho de 2015.
} 
informações sirvam de nutrientes para alimentar sua integração social, para lubrificar as engrenagens do grupo, do pertencimento como logo se verá.

\subsection{DROMOAPTIDÃO E EXCLUSÃO CIBERCULTURAL}

De pronto, na cibercultura veloz, na cibercultura dromocrática, não há sujeito que seja dromoapto, mas sim aqueles que estão dromoaptos de acordo com o contexto e condições momentâneas.

Não há lugar de privilégios ou destaque no corpo cibernético, se não o papel comunicante e perpetuador do movimento e da retroalimentação. A barreira ao fluxo comunicativo é um erro, é entropia que todo o sistema buscará combater com a redundância, com a repetição constante e contínua.

Mas não se deve considerar a dromoaptidão como exclusividade da cibercultura.

[...] a capacidade dromoapta - a propensão treinada ao ser mais e mais veloz sempre marcou, para além do bem e do mal, no nível do processo social-histórico, a superioridade e as prerrogativas de impérios, Estados, capitais, instituições, clãs, castas, classes, oligarquias e indivíduos. Na fase atual do capitalismo tecnológico, $a$ dromocracia, na base de tantos recursos e fatores mediáticos disponíveis, se arranja, distintamente, como regime pantópico da velocidade interativa, traduzindo em pressões sociais provenientes de todas as partes e de lugar nenhum, que organizam, de maneira consuetudinária, silenciosa e implacável, o social e a cultura contemporâneos. (Trivinho, p. 24)

Estar apto, nestes casos, é ser capaz de responder no instante aos clamores técnicos das estruturas de comunicação e cultura de sua época. Se é possível perceber a angústia humana aflorando com maior intensidade na transição da modernidade para qualquer de suas novas expressões, entre elas, a hipermodernidade debordiana, representada pela velocidade acelerada, o mesmo se viu ao longo do tempo em cada um dos processos de ruptura e transição do passado, e mais evidentemente na passagem das ditas trevas para o iluminismo burguês e do iluminismo para a modernidade.

Em resumo, a aceleração seta sendo incrementada, mas não é um processo exclusivo dos dias atuais. E na mesma medida que sempre fez parte das sociedades humanas, das guerras, das disputas, do confronto, o fez através da balança tirana da aptidão, da inclusão e da exclusão, seguindo com sua foice a cortar e extirpar dos grupos aqueles que não estão em consonância, em ritmo de acompanhar os mesmos passos da tecnologia e dos seus colegas, cocidadãos dromoaptos.

É sob a cláusula da dromoinaptidão que gravitam e se legitimam os traços de uma nova forma tecnológica de estigmatização da alteridade. A finalidade é clara, 
presente em todo substrato bélico de relação social: o outro é estereotipado para ser, obviamente, rechaçado, quer dizer, simbolicamente morto. (Trivinho, p. 107)

A legitimação não está, então, no poder aquisitivo, em si, mas em poder, em ser capaz de seguir os caminhos e as velocidades tecnológicas para manter a comunicação sem restringir os movimentos do corpo cibernético, da máquina, do ciborgue.

O estereótipo está posto para a, da mesma forma, rápida compreensão e possível exclusão veloz daquele que não lhe segue os passos em mesmo compasso.

Antever o sujeito e classificá-lo de acordo com sua habilidade instantânea de responder ao imperativo da velocidade se liga à angústia de ter que estar apto a cada instante, em cada relação, em cada diálogo e interação, já que tal exclusão não se faz no futuro, mas sim no passado.

Logo será visto que tal aptidão estará marcada em um imperativo de pretéritos presentificados. O passado, impedido de morrer, será a carne de Prometeu, a ser ferida diariamente e reformada a cada noite de sono para que possa ser violada novamente a cada instante possível.

Neste imperativo da aptidão técnica e veloz, o objetivo é tanto ser um interlocutor aceito, ser parte, sentir a pertença de um grupo quanto fazer parte da própria tecnologia.

Como estar em sociedade sem estar em grupo e atender às regras postas na dinâmica de poder?

\begin{abstract}
A lógica que regula os fenômenos sociais é constituída pelas relações de funcionalidade que dirigem a solução de quatro problemas fundamentais, ou imperativos funcionais, os quais todo sistema social deve fazer frente: 1. a conservação do modelo e o controle das tensões [...]; 2. a adaptação ao ambiente $[\ldots]$; 3. a tentativa de atingir o objetivo [...]; 4. a integração [...]. Quando se observa que a estrutura social resolve os problemas relacionados aos imperativos funcionais, a intenção é dizer que a ação social em conformidade com as normas e os valores sociais contribui para a satisfação das necessidades do sistema. (Wolf, p. $52-53$, grifo nosso)
\end{abstract}

O sistema, a tecnologia, e, em si, a cibercultura terão suas demandas, não como sujeitos conscientes e autônomos, mas como estrutura pervasiva e reproduzida por seus constituintes, os grupos humanos.

Assim, conquanto haja as necessidades do sistema social, este está, nos dias atuais, sendo apresentado pelos contornos da cibercultura, e ao ter isso em vista, então as necessidades citadas, trazidas ao novo milênio, são as necessidades mesmas presentes na obra de Trivinho (2007), relacionadas à velocidade, aceleração e seu imperativo. 
A dromoaptidão é requisitada como condição indispensável para a constituição dos processos comunicacionais e, na mesma lide, dos processo sociais.

Não diferente, então, em Lazarsffeld-Merton (apud Wolf), a disfunção narcotizante se apresenta como atenuante das dores e da percepção do indivíduo que está a se abster de ir a fundo em todas as questões principais sobre a influência das novas tecnologias sobre a constituição de seu eu.

O cidadão interessado e informado pode sentir-se satisfeito com tudo o que sabe, sem se dar conta de que se abstém de decidir e de agir. Em suma, ele considera o seu contato mediato com o mundo da realidade política, da leitura, $\mathrm{o}$ ato de ouvir o rádio e a reflexão como um sucedâneo da ação. (Lazarsfeld-Merton apud Wolf, p. 57)

Se em 1948 esta era a visão do autor sobre a forma de distanciamento entre sujeito e os fatos mediatizados, entre o crime e o local do sofrimento de sua expiação, da mesma forma que aparecerá em Foulcaut a questão da punição do estado sobre o criminoso, mas que tal punição ocorra longe das vistas da sociedade média, o que se tem na sociedade contemporânea pode ser considerado algo similar, mas com um grau de acentuação mais elevado.

Nesta mesma medida, dirá Foucault que

Se a multidão se comprime em torno do cadafalso, não é simplesmente para assistir ao sofrimento do condenado ou excitar a raiva do carrasco: é também para ouvir aquele que não tem amais nada a perder maldizer os juízes, as leis, o poder, a religião. O suplício permite ao condenado essas saturnais de um instante, em que nada mais é proibido nem punível. Ao abrigo da morte que vai chegar, o criminoso pode dizer tudo, e os assistentes aclamá-lo. (Foucault, p. 59)

Novamente, quem agiu, quem execrou foi o condenado, e em uma contaminação, a plateia se sente agente, sente que xingou junto, quando na verdade apenas lhe seguiu as falas mas lhe faltou a força para se colocar me similar condição liberta para aferroar o sistema que lhe oprime.

A participação nas redes sociais digitais contemporâneas pode não diferir tanto deste histórico, aliás.

Curtir e compartilhar são métricas de sucesso em uma sociedade que vive flertando com a desconstrução do sujeito.

A exemplo, abaixo segue a campanha desenvolvida pela agência de publicidade Publicis para a Crisis Relief Singapore com fotos reais e usando o slogan "Liking isn't helping". Sua referência direta à cultura contemporânea de acompanhar os acontecimentos do mundo pelo

\footnotetext{
${ }^{6}$ Em livre tradução, "Curtir (no Facebook) não está ajudando".
} 
filtro de uma rede social usou a crítica sobre o que consideramos a ação, a ajuda em um mundo de conflitos.

\section{FIGURA 1}

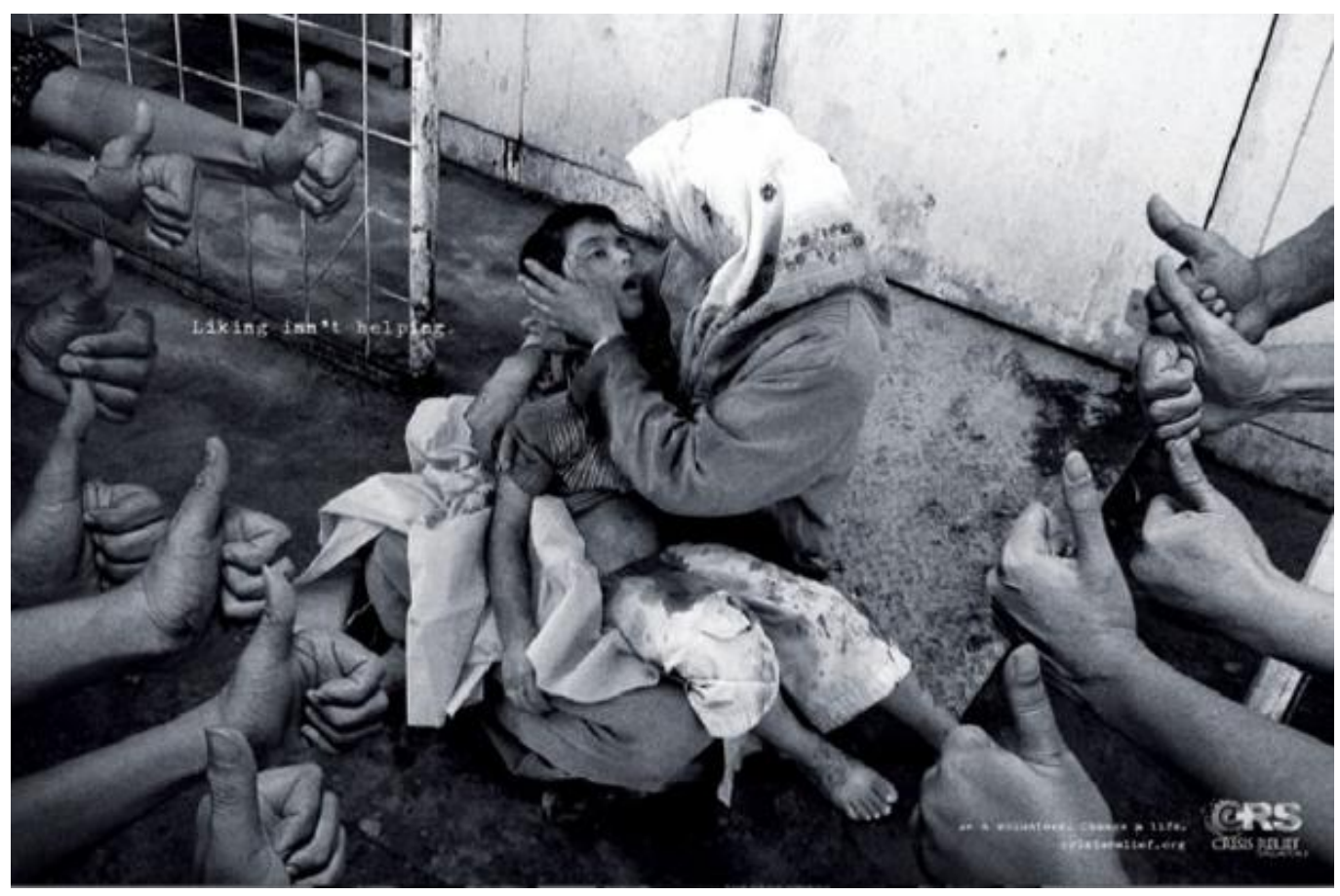

FIGURA 2

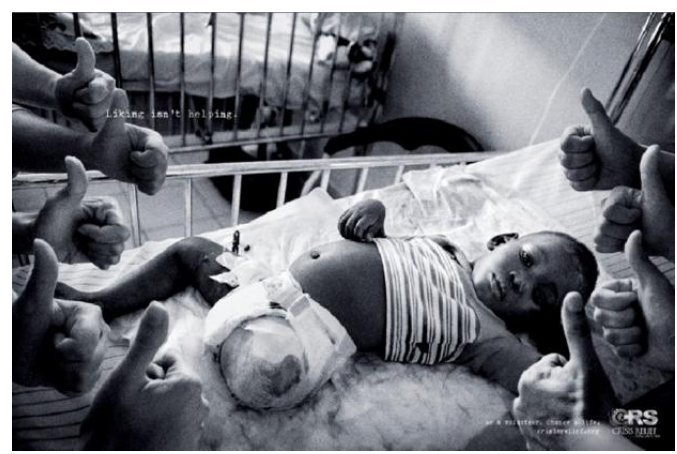

FIGURA 3

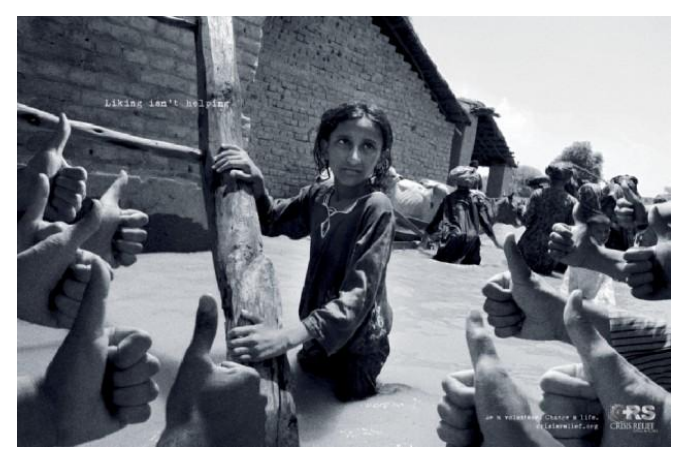

E em uma reação ao mesmo fenômeno, e ainda dentro da temática humanitária, em 2013 a Unicef se pronuncia através de sua Diretora de Comunicação na Suíça, Petra Hallebrant, com o seguinte texto noticiado pelo site Humanosphere?: "We like likes, and social media could be a good first step to get involved, but it cannot stop there [...] Likes don't save children's lives. We need money to buy vaccines for instance". Outra manifestação

\footnotetext{
${ }^{7}$ UNICEF asks people to stop 'liking' things on Facebook \& send Money. Disponível em <http://www.humanosphere.org/basics/2013/04/unicef-sweden-wants-your-money-not-your-likes/\#prettyPhoto>. Acesso em 2 de fevereiro de 2015.
} 
se deu com a comunicação oficial deste posicionamento através de sua campanha, em tom satírico ou, para alguns, bem humorado, indicando ironizando o excesso de curtidas que a página da própria Unicef tinha à época e o quanto isso poderia ser irrelevante frente aos problemas cotidianos que as pessoas atendidas pela instituição enfrentam.

Abaixo (Figura 4) é possível ver um exemplo de comunicação veiculada pela Unicef para potencializar sua campanha, além dos vídeos ${ }^{8}$ para o povo escandinavo.

\section{FIGURA 4}

\section{Like us on Facebook, and we will vaccinate zero children against polio.

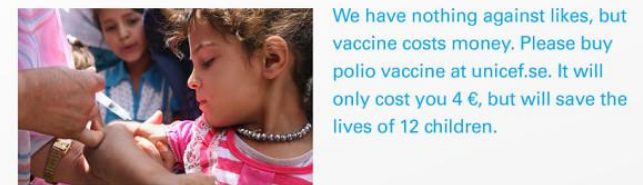

A velocidade das comunicações e a exigência da dromoaptidão podem estar, em reflexão e refletividade, pressionando e intensificando o estímulo para a produção de mais dados e informações, como curtidas e compartilhamentos, e para crer que age sobre o mundo, o indivíduo se convence que sua "curtida" se apresenta como manifestação, como ação. Claro que aqui não se pretende esvaziar o significado de tais atos de modo geral, mas apresentar a aceleração como mais um fator de pressão para gratificar os indivíduos com um efeito placebo sobre suas curtidas e compartilhamentos, como se a percepção de si próprio melhorasse ao apenas indicar que apoia uma causa, sem que de fato haja uma grande

\footnotetext{
${ }^{8}$ Likes don't save lives - UNICEF Sweden TV comercial. Disponível em: https://www.youtube.com/watch?v=2_M0SDk3ZaM>. Acessados em 2 de fevereiro de 2015.
} 
mobilização individual para reverter um cenário e alcançar soluções para os problemas sociais.

A comunicação interpessoal é hoje a base do conhecimento, da velocidade das crises sociais, dos comportamentos em cadeia e planetários, da decadência dos sistemas de representação social e de seus controles, cada vez mais frouxos e inúteis. É também, e cada vez mais, a base dos empreendimentos e da geração de valor econômico, social e cultural. (London, p. 116)

A bolsa de valores da cibercultura está a transpassar sua comunicação por diversas estruturas sociais, entregando o imperativo do homo velox que se aplicará para fazer parte dos grupos, da rede.

A apreensão do fluxo histórico da fenomenologia sociocultural empírica da velocidade técnica e tecnológica pode - a traços fincados em pontos estruturais sine qua non - ser consolidada com base em duas coordenadas básicas

1. a do sucesso cinético sobre o território, na forma do deslizamento [ou do "alisamento" espacial, para evocar Deleuze]; e

2. a da otimização progressiva de princípios funcionais e procedimentos operacionais de produção de resultados (sejam eles quais forem), vale dizer, de condensação dos mesmos no tempo, ou, numa palavra, de compressão temporal. Em ambos os casos, trata-se, fundamentalmente, de dois princípios: o de desempenho e o de eficácia, conjugados na menor escala de tempo possível, vigente a cada época. (Trivinho, p. 50-51)

No caso em tela, a aceleração das comunicações produzirá seus efeitos de saciedade instantânea, seguida de um novo vazio. Acelerados, os sujeitos se angustiam pela impossibilidade de obturar a hiância primordial por um tempo minimamente considerável e de forma minimamente satisfatória, mas da mesma forma, acabam por ter prazeres fugazes.

O ritual contemporâneo está extrair do sujeito seus dados e sua história com a promessa de um dia lhe entregar algo consolidado, algo de que fruir.

A cerimônia do sacrifício animal, do qual a tragédia grega, segundo Burket, deriva seu nome, expressava o temor e o medo sentidos por essa comunidade humana diante de suas próprias possibilidades assassinas. Representando ritualmente o assassinato de um animal, não de uma vítima humana, e cercando mesmo esse assassinato como uma cerimônia indicativa da inocência dos assassinos e de seu respeito pela vida, os sacrificadores, atores dessa "Comédia da Inocência" (Unschuldskomödie), se distanciam, e ao mesmo tempo reconhecem, as possibilidades de massacre humano que residem na natureza humana. Ao expressar sua ambivalência e remorso mesmo quando ao assassínio animal, humanizando o animal e demonstrando consideração por sua "vontade", os sacrificadores afastam de si a possibilidade pior: de matarem seres humanos, e os matarem sem piedade, tornando-se eles próprios bestiais. Suas ações rituais asseveram sua humanidade e simultaneamente o temor de deixarem de ser humanos. "O sacrifício humano... é uma possibilidade que, como horrível ameaça, repousa por detrás de todo sacrifício" (Nussbaum, p. 31)

Assim, que tipo de sacrifício se faz ao perseguir os cavaleiros do ciber crime que Assange (2012) apresenta e aniquilar os chamados criminosos sem, contudo, oferecer outros bodes em sinal de troca? 
O ciberativismo, criminalizado, é a transferência do peso da morte do homem comum ao animal afastado, a troca do reconhecimento das mutilações no corpo do seu igual trocadas, transferidas para um outro, que ao ser reduzido à categoria de criminoso pelo Estado ou mesmo pela opinião pública, receberá as chibatadas.

A agilidade castrará o tempo para refletir sobre quais sacrifícios estão sendo feitos.

Ao se cegar para as feridas em sua potência, o sacrifício é feito para simular a sua inexistência. A vigilância, sacrifício da liberdade, continua ocorrendo, mas a cena que está sendo apresentada para a plateia coparticipe é a da comodidade dos aplicativos e do capital social, do reconhecimento e reembolso da dromoaptidão.

Em resumo, a carne segue sangrando, mas a visão enxerga o bode.

O homem segue sendo subjugado mas o discurso prevalente, a violência sutilizada desta guerra, sobrepõe a imagem do flagelo humano pela comodidade vazia e esvaziadora. Em nome do bode que é apresentado para o sacrifício ritual, entregamos a nossa própria carne, o nosso próprio dado, parte do nosso eu.

A violência da técnica comparece atualmente (no social e na obra):

[...] 3. como acoplamento compulsório entre corpo e aparato mediático, entre subjetividade estética cibericonocrática hipertextual, entre imaginário individual e imaginário comunicacional automatizado, promiscuidade dessimbólica [...]

4. como pressão sociodromocrática pantópica, na modalidade de um gerenciamento infotécnico silencioso da dromoaptidão cibercultural, doravante o capital social requerido na esfera do trabalho e do tempo livre [...]

6. como produção social de segregação e de miséria sociossemiótica interativa, (produção) responsável por uma dromoproletarização progressiva e massificada; e

7. como deslegitimação, expurgo e/o denegação mediática da alteridade e do corpo (urdidura da morte espectral); enfim, a violência da técnica estruturalmente organizada como dromocracia cibercultural. (Trivinho, p. 39 - 40)

Se Trivinho (2007) coloca o imaginário individual próximo do que chamará de imaginário comunicacional automatizado, o faz em sentido diferente de Silva, para quem

O imaginário não é a cultura, nem a crença, menos ainda a ideologia. Por meio do imaginário o ser encontra reconhecimento no outro e reconhece-se a si mesmo. Em termos lacanianos distorcidos, através do imaginário o indivíduo torna-se o desejo do desejo do outro e deseja-se a si mesmo como objeto reconhecido de desejo. (Silva, 2012, p. 14)

O autor não conceberá qualquer forma de automatizar o imaginário, mas indicará em muitos momentos que a imagem serve à ideologia, enquanto o imaginário segue desconstruindo e metamorfoseando qualquer pilar. 
Ainda que este contraponto esteja dado, há de se considerar a violência pantópica, ou seja, que se apresenta em qualquer espaço, o que inclui o ciberespaço mas não exclui qualquer outro tipo de espaço, exercendo uma pressão silenciosa em direção à consagração e aplicação da dromoaptidão como capital social simbólico.

Frise-se que Trivinho (2007) destaca, no item 6, um ponto relevante de seu pensamento, o qual vai postular a velocidade como vertente concorrente para a dromoproletarização e segregação sociossemiótica de modo que não se encerre, mas siga aumentando a separação e a avaliação, julgamento e punição dos dromoinaptos.

Em resumo, ele dirá que tal violência e segregação é, em si, a dromocracia cibercultural.

Conquanto o sacrifício não seja de um, mas de muitos, de todos, a cibercultura acelerará as comunicações e camuflará a profundidade de suas violências sob os panos macios dos prazeres fugazes.

Anestesiados pelo fluxo contínuo de comunicação e pequenas gratificações, o indivíduo segue reproduzindo a estrutura que lhe castra ou ao menos que condiciona - novamente, não determina.

Com efeito, como a velocidade não é um acontecimento, a violência que lhe é própria não se põe como fato concreto aqui e acolá, a exemplo das modalidades empíricas, situacionais, visíveis e documentáveis de violência, sejam elas esporádicas ou recorrentes, cotidianas ou atípicas. A violência da velocidade comparece alçada à categoria de 'fato social total'. Ela se realiza em bloco, de uma vez por todas, e sempre. (Trivinho, p. 93)

Se a violência da velocidade se configuraria como fato social total, segundo o autor, só seria capaz de assim ser na mesma medida em que estiver permeada na sociedade como um todo. A velocidade, então, não deveria ser compreendida sequer como fator exógeno, mas como endógeno as estruturas sociais.

Sendo um pouco mais enfático, Trivinho dirá que

Tal é o telos da violência da velocidade; é para realizá-lo que ela, não por acaso, constrange, compele, arrasta os viventes - de modo soft, via sedução pela eficiência prática demonstrada quando se faz o que ela quer, vale frisar, quando se é dromoapto. A velocidade é o suave estupro do ser pela técnica alçada a fator apolítico aparentemente inofensivo. (Trivinho, p. 98, grifo nosso).

Tal estupro, tal violação não se dará apenas, diga-se de passagem, contra os dromoinaptos, mas também contra os dromoaptos. A aptidão à velocidade é uma violência contínua, e é justamente contra o dromoapto que a sutileza se apresenta em graus mais acentuados. 
O reprodutor das estruturas de vigilância e poder da velocidade cibercultural é, ainda que esteja em situação mais confortável, objeto e alvo desta violência.

E se por um lado o autor dirá que a violência sutil é a da velocidade, por outro, não será a única a se camuflar nas sutilezas simbólicas.

Sob o fluxo invisível das trocas e conversações sociais, constitui-se um imenso, distribuído e polivalente sistema de rastreamento e categorização de dados pessoais que, por sua vez, alimenta estratégias de publicidade, segurança, desenvolvimento de serviços e aplicativos, dentro e fora destas plataformas. Cruzando este processo, empresas e governos especializam-se em monitorar e coletar rastros, gerados pela navegação de usuários na Internet, construindo bancos de dados e técnicas de composição de perfis que orientam ações comerciais, políticas, securitárias, administrativas. Este monitoramento assume formas mais ou menos sutis, envolvendo desde mecanismos pouco visíveis de rastreamento de dados gerados pelas ações de usuários em plataformas, sites e aplicativos (através de rastreadores como cookies e beacons) até leis que instituem a filtragem e o monitoramento de navegações, como a lei francesa Hadopi, que criminaliza o compartilhamento de arquivos que violem a lei de direito autoral. (Bruno, p. $9-10$ )

A vigilância, sutilizada, camuflada, por vezes até desejada pelo indivíduo que pede proteção do estado será objeto de seus aparatos técnicos.

Assim, com o que Bruno destaca, é possível compreender que a vigilância não está centralizada, muito menos regulamentada.

Se o cerne desta obra é pensar no direito ao esquecimento, há de se ter em mente que, "technically, there is nothing that prevents individuals from offering their information online. The internet is a digital network, in which every participant can be a sender as well as a receiver.” (Mayer-Schönberger, p. 83)

Em casos como o da França, o motivo da lei Hadopi está em proteger interesses comerciais e, sob controvérsias, dar garantias do fomento cultural.

Nos Estados Unidos a vigilância se dá majoritariamente pelo pretexto da segurança, que se coloca, então, inclusive, acima da liberdade.

Neste passo, liberdade se torna algo questionável na medida em que também se torna negociável. Se a liberdade ou sua restrição já não estão sendo impostas ao corpo, mas sim à mente em uma sociedade contemporânea tocada e guiada pela cibernética, que cultura, então, pode se dizer livre? Em alinhamento com os ideais de Lévy, Tavares dirá que

Cultura Livre é a expressão de uma idéia que apresenta uma ética para novos padrões de sociedade. Revela um campo de disputa política na sociedade contemporânea e formas de liberdade correspondentes a ela. Grosso modo, a idéia de uma cultual livre alude a viabilidade de que os bens culturais possam livremente circular, ser acessados, manejados e transformados conforme diferentes necessidades e aspirações coletivas e individuais, objetivas e subjetivas. Este ideal decorre dos recursos das tecnologias contemporâneas da informação que permitem a 
intercomunicação global e a troca instantânea de informações, por meio da internet, além de constituírem o maior acúmulo de informações e conhecimentos da história humana, pelo trabalho coletivo, que é o ciberespaço. (Tavares, p. 251)

Retornemos, então, para Bruno, na coleta de dados que ocorre dentro desta que se pretendia ser uma cultura livre, através da sutileza de coleta de dados citada pela autora, o que não difere muito da sutileza da violência da dromoaptidão de Trivinho, vale apontar uma vez mais. Violência, violação que pouco se sente mas da qual se é objeto, seja da ativa, seja da passiva.

\subsection{VIGILÂNCIA E ESTRUTURAS DE DADOS}

Para abrir este capítulo, destaca-se que Abreu e Nicolau chegam a sugerir que a privacidade já não está mais em ponto de ser debatida, como se a dessem por encerrada. Para eles, "ainda que não sejam mais possível pensar em privacidade no âmbito do indivíduo, é possível pensar nas regras que estabeleçam limites para a coleta e o uso de todos esses dados, agora disponíveis." (Abreu \& Nicolau, p. 2, grifo nosso)

Esta indicação está atrelada à possibilidade atual de processamento em larga escala e agilidade de quantidades elevadas de dados e classificação maciça dos comportamentos e informações para traçar perfis de consumo, ou mesmo de inclinação política, por exemplo. Este é o campo do que está se chamando mercadologicamente de big data ${ }^{9}$, mas esta não é a única ótica para se pensar sobre a privacidade.

Recuperemos Arendt mais uma vez. Para os gregos antigos, o domínio privado era aquele do domicílio e da família. Era a esfera da necessidade, na qual os seres humanos se moviam por suas vontades e necessidades e onde investiam na sua própria reprodução e na da espécie. Ela era contrastada com a esfera pública, que era o domínio da liberdade, em que os seres humanos poderiam satisfazer todo seu potencia 1 como seres humanos. Assim, no pensa mento grego antigo, segundo Arendt, a esfera privada era entendida em seu sentido original de "privação", de "ser privado de": significava ser privado das coisas que compõem uma verdadeira vida humana, ser privado da realidade que acompanha o fato de ser visto e ouvido pelos outros, ser privado dos relacionamentos que advêm do compartilhamento de um mundo em comum, e ser privado da possibilidade de conquistar algo mais duradouro que a vida em si (Arendt, 1958: 58). Então, no pensamento grego antigo o domínio privado era realmente secundário em relação ao domínio público: era esse último que realmente importava, e o domínio privado era relevante apenas por dar as condições necessárias para que os indivíduos sobrevivessem e assim participassem do domínio público. (Thompson, p. 23)

\footnotetext{
${ }^{9} \mathrm{O}$ termo big data está ligado a técnicas de coleta e cruzamento de dados em busca de informações que possam traçar os perfis de conduta das populações observadas. Seu âmbito mais comum é a comunicação e dados digitais devido à alta disponibilidade de dados diversos sobre cada usuário da internet.
} 
É interessante pensar que em na antiguidade grega, a privacidade não necessariamente seria um campo positivo, mas sim de isolamento e exclusão. De certa forma, com as mídias de comunicação em rede conectadas à internet e a constante evasão de informação proporcionada pelos próprios indivíduos, ainda que estimulados pela cibercultura, estaria levando a sociedade a uma reedição grega do termo.

Enquanto o sentido de privado estiver atrelado à privação, à perda, o público será a reconquista. Mas quando o público se torna a totalidade, perde-se o campo de reflexão individual para a espetacularização pública. Thompson reiterará que "acima de tudo, a esfera privada proporciona aos indivíduos um espaço para se recolher do brilho da vida pública e de ser constantemente visto e ouvido pelos outros." (Thompson, p. 24)

Tais palavras indicam que há, sim, em todos uma parcela da vida pública, coletiva, comum e compartilhada, mas há ainda o momento de recolhimento, de afastamento que é necessário para cada indivíduo.

Assim, dividido entre o público e o privado, entre o eu e o grupo, está o sujeito.

Como é conceituada a articulação, a organização e a síntese dos aspectos pessoais e sociais da identidade? Para responder a esta questão, deve-se partir da ideia segundo a qual todo indivíduo seria caracterizado, de um lado, por traços de ordem social que assinalam sua pertença a grupos ou categorias; e, do outro, por traços de ordem pessoal, atributos mais específicos do indivíduo, mais idiossincráticos. Os primeiros traços definem a identidade social de uma pessoa. (Deschamps , p. 23)

Deschamps e Moliner apresentam, então, dois polos da compreensão do indivíduo em sua obra intitulada "A identidade em psicologia social", de modo que nem o sujeito é completamente fruto do coletivo, do social, nem é ele apenas partícula dura que resiste ao grupo.

A questão que aflora entre o eu e o grupo, entre a influência do social e as estruturas de vigilância, bem como entre a publicação da privacidade, é que as formas de coletas de dados estão se sofisticando a cada dia mais.

No caso do big data, quando cada clique ou mesmo não-clique passa a se tornar dado quantificável, coletável e analisável, a utopia dos anos 90 sobre a internet libertária passa a dividir espaço com os sistemas de monitoramento e controle, que utilizam técnicas estatísticas e cálculos avançados para auxiliar a previsão e condicionamento do modo de consumo, através da publicidade, nos dias de hoje, mas que da mesma forma podem agir como ferramentas ideológicas, se é que o modo atual de conduta já não tenha se convertido em uma ideologia que tem por base as estruturas do capital. 
A more exacting digital memory may aid businesses in designing and producing more precisely the goods people prefer, and in marketing them to better-defined target groups, thus sparing them, consumers, and the environment from millions of tons of unwanted marketing and advertisement material (although consumers are uncomfortable being targeted that way). (Mayer-Schönberger, p. 93, grifo nosso)

É interessante perceber como o autor indica que haja uma preferência que aflora do grupo de pessoas através dos dados da memória digital. Assim, a camada infotécnica está a escrutinizar as condutas sem que necessariamente o indivíduo tenha consciência de que cada ato seu tem se tornado uma escolha clara e deliberada para as estruturas de big data.

Unfortunately, the potential consequences of a default of remembering on our ability to maintain control (and thus have power) over information are rarely transparent. They take place without us noticing much - at first. We may suffer a reduction of control over our information before we realize it. By the same token, others gain in information power from our loss, influencing the circumstances of our future interactions with the world and how we function as a society. (Mayer-Schönberger, p. 101)

Um exemplo controverso de uso das redes como estruturas de vigilância, dentro desta ecologia da memória sobre os atos online (por enquanto), é o caso da família que foi abordada em sua residência em Long Island, no estado de Nova Iorque, por agentes policiais após algumas pesquisas no site de buscas Google. Coincidentemente, a esposa havia feito buscas relacionadas ao termo "panela de pressão" enquanto o marido havia usado o buscador para encontrar páginas relacionadas a "mochilas".

O nexo que levou os policiais à casa da família Catalano é que as buscas ocorreram no mesmo período de um atentado em solo americano através um artefato construído com uma panela de pressão, abandonada dentro de uma mochila, que explodiu em meio a uma maratona na cidade de Boston $^{10}$.

Estamos acostumados a pensar na rede como uma série de relações distintas: nós gerimos a nossa relação com o Yahoo separadamente da nossa relação com nosso blog preferido. Entretanto, nos bastidores, a rede está se tornando cada vez mais integrada. As empresas estão percebendo que compartilhar dados é lucrativo. (Pariser, p. 45-46)

Pariser destaca que não há desconexão. Os dados não estão apartados, ou se estão, isso é uma questão de tempo e interesses, ainda mais considerando o hiato legal que se apresenta em muitos países. Mas o que faltou ao autor foi a inclusão do que hoje convencionou-se chamar de "mundo real" nesta amálgama midiática. Não é apenas entre o Yahoo e os blogs que se faz distinção, mas da mesma forma, acredita-se corriqueiramente que o digital e o "real" estejam apartados.

\footnotetext{
${ }^{10}$ Família recebe visita da polícia após busca por panela de pressão na web . Disponível em: <http://g1.globo.com/mundo/noticia/2013/08/familia-recebe-visita-da-policia-apos-busca-por-panela-de-pressaona-internet.html>. Acesso em 2 de fevereiro de 2015.
} 
Nem o estão em termos tecnológicos, muito menos sociais.

Os dados compartilhados ocorrem entre diversas empresas sem que o indivíduo que é a origem das informações precise necessariamente estar ciente de tamanha convergência de dados a seu respeito. Sua vida cotidiana está escrutinizada e espetacularizada para suavizar a violência da extirpação de dados pessoais, mas as estruturas do capital seguem impelindo companhias a compartilharem seus dados.

Plenty of private companies are already collecting data - mostly for marketing
purposes - that governments, both authoritarian and democratic ones, would find
extremely useful. Thus, while the KGB may no longer exist in 2020, its functions
may still be performed by a smattering of private companies specializing in one
particular aspect of information work. (Morozov, p. 166)

$\mathrm{Na}$ medida em que os resultados financeiros crescem e os entraves jurídicos se mantém estáveis ou praticamente nulos, o compartilhamento e cruzamento de dados segue ocorrendo a despeito do que pode ser considerado ético.

Sua localização pode ser estimada de acordo com os locais de reconexão com a rede. Aliás, a rede não é a internet, mas sim a sociedade, que agora tem em suas entranhas a cibercultura e a internet como um dos maiores aparatos técnicos deste processo parasitário revestido de simbiose para alguns, de comensalismo para outros.

Elevados ao extremo, este anulamento da alteridade e da história poderia, então mantendo o paralelo metafórico da biologia, se constituir em uma antibiose, dificultando o crescimento e desenvolvimento de formas de vida específicas. Neste caso, formas de pensamento ou de dinâmicas sociais específicas, que passam a ocorre dentro de um filtro de vigilância e lutas sutilizadas.

O exemplo da família Catalano é um caso que pode indicar um dos caminhos para os quais a internet, a sociedade e a cibercultura estão rumando.

Com o chamado big data, informações que antes eram desconhecidas ou desconsideradas agora passam a serem correlacionadas em busca de padrões lógicos de dados.

A privacidade, em solo estadunidense, foi conduzida a valor secundário, suplantada pela segurança nacional e pela vigilância autorizada do Estado sobre todos os seus cidadãos e dados trafegados em solo nacional.

O big data é produto da evolução contínua da computação e da comunicação, uma consequência da comunicação pervasiva e da ubiquidade da informação, da midiatização: pessoas, máquinas e ambientes comunicam-se através do mesmo código, compartilhando informações diuturnamente. (Abreu \& Nicolau, p. 1) 
Desta forma, não há de se pensar que este cruzamento de dados esteja apenas ocorrendo por conta das estratégias mercadológicas, se não também por conta das características desencadeadas pela aceleração comunicacional e também pelos saltos tecnológicos que permitiram tanto o armazenamento de dados em grande escala quanto o seu processamento em tempo reduzido, e de modo mais vertical no âmbito da vigilância a partir da crise de segurança originada pelos atentados de 11 de setembro de 2001 contra os Estados Unidos.

Instead of protecting citizens from overbearing surveillance and memory, policy makers are compelling private sector data collectors to perfect the digital memory of all of us, and keep it easily accessible for public agencies from the intelligence community to law enforcement. (Mayer-Schönberger, p.9)

A disponibilidade em tempo real de rede de bancos de dados coloca no tempo presente a disponibilidade também da vigilância, mesmo que para isso acabe servindo-se de dispositivos que não tenham sido desenvolvidos com este propósito inicialmente.

[...] é importante destacar que o fato de a vigilância não estar inicialmente prevista em certas tecnologias não $\mathrm{a}[\mathrm{s}]$ torna[m] neutra[s] ou sem efeito. [...] Mas o fato de a vigilância estar presente como uma possibilidade da próprias arquitetura desses dispositivos não implica, contudo, que ela seja necessária. Ela pode muito bem não se atualizar; mas, quando se atualiza, opera no interior do próprio dispositivo modulando-o e não descaracterizando-o. (Bruno, p. 32 - 33)

Desta forma, percebe-se que os aparatos tecnológicos podem ser usados para a vigilância independentemente das razões e intenções para as quais foram criados.

The private sector will surely continue churning out innovations that can benefit secret police everywhere. Without finding ways to block the transfer of such technologies to authoritarian states or, even more important, the kind of limits that should be imposed on such technologies everywhere, the West is indirectly abetting the work of the secret police in China and Iran. (Morozov, p. 160 - 161)

Um relógio que mede a temperatura corporal pode indicar oscilações bruscas e servir de alerta de atentados da mesma maneira que o celular pessoal pode ser usado em rede para transmitir em tempo real as imagens de qualquer espaço. Por este motivo que Assange indicará que "o celular é um dispositivo de monitoramento que também faz ligações". (Assange, p. 68)

Bruno ajuda a tirar o viés da produção tecnológica, em si, mas indicando que os dispositivos podem servir a ideologias atreladas à vigilância sem que isso exija uma mudança abrupta na estrutura destes, mas com a remodulação de seu processamento e transmissão de dados.

A vigilância, aliás, se dará através do aparato sociotécnico, o que significa que o olho do escrutínio é tanto tecnológico quanto humano. Não se pode, então, pensar no contraste entre 
sociedade e tecnologia na medida em que hoje esta serve à vigilância de ideologias, mesmo que seja a ideologia do capital, que se torna mais evidente para leigos no caso da publicidade, mas que também permeia as estruturas políticas.

Os Aparelhos Ideológicos do Estado, presentes no discurso de Althusser, terão a função de "incluir uma visão de mundo nas mentes do dominados." (Silva, 2012, p. 19)

Agora, ainda que esta seja uma visão das ideologias, entrando no campo do imaginário, há outro caminho a seguir. Enquanto a ideologia conforma, o imaginário seria o berço da transformação. "Considerando-se essa perspectiva data da, embora não totalmente impertinente, será melhor falar, hoje, em tecnologias do imaginário" (Silva, 2012, p. 19) conclui o autor.

Mas tal inversão não necessariamente se coloca como contraste categórico, mas suas sombras aumentam a complexidade do debate. Imaginário e ideologia são opostos conectados.

Quando se pensa no determinismo da ideologia e na panspermia do imaginário, se mostram opostos. Mas ao pensar em quais são os fatores distintivos das culturas, ou seja, aquilo que separa os conjuntos e a alteridade, este fator seria justamente o imaginário. "Aquilo que separa uma cultura da outra é o imaginário (a representação) que cada cultura engendra para si mesma." (Silva, 2012, p. 16)

Mas se esta separação acontece no nível do imaginário entre culturas, quando a cibercultura se instala transnacionalmente, é dúbio em que medida o imaginário está se tornando fator distintivo ou homogêneo. Enquanto as possibilidades da internet estiverem separadas de sua prática de filtros autoengendrados e sujeitos autorreferentes, tal separação seguirá em xeque. "Cada vez mais, o monitor do nosso computador é uma espécie de espelho que reflete nossos próprios interesses, baseando-se na análise de nossos cliques feita por observadores algorítmicos." (Pariser, p. 9)

A questão é que mesmo dentro das ideologias não há grande espaço de participação e florescimento de identidades livres.

Não há nada mais perigoso do que ver na presença das novas tecnologias cada vez mais performáticas a condição para a aproximação entre os homens. É na realidade o contrário. Quanto mais estão próximos uns dos outros, mais as diferenças são visíveis, tanto mais é necessário garantir certas distâncias para suportar as dessemelhanças e conseguir coabitar. (Wolton, p. 11)

A descoberta aprofundada do outro, saber seus gostos e suas opiniões sobre tantas coisas pode levar à aproximação de alguns mas o distanciamento de tantos outros. 
Ao mesmo tempo que se separam, sentem-se próximos justamente pelo esfacelamento dos contornos mais tangíveis do privado e do público, fator que já fora anteriormente mencionado.

Se a privacidade do outro se aproxima da sua, mesmo que no campo público, o espaço de intimidade pode parecer reestabelecido, mesmo que as estruturas de vigilância estejam atuando para obter e, em m segundo momento, agir sobre estes dados e cada conduta.

Porém, quando esta visão se alarga no tempo, mesmo as opiniões altamente convergentes sobre um tema podem não ser suficientes para manter um grupo unido quando houver divergências claras sobre outro assunto de grande monta.

Um exemplo mais recente pode ser considerado a divisão dos grupos governistas e oposicionistas na internet. Enquanto antes o assunto poderia surgir em uma conversa ou outra, mas também poderia ser evitado em favor de um período de calmaria e não agressão entre os membros do grupo, hoje as opiniões manifestadas nas redes sociais surgem a todo momento, mudando a quantidade de comentários disponíveis e arquivados sobre um tema e também a qualidade das discussões sobre cada assunto. Assim, mesmo que comentários extremos encontrem eco em parte do grupo reunido nas redes sociais, sempre haverá aquele que terá acesso a esta visão extremada e considerará iniciar um confronto sobre as manifestações de visão de mundo. Em outras palavras, da mesma forma que a tecnologia contemporânea colocou muitos em contato com muitos, suas opiniões também estariam expostas para decidir se vale a pena estar em contato ou não com estas pessoas.

E todas estas vozes estão sendo catalogadas, classificadas e reagrupadas, para que na companhia de iguais possam se sentir satisfeitas e, com isso, manter sua ação compulsiva e compulsória de gerar e entregar ainda mais dados para a rede.

Em tempos anteriores, um sujeito de direita política poderia fazer parte de um grupo de esquerda em busca de algo que lhe fosse caro, como pessoas específicas ou relações sociais, sendo que suas afiliações dificilmente viriam à tona.

Contudo, com a profusão de informação e de comentários nas redes sociais, o sujeito está exposto e precisa se expor ainda mais.

Social networking sites do not usually hide lists of group members from nonmembers, so as not to erect too many communication barriers. It is thus possible to produce a nearly unique identifier, a "group fingerprint" - think of this as a list of all Facebook groups that a given user belongs to - for each of us. And the most obvious place to look for a matching fingerprint would be in our web browsers' history, for this is where a record of all the groups - and, of course, of all other 
websites we visit - is kept. All it takes to steal our browser history is to have us click on a malicious link, like the one mysteriously added to RSF's email petition, and everything we have been browsing in the last few days will no longer be private knowledge. (Morozov, p. 161)

Este é o imperativo da rede e da agilidade das comunicações. Ao comentar, então, uma notícia sobre o Bolsa Família concordando, sem muita profundidade de pesquisa ou sem fatos comprovados, que seus beneficiários seriam todos vagabundos que não querem emprego, o sujeito estaria ainda mais exposto a ser confrontado e expulso ou excluído gradativamente de grupos que vejam nisso um pensamento preconceituoso e estigmatizante.

Mas ainda que esta aceleração das comunicações sirva para alimentar com dados a rede, e em seu efeito colateral possa estar a sensação de presença, mas através do distanciamento mediado, a cibercultura seguirá demandando mais velocidade.

Os aparatos de vigilância, cada vez mais aceitos e convidados a entrar em diversos espaços, de banheiros a salas de aula, de motéis a escritórios, converterão cada estrutura infotécnica que puderem. Exemplo disso é a televisão, que frente à dromocracia e inovações tecnológicas está ganhando sua camada de dados para que possa se converter em aparato interativo, por um lado, e de coleta e classificação de dados pelo outro.

Isso é o mesmo que indicar que as estruturas de controle não estão dadas, por si, mas que a infraestrutura sociotécnica pode ser - facilmente - convertida em estrutura de vigilância, e de seu derivado, o controle, incorporando, assim como a ideologia do capital, não apenas os traços públicos ou a força de trabalho, o ente político ou mesmo como consumidor, mas estará presente até mesmo no lazer e diversão, como se pode notar nas redes sociais majoritárias, que são um grande banco de dados que expõe parte destes dados para a coletividade de modo explícito, parte para anunciantes e governos de modo implícito, e ainda atua de modo sutil ou, em alguns casos, de alta dificuldade para percebê-lo, na mudança dos padrões de comportamento ou manifestação.

Antes de retomar este ponto, é importante entender que a vigilância está posta para empresas, marginais e até mesmo para o cidadão "de bem", já que "[...] vigias e vigiados, hoje esses dois termos gozam de uma relativa indiscernibilidade, assim como todos podem ser potencialmente vítimas ou suspeitos.” (Bruno, p. 31) A privacidade passa a ter contornos difusos em uma sociedade na qual a vigilância se torna possível de modo pervasivo.

Por exemplo, Beate Rössler (2005) define privacidade como a habilidade de controlar o acesso a algo, do qual a informação é uma das formas, havendo outras. A autora distingue três dimensões da privacidade: privacidade informacional, que é o controle das informações sobre nós mesmos e o direito de protegê-las do acesso indesejável de outras pessoas; privacidade decisional, que é o controle de nossas 
decisões e ações e o direito de protegê-las da interferência indesejada por parte de outras pessoas; e a privacidade espacial, que é o controle de nossos próprios espaços e o direito de protegê-los contra a invasão indesejada de outras pessoas. (Thompson, p. 26)

Esta classificação ajuda a compreender de modo mais aprofundado alguns níveis e campos da privacidade, e como tal, indicam os níveis de possível pervasão das estruturas infotécnicas para coleta e classificação de dados. "A transferência da informação não pode ocorrer sem certo dispêndio de energia, de modo que não existe nítida delimitação entre acoplamento energético e acoplamento informacional.” (Wiener, p. 39) Trazendo para o contexto desta obra, então, a observação e vigilância não poderão capturar o sujeito em sua forma exata. O plano simbólico, assim como o físico, não serão capazes de apreender em sua totalidade qualquer que seja o sujeito.

Enquanto a física compreende que a observação de qualquer partícula transforma o seu comportamento, justamente pela transferência de informação no ato de observar, e como tal, de coletar a energia, a vigilância incide sobre um corpo que só existe sob vigilância.

Uma mente vigiada é apenas a mente vigiada, não o que seria ela sem este acompanhamento. É de se apresentar, então, o ciclo retroalimentado de informação e vigilância que olha não homens e mulheres livres, mas homens e mulheres vigiados como o são.

A sociedade infotécnica está abraçada com seu produto, com seu substrato, mas também com sua origem. A técnica, permeando todos os estratos sociais (ainda que com intensidades performáticas e visíveis diferenciadas) está formando aquele que lhe forma, em uma metavisão e metaprodução.

A questão da privacidade informacional está diretamente atrelada ao objeto deste estudo, porém o mesmo pode se falar tanto da privacidade espacial, ainda mais quando os pontos de acesso destes dados estão distribuídos entre várias tecnologias que hoje são comuns em muitas casas, como aparelho celular, computadores, tabelias e até mesmo televisores "inteligentes", e a privacidade decisional, que como colocado acima não se liga diretamente em ter um bloqueio ou delegação das decisões, mas na interferência que pode ocorrer dentro do âmbito privado. Assim, privacidade informacional, espacial e decisional estão todas implicadas nas estruturas de dados.

A fazer um contraponto sobre em que medida a privacidade informacional e decisional se cruzam de modo mais direto a barreira da tomada de decisão, ao menos na manifestação de 
humor, se não indo mais longe na própria percepção dos sentimentos compartilhados socialmente.

No artigo intitulado Experimental evidence of massive-scale emotional contagion through social networks, os membros do Centro de Ciências da Informação do Facebook indicam, através de um experimento com mais de 689 mil usuários de sua rede social homônima e que durou uma semana (de 11 a 18 de janeiro de 2012), que ao usar uma ferramenta de avaliação e classificação de palavras foi possível influenciar e contaminar a manifestação de humor dos participantes sobremaneira.

O experimento omitia palavras positivas da linha de notícias da rede social de um grupo e constatava que, ao fazê-lo, os participantes (involuntários, diga-se de passagem) do estudo eram contaminados por sentimentos negativos em suas publicações e comentários. O mesmo ocorria na omissão de termos negativos, levando os participantes a utilizarem mais palavras positivas em comentários e publicações subsequentes.

Passa-se, então, da questão da tecnologia e dos dados como fatores com potencial de interferir na privacidade decisional para a constatação direta e massiva de que esta interferência pode não ser tão marginal, ainda que silenciosa para muitos.

O que o estudo acima, publicado na revista PNAS (Proceedings of the National Academy of Sciences of the United States of America), pode indicar não é um poder determinante, mas condicionante. Em outras palavras, a rede de dados e algoritmos não pode garantir e obrigar uma pessoa a se sentir melhor ou pior em dado momento, mas pode oferecer condições mais favoráveis a comportamentos específicos.

Lévy argumentará que

As verdadeiras relações, portanto, não são criadas entre "a" tecnologia (que seria da
ordem da causa) e "a" cultura (que sofreria os efeitos), mas sim entre um grande
número de atores humanos que inventam, produzem, utilizam e interpretam de
diferentes formas as técnicas. (Lévy, 1999. p. 23)

A técnica e a tecnologia não serão determinantes, pelos termos do autor, mas estarão presentes na dinâmica relacional dos processos de significação.

Assim, por mais que a bolha de informações possa trazer as condições, enquanto houver a possibilidade de ignorá-la ou mesmo de desconfiar dela, o determinismo seguirá perdendo esta disputa. Mas em um cenário hipotético no qual a maior parte das informações consumidas pelos indivíduos de um grupo tiver como origem o mesmo meio de comunicação, ainda que seja uma rede social, há chances de viés, seja ele intencional ou não. E por mais que 
se acredite que este cenário possa ser altamente hipotético, segundo estudo do Pew Research Center $^{11}$, entre os estadunidenses que possuem um perfil no Facebook, $63 \%$ já usam a rede para acompanhar notícias.

Já a revista Exame ${ }^{12}$ destaca um outro fator da pesquisa, que diz, de modo geral, que $61 \%$ dos jovens recorrem ao Facebook para ler notícias sobre política e governo. Já a Quartz, agência estadunidense, publicou um ranking no qual "o Brasil aparece em primeiro lugar, com $67 \%$ de sua população buscando informação, prioritariamente, na rede social. Também ocupamos a liderança na utilização do Facebook para fins diversos, com 80\%"13.

Ou seja, a concentração da mídia de massas clássica, que tinha como seu maior expoente a televisão, agora perde espaço para uma rede social que mal se define como uma mídia jornalística, mas que se acopla à produção tanto jornalística quanto noticiosa para prover informação e reter usuários. Agora a mídia monolítica não existe, mas tão pouco se pode dizer que de fato tenha se dizimado.

Se a confiança nas agências de notícias está caindo, a confiança no novo mundo da
curadoria amadora e algorítmica está aumentando. Se as páginas dos jornais e
revistas estão sendo arrancadas por um lado, estão sendo recompiladas por outro -
numa ordem diferente a cada vez. É por isso que o Facebook está se transformando
numa fonte cada vez mais vital de notícias: nossos amigos e família têm mais
possibilidade de saber o que é importante e relevante para nós do que qualquer
editor de jornal em Manhattan. (Pariser, p. 62 )

Ainda que tenha se debatido o efeito da bolha de conteúdos nas manifestações ou campanhas eleitorais, este efeito ainda seguiu, até onde se sabe, sem um viés específico dos administra das redes ou dos códigos.

Não se tem notícias de uma mudança nos algoritmos para enviesar a visão de um grupo sobre um item específico, como política, economia, games, publicidade.

Mas um caso similar chama a atenção. Com a aprovação do casamento entre casais homossexuais pela corte dos Estados Unidos foi oficialmente apoiado, em seguida, pelo Facebook, que disponibilizou um aplicativo simples que ajudava as pessoas a inserirem uma camada de cores do arco-íris sobre suas fotos do perfil na rede social.

\footnotetext{
${ }^{11}$ Já 63\% leem notícias no Facebook e Twitter. Disponível em: <http://www.cmjornal.xl.pt/tecnologia/detalhe/ler_as_noticias_do_dia_no_facebook_e_no_twitter_esta_a_tornar _se_cada_vez_mais_comum.html>. Acesso em 18 de julho de 2015.

${ }_{12}$ Para nova geração, lugar de política é no Facebook. Disponível em

<http://exame.abril.com.br/tecnologia/noticias/para-nova-geracao-lugar-de-politica-e-no-facebook>. Acesso em 18 de julho de 2015.

${ }^{13}$ Cerca de $70 \%$ dos brasileiros ativos no Facebook se informam pela rede social. Disponível em <http://observatoriodaimprensa.com.br/e-noticias/cerca-de-70-dos-brasileiros-se-informam-pelo-facebook/>. Acesso em 1 de maio de 2015.
} 
Para quem participou desta "mobilização" online, muitas vezes o sentimento foi de apoio massivo da rede para esta causa. Porém os números mostram o contrário e, com isso, ratificam a bolha de conteúdo que faz quem está em seu centro não perceber como seu olhar está sendo conduzido pelas estruturas de dados.

Como noticiou o jornal El País ${ }^{14}$, menos de $2 \%$ dos usuários do Facebook trocaram sua foto. Um número irrisório comparado à visibilidade que a ferramenta deu às trocas de fotografias de perfil. Um sinal claro do que se conhece como viés da disponibilidade. Para Dobelli, este viés é descrito como o modo pelo qual "fazemos uma ideia do mundo com base na facilidade com a qual exemplos nos ocorrem". (Dobelli, p. 45)

O mesmo ocorre com a sensação de insegurança de quem assiste muitos programas de perseguição policial. Assim, quanto mais se vê algo, maior é a tendência a acreditar que este volume de informação recorrente é um padrão dentro da sociedade como um todo, não percebendo o próprio enclausuramento em uma bolha de dados.

Para seguir, tem-se o resgate que Thompson faz da visão de Helen Nissenbaum, que apresenta justamente um fator complexificador, aqui relembrando o próprio paradigma da complexidade, que retira o viés determinista das relações de privacidade e, como tal, de publicidade, memória, esquecimento em cada contexto.

[...] a privacidade tem sempre de ser analisada na relação com as diferentes esferas ou contextos em que os indivíduos vivem. Em cada uma delas há normas específicas para regular o que é apropriado e aceitável na maneira como a informação é revelada e compartilhada. (Thompson, p. 27)

Isso está em consonância com dois pontos importantes. O primeiro é a polivalência das estruturas sociais e tecnológicas que participam do processo comunicacional e que podem, assim, assumir diferentes níveis de invasão e evasão da privacidade, bem como das consolidações de memórias infotécnicas, mas também, no segundo ponto, há certa percepção diferenciada de cada indivíduo sobre tais estruturas infotécnicas de acordo com o seu momento, contexto e interesse, sendo que nem sempre este indivíduo se sentirá imediatamente oprimido pelos aparatos tecnológicos de visibilidade, dados e memória.

Redes como o Facebook estão ternando o modo como capturam dados algo ainda mais pervasivo, segundo Nik Cubriloivc.

Facebook has had privacy issues for a long time, and while the company has been working to improve its image, today's episode will likely set it back once again.

\footnotetext{
${ }^{14}$ Se você adotou a foto com as cores do arco-íris no Facebook, isso te interessa. Disponível em <http://brasil.elpais.com/brasil/2015/06/30/tecnologia/1435666552_856487.html>.

Acesso em 1 de julho de 2015
} 
Thanks to a modified cookie, Facebook allegedly knows what you're doing online even when you're not logged in.

At least that's what self-proclaimed hacker Nik Cubrilovic claims. After running a series of tests analyzing the HTTP headers on requests sent by browsers to facebook.com, he discovered that Facebook alters its tracking cookies the moment you $\log$ out, instead of deleting them. Since your uniquely identifying account information is still present in these cookies, Facebook can continue to track you, Cubrilovic argues. ${ }^{15}$

Ou seja, não apenas as tecnologias estão na vertente de consumo dos dados e estímulo de sua entrega, mas também, por outro lado, o indivíduo se insere na dinâmica de negociação de valores e imagens, apropriando-se ao menos parcialmente da linguagem da vigilância espetacular para dar visibilidade a pontos de seu interesse.

Carece saber se, dissociados da vida cotidiana e recorrente deste indivíduo, estariam estas mensagens e artefatos de memória fadados a serem soterrados por outra camada de dados algorítmicos que "corrigirão" o viés humano na entrega de dados ao longo do tempo, ainda que "pensar a memória não [seja], simplesmente, entrar no passado e encontrar fatos, pessoas, lugares nos quais vivemos e conhecemos em algum momento de nossa vida. É muito mais complexo." (Bernardo, p. 100)

O sujeito vigiado, então, é também o sujeito que perde parte de sua autonomia quando o controle é exercido por qualquer ente com acesso e gestão sobre os códigos e ferramentas infotécnicas.

\begin{abstract}
No campo das práticas de vigilância, elas não apenas se diversificam, como se tornam extremamente presentes no cotidiano da vida urbana e social. A expansão da videovigilância, notável nos grandes centros urbanos após os atentados de 11 de setembro de 2001 nos Estados Unidos, reorganiza as relações entre segurança e vigilância. Elas não mais focalizam populações e espaços classificados como perigosos ou suspeitos, mas se dirigem a toda sorte de espaço público, semipúblico ou privado. Paralelamente, o fluxo de informações que circula no ciberespaço se torna um foco privilegiado de monitoramente por diversos fatores e segundo diferentes propósitos: comercial, publicitário, administrativo, securitário, afetivo, entre outros. (Bruno, p. 8)
\end{abstract}

Resgata-se, aqui, o caso a pouco citado da família que teve suas buscas na internet relacionadas ao atentado de Boston por uma correlação indevida entre os itens utilizados, o cenário e as palavras usas nas incursões pela internet.

A vigilância pantópica, que está em todos os lugares, seguirá sutil até que faça uso das informações adquiridas para, de modo direto e abrupto, reconduzir um comportamento

\footnotetext{
${ }^{15}$ Facebook tracks you online even after you log out. Disponível em <http://www.zdnet.com/article/facebooktracks-you-online-even-after-you-log-out/>. Acesso em 3 de junho de 2015.
} 
considerado indevido. Se este ruptura não ocorre, dificilmente as ações sutis das redes algorítmicas serão consideravelmente sentidas.

[...] o furor pelo controle cívico tem como sua outra face a negligência ou a harmonização que anula a força especial de cada uma das preocupações isoladas que preenchem a cidade e lhe conferem sua substância. Desse modo, a declaração dos triunfos humanos pela razão acaba por mostrar-se também um documento condensado das limitações, transgressões e conflitos da razão. Sugere que, quanto mais rico for o nosso sistema de valores, mais difícil será efetivar uma harmonia em seu interior. Quanto mais abertos somos à presença do valor, da divindade, no mundo, tanto mais certamente o conflito nos cercará. O preço da harmonização parece ser o empobrecimento, o preço da riqueza, a desarmonia. (Nussbaum, p. 65)

Então, em uma continuação desta avaliação, se a vigilância, bem como o conhecimento e tratamento dos dados poderiam conduzir a uma massificação das condutas e dos cenários disponíveis, seria esta a via de empobrecimento, de esvaziamento do humano médio. O que se questiona é em que grau isso poderá, de fato, se dar, e em que medida receberá considerável resistência.

O pós-panóptico é apenas um modelo de vigilância - através das tecnologias de informação e comunicação o poder é mutável. Neste modelo, não existe mais um poder centralizador que dissemine controle, vigilância e dominação (como a sociedade disciplinar de Foucault), pois os indivíduos podem fazer uso da tecnologia para criar novas relações de poder. (Corso, p. 5)

Mas justamente neste item que pode ainda restar mais uma questão primordial. Se a rede não tem centro e seus nós são rizomáticos, a queda dos algoritmos deixa de ter um alvo físico, se é que um dia teve. Por este motivo, o foco excessivo em algumas poucas corporações majoritárias é uma névoa que encobre o debate realmente necessário. Se as relações de poder passam a ser operadas em conjunto com as estruturas de filtro e algoritmos de construção de realidades auto-engendradas, qual é a disputa de poder a ser travada? Contra quem? Contra qual vontade despótica?

As tiranias perderam seu líder e ganharam a Hidra de Lerna.

Alerta-se, então, para a possibilidade de enclausuramento dos indivíduos pelas estruturas infotécnicas não como uma hipótese de roteiros cinematográficos, mas como preocupação de parte da comunidade estudiosa das tecnologias sociais.

Para ninguém menos que Wolton, "o risco de desenvolvimento de uma concepção menos democrática da informação tendo por base uma especialização por nível de conhecimento e capacidade financeira é real." (Wolton, p. 93) Ou seja, quando os filtros passam a entregar excessivamente aquilo que o usuário tem como características marcadas pelos bancos de dados e estruturas de memória, é o imperativo da verticalização que se dará através de conteúdos altamente segmentados atrelados a sua forma de agir/reagir nos 
ambientes - não apenas digitais - e sua condição financeira, ainda mais levando em conta os usos mais comuns na contemporaneidade deste tipo de filtro e construção de perfis que está se aplicando em grande escala nas estruturas de comunicação jornalística e publicitária.

Ainda em Wolton, o problema que pode ruir a potência do imaginário contra a estupefação determinista das ideologias está presente nas estruturas hegemônicas que fazem parte desta análise.

[...] um dos efeitos da dominação sociocultural é justamente o de pedir só o que se tem. Desejar outra coisa, empreender, já é se colocar em uma atitude dinâmica de questionamento, de emancipação. O risco é que haja um lugar para cada um, mas cada um em seu lugar! (Wolton, p. 94, grifo nosso)

Desta forma, como destacado acima, o filtro é conformador, está no campo das ideologias mais do que no imaginário. "No fim das contas, a ideia de 'dar às pessoas o que elas querem' é uma filosofia cívica frágil e rasteira. No entanto, o surgimento da bolha dos filtros não afeta apenas o modo como processamos as notícias. Pode também afetar o modo como pensamos." (Pariser, p. 71)

A panspermia infotécnica pode ser subjugada pela lógica do capital que está a cercar o internauta, e logo mais o indivíduo, e note-se que aqui se deixou temporariamente de chamálo de sujeito, para atacá-lo, assediá-lo com suas estruturas de cooptação. A economia, a vida anestesiada em troca da reprodução do sistema. "Na era da indústria cultural, o indivíduo não decide mais automaticamente: o conflito entre impulsos e consciência é resolvido com a adesão acrítica aos valores impostos [...]”. (Wolf, p. 77)

Enquanto no florescimento da internet muito se falou de modo ufanista sobre suas características libertárias, a cibernética wieneriana está no âmbito do controle desde suas primeiras linhas de código.

Mas neste momento, o que se percebe é a aceitação da ultrassegmentação de entregáveis infotécnicos que deflagram para os olhares atentos as estruturas violentas sutilizadas pelos discursos comodistas da satisfação ágil e imediata. E nesta medida, a estrutura financeira e a satisfação anestésica estão ambas operando na instância do capital em uma sociedade tecnicizada.

Os dois perigos são então a seleção pelo dinheiro e a segmentação dos conteúdos em função dos meios sociais. É nisso que os jornais, as rádios e as televisões - e apesar das críticas das quais são objeto - se revelam ser mais democráticos. Eles são os instrumentos de comunicação que atuam no universal e não no particular. (Wolton, p. 94) 
O que antes já foi chamado de símbolo da massificação, baseando-se em Wolton, poderá ser o caminho de resguardo do enclausuramento dos ciberguetos.

Corso dá sinais de que de qualquer forma a tecnologia atua e poderá atuar na contracorrente das hegemonias por permitir a manifestação de muitos.

A tecnologia potencializa a dimensão dos dispositivos de controle e a relação entre sujeito e vigilância é característica básica da cibercultura, pois esta questiona poderes centralizadores e permite a liberdade de informação não apenas nas redes digitais. (Corso, p. 8-9)

Por outro lado, ao pensar em seu argumento pelo prisma triviniano, o espaço para a resistência está comprimido por um tempo acelerado. As estruturas físicas de tempo e espaço estão dadas na velocidade da cibercultura e este poderá inclusive chegar à suspensão à medida que cada indivíduo se apresente como reprodutor do imperativo da dromoaptidão para que seja também seu vigilante.

Atividades de vigilância voltadas para indivíduos ou populações humanas envolvem, de modo geral, três elementos centrais: observação, conhecimento e intervenção. A observação pode ser efetuada de diferentes modos [...] e implica a inspeção regular, sistemática e focalizada de indivíduos, populações, informações ou processos comportamentais, corporais, psíquicos, sociais, entre outros. Ela deve, ainda, permitir a produção de conhecimento sobre os vigiados, o que pode ser formalizado de diversas formas (extração de padrões, regularidades ou cadeia causais, por exemplo). Ou seja, as informações apreendidas pela observação devem ser convertidas em conhecimento a respeito daqueles sob vigilância, de modo a permitir agir sobre suas escolhas, subjetividades, comportamentos. Aí reside o terceiro e último elemento. Nem a observação nem o conhecimento que dela derivam se caracterizam como vigilância se não houver a perspectiva de intervir sobre os indivíduos ou populações em foco. (Bruno, p. 18)

A vigilância, então, está posta nestes termos apenas na medida em que tem em seu terceiro ponto elementar a intervenção.

Se a coleta de dados invasiva, pervasiva e, de modo cibercultural e dromoadaptativo, evasiva das redes sociais pudesse ser ignorada nos sistemas mais estritos de vigilância, o estudo do Facebook apresentado há pouco reduz este argumento de modo drástico.

Os autores Alves e Rodrigues trarão à baila a questão da veracidade dos enunciados, com Base em Dodebei e Gouveia para indicar um ponto importante no deslocamento entre passado e presente.

Dodebei e Gouveia apontam o deslocamento da relação passado-presente para a relação passado-presente-futuro na preservação do conhecimento, cujo processamento contínuo de novas informações é o mesmo que possibilita a fusão, complementação e descarte de informações da memória, tornando difícil o resgate dos formatos originais de ingresso, motivo pelo qual as memórias geridas e gerenciadas não podem ser tomadas mais como banco de dados (informação), mas sim como centros de conhecimento, cuja informação é processada em seu interior, o que para Latour implica na intersecção de conhecimentos. (Alves, p. 87) 
Assim, pergunta-se se o presente torna-se efêmero, se se converte em passado rapidamente, e se este passado é presentificado, ao mesmo tempo, o objeto que dissimula o poder pode não estar nem no passado, nem no presente, mas na efemeridade que se dissimula e dá os traços passados ao presente e presente ao passado.

Este ambiente de comunicação se converte, a cada dia, em uma ferramenta ainda mais poderosa de coleta de dados e categorização do passado e presente, do tempo sem tempo, disponível instantaneamente na memória dos dados.

A maior parte de nossas ações cotidianas no ciberespaço são facilmente rastreáveis e nossas informações passam a fazer parte de diferentes bancos de dados que grande parte desconhece (ou desconhecia, devido à grande quantidade de indícios e revelações sobre tal) (Santos e Nicolau, p. 5)

A exemplo da dificuldade de conhecer todas as formas de monitoramento está disponível no noticiário global de forma recorrente as reportagens feitas com dados do Wikileaks que indicam espionagem entre nações. Se até os estados nacionais estão enfrentando dificuldades para manter suas informações sigilosas, o usuário comum a internet acaba por entregar todos os seus dados identificadores de modo a ser difícil traçar um caminho de volta para o encerramento do uso de tais dados.

Não que esta seja uma prática recente, já que inúmeras empresas contratam os serviços de empresas de dados para "enriquecer" ou lavar os seus dados de clientes. Na prática isso significa que há anos as empresas fornecer dados simples como e-mail, telefone, nome completo ou CPF/RG de seus possíveis clientes e as empresas de dados devolvem o documento com informações complementares, como endereço, perfil de consumo etc.

Voluntariamente ou não, as pessoas estão se tornando prisioneiras de redes telemáticas que permitem saber, por quem conduz o processo e ou paga pela informação, cada vez mais a respeito de sua identidade, relações, desejos e movimentos. Queiramos ou não, estamos nos tornando fornecedores de informações que podem ser coletadas, reunidas, analisadas, vendidas e exploradas como propriedade de organizações e indivíduos sobre as quais temos muito pouco conhecimento e praticamente nenhuma autoridade. (Rüdiger, p. 46)

\section{OBSOLESCÊNCIA E MEMÓRIA}

Um ponto nevrálgico a ser considerado é, então, justamente a velocidade acelerada de renovação e aprimoramento das tecnologias de comunicação e dados frente à velocidade reduzida (e necessariamente reduzida) dos debates sobre os aspectos éticos e morais que resultam dos usos tecnológicos.

Another reason why so much of today's Internet censorship is invisible is because it's not the governments who practice it. While in most cases it's enough to block 
access to a particular critical blog post, it's even better to remove that blog post from the Internet in its entirety. While governments do not have such mighty power, companies that enable users to publish such blog posts on their sites can do it in a blink. Being able to force companies to police the Web according to a set of some broad guidelines is a dream come true for any government. (Morozov, p. 101)

Mas na mesma medida que se discute vigilância, discute-se o esquecimento e a memória. Assim, a força do Estado em dizer quem cada cidadão deve ser, que papel desempenhar, gradativamente foi sutilizada para ser ocupada por núcleos rizomáticos de entretenimento e conforto.

Os algoritmos distribuem seus benefícios e dispersam sua vigilância.

A mão pesada do Estado passa a ser substituída pelo toque suave de uma mão ainda mais potente.

Se as ideologias da salvação do século XX deixaram marcas de guerra e mortes, a economia do século XXI não deseja baixas. A morte não produz capital. O encerramento não perpetua a cibercultura. E então nem tempo nem sujeito morrem.

Ao mesmo passo, assim, que se perde o tirano que se combate em sua imagem, dissipando-o entre diversos pontos de controle e vigilância, atenua-se a percepção de que algo ainda precisa ser combatido, ainda mais quando o entorno comunicacional está a oferecer mordomias a cada indivíduo. No início do século XVI, La Boétie já advertia para o povo ignorante, que ignora, que desconhece a fundo os traços que o subjugam, indicando sua rápida aceitação das estruturas que o diminuem.

Esta é a inclinação natural do povo ignorante, cujo número é cada vez maior nas cidades: desconfia daquele que o ama e acredita naquele que o engana. [...] É realmente assombroso ver como se deixam ir tão rapidamente ao menor afago que lhes seja dispensado. (La Boétie, p. 56)

Este comportamento é perceptível em uma visão econômica presente na obra de Mayer-Schönberger, que, na mesma medida que esquecer tornou-se mais caro do que lembrar, e por isso aceitamos a memória, o banco de dados infindável, aceitamos os afagos doces e fáceis do que a batalha colossal para descer às bases das estruturas sociais e de constituição da identidade e da livre constituição do sujeito. "Today, with the help of widespread technology, forgetting has become the exception, and remembering the default." (Mayer-Schönberger, p. 2)

Este ponto, muito caro ao autor, está posto para dar início ao debate sobre qual é a real transformação que está se operando no âmbito sociológico das tecnologias da comunicação e informação. 
Esta mudança citada por Mayer-Schönberger é profunda. Ao longo de sua obra, será a viga mestra que conduzirá seus estudos indicando que por toda a história da humanidade, o desejo de apreender a realidade em palavras, em pinturas, objetos, e letras nos tempos mais recentes estava atrelado à fugacidade dos acontecimentos.

A tentativa de consolidar a memória em artefatos de memória sempre foi um esforço custoso e pouco eficiente, abrindo margens para interpretações diferenciadas, dúvidas, lembranças, imaginação.

Já o esquecimento sempre seguiu a corrente entrópica da degradação da informação, da memória, do passado. Em suma, o acontecimento presente estava mais próximo de sua extinção do que de sua perpetuidade.

As práticas de cibercultura, apesar de conservarem uma abertura, são parte de um processo histórico bem determinado, cujo fundamento é econômico e seu sentido é tentar nos assegurar o controle e a exploração do conjunto da existência em sua totalidade. (Rüdiger, p. 119)

Rüdiger então percebe a questão do controle da existência através das estruturas da cibercultura em uma fala que pode ser apropriada justamente para tratar da memória e do esquecimento em um viés econômico.

Storing information has become fantastically convenient, but its more than convenience that induces us to preserve. The truth is that the economics of storage have made forgetting brutally expensive. [...] With such an abundance of cheap storage, it is simply no longer economical to event decide whether to remember or forget. Forgetting [...] has become too expensive for people to use. What is true for personal storage applies equally to corporate storage. (Mayer-Schönberger, p. 68)

Mas enquanto Pariser e Mayer-Schönberger vão olhar para a inversão do padrão entre lembrança e esquecimento nesta economia, no custo, na praticidade, na facilidade, Palácios vai dizer que o excesso de arquivos e estruturas de memória pode ser também derivado de um tempo sem tempo.

[...] talvez não haja paradoxo algum, mas sim uma consequência: a velocidade de nossos tempos é de tal ordem de grandeza que nos sentimos compelidos a guardar as imagens do presente para uma visita posterior, num futuro mais calmo, que teimamos em sonhar que virá a existir. Tal e qual fazem os turistas ao clicar desesperadamente suas câmeras fotográficas durante suas viagens, produzindo milhares de imagens que, muito provavelmente, ficarão esquecidas, porém estocadas, em algum HD ou cartão de memória na volta das férias. Imagens que, diferentemente da perenidade das marcas nas pedras de nosso ancestral neolítico, ou mesmo dos álbuns fotográficos de nossos pais, são tremendamente vulneráveis a apagamentos de todos os tipos, sejam os tecnológicos, sejam os do esquecimento puro e simples, que tão centralmente quanto a lembrança faz parte do trabalho da memória. (Palácios, p. 48)

O enfrentamento de uma sociedade anestesiada através de conteúdos satisfatórios e confirmatórios é um preço alto a se pagar, isso quando esta opção é percebida, para manter a 
hipermemória em forma hiperacessível. Neste sentido, há ainda aquele que mal se deu conta que seu universo está submerso em uma estrutura de dados que exerce sobre ele uma influência silenciosa, desconhecida.

O duplipensar de Orwell só pode ser praticado por quem enxergou a teletela e a quem foi ensinada a novilíngua.

O panóptico muda a conduta de quem o enxerga. Mas a mão invisível de Adam Smith agora opera pelo capital em um âmbito verticalizado, tocando as mentes sem dar-lhes muitas chances para perceber suas cicatrizes. Cada corte, cada violência da cibercultura é cicatrizada com golfadas lúdicas e com performance de mágicos e ilusionistas da imagem espetacular.

O gesto rápido tira a atenção do que importa, do operador, do vigilante.

Um bom exemplo é perceber como duas grandes empresas ligadas ao mercado de dados se posicionam.

O Google tem como objetivo principal responder a perguntas; a missão do Facebook é ajudar as pessoas a se conectar com seus amigos. A questão é que a base dos dois negócios é essencialmente a mesma: publicidade direcionada, altamente relevante. (Pariser, p. 41)

Ainda que o autor apresente a missão organizacional, ou seja, aquilo que deve ser o resultado último da atividade empresarial, isso não esclarece a metodologia aplicada para conquistar tal objetivo.

Assim, mesmo tendo objetivos diferentes, a metodologia de ambas as empresa, e de tantas outras no mercado, é similar: tratamento de dados e construção de algoritmos sofisticados que possam aprender de acordo com seu uso.

Na mesma seara estão empresas como a Microsoft, Sony, Ubisoft (criadora de jogos como o famoso Assassin's Creed que utilizar inteligência artificial para oferecer uma experiência de jogo diferenciada para cada jogador); Rubicon Project (empresa de automatização de publicidade baseada em dados de internautas, assim como a Acxion).

Para entender o que significaria este aprisionamento, Pariser segue indicando que "o aprisionamento [tecnológico] é o ponto no qual os usuários estão tão envolvidos com a tecnologia que, mesmo que um concorrente ofereça um serviço melhor, não vale a pena mudar." (Pariser, p. 41)

Neste sentido, ao adaptar este aprisionamento para as redes de dados, há um patamar crítico que é a incapacidade de saber quais são os bancos de dados que ainda guardam informações pessoais e os caminhos para solicitar efetivamente sua retirada. 
Outro ponto crítico vem a ser o ganho e a perda, na sociedade atual, ao solicitar a remoção dos rastros digitais, se isso fosse realmente possível.

Esta balança pende em função de pesos não bem definidos e variados.

Não ser conhecido pelo Google pode significar a indigência digital nos dias atuais, mas num futuro próximo, pode ser além de uma exclusão tecnológica, uma marca sofrível de inaptidão dromocrática cibercultural e uma barreira de socialização.

Desde o século XVIII, como vimos, a informação no Ocidente em por base uma concepção que coloca no centro o indivíduo e a democrática. É em nome da liberdade e da igualdade os indivíduos que a informação, e qualquer informação, deve ser acessível a cada cidadão, como meio de conhecer a realidade e de agir. Ela é indissociável de uma ideia de igualdade e de universalidade. É uma concepção essencialmente política, que não tem outra legitimidade que um sistema de valores próprios a uma cultura, a do Ocidente. (Wolton, p. 93)

É este antropocentrismo que pode ter colocado em termos correntes as visões de Lévy sobre as potencialidades positivas da rede em patamar mais destacado do que os riscos atrelados a qualquer tecnologia.

As tecnologias de comunicação contemporâneas conectadas à rede de dados acabam por estar integradas com a estrutura socioantropológica na medida em que não se faz simples a separação do antropológico, sociológico e suas tecnologias.

Neste contexto, Wolton ainda indicará um descompasso que se vê ainda nos anos posteriores a sua obra no que tange as funções da internet, por ele chamada de rede, ou Net.

Os três tipos de funções coabitam em proporções diferentes na Net, mas eles não
vão na mesma direção. A função de informação remete ao que é necessário ao
funcionamento de uma sociedade complexa; a expressão exprime a necessidade de
falar, em uma sociedade livre, mas povoada de solidões, a comunicação implica a
dificuldade de intercompreensão. Pode-se assim contrapor a velocidade da
informação com a lentidão da comunicação. (Wolton, p. 95 - 96)

Esta visão da tripla base da internet indica sua relação intrínseca mas, de modo diferenciado, mostra a possibilidade de agirem em sentidos diferentes.

Quando o autor mostra claramente que informar não apenas é algo diferente de se comunicar, mas também com tempos próprios, coloca o tema na mesma pauta de Trivinho, para quem a velocidade e aceleração fazem parte do desenvolvimento humano desde seus primeiros passos conscientes, mas que nos dias atuais toma formas extremas, extirpando do indivíduo o tempo do pensamento e da reflexão.

Assim, o que hoje se referencia como aplicativos de comunicação poderiam, nesta perspectiva, ser considerados como incorretamente rotulados na medida em que estão mais 
profundamente circunscritos na informação, na agilidade das respostas, do que no tempo das reflexões.

A agilidade corrói, então, a comunicação na sua constituição temporal em detrimento do imperativo do contato direto, constante e imediato.

Esta mediação necessária para formar um juízo de valor sobre os processos comunicativos pode acabar sendo posta em segundo plano para que não comprometa, como exige a cibercultura, a celeridade no retorno, no fluxo, na continuidade do processo que sustenta a urgência de qualquer questão, das mais ínfimas às mais importantes da sociedade.

Em uma análise breve de um segundo exemplo, referencia-se novamente o caso da campanha que agradece as "curtidas" dadas por milhares de pessoas nas páginas humanitárias do Facebook mas lembra que este "like" não está mudando a vida das pessoas que estão em estado de vulnerabilidade.

O envolvimento, em alguns casos, resume-se a clicar para "curtir" um tema sensível sem que isso signifique um posicionamento realmente político ou crítico sobre as estruturas que mantém as desigualdades ou as violências contemporâneas.

Ainda assim, sendo o envolvimento ou o referenciado engajamento, já uma questão que Wolton colocará em relevo para indicar que, a seu tempo, a internet não estaria em condições de ser considerada uma mídia efetiva, não por suas características físicas ou eletrônicas, mas pela forma como o público, ou melhor, a imagem que se precisa construir sobre o público de cada mídia.

Enfim, não há mídia sem uma representação a priori de um público. [...] Um jornal, assim como uma emissora de rádio ou de televisão, supõe uma intenção - alguns dizem uma construção a priori do público -, o que explica a diferença da sedução da Net cuja utopia consiste, ao contrário, não construir a priori esse público, uma vez que pode estar em qualquer lugar do mundo. (Wolton, p. 97)

Para Wolton, a categorização de estruturas infotécnicas como mídia passa pela representação, a priori, de um público. Nas palavras exatas, Wolton traz que "a existência de uma mídia remete sempre à existência de uma comunidade, a uma visão das relações entre escala individual e escala coletiva e uma determinada representação dos públicos." (Wolton, p. 98)

Este apontamento é relevante na medida em que o próprio autor indica, em sua obra datada do início dos anos 2000, que a internet estaria em outro patamar distintivo, pelo qual seria duvidosa a sua classificação justamente pela indefinição, a priori, do que viria a ser o seu público, sendo espaço múltiplo de sujeitos variados. 
Acontece que, com o conhecimento atual, a internet ainda mantém seu gérmen de multiverso, mas o público, antes indefinível, agora passa a ser altamente rastreável, rotulável e categorizável.

Assim, o ciberespaço de ciberagentes anônimos deu lugar a uma estrutura de cruzamento de dados tão engendrada e articulada que buscará a identidade maquínica de cada indivíduo inclusive em traços comportamentais, no modo como um mouse é conduzido pelo texto, cruzado com a região de acesso e os tipos de conteúdo em leitura.

Sem grande aviso ou estardalhaço, o mundo digital está mudando em suas bases. O que um dia foi um meio anônimo e que qualquer pessoa podia ser quem quisesse no qual, nas palavras de uma famosa charge da New Yorker, 'ninguém sabe que você é um cachorro' - transformou-se agora numa ferramenta dedicada a solicitar e analisar os nossos dados pessoais. (Pariser, p. 11)

Se no tempo de Wolton o anonimato era comum nas redes, em sua atualização, ele estaria apresentado como possibilidade, a muito custo, de contra-corrente e rebelião ativa e custosa, servindo de contra-violência da microvigilância em larga escala.

E esta classificação pode perseguir um indivíduo por tempo indeterminado, implicando em barreiras que mal suspeite, como o encarecimento de seguro de vida por análise comportamental da empresa de seguros.

Quanto Boétie trata, em sua época, da tirania ou do controle, vai trazer um pensamento que se aplicará, da mesma forma, aos dados. “[...] refletindo bem, é a maior desgraça estar sujeito a um soberano de cuja bondade nunca se pode ter certeza e que tem sempre o poder de ser mau quando quiser. E ter vários senhores é ser tantas outras vezes extremamente infeliz." (La Boétie, p. 31)

A questão que se coloca é se a soberania dos Estados Nacionais ainda prevalece sobre a soberania do ciberespaço, já que esta segue cooptando corporações e governos para manterem o imperativo da dromocracia e da coleta de dados com rédeas se não soltas, ao menos frouxas.

Em outras palavras, a vigilância e as estruturas de algoritmos podem ter invertido o pensamento woltoniano pelo qual, a princípio, a internet não se enquadraria propriamente na categoria de mídia, pela incapacidade inicial de pensar a priori um público, se não todos os públicos sem fronteiras, tornando-se, nesta inversão, a supermídia, pela qual não só o público é identificável a priori quanto seus passos podem ser considerados antes mesmo de serem praticados, e não só no nível de grupos de interesse, como públicos racionais, mas de acordo com as respostas de indivíduos específicos. E indo além, com os dados da supermídia, não 
apenas o público é conhecido (já não mais apenas imaginado) quanto está sob a coerção suave do assédio publicitário, para citar um exemplo, de alta performance baseado no comportamento de seus iguais.

Neste sentido, o autor reconhece a força mercadológica da internet mas sustenta, em seu tempo, que em si não a consideraria uma mídia como tal, justificando exatamente a ausência do juízo a priori do que viria a ser seu público, de modo a colocar, ao menos inicialmente, o peso do mercado sobre este viés, porém ainda pouco atado à visão de vigilância que se desenvolveria alguns anos após sua escrita.

Em outros termos, atualmente há um engano sobre a significação profunda da Net. Considera-se a dimensão de comunicação livre, sem restrições, um espaço de liberdade em relação a todas as pressões que restringem as mídias clássicas, enquanto o essencial de sua inovação não está aí, mas, sim, no estabelecimento de sistemas de informação comerciais de todo tipo. Quanto ao que é essencial a Net não é uma mídia. É um formidável sistema de transmissão e de acesso a um número incalculável de informações. (Wolton, p. 99)

Esta perspectiva ainda está muito próxima à internet com poucos indexadores relevantes, que possuía dificuldades crônicas à época para organizar seus dados de modo simplificado. Na mesma medida, a digitalização dos media começava a mostrar seus contornos, mas a convergência prevista nos dias atuais toma a largo o que se supunha por muitos no início da década passada.

Em outros momentos de sua obra, Wolton chegou, como presente neste trabalho, a indicar inclusive, com seu vislumbre sobre a pressão e o discurso hegemônicos e seu assédio aos indivíduos, que os meios de comunicação ditos "tradicionais" como a televisão, o rádio e o jornal seriam, então, a alternativa para o enclausuramento vertical do indivíduo na internet.

Os meios de comunicação universais que tem seu público imaginado como o sujeito médio seria a escapatória a um fechamento dos acessos a conteúdos pouco diversificado e conformadores.

De forma alguma há de se pensar, todavia, que em Wolton há um pensamento de recepção acrítica e determinista das informações, porém é evidente o peso do tripé que considera não apenas a informação, mas também a expressão e a comunicação para a constituição da internet, sem necessariamente vincular a expressão a uma obrigatoriedade crítica. Ela pode estar presente, mas não está pressuposta.

Em Silva (2012) chega-se a indicar que o caminho de resistência a este enclausuramento estaria no campo do imaginário, no campo das divergências, dos desvios. “O imaginário é, ao mesmo tempo, uma fonte racional e não racional de impulsos para a ação. $\mathrm{O}$ 
imaginário social instala-se por contágio. [...] no imaginário há sempre desvio.” (Silva, 2012, p. 13)

Então, claramente no imaginário as estruturas de controle falharão, pelo desvio, mas se este imaginário estiver cooptado pela satisfação anestesiante, parte de sua função seminal pode estar sublimada. O imaginário desviante pode ser o caminho para a manutenção de um eu não homogeneizado.

Neste compasso, tem-se que

Em um universo totalizado, centrado, concêntrico, já não existem possibilidades excêntricas. Por toda parte, instituem-se processos paralelos, sociedades paralelas, mercados paralelos. A integração produz necessariamente zonas excêntricas, para o melhor e para o pior. (Baudrillard, p. 18)

É, então, retirado do trecho de Baudrillard que mesmo nas totalidades, nas clausuras, há o seu oposto, sua contracorrente. A dromoaptidão exercerá sua pressão mas na medida em que suas marcas passam a ser sentidas, podem também receber resistências. A internet vigiada está, cada vez mais, se contrapondo ao Tor, o software de comunicação anônima na rede, por exemplo. A agilidade das trocas simbólicas pode estar se contrapondo à espiritualidade e meditação, apenas para pensar um contraponto. Mas ainda assim, mesmo experiências que em outros tempos tinham contornos mais profundos, como a volta ao mundo, acabam cedendo muitas vezes ao imperativo da comunicação e publicação constante de cada etapa, cada passo, inserindo ali seu viés de velocidade comunicativa, base para a interlocução legitimada na cibercultura.

O valor da rede em que cada um se insere pode assumir grande relevância no que viria a ser o capital simbólico e de poder nas sociedades cibernéticas. Estar fora das redes sociais e dos indexadores e buscadores pode significar não existir para a sociedade média.

Assim, seria excluído este indivíduo não por que não existe material e organicamente, nem por ser inoperante no campo produtivo fabril, por exemplo, mas por não produzir as informações e os dados de modo a ser um elo identificável e comercializável dentro do imperativo dromoapto.

Para cada indivíduo, estar na sociedade cibercultural é garantir a todo custo, a todo tempo, que segue sendo um ente vendável, com valor comercial e com agilidade informativa, não necessariamente comunicativa.

Se os rastros digitais são extremamente sutis, sua existência comunicativa passa a ser pouco relevante para os indexadores (sejam em buscas, sejam em redes sociais), levando a 
bolha de filtro a excluí-lo por um período indeterminado. Em outra via, não significa que o capital tenha abandonado este indivíduo pelo simples fato de deixar poucos rastros.

A pressão social exercerá ao máximo sua força a fim de compeli-lo a ingressar ativamente no ecossistema infotécnico da cibercultura. Cada nó, neste caso, inclusive, cada sujeito conectado/constituído na e pela cibercultura usará sua energia dentro da rede para reforçar sua dominância, sua relevância em meio aos grupos.

E isso se faz incluindo na base os sujeitos menos aptos, não por compaixão, mas para que a antiga segregação de castas permaneça evidente. O mais apto, o mais adaptado será, neste caso, as batatas de Quincas Borba. Sem a base minimamente empoderada.

Em um paralelo breve, tem-se em conta que em dado momento esta aptidão pode também ser da máquina em cooptar o sujeito pela praticidade e conforto. Para o diretor do Google, Eric Schmidt, chegará o dia em que "a tecnologia vai ser tão boa que as pessoas terão muita dificuldade em assistir ou consumir qualquer coisa que não tenha sido minimamente adaptada para elas." (Schmidt apud Pariser, p. 47, grifo nosso). Questiona-se, então, o juízo de valor feito por Schmidt, já que ao indicar que a tecnologia será suficientemente "boa" a ponto de se tornar uma barreira para que as pessoas consumam algo que não tenha as suas próprias características. A serendipidade pode estar comprometida em contextos de alta cibridização.

Assim, a dúvida recai sobre a compreensão do executivo sobre os aspectos técnicos e sociais. De outra forma, esta dúvida pode ser traduzida pela indefinição se a tecnologia chegará a ser tão detalhista (boa) que levará a este cenário, ou se através da tecnologia, este "bem" será entregue à sociedade, que terá conflitos com a alteridade.

Em tintas mais enfáticas, se velocidade é, necessariamente, violência, [...] a
dromocracia cibercultural, como não poderia deixar de ser, é, em essência, terror
[...] - aqui já não tanto pelos nexos imanentes entre velocidade e processo bélico ou
em razão de a velocidade implicar-se na espiral da morte simbólica (da geografia, do
corpo, da alteridade concreta etc.). A condição dromocrática da cibercultura exige
que a violência high tech seja introjetada e 'atuada': a dromoaptidão em relação às
senas infotécnicas de acesso (ao mercado de trabalho, ao cyberspace, ao lazer
digital, à alteridade virtual etc.) deve-se converter em habitus, modo de ser, de estar
e de agir diuturnamente reconfirmado até a simbiose imaginária e o acoplamento
corporal com o vetor implicado consolidarem o automatismo subjetivo e prático
requerido. O ideal cínico da cibercultura é o Homo velox com a consciência feliz e
despreocupada do Homo ludens. Dessa maneira, a violência da técnica avançada
adquire, de tão invisível, o ar que lhe talha a sofisticação e a imunidade que também
a redime de todo questionamento público." (Trivinho, p. 75 )

O indivíduo que não se adapta, que não se torna dromoapto, sofrerá as pressões da ciberexclusão, mas mesmo o dromoapto precisará se esforçar para não se tornar obsoleto. 
Não saber, não lembrar, nos dias atuais, pode ser o mesmo que não ter acesso à internet e ao Google.

Todos "sabem" aquilo que o Google mostra. De um instante para o outro pode-se se "saber" qual é a lista de países de cada continente em ordem alfabética, ou por PIB. Pode-se ter acesso rápido à dieta mais indicada para um gato diabético ou como construir uma mesa de centro usando paletes.

Todos "lembram" com mais facilidade aquilo que é encontrável pelas estruturas infotécnicas de memória e esquecem sem muitos protestos aquilo que não está comprovável pelos artefatos de memória presenteísticos.

Segundo o psicólogo George Lowenstein, a curiosidade é atiçada quando nos vemos diante de um 'lacuna de informações'. É uma sensação de privação [...]. No entanto, para sentirmos curiosidade, temos de estar conscientes de que algo está sendo escondido. Como a bolha dos filtros esconde o conteúdo de forma invisível, não nos sentimos compelidos a aprender sobre o que não sabemos. (Pariser, p. 83-84)

Por mais que o tema de Pariser esteja circunscrito na questão dos filtros algorítmicos referentes à customização no momento da citação acima, seu pensamento pode ser transportado para a outra face do debate em torno das redes de memória e curadoria digital. Que sujeito, então, ainda na visão pariseriana, está se constituindo dentro dos filtros algorítmicos.

Mas esta visão ainda precisa ser acrescida da vigilância pantópica que, sob os reflexos da síndrome do observado, acaba por alterar o sujeito em seu momento presente pela simples ciência da vigilância e do filtro. As estratégias para conduzir os filtros de plataformas virtuais a categorizarem seu acesso seguindo um dado interesse individual, por si só, impacta a dinâmica tanto de ação quanto de pensamento e constituição deste sujeito.

Se o foco recair não apenas na memória de um, mas na memória de muitos, poderia se falar de memória coletiva e dos impactos da memória infotécnica em suas estruturas.

Ainda que haja muitas definições para a memória coletiva, há de se considerar que a sociedade contemporânea está no desabrochar do que virá a ser a memória baseada nos dispositivos infotécnicos, o que dificulta tanto a sua visualização clara quanto a sua compreensão mais aprofundada a ponto de defini-la de modo certeiro.

Given the fascinating, yet unorganized state of collective memory studies, it would be premature - and probably quite misleading - to try to provide precise definitions. To do so would involve implicit and unexplored assumptions and create a kind of rigid formulation that almost begs for objections, many of which would be legitimate. Instead, I shall begin by outlining a couple of basic oppositions that define the conceptual field within which collective memory is discussed. At some 
point in the future clear, widely accepted definitions may be possible, but for the present, providing a map of the conceptual field is a more modest and appropriate path to follow. (Wertsch, p. 85)

Da mesma forma, a dificuldade de compreender como será a memória coletiva marca a mesma barreira que leva às dúvidas sobre o futuro do esquecimento e suas tonalidades.

Memória coletiva, por outro lado, poderia ser entendida como a "lembrança de um grupo que vive certos acontecimentos em comum" (Bernardo, p. 100), o que indica que há valores e artefatos de memória compartilhados e que os membros do grupo participam da rememoração. Importante ter em mente que este processo de rememoração não está incólume dos riscos inerentes à maioria dos suporte de memória, a saber, a obsolescência e a entropia, e mais do que isso, à ressignificação presente o que fora passado. Mas além disso, sofrem, então, clara influência do momento presente, momento da rememoração, sem contar nos diversos agentes que interferem nas relações de memória, como a mídia.

Esta relação entre grupo e memória passará pelas controvérsias e tentativas de chegar a uma conclusão momentânea para o discurso sobre o passado. É isso que a autora apresenta ao dizer que

[...] o trabalho da memória não traz para o presente os fatos como realmente ocorreram. As lembranças de determinados acontecimentos dependem de inúmeros fatores: desde o lugar que indivíduo ocupa na hierarquia social, até como se encontra a vivência do presente. (Bernardo, p. 101)

Mas quando a tecnologia digital faz parte deste discurso, os artefatos comprobatórios atuam em mesma medida para guiar a memória e para cerceá-la. É aquilo que está comprovado, visível, evidente. Não é aquilo que não se comprova.

Neste sentido, aquilo que está consonante com os filtros erigidos ao longo da coleta e classificação de dados terá seu viés crível.

$\mathrm{Na}$ bolha, a produção de conteúdo que valida o que já sabemos aumenta drasticamente. O que nos leva à segunda maneira pela qual a bolha é capaz de interferir com o aprendizado: ela bloqueia aquilo que o pesquisador Travis Proulx chama de 'ameaças ao significado', os eventos inquietantes e confusos que alimentam o nosso desejo de entender e adquirir novas ideias. (Pariser, p. 82 - 83)

Da mesma forma que aquilo que a bolha reforça também é aquilo que ela oculta.

O esquecimento está não na impossibilidade de existir uma informação, mas na impossibilidade de acessá-la ou ao menos no alto custo para ter acesso a ela, e por custo não se deve limitar o entendimento como sendo valores monetários apenas, mas também o investimento em tempo, dedicação e conhecimento. Sobre este tipo de filtro e a forma como ele impacta a serendipidade é dito por Pariser, quando afirma que "o Google é ótimo para 
encontrarmos o que sabemos que queremos, mas não para encontrarmos o que não sabemos que queremos" (Pariser, p.95)

Questiona-se, então, se a bolha infotecnológica pode seguir como um filtro tão eficiente sem abater parte da energia do próprio sujeito a quem a tecnologia deveria assistir?

Sobre a aceleração das obsolescências e o imperativo de estar sempre apto, ou como diria Trivinho, dromoapto, há de se compreender que há não apenas um aspecto de velocidade, mas também um viés econômico (em valores, tempo, dedicação etc., como citado anteriormente) no processo de incorporação das tecnologias que precisa ocorrer recursivamente, garantindo que o fluxo de atualizações de linguagens, ferramentas e tecnologias responda à mesma regra de acelerações.

A reboque, os indivíduos seguem correndo em busca da dromoaptidão que será, neste momento, sempre transitória, ou ao menos temporariamente reconhecida. Novamente, na dromocracia cibercultural, não há um indivíduo que seja dromoapto, conquanto no máximo estará dromoapto.

A nova lógica da desigualdade gira em torno do imperativo da dromoaptidão
propriamente cibercultural (ibidem, 2001, pp. 219-227; e, nesta obra, parte I,
capítulo 2; parte II, capítulos 2 e 4) como capital simbólico necessário para a
manifestação individual, grupal, empresarial e institucional no social em rede. A
capacidade de ser veloz abrange a competência econômica orientada para a posse
privada plena (isto é, com base no domo) das senhas infotécnicas de acesso à época
(objeto infotecnológico e rede digital à frente), a competência cognitiva e
pragmática no trato da sociossemiose plena da interatividade (isto é, o domínio das
linguagens informáticas sempre em mutação) e a capacidade (econômica e
cognitiva) de acompanhamento da lógica da reciclagem estrutural daquelas senhas
(vale dizer, do movimento progressivo de otimização da mais potência de
hardwares, softwares e demais fatores informáticos, que compromete o que é
anterior em nome do que vem depois, ideologicamente valorado como sendo
melhor) (ibidem, 1999, parte I, capítulo 4; e, nesta obra, parte II, capítulos 2 e 3).
(Trivinho, p. 72)

Para pensar, então, a respeito dos debates sobre o direito ao esquecimento no âmbito jurídico brasileiro, por exemplo, é que em grande parte de seu corpo está dado por questões penais ou corporativas, mas os aspectos socioantropológicos mais amplos estão seguindo a reboque em passos diminutos. Ou seja, há um claro descompasso entre o tempo das tecnologias e o tempo da moral e ética humanas.

O uso das duas categorias, 'moral' e 'não-moral', sugere a inúmeros escritores do tema que os casos a serem investigados recaem em duas categorias nitidamente demarcadas e opostas. Como consequência, eles estruturam a sua discussão em torno dessa acentuada divisão. Nosso esboço intuitivo, ao contrário, sugere que na vida cotidiana encontramos, antes, um complexo espectro de casos, interrelacionados e sobrepostos de modos não apreendidos por nenhuma taxionomia dicotômica. [...] Parece, ademais, que na prática o que encontramos não é um contraste acentuado entre exigências absolutas e exigências que podem ser evitadas 
com facilidade, mas um continuum desordenado de exigências julgadas como providas de vários graus de força e inevitabilidade. (Nussbaum, p. 24 - 25)

Há ainda, nos dias atuais, mesmo com a ampla capacidade de armazenamento e processamento de dados, um perigo intermediário, se não paralelo.

Ao descrever as estruturas de big data, como já fora exposto, que figuram no cenário tecnológico como tecnologias de identificação comportamental e favorecer a comunicação altamente segmentada e massificadamente "individualizada", pode-se entender que esta fotografia ainda não está corretamente descrita.

Por mais que em casos específicos o volume de dados possa ser exorbitante para universos populacionais reduzidos, a prática atual de mercado, por exemplo, trabalha ainda hoje com amostras extrapoladas à mercê dos grupos de tratamento de dados.

Se hoje o problema pode não ser deveras evidente, em dado momento pode-se encarar um banco de dados histórico que poderá ser corrigido, reclassificado e utilizado sem que necessariamente cada indivíduo saiba o quanto está sendo influenciado pelos algoritmos, transformando o que se sabe ou se pretende saber sobre cada indivíduo.

A segmentação e classificação de perfis e grupos pode ter um efeito redundante e de reforço positivo, gratificando o indivíduo a cada ação consonante que ele praticar dentro do grupo em que foi inserido, mesmo sem ter clareza destes contornos.

Num primeiro tempo, este processo [categorização] foi considerado numa perspectiva cognitiva, diretamente ligada ao tratamento da informação. [...] Esse processo de categorização permite, pois, a decupagem do entorno, reagrupando os objetos que são ou que parecem ser semelhantes uns aos outros em certas dimensões (ainda que, em outras dimensões, poderiam existir grandes diferenças entre esses objetos). A categorização encontra então sua função no papel que ela desempenha na sistematização do entorno, sua decupagem e sua organização. Mas, se há sistematização da percepção do entorno, também há simplificação, isto é, as características dos estímulos devem poder ser modificadas para serem integradas às estruturas já existentes. De sorte que, através da categorização, as semelhanças ou as diferenças entre os objetos categorizados se tornam mais marcantes do que são na realidade. (Deschamps, p. 29 - 30)

Em outros termos, muitas pessoas estão sendo classificadas, catalogadas, etiquetadas com rótulos definidos por lógicas comerciais ou mesmo bélicas das quais elas mal têm conhecimento e que em alguns casos podem se tornar profecias autorrealizadas na medida em que o ecossistema midiático se adaptará aos rótulos dos indivíduos, e estes, cercados pelos conteúdos que lhe seriam mais apropriados, acaba por se acostumar e apegar à realidade comunicacional à qual foi circunscrito e passa a responder aos estímulos a ponto de não ser mais possível definir se houve um certo algorítmico ou se houve indução e contaminação por parte das estruturas comunicativas. 
Se a rede não esquece os dados que recebe, decidirá ignorar o dado obsoleto?

Por não escolhermos os critérios que os sites usarão para filtrar os diversos assuntos, é fácil intuirmos que as informações que nos chegam através de uma bolha de filtros sejam imparciais, objetivas, verdadeiras. Mas não são. Na verdade, quando as vemos de dentro da bolha, é quase impossível conhecer seu grau de parcialidade. (Pariser, p. 15)

Entre adequação de conteúdos aos interesses do usuário e adequação do usuário aos interesses dos produtores de conteúdos, pouco se tem clareza quando se está imerso em uma bolha de filtros sutil.

Esta equação não pode ser dimensionada pelo usuário comum, médio.

$\mathrm{Na}$ balança de disputas de poder, o indivíduo isolado segue como oponente fraco, sendo a cibercultura e, mais recentemente, a bolha de filtros pode acabar, segundo alguns autores, afastando as pessoas ao invés de aproximá-las.

Ou seja, se segregado o indivíduo mal pode contrapor ou sequer enxergar o viés dos algoritmos, a lógica majoritária pode estar levando a barreiras mais sutis de segregação, mantendo uma película espetacular que envolve parte da "realidade" com o discurso monofásico do conforto alienado.

Em uma sociedade filtrada, mesmo grande parte daqueles que se informam segue desinformada, pois olha notícia e mundo com o viés do filtro que carrega (ou que lhe carrega). Como já alertará Pariser, "[...] a bolha dos filtros é uma força centrífuga que nos afasta uns dos outros". (Pariser, p. 14). Por outro lado, ao analisar a cibercultura e a velocidade das comunicações, Trivinho indicará que Numa cifra metafórica, o processo se assemelha a uma mutação da derme
sociotécnológica da civilização contemporânea. E, seu desdobramento centrípeto, ao
mesmo tempo em que a interatividade se tornou o equivalente geral de relação e de
permuta - social, técnica, econômico-financeira, política etc. - com o mundo, a
sociossemiose que doravante a acompanha e lhe dá sustentação em escala
internacional acabou por vigorar como o equivalente geral das práticas sociais da
produção, armazenamento e transmissão/recepção de dados culturais. (Trivinho, p.
142)

Em outras palavras, a aproximação que se percebe nos dias atuais pode estar intimamente ligada às práticas de produção, armazenamento e transmissão, como destaca o autor, dos dados culturais, e como tal, também, da memória e do esquecimento que lhe convier, sem, novamente, que aqui haja uma conjugação volitiva ou mesmo ético-moral por parte da tecnologia e dos algoritmos. 
Longe de acreditar que as teorias da comunicação que remontam à bala mágica ou agulha hipodérmica tenham seu peso metodológico e prático estabelecido nos dias atuais, pois isso seria considerar o receptor como indivíduo vazio e sem capacidade crítica.

O ato de ver nunca é visão pura; o ato de ver é sempre moldado por um conjunto mais amplo de pressupostos e enquadramentos culturais e pelas indicações faladas e escritas que comumente acompanham a imagem visual e modelam a forma como as imagens são vistas e compreendidas. (Thompson, p. 21)

Se não há meios de enclausurar a percepção humana de modo determinista, por outro lado, não se consegue garantir neste momento que a liberdade ufanista de anos atrás esteja de fato mostrando sua melhor face nos dias atuais.

Quando entrevistei Jonathan McPhie, o principal responsável pela personalização das
pesquisas no Google, ele sugeriu ser quase impossível adivinhar como os algoritmos
moldariam a experiência de qualquer usuário específico. Assim, embora o Google
possa examinar nosso cliques de forma genérica, é muito mais difícil saber como o
sistema funcionará para qualquer usuário específico. (Pariser, p. 17)

Isso é o mesmo que dizer que por mais que quisesse, o Google, hoje, não tem meios de atuar sobre sua ferramenta de pesquisa para guiar um usuário único a um tipo de comportamento desejado e arquitetado de antemão, ou seja, seu código é agnóstico, não respondendo a interesses altamente específicos na seara social e mercadológica contra um alvo determinado e isolado.

Mas também, por outro lado, na mesma medida em que o filtro segue sem o viés de algum Grande Irmão que forjará os resultados para acompanharem uma certa ideologia, também o faz sem a possibilidade de que haja um acompanhamento ético específico e aprofundado sobre como o sujeito está sendo auto-enclausurado por suas escolhas, mesmo que não compreenda ou perceba a bolha do filtro se formando.

Se de um lado sequer os funcionários e gestores das ferramentas de busca na internet são capazes de prever o resultado específico da ferramenta nos dias atuais, como o usuário médio, padrão, poderá ser capaz de imaginar as formas de conduzir de modo consciente os caminhos pelos quais a sua bolha do filtro o está levando?

Ainda que se acredite haver esta dificuldade em alterar os resultados específicos de cada plataforma, um exemplo real pode ser elucidativo.

A jornalista Sheherazade, após abrir críticas à presidente Dilma Rousseff, alegou estar sendo vítima de censura que teria sido articulada pelo próprio Facebook.

A consciência de que a bolha se forme pode estar nos primórdios desta retomada de certa autonomia, mas ela, por si só, não basta. A mudança de conduta é profunda mas, de 
certo modo, terá que seguir às cegas justamente por ter que levar em conta algoritmos que são o centro diferenciador de mercado de cada empresa. "Sofremos uma brusca diminuição no alcance de nossa página e recebemos inúmeras denúncias de casos parecidos. Será que isso tem algo a ver com a visitinha da Presidente ao Mark Zuckerberg? \#CensuraPetistaDetected"16.

A matéria que referencia esta fala de Sheherazade já indica que claramente há uma declaração da rede Facebook indicando a queda no alcance das fanpages, mas o que é relevante para esta obra não é se de fato a Facebook interferiu, mas se ela pode interferir.

E para responder a esta questão, basta recordar do exemplo dado anteriormente sobre o estudo de contaminação social do humor realizado pela empresa em 2012 e publicado oficialmente no final de 2013.

Se há meios de alterar a visibilidade de alguns itens em diversas timelines, o mesmo pode ser feito para incrementar ou reduzir a visibilidade de conteúdos altamente específicos ou de pessoas relevantes para a ferramenta.

Uma vez mais, não é a questão imediata se a Facebook o fez, mas se pode fazer.

Ou seja, enquanto as informações de cada indivíduo são escrutinizadas, escamoteadas, extrapoladas e modeladas, as informações dos algoritmos estão protegidas fortemente pelas leis de propriedade intelectual e de patente.

Em palavras um pouco mais austeras, enquanto a matéria-prima, orgânica, social, está sendo processada, os meios de produção (algoritmos) seguem defendidos pelo capital, porém na pós ou hipermodernidade, sua presença por vezes mal é sentida.

Os meios de produção da cibercultura impelem o sujeito a entregar-se às claras, agem na penumbra e violentam no escuro. Poucos estão a ouvir, mais do que os cânticos, os lamentos.

Há caminhos de resistência ao enclausuramento através das estruturas de dados, mas isso certamente demandará um esforço considerável por parte de cada indivíduo. E se posta em prática, a busca por alternativas, nos dias atuais, seria uma ação contra os sistemas vigentes. A coerção social faria seu papel clássico e ofereceria barreiras econômicas e sociais a esta jornada.

\footnotetext{
${ }^{16}$ Sheherazade culpa Dilma e Zuckerberg por queda de audiência em sua página. Disponível em: $<$ http://www.pragmatismopolitico.com.br/2015/04/sheherazade-dilma-zuckerberg-por-queda-de-audiencia-emsua-pagina.html>. Acesso em 18 de abril de 2015.
} 
Em muitos casos, há a especulação de que o desafio da conquista do homem pelas tecnologias seja algo irreal. Abreu e Nicolau se apressam em indicar que "é preciso compreender que nem toda situação humana complexa pode ser reduzida a linhas em um gráfico, porcentagens ou números em uma tabela" (Abreu \& Nicolau, p. 6).

Há alguns meses a mera alusão à intransponibilidade dos sentimentos humanos a uma máquina causaria risos em muitos membros da comunidade científica, como se esta questão estivesse apenas no campo da ficção cinematográfica, mas quando uma de tecnologia não se acanha em anunciar publicamente que está aplicando cerca de 500 mil dólares australianos para ensinar um programa de inteligência artificial a sentir raiva, como é o caso exato do Touchpoint Group ${ }^{17}$, este ponto passa a ser mais um nó górdio a ser desatado pela sociedade contemporânea.

\begin{abstract}
Apesar dos equívocos aos quais ainda estamos sujeitos e das já consagradas técnicas de coleta de dados, é inegável que o big data representa mudanças significativas na forma como analisamos informações e, por sua vez, no modo como entendemos e organizamos a sociedade. (Abreu \& Nicolau, p. 6)
\end{abstract}

A mudança não se dá apenas através do âmbito mercadológico, mas também nele. A sociedade passa a se estruturar e responder ao assédio dos dados.

Os números, antes contadores da história, podem se tornar coprotagonistas, de certa forma, actantes indicando o passado-presente e o futuro-presente.

É aí que Bruno nos trará seu apontamento e alerta, que "com o uso de algoritmos e programas de composição de perfis ${ }^{18}$, os bancos de dados pretendem conter tanto o saber quanto o controle sobre o passado, o presente e o futuro dos indivíduos." (Bruno apud Fava, p. 6)

Isso por considerar que o passado, presentificado de modo constante, não está encerrado, muito menos apenas emana seus laços simbólicos, mas passa a ser presente da constatação e base da projeção. O futuro, que antes estava no devir, agora está registrado lastreado também nas fórmulas algorítmicas.

\footnotetext{
${ }^{17}$ Cientistas estão ensinando inteligência artificial a sentir raiva. Disponível em: $<$ http://br.ign.com/tech/3954/news/cientistas-estao-ensinando-inteligencia-artificial>. Acessado em 18 de junho de 2015.

${ }^{18}$ Termo conhecido como profiling, que indica a reunião de dados e utilização de técnicas de extrapolação de informação para construir uma visão sobre cada indivíduo, tornando-o identificável e acionável para fins diversos, como a publicidade.
} 
Em uma recordação da obra de Orwell, 1984, que já pôde ser lida de modo despretensioso, diriam alguns, se lerá que quem controla o passado controla o futuro; quem controla o presente controla o passado.

The Party said that Oceania had never been in alliance with Eurasia. He, Winston Smith, knew that Oceania had been in alliance with Eurasia as short a time as four years ago. But where did that knowledge exist? Only in his own consciousness, which in any case must soon be annihilated. And if all others accepted the lie which the Party imposed - if all records told the same tale-then the lie passed into history and became truth. 'Who controls the past,' ran the Party slogan, 'controls the future: who controls the present controls the past.' And yet the past, though of its nature alterable, never had been altered. Whatever was true now was true from everlasting to everlasting. It was quite simple. All that was needed was an unending series of victories over your own memory. 'Reality control', they called it: in Newspeak, 'doublethink'. (Orwell, p. 56 - 57)

Enquanto o partido controla o que foi, controla o que é. Controlando o agora, o futuro também lhe pertence. A aceleração, ao encerrar o resgate histórico passado, transformando seus contornos em presente instantâneo e fugaz, favorece a corrosão do presente e futuro refletidos, avaliados, mas os apresenta como um dado, como constatação. Como se disse anteriormente, será praticado o duplipensar na medida em que o indivíduo perceber, ou mesmo se apenas imaginar, a vigilância lhe coagindo.

Na medida em que a integração de múltiplas plataformas de dados em um metabanco de dados traz possibilidades amplamente proveitosas para a sociedade, a outra face da moeda também é verdadeira.

Os últimos anos têm assistido aflorar com maior corpo os debates sobre as cidades inteligentes ${ }^{19}$ que incorporam marcadores infotécnicos para reconstruir a experiência humana sobre o espaço público, alterando fluxos de carros, frequência de transporte público, tratamento de água específico para a demanda real, limpeza e coleta inteligente de resíduos.

Mas ao mesmo tempo as cidades inteligentes serão, na mesma medida, cidades monitoradas, hipervigiadas, tendo não mais centros técnicos de coleta de dados, mas uma estrutura integrada em rede para alimentar os sistemas de dados usando carros, postes, relógios, ruas, janelas. Cada objeto com acesso a uma fonte de energia pode ser um coletor e emissor de dados.

Soluções tecnológicas para o problema das super populações nas cidades, por exemplo, estão sendo criadas em vários lugares do mundo, tanto por pequenas empresas quanto por indivíduos, multinacionais e governos. O conceito de smart cities, ou cidades inteligentes, definidas como ambientes inteligentes, que embutem

\footnotetext{
${ }^{19}$ Derivado do termo recorrente em inglês, smart cities, que indica a utilização de estruturas infotécnicas de dados para auxiliar na gestão e configuração do espaço público e dos fluxos humanos.
} 
tecnologias da informação na comunicação, criando ambientes interativos, que trazem a comunicação para o mundo físico. (Abreu \& Nicolau, p. 8)

Assim, com os marcadores de dados, soluciona-se alguns entraves gerados pelas superpopulações, mas expõe o cidadão comum ao entrave, novamente, da indefinição contemporânea do que vem a ser a privacidade.

Neste sentido, a privacidade e a personalidade/identidade, no nível individual, e a constituição do social de acordo com a interação com comunicações e transformações provenientes de cálculos e decisões tomadas por inteligências artificiais estão em foco.

O que o marketing nos apresentou como ferramentas e serviços, com potenciais interativos e participativos, atualmente enxergamos como mecanismos de controle, monitoramento e vigilância, capaz de gerar um 'ficha' completa sobre cada um de nós, contendo todas as nossas ações e movimentos na internet, bem como fora dela (haja vista os serviços de geolocalização que habitualmente utilizamos em nossos celulares). (Santos e Nicolau, p. 6)

Os bancos de dados estão conectados em rede e com a internet. Comportamentos antes discretos ou mesmo imperceptíveis para a publicidade e para o governo agora estão integrados a estruturas de coleta de dados em tempo real que se liga a muitas condutas cotidianas, passando pelas mais óbvias como sites mais acessados ou mesmo comércio online e passando, inclusive, para estudos de comportamento de acordo com o tempo de leitura, modo de uso do cursor do mouse, tempo de resposta a estímulos específicos etc.

É sensível que a sociedade ainda esteja fascinada com o presente de Prometeu, e como Nero, pode acabar queimando as casas ou levando os corpos a serem infligidos da tortura prometeica diária vinda do mesmo Zeus que controla o raio e a eletricidade.

A pretexto de não fortalecer certa ilusão de vigilância acentuada apenas agora, as palavras dos autores acima fazem lembrar da vigilância inclusive através da geolocalização dos aparelhos celulares, mas ela está apenas facilitada nos dias atuais, já que as operadores de telefonia são capazes, e sempre foram, de dizer ponde cada cliente está durante cada segundo do dia através da triangulação de sinais, o mesmo sistema que até hoje ainda guia aviões ao redor do mundo.

Mas o importante é que o que pode estar em jogo é a capacidade de decidir, autonomamente, o caminho a ser seguido dentro de uma cidade, os espaços a serem experienciados.

Vale destacar que não está se contrastando a forma como hoje as pessoas transitam pela cidade e como elas o farão, como se houvesse apenas ganhos ou perdas, mas a 
automatização técnica do preenchimento dos espaços públicos precisará passar por um debate ético maior do que o que se instaura nos dias atuais.

[...] percebemos que o big data não apenas corrói a nossa autonomia, aumentando os riscos para a privacidade, mas altera as características desses riscos. Os usos secundários que surgem durante a coleta e o processamento das grandes quantidades de dados deslocam o foco para probabilidade: algoritmos, cada vez mais potentes, calcularão a probabilidade de pessoas comprarem um produto, terem um ataque cardíaco, não conseguirem pagar um empréstimo ou cometerem um crime, por exemplo. (Abreu \& Nicolau, p. 12)

Assim, o pré-crime, instituição constitutiva do direito na ficção hollywoodiana chamada "Minority Report" passa a ganhar contornos factíveis.

Populações inteiras passam a ser vigiadas remotamente e de modo constante e profundo, com métricas de comportamento social e agrupamento de perfil de interesse sem que sequer se dê conta que faz parte do público-alvo dos sistemas de controle da ordem pública.

Impérios são baseados em desejo de conquista, oportunidades históricas e inovação. Hoje, a conquista não é mais militar, é conceitual. Somos submetidos, um a um, aos processos dos novos tempos, que tem a individuação como principal conceito. $\mathrm{O} E \mathrm{Eu}$ passa a ser a principal expressão do mundo. Um mundo de solitários num mundo de massas conectadas. (London, p. 169)

Em que pese o fator desencadeante das acelerações em Trivinho, a relembrar, a guerra, a disputa, o campo a ser dominado na cibercultura passa a ser, então, o indivíduo.

É preciso pensar, não que se esteja a fazer uma apologia à frouxidão do Estado em prevenir os crimes e auxiliar na segurança social, mas em seu par vigilante, o controle é que deve estar em mente para compreender a cibernética, a vigilância e o esquecimento nas estruturas infotécnicas.

Esta percepção de frouxidão e a solicitação de maior segurança vai deslocar o poder democrático para o eixo vigilante. E não apenas a segurança, mas a comodidade.

Como exemplo do processo de aceleração das comunicações que está se aplicando, em busca da comodidade, o usuário já não se importa, se é que percebe, que ao encontrar um ícone do Facebook em todos os sites de notícias, ele está oferecendo seus dados a uma empresa que já está concentrando informações individualizadas e identificáveis. "O objetivo do Facebook Everywhere era simples: fazer com que toda a rede se tornasse 'social', levando a personalização no estilo Facebook a milhões de sites não personalizados." (Pariser, p. 40)

Se por um lado isso ocorre, favorecendo o usuário com a informação personalizada de modo ágil, prático, por outro lado aumentam as chances de invasão e evasão de privacidade. 
The main reason why censorship methods have not yet become more social is because much of our Internet browsing is still done anonymously. When we visit different sites, the people who administer them cannot easily tell who we are. There is absolutely no guarantee that this will still be the case five years from now; two powerful forces may destroy online anonymity. From the commercial end, we see stronger integration between social networks and different websites - you can now spot Facebook's "Like" button on many sites - so there are growing incentives to tell sites who you are. Many of us would eagerly trade our privacy for a discount coupon to be used at the Apple store. From the government end, growing concerns over child pornography, copyright violations, cybercrime, and cyberwarfare also make it more likely that there will be more ways in which we will need to prove our identity online. (Morozov, p. $100-101$ )

A cada nova etapa do desenvolvimento galopante das tecnologias de mensuração dos ambientes digitais, a comunicação e os elos desta cadeia se tornam mais expostos. Se é pelo rótulo da praticidade ou da segurança, o que se encontra é a aceleração das trocas simbólicas sendo exprimida por diversos autores, e a vigilância pantópica passa a ser, em alguns momentos, aceita, como no caso das ofertas de desconto ou serviços personalizados, e em outros desejada, como no caso da segurança.

Quanto ao quesito de vigilância, encontra-se em Foucault:

[...] que nenhum crime cometido escape ao olhar dos que têm que fazer justiça; nada torna mais frágil o instrumento das leis que a esperança de impunidade; como se poderia estabelecer nos espírito dos jurisdicionados um laço estreito entre um delito e uma pena, se viesse afetá-lo um certo coeficiente de improbabilidade? Não seria preciso tornar a pena tanto mais temível por sua violência quanto ela deixa menos a temer por sua pouca certeza? Mais que imitar assim o antigo sistema e ser "mais severo, é preciso ser mais vigilante" (Mably). Daí a ideia de que o instrumento de justiça seja acompanhado por um órgão de vigilância que lhe seja diretamente ordenado, e permita impedir os crimes, ou, se não cometidos, prender seus autores [...]. (Foucault, p. 92)

Mas na contracorrente, ao mesmo tempo que se espera segurança, espera-se ser ente capaz de usufruí-la, o que geralmente pode pressupor fazê-lo livremente. Então, em sociedades da vigilância pantópica, que povo pode florescer livremente sem os passos vacilantes que fazem parte da constituição da pessoa humana? Quais são as condutas que poderão ser consideradas realmente suspeitas? Em que medida o indivíduo, ao se perceber vigiado, será capaz de romper a barreira da autovigilância e da vigilância presumida? A quais valores o indivíduo prestará condolências? Aos seus ou àqueles que imagina serem do vigilante pantópico?

[...] sou um indivíduo que age, mas também uma planta; que muito do que não fiz contribui para fazer com que eu seja tudo aquilo pelo qual eu deva ser louvado ou culpado; que devo constantemente escolher entre bens concorrentes e aparentemente incomensuráveis e que as circunstâncias podem forçar-me a uma posição na qual não posso evitar ser falso com respeito a alguma coisa ou fazer algum mal; que um evento que simplesmente acontece a mim pode, sem meu consentimento, alterar minha vida; que é igualmente problemático confiar seu bem a amigos, amantes ou ao país e tentar ter uma boa vida sem eles - tudo isso considero não apenas como o 
material da tragédia, mas como fatos cotidianos da razão prática vivida. (Nussbaum, p. 5)

Quando acessar um site para comprar panela de pressão para cozinhar um feijão passa a ser motivo de alerta para um governo, afasta-se o Estado provedor e se aproxima o Estado determinador.

A quem está dada a consciência infotécnica para avaliar o acaso ou a conjuntura antes do julgamento público dos algoritmos? Se por um lado isso devolveria aspectos humanos à curadoria contemporânea, por outro poderá ser rotulado de censura prévia. Esta berlinda seguirá assistindo a batalha, aparentemente, por muito tempo, sem que o pendão pare em um dos lados. Ainda assim, em um questionamento mais polêmico, qual seria a diferença entre uma ditadura e uma democracia ao final da próxima década com tantas estruturas de vigilância e condicionamento infotécnicos?

Muitas serão as diferenças, mas não necessariamente para o mal, tanto quanto sequer para o bem da coletividade.

Pariser vai indicar o que chama de colapso de atenção como um ponto relevante dos desdobramentos midiáticos do excesso de informação e comunicação na contemporaneidade. Para o autor, "vamos depender cada vez mais de curadores humanos e robóticos que determinarão as notícias que consumimos. Os editores humanos profissionais são caros, o código é [são] barato[s]." (Pariser, p. 50, grifos nossos)

Quando qualquer cidadão pode estar sob ferrenha vigilância e aquilo que ele é para o Estado é o que dele se coleta de dados a todo instante e o produto dos cálculos algorítmicos, viver sob a democracia técnica da invasão da privacidade poderá se converter em uma castração maior do que alguns dos campos de concentração de guerra sob o prisma da identidade e da dignidade humana.

Expressão forte, mas que pode ser justificada.

Enquanto o preso político é muitas vezes humilhado e maltratado, ele conhece a realidade fora daquelas grades e pode contar com um retorno à liberdade, sabendo que seu estado é o de exceção.

Já o sujeito "livre" da sociedade hipervigiada não está em condições de fugir à regra, sendo rastreável e encontrável a cada segundo. Seu estado é o da regra. A exceção poderá ser instantaneamente encontrada e suprimida no futuro, e a exceção atual pode ser motivo de punição no futuro, para o qual não há garantias. 
Ainda que o prisioneiro de guerra tenha suas roupas destruídas e seu cabelo raspado em busca do aniquilamento de seus lastros identitários, ele preserva a memória do que é.

O sujeito enclausurado na bolha semântica dos algoritmos pode se lembrar e tornar um sujeito auto-engendrado em gostos perpétuos, sem a visão do que poderia vir a ser ou sequer daquilo que um dia foi.

Mas não se deve pensar que por si só isso leve o indivíduo a uma infelicidade. Pode ser que o resultado seja exatamente o oposto, dentro do campo imaginal. Mas enquanto o imaginal não aflorar com força, a pressão pode ser suficientemente forte para manter os indivíduos em estado de conforto e ignorância.

[...] na era da dromocracia cibercultural, costuma vencer, em geral, o sujeito com tal perfil, quem cuja subjetividade e cujo corpo já não questionam se devem ou não deixar-se embalar pelo frenesi digital. Triunfa - ou, ao menos, tem possibilidades maiores disso - quem segue (vale dizer, a violência, sem vê-la), expressão limite de um conservadorismo absoluto, absurdamente assimilado à imagem da própria felicidade. (Trivinho, p. 106-107)

Mais aceito, mais bem sucedido, mais apto, mais dromoapto é o sujeito que aceita, que não questiona e que, por conta disso, vai sentir de forma ainda mais atenuada os efeitos da dromocracia, e terá as chances de encontrar a felicidade ignorante de suas condições restritas.

Este filtro sedutor, que anestesia o sujeito contemporâneo, acaba sendo o filtro do conforto, da manutenção, do menor atrito, da felicidade instantânea e fugaz que precisa ser diuturnamente perseguida.

Neste caminho estará Baudrillard indicando que

Do mesmo modo que a liberdade se impõe como a solução mais fácil para o problema do sujeito e de seu destino, assim a felicidade impôs-se como a solução mais fácil para o problema do mal. Ou, de preferência, a infelicidade, por ser mais fácil de administrar do que a felicidade, é a solução para o problema do mal. Do mesmo modo que a liberdade acaba na libertação integral e, em ab-reação a esta, em uma nova servidão, assim o ideal inaceitável da felicidade integral culmina em uma verdadeira cultura da infelicidade, da vitimização, da recriminação, do arrependimento, da denúncia e da compaixão miserabilista. (Baudrillard, p. 138)

Liberdade cativadora, felicidade angustiante.

Pentzold e Sommer trarão um ponto importante sobre memória, e, claro, sobre esquecimento, ao estudar o caso do perfil de Henio Żytomirski no Facebook.

Since 18 August 2009 the social networking site Facebook has a new member: Henio Żytomirski, born 1933 in Lublin, Poland. At first sight, that's nothing special. But the fact that Henio was murdered in the extermination camp Majdanek at the age of 8 makes him different to the other Facebook users. His newly acquired Facebook friends can "meet" his virtual profile, they can watch his digital photos showing him with his family or they can send him messages. And occasionally, 
Henio even posts about his experiences as if he would still be with us today. (Pentzold, p. 72 - 73)

É importante destacar o que foi indicado antes da citação. Pentzold e Sommer estudaram o caso "do perfil de Henio Żytomirski, não do próprio Henio Żytomirski apenas. A relevância está tanto no fato do polonês ter sido morto aos 8 anos de idade quanto por ter um perfil criado no Facebook não para contar sua história, mas para manter no presente "sua" narrativa.

Este caso emblemático traz para o presente um passado que não poderia se atualizar com base no próprio indivíduo, mas que toma sua história como suporte e presentifica a sua narrativa.

A memória, neste caso, está lutando contra o esquecimento de um modo diferente. Busca manter vivo o discurso e seus símbolos através de um vínculo identitário do avatar com o pequeno Żytomirski.

Quando, a exemplo, Nussbaum analisa as tragédias de Ésquilo, traz também uma referência de que "Se se fizer uma clara distinção lógica, evidentemente, há de se dizer: 'um homem que age sob necessidade não está agindo voluntariamente"' (Lesky apud Nussbaum, p. 22).

Este item é importante na medida em que o indivíduo, cercado pela tecnologia, e compelido a agir rapidamente pela cibercultura pode tanto ser considerado, de um ponto de vista, como mais capaz de participar da vida pública e de atuar de modo mais profundo da sociedade através do acesso à informação e dos meios de comunicação, mas por outro como um sujeito cerceado das condições de autonomia plena em suas escolhas.

Isso é pensar sobre nó górdio da ação sob o jugo a necessidade.

Mas neste estudo atual, tal ação sob necessidade poderá ser considerada como sendo o resultado da cibercultura na visão de Trivinho (2007) conquanto a ação imperativa esteja sob as demandas da dromoaptidão, do comunicar-se sem tempo, do imediatismo.

Conquanto este imperativo possa estar a dar os contornos das dinâmicas sociais e da definição de quem é cidadão na polis tecnicizada, esta necessidade por menos biológica que possa ser, ainda é uma necessidade a ser atendida para garantir a constituição do indivíduo como sujeito, como comunicante, como cibercidadão temporariamente aceito, mas eternamente testado e questionado, demandado. 
A prevenção de comportamentos perigosos ou ilegais é uma das bases da sociedade moderna. Medidas preventivas diminuem a liberdade das pessoas. Entretanto, muitos as veem como um preço pequeno quando comparadas ao mal evitado. $\mathrm{O}$ que não pode passar despercebido é que, em tempos de big data, esse caminho pode terminar em uma encruzilhada. Apesar de os sistemas ainda serem embrionários, a promessa é aperfeiçoar os mecanismos. Algoritmos farão previsões baseadas em análises de dados tão precisas que as pessoas não se tornarão culpadas pelo que fizeram, mas pelo que pretendiam fazer. (Abreu \& Nicolau, p. 12)

Assim, o exercício clássico oferecido aos alunos de direito no início do curso, que sempre foi avaliar se um grupo perdido em meio a um local ermo por semanas a fio, sendo levado ao assassínio de alguns para garantir, pelo canibalismo, a vida de outros, pode ganhar um par à altura.

O réu de assassinato no ano de 2030 poderá ser condenado por crime doloso, mas não culposo, por pretender matar alguém segundo um relatório psicotécnico com base em dados comportamentais? Enquanto hoje a base do crime é a culpa, mas o agravante é o dolo, ou seja, a intenção, num futuro onde as previsões serão capazes de apontar o assassínio antes do ato, a culpa não caberá sem a materialidade do ato, mas o dolo poderá ser a base para a reclusão e tentativa de tratamento / ressocialização?

Assim, os autores Abreu \& Nicolau são categóricos em dizer que "a era do big data exigirá novas regras para salvaguardar a liberdade e a privacidade das pessoas." (Abreu \& Nicolau, p. 13) Há de se dar um passo além e indicar que nesta era, que ainda não se cristalizou, que ainda se transforma, será preciso, ou melhor dizendo, é preciso atuar em busca de novas regras para salvaguardar a liberdade, a privacidade e, acima de tudo, o direito à identidade das pessoas.

Embora a hipervigilância tenha nos levado a este ponto extremo de personalização, manipulação de comportamentos e limitação de repertório, é preciso deixar claro que quando se fala em rede digital é impossível não pensar em alguma tecnologia que não passe pela seleção e filtragem de informações ao usuário [...].(Fava, p. 12)

As palavras da autora são relevantes para destacar que embora a análise feita ao longo de toda esta obra evidencie alguns imbricamentos e pontos nebulosos a cerca do esquecimento e das estruturas de dados / estruturas de memória, não está em foco fazer um juízo de valor sobre as empresas que oferecem estes serviços, em si, ante uma necessidade clara de suporte na avaliação de conteúdos que possam ser relevantes para cada sujeito. Mas por relevante, vale destacar, não se devem considerar aqueles que corroboram com um conceito preconcebido do receptor ou que vá alegrá-lo, mas sim aquele conteúdo / diálogo que favorecerá a evolução do sujeito e da sociedade para um bem sócio-antropológico elevado. 
Enquanto muitos se preocupam em enxovalhar a imagem de grandes ícones do mercado digital como a Google e a Facebook, é relevante trazer ao foco o efeito pirotécnico que está ofuscando a visão de muitos sobre o tema. Se o debate tivesse que recair (apenas) sobre o mercado, ainda assim seria necessário ampliar tal escopo. "Por trás das páginas que visitamos, está crescendo um enorme mercado de informações sobre o que fazemos na rede, movido por empresas de dados pessoais pouco conhecidas, mas altamente lucrativas, como a BlueKai e a Acxion." (Pariser, p. 12)

Entretanto, frise-se, a distância entre o ético e o lícito não é o objeto desta obra, mas o fato é que a princípio as operações das duas empresas seguem majoritariamente as leis dos países onde operam, ocorrendo ações judiciais para julgamento de direitos e violações, mas fato é que estes são os rostos de uma nova cultura que ainda não foi plenamente compreendida e sequer abarcada claramente pela legislação de muitos países.

Assim, não é a Google ou a Facebook que estão em pauta, mas a pressão de mercado que suplantará até mesmo estas empresas caso lutem contra esta força sem ter o respaldo legal e jurídico de forma consolidada em grande parte dos países.

Destaque-se, então, que

Os empresários que exploram os processos tecnológicos, os cientistas que lhes fornecem os meios e os técnicos (engenheiros, designers etc.) que os operacionalizam são apenas uma face desse cenário. Os indivíduos comuns que os consomem os empregam e os adaptam a seu modo de vida e às suas necessidades de forma mais ou menos significativa são o outro lado da moeda, para não falar de todos os que ajudam a elaborar a sua imagem para a sociedade. As tecnologias de informação não são função de um propósito social pré-determinado: são parte do contexto histórico em meio ao qual a vida é articulada. As pessoas possuem o poder de reinventar em sentido simbólico o caráter funcional dos aparatos tecnológicos. (Rüdiger, p. 66)

Ou seja, a responsabilidade e a potencialidade não está apenas do lado das corporações, no entendimento que Rüdiger traz sobre o pensamento de Feenberg, mas também estão intrinsecamente ligadas à conduta humana e suas escolhas.

Assim, enquanto os fogos de artifício que objetivam esvaziar o debate colocam estas duas empresas, principalmente, no foco, outra gama ainda maior de corporações segue silenciosa e incólume com suas ações de mineração, cruzamento e lavagem de dados sem sequer chegarem ao conhecimento do usuário final da internet, seja ele visto como consumidor ou cidadão. 
Manter o foco em duas empresas é, em primeiro lugar, atacar apenas uma parcela pequena do ecossistema de dados, e em segunda instância, ignorar que o sujeito, seja ludibriado, seduzido ou mesmo por escolha própria, é também o sustentáculo desta estrutura.

Um ponto pertinente, então, é compreender que mesmo que a Google decida parar de usar dados para oferecer conteúdos especializados para cada tipo de pessoa, outra empresa surgirá em pouco tempo com maestria suficiente para enredar tantos outros no mesmo consumo de informação. O mesmo serve para a Facebook e sua rede social homônima, que mais do que tantos outros exemplos, é o destaque da obsolescência do Orkut. E isso ocorrerá justamente pelo conforto e satisfação que os indivíduos exigem, já acostumados com as facilidades dos sistemas infotécnicos, pouco desejosos de se despirem deles.

Diria Boétie, o que se pode tomar em paralelo como cabível a respeito do costume contemporâneo tanto em relação às facilidades quanto com os riscos e problemas atrelados.

[...] o hábito, que exerce em todas as coisas um poder irresistível sobre nós, não tem em lugar nenhum força tão grande quanto a de nos ensinar a servir. E como dizem de Mitrídates, que foi se acostumando aos poucos ao veneno, aprendemos a engolir sem achar amargo o veneno da servidão. (La Boétie, p. 45)

Em outras palavras, estas empresas costumam ser alvos preferidos, mas fato é que os dados digitais estão sendo disseminados de modo desenfreado por uma questão técnica atrelada à facilidade de captura, cópia e replicação de dados digitais e pelo vácuo legal que se instaurou nas últimas décadas sobre este novo campo de atuação social, entre outros temas.

O internauta médio e contemporâneo já se habituou a compartilhar seus dados. Reluta em alguns casos, mas pouco nega em outros.

Enquanto isso,

"[...] accessible digital memory may enhance short-term efficiency but expose individuals or society to potentially harmful consequences. [...] Perfect remembering exposes us to filtering, selection, and interpretation challenges that forgetting has mostly shielded us from." (Mayer-Schönberger, p. 96)

É mister destacar, através das palavras de Santos e Nicolau, que "nenhuma empresa deixa claro o direcionamento real dos dados colhidos, e mesmo aquelas que tentam esclarecer, não disponibilizam nenhuma garantia de agir de acordo com o que é dito." (Santos \& Nicolau, p. 2)

Isso significa que ainda não está claro para o internauta médio como os seus dados são tratados por cada empresa, quais são as barreiras de segurança, e, principalmente, o que jamais será feito a partir desta coleta de dados, como entregar os dados a empresas parceiras. 
Este é o tipo de tema que acaba por abrir uma nova janela de debate na medida em que enquanto algumas empresas declaram publicamente que estão coletando dados e se dedicam em protegê-lo, outras mal informam a coleta.

Há ainda aquelas que além de coletar, compartilham a informação de modo a dificultar qualquer controle por parte do usuário sobre quem detém qualquer tipo de informação a seu respeito, e qual informação é essa.

A propagação de dados hoje está em toda parte e envereda por caminhos cada vez mais obscuros e sutis. Mesmo que exista a necessidade de filtros no ciberespaço, quanto mais eles extrapolarem suas previsões, mais o usuário se tornará seu refém. (Fava, p. 12)

O debate pode ter seu foco em qual empresa ou governo está executando ações com base nos dados privados das pessoas ou pode se concentrar nos aspectos sociotécnicos, nas possibilidades e nas formas de conduzir este processo a resultados eticamente desejados.

Ater o debate às marcas é aceitar a pirotecnia que desvia o olhar das formas de recolocar a humanidade na dianteira da tomada de decisão sobre os caminhos que trilhará.

\subsection{CONFLITO ENTRE SUJEITO E DADOS}

Se hoje muito se debate sobre o nível de profundidade que as estruturas de dados atingem para entregar ao internauta um tipo de conteúdo segmentado, mas é urgente compreender também que as tecnologias utilizadas atualmente são ultrapassadas. Isso ocorre pois uma tecnologia só ganha escala de uso na medida em que se torna mais compreensível e comum para seus usuários.

Em outras palavras, é preciso tempo. O mesmo tempo que ajuda a desenvolver as pessoas para o uso de cada tecnologia é o tempo que lhe rouba o caráter inovador. Isso ocorre pois, por mais ágil que seja o aprendizado de uma tecnologia, o planejamento de inovação das empresas de dados segue ganhando terreno minuto a minuto, avançando muito além do que se pratica massivamente nas empresas.

Neste contexto, entender o ecossistema tecnológico atual é compreender os impactos da tecnologia que foi desenvolvida anos atrás. Começamos, então, a entender brevemente como a tecnologia dos anos anteriores estão sendo utilizadas. Veremos algumas de suas características e em seguida buscaremos compreender como a infraestrutura atual traz condições de transformar o sujeito em sua relação com a tecnologia. 
É comum encontrar debates acadêmicos a cerca da publicidade e seus efeitos na formação da criança e do adolescente, mas muitas destas avaliações estão concentradas na publicidade impressa ou televisiva. Mais recentemente, muito se dedicam a estudar o impacto da internet no desenvolvimento da subjetividade e das habilidades da nova geração.

Um ponto importante, para seguir com o estudo proposto é compreender que juventude é esta que acessa a internet e interage com as novas tecnologias. Ainda que muito se conte sobre este sujeito, podemos identificar as características apontadas por Tapscott (2009) como fator relevante.

Entre elas estão a liberdade, customização, escrutínio, integridade, colaboração, entretenimento, velocidade e inovação (Tapscott, p. 74). O ponto certeiro para melhor se concentrar na questão proposta é a correlação entre a velocidade, entretenimento e controle praticado por jovens, por exemplo. Para isso, é necessário ir mais fundo e pensar como é possível obter informações e até mesmo entretenimento na web hoje em dia de modo tão rápido, mas, ao mesmo tempo, como encontrar uma maneira de ser assegurar que o que foi obtido é "real" e de fontes "confiáveis".

Quando estas questões são exploradas é mais fácil de entender parte da complexidade. A juventude não é o único grupo que se encontra na rede e essas características estão superando barreiras culturais e econômicas, de certa forma.

É importante destacar que ainda que a internet possa impactar profundamente a fida de seus usuários, quando questões como inclusão social ou esquecimento na rede, torna-se mais difícil avaliar o quão incluídos e capazes de avaliar esta inclusão estão os usuários atuais da rede.

Isso significa que não basta oferecer infraestrutura de hardware ou programas tecnológicos sem que os usuários da rede tenham o entendimento de suas funcionalidades, linguagens, oportunidades e riscos. Não basta considerá-los aptos a lidarem com este ecossistema apenas por conhecerem alguns comandos simples, principalmente em tempos de redes sociais que resumem a interação majoritária a clicar em um botão de curtida.

É preciso, então, que o grande volume de usuários da rede, de algum modo, possam compreender mais aprofundadamente a estrutura tecnológica e cognitiva para se tornar mais autônomo em sua escolha e conduta na rede. Na mesma medida vale destacar que este empoderamento precisa ocorrer não apenas na internet do "www", em si, mas de um modo 
mais amplo e menos míope, já que o entorno social está cada dia mais permeado pela tecnologia e por estruturas de dados, colaboração, serviços e, por vezes, vigilância.

Em palavras melhores, as tecnologias acabam por influenciar a dinâmica entre as pessoas e suas condições contemporâneas de comunicação e conduta através das redes, entre redes e entre pessoas.

Sendo breve e ao mesmo tempo contextualizando as próximas linhas, o uso de sites de redes sociais tem aumentado a cada dia. Um relatório publicado pelo PewResearch Internet Project $^{20}$ indica que no final de janeiro de 2014 ao menos $74 \%$ dos adultos online já tinham ao menos uma conta criada neste tipo de site. Isso significa que praticamente 3 a cada 4 habitante da rede com idade superior a 18 anos usa este tipo de tecnologia para se conectar e conversar com outras pessoas.

Um bom ponto de vista sobre estes dados é que os sites de relacionamentos sociais acabam por estimular a manutenção ou reconstrução de laços sociais antigos, por exemplo. Mas por outro lado, é possível perceber dois fatores importantes. O primeiro, que quanto recorrente é o uso de uma rede por um indivíduo, maiores as chances de que este indivíduo acabe aplicando esforços para convencer seus amigos a participarem das mesmas redes. A mesma questão poderá ser vista em Mayer-Schönberger, acrescentando a questão do esquecimento e da memória dentro do mesmo bojo.

$[\ldots]$ every new user joining to share information increases the value for all existing users. Still, one could argue, even though users see the internet as a global tool for information sharing among individuals, users choose deliberately to permit others to access information through the global network. If they do not or no longer want to grant others access, they can do so. After all, the beauty of digitized information is that erasing it is as easy as clicking 'delete'. This may sound true at first, but it rarely is for at least two reasons, both of which are fundamental to how information networks operate. The first that once one has shared information, one has essentially lost control over it. [...] The second reason why we may no longer be the masters of out information treasures is that each online interaction itself - even if one does not share files - is information about oneself that one's interaction partner(s) now have, and can possibly share with others. (Mayer-Schönberger, p. 85 - 87)

Através deste debate, publicar um dado é dar este valor ao grupo, mas perder o controle sobre quem acessa esta informação. Neste mesmo sentido, quanto mais informação compartilhada entre seus membros, mais valiosa tenderia a ser uma rede, e mais difícil será prescindir dela, migrando de rede, de tecnologia. Mas o imperativo da dromoaptidão cobrará este custo para seguir o processo de exclusão daqueles que não forem capazes de acompanhar os movimentos sociotécnicos.

\footnotetext{
${ }^{20}$ Social Networking Fact Sheet. Disponível em: <http://www.pewinternet.org/fact-sheets/social-networkingfact-sheet/>. Acessado em 15 de fevereiro de 2015.
} 
O segundo ponto, então, com base em Pariser (2012), se mostra na dificuldade e alto custo para se desvencilhar da rede quando seu "capital social" está consolidado ou altamente ligado à rede em questão, consonante com o exposto acima.

\begin{abstract}
A dinâmica do aprisionamento é descrita pela lei de Metcalfe, um princípio cunhado por Bob Metcalfe, inventor do protocolo Ethernet que conecta computadores. A lei diz que a utilidade de uma rede aumenta cada vez mais rápido sempre que acrescentamos uma nova pessoa à rede. [...] Quanto mais aprisionados estiverem os usuários, mais fácil será convencê-los a se conectar às suas contas. (Pariser, p. 42)
\end{abstract}

Os responsáveis pela pesquisa referenciada há pouco resumem parte dos impactos das redes sociais ao indicar que elas estariam sendo cada vez mais usadas para manter laços sociais mais fortes e próximos, porém o outro fato é que essas pessoas acabam por oferecer um grande volume de informações para uma variedade considerável de empresas que estão em uma corrida para descobrir qual é a melhor maneira de converter cada pessoa em um consumidor, conduzindo ou incentivando os usuários da internet a revelarem informações pessoais que serão utilizadas posteriormente de diversos modos, entre eles, a publicidade online, que não é a única a se beneficiar, vale destacar novamente, deste tipo de prática.

Ainda assim, o interesse comercial está altamente incluído no pano de fundo das redes sociais e acaba por influenciar suas estruturas de conteúdo. Isso significa que o conteúdo segmentado leva em conta o potencial de cada publicação ou comentário de gerar o que é chamado de "engajamento social", que nada mais é do que as interações geralmente limitadas de um usuário com o conteúdo publicado por alguém em sua rede de contatos. Ou seja, ao invés de "engajamento social" significar algum tipo de conduta, ação, capacitação ou empoderamento de seus usuários, hoje esta expressão tem se resumido em um clique.

Com um simples clique ou qualquer comentário leviano, um usuário pode ser considerado engajado com um tema específico, o que não necessariamente significa qualquer mudança significativa em sua conduta social. Da mesma forma, assim como uma pessoa não está realmente engajada apenas por ter clicado em uma imagem, as empresas e sites de redes sociais não são obrigados a se aplicarem profundamente nos aspectos éticos que garantam que seus algoritmos de curadoria de conteúdo.

Isso significa que estas empresas, hoje, estão autorizadas a privilegiar qualquer fator que lhe seja comercialmente relevante como item predominante e de maior peso nas atribuições de valor e visibilidade de conteúdo em seus ambientes. Em outras palavras, ocasionalmente uma pessoa pode receber conteúdos de um amigo próximo em sua linha de 
mensagens (newsfeed) à medida que interaja com as publicações de seu contato, mas também pode ocorrer de não haver visibilidade suficiente para assuntos relevantes se o espaço estiver tomado por anunciantes com interesse neste mesmo público.

O que afirmei acerca do jornal e do cinema se aplica igualmente ao rádio, à televisão e mesmo à venda de livros. Vivemos, pois, numa época em que ao enorme volume per capita de comunicação corresponde um fluxo cada vez menor de volume total de comunicação. Mais e mais, vemo-nos obrigados a aceitar um produto padronizado, inofensivo e insignificante, que, como o pão branco das padarias, é fabricado antes devido às suas propriedades de conservação e venda que ao seu valor alimentício. (Wiener, p. 130)

Wiener está destacando que, antes de se questionar o que é melhor para cada pessoa, o critério da produção, e aqui se inclui a produção de notícias, dados e comunicação, estará centrado potencialmente em sua possibilidade de padronização econômica antes de seus impactos.

Ou seja, é preciso debater não apenas o que cada pessoa executa nas redes informatizadas, mas também qual é o nível de liberdade que cada pessoa tem de escolher diretamente o conteúdo que gostaria de acessar, e também, quais assuntos não são muito digestos para o público médio mas que são de extrema relevância para a saúde da sociedade democrática. A liberdade está posta como fato concreto e cotidiano, mas sua incongruência contemporânea está sutilmente ocultada pelo véu da dromocracia cibercultural na medida em que é difícil debater o empoderamento e a inclusão das pessoas em qualquer sistema quando elas estão condicionadas e estimuladas coletivamente a seguir apenas os caminhos prédeterminados e sem a liberdade para testar e ir mais à fundo nos temas de interesse.

Liberdade, como qualquer outro termo, está construído historicamente, e seu significado se apresenta plasticamente nas relações humanas, modificando-se a cada momento, transformando seus contornos de acordo com o contexto, com os sujeitos envolvidos, com o entorno que se apresenta a estes agentes que se utilizam da linguagem. Em outras palavras, por mais que pareça, de certo modo, cristalino o conceito de liberdade, é necessário um breve olhar para compreender que, mesmo na efervescência do discurso libertário muito presente no ocidente, há cerceamento do sujeito em qualquer sociedade. Por mais que se intencione a liberdade do sujeito, este está fadado a seguir sob o crivo da linguagem, das relações interpessoais que pedem ajustamentos, da dinâmica de poder, entre tantos outros.

Além dos macrofatores, encontramos os traços finos desta relação claudicante do significado de liberdade a cada cultura, a cada grupo. 
Conquanto muitos reclamem da falta de liberdade da mulher que sai à rua de burca, muitos questionam que tipo de liberdade há na América, se não uma liberdade atrelada ao capital e ao mercado, referenciando nossa liberdade como algo que se aproxima muito mais de um liberalismo econômico e consumista do que uma real liberdade em diversos âmbitos.

Mas quando olhamos pela ótica do direito, entendemos que os cerceamentos impostos ao indivíduo são por vezes arquitetados em benefício do coletivo, do público, e neste caso específico, a promotoria pública ainda lembra que age tanto na defesa dos direitos de cada cidadão contemporâneo quanto o direito das gerações futuras. Ou seja, mesmo aquele que ainda não existe em nossa sociedade pode fazer parte, hoje, dos motivos e das forças de restrição de conduta. Esta avaliação inicial se faz necessário para que o termo "liberdade" não seja tomado, neste trabalho, por algo simplista.

A liberdade que se procura identificar é a liberdade de ser, de se ser, de se construir sem o conhecimento e a âncora do que se foi, de manifestar suas características e desenvolvê-las de acordo com o desenvolvimento do próprio sujeito e as interferências e influências do entorno. Porém, dirá Adorno, que “o consumidor não é soberano como a indústria cultural gostaria de fazer crer, não é o seu sujeito, mas o seu objeto.” (Adorno apud Wolf, p. 77)

Levando em conta que, nos dias atuais, o consumidor das redes sociais é o produtor de conteúdo, e que seu consumo é, de certo modo, controlado, este indivíduo passa a ser uma das exemplificações menos controversas da transformação do consumidor em produto.

\title{
3.2 IDENTIDADE E SEU DISCURSO
}

\begin{abstract}
Contem que Licurgo, legislador de Esparta, havia criado dois cães nascidos da mesma mãe e amamentados com o mesmo leite. Um foi engordado na cozinha, o outro acostumado a correr pelos campos seguindo o som da trompa e da corneta. Querendo mostrar ao povo da Lacedemônia que os homens vivem como a educação os fez, expôs os dois cães em praça pública e colocou entre eles um prato de sopa e uma lebre. Um correu para o prato, o outro para a lebre. (La Boétie, p. 46)
\end{abstract}

A questão das liberdades e das estruturas de memória e vigilância se complexifica um tanto mais quando, através do presenteísmo da internet, os contextos, os entornos não se desfalecem com a distância, e o locci dos sujeito lida com a vigilância tecnológica não de um, não de uma máquina, mas de toda a rede, que integra múltiplos agentes. 
Palácios, por exemplo, se dedicará em demonstrar ou ao menos sugerir que "nunca em tempos históricos nossa sociedade esteve tão envolvida e ocupada em processos de produção de memória; nunca o estoque de memória social esteve tão fácil e rapidamente disponível [...]" (Palácios, p. 38 - 39)

E a memória, fator crucial para a constituição discursiva dos indivíduos, está no epicentro das transformações contemporâneas, assim como sua batalha contra o esquecimento.

Desta forma, é mister entender se ainda pode o sujeito construir, livremente, sua identidade, sua manifestação do eu, de acordo com suas necessidades, objetivos, interesses, contingências, se os contornos dos grupos está penetrado e minado pelo toque escrutinador das redes. "The future has a chilling effect on what we do in the present. Through digital memory, the panopticon surveys us not just in every corner but also across time." (MayerSchönberger, p. 12)

Então, para entender este sujeito manifestando que ele é, e assim, por quais caminhos seu sujeito trafega, livre ou não, com direito a qual nível de privacidade, memória, rememoração e esquecimento, recorre-se a diversos pensadores.

Uma forma relevante de pensar a identidade, e com isso, o indivíduo, é que esta se apresenta como um discurso representativo, algo que apresenta uma realidade imaginada, uma realidade construída.

A princípio, antes de imaginar que seja a identidade algo pronto, algo sólido, por isso mesmo, Bauman é requisitado, em sua obra "Identidades" dada a construção constante e dinâmica do que vem a ser considerada a identidade nos dias de hoje. De pronto podemos perceber que o termo é declarado pelo autor em sua forma plural, e ao longo de suas páginas é possível ver o posicionamento do autor sobre como esta constituição se dá nos dias atuais, sem um centro específico, fugidia.

[...] a "identidade" é uma ideia inescapavelmente ambígua, uma faca de dois gumes. Pode ser um grito de guerra de indivíduos ou das comunidades que desejam ser por estes imaginadas. Num momento o gume da identidade é utilizado contra as "pressões coletivas" por indivíduos que se ressentem da conformidade e se apegam a suas próprias crenças (que "o grupo" execraria como preconceitos) e a sues próprios modos de vida (que "o grupo" condenaria como exemplos de "desvio" ou "estupidez", mas, em todo caso de anormalidade, necessitando ser curados ou punidos). Em outro momento é o grupo que volta o gume contra um grupo maior, acusando-o de querer devorá-lo ou destruí-lo, de ter a intenção viciosa e ignóbil de apagar a diferença de um grupo menor, forçá-lo ou induzi-lo a se render ao seu próprio "ego coletivo", perder prestígio, dissolver-se... Em ambos os casos, porém, a "identidade" parece um grito de guerra usado numa luta defensiva: um indivíduo 
contra o ataque de um grupo, um grupo menor e mais fraco (e por isso ameaçado) contra uma totalidade maior e dotada de mais recursos (e por isso ameaçadora). (8283 Bauman)

De pronto já é possível, pelas palavras expostas, entender que a identidade está posta como discurso entre pessoas, entre disputas, mas não apenas aí.

A reflexão sobre a identidade levanta o problema mais geral da integração das pessoas num espaço coletivo (o reconhecimento de uma pertença) e, simultaneamente, o problema ligado ao fato de que essas pessoas buscam um lugar específico neste mesmo espaço coletivo (elas buscam diferenciar-se, singularizar-se). (Deschamps, p. 17)

Com o problema da integração das pessoas no espaço coletivo, no desejo e necessidade de pertença, e na mesma medida sua necessidade de distinção, a identidade está em sua origem e atualização apresentada como campo de disputas sobre quem este sujeito pretende apresentar como figura representativa de si próprio.

Conquanto o fato duro da existência deste sujeito, o que busca é um substituto representativo, um signo complexo que oferecerá e oportunizarão significações a este sujeito intencionado, desejante e significante.

De certa forma, então, há já os traços da necessidade de construção da identidade, não como uma realidade colada, atrelada ao sujeito por qualquer marca de nascença, mas por sua atuação e, dentro do conflito visto acima, pela atuação dos outros agentes sociais, conquanto esta identidade seja fruto de uma negociação constante. Na medida em que as tecnologias permeiam os espaços simbólicos, tendo inclusive a visão da própria linguagem como tecnologia, não haverá de escapar ao observador a influência que exercem sobre identidade, sujeito, coletivo, grupo. Quando os artefatos de memória infotécnicas em rede se esforçarem para encerrar o passado histórico e o esquecimento, presenteificando o passado em um instante urgido, memória e esquecimento se darão ao embate para caracterizar o indivíduo contemporâneo.

Goffman, em seu estudo das representações, destaque-se, intencionais do sujeito em sociedade que objetiva a construção de uma percepção específica sobre si, tratará das estratégias de reconhecimento e, inclusive, indicará um acordo entre ator e plateia ou interlocutores, para que haja maior leveza nas relações interpessoais e elas se tornem possíveis pela redução consentida das agressividades que se dariam caso todos os indivíduos tivessem que, a priori, comprovar que são plenamente dignos e legítimos dos papeis que pretendem desempenhar durante qualquer diálogo.

Assim, o autor apresenta o aspecto intencional das formas de representação cotidianas. 
Esta forma de controle sobre o papel do indivíduo restabelece a simetria do processo de comunicação e monta o palco para um tipo de jogo de informação, um ciclo potencialmente infinito de encobrimento, descobrimento,revelações falsas e redescobertas. Dever-se-ia acrescentar que, como os outros provavelmente não suspeitam, em termos relativos, do aspecto que se supõe não intencional da conduta do indivíduo, este pode ganhar muito controlando-o. Os outros, por certo, podem perceber que o indivíduo está manipulando o aspecto supostamente espontâneo de seu comportamento e procurar no próprio ato da manipulação alguma variação da conduta que o indivíduo não tenha conseguido controlar. (GOFFMAN, pág. 20)

Com esta visão, facilmente nos questionaríamos se este não seria um desvio do tema conquanto a identidade não esteja se apresentando aqui como algo pelo qual o indivíduo identifica a si próprio, ou seja, na medida em que a identidade não seja apenas algo negociado com os interlocutores, mas que uma parcela esteja cimentada na defesa de algo que defina seu lugar de fala para si próprio.

Se sim, este ator de Goffman estaria, então, atuando em sociedade, mas haveria uma identidade verdadeira que intenciona algum lucro, ainda que por artifício de engodo ou simulação, no relacionamento com grupos específicos. Isso pode ser visto de duas formas convergentes.

A princípio, resgata-se uma resposta que pode esclarecer melhor sobre a veracidade de uma identidade específica. Interpelado, Bauman ouve de seu interlocutor que haveria a possibilidade do indivíduo criar falsas identidades para se comunicar pela internet, algo possivelmente similar ao que nos questionamos há pouco. Então o autor repele o argumento dizendo “'falsas identidades'... mas só pode dizer isso pressupondo que exista algo como uma única 'identidade verdadeira'.” (BAUMAN, pág. 96).

Então, um segundo caminho para entender se a aplicação intencional de um discurso produzido objetivamente pelo indivíduo como sendo parte da sua identidade, o próprio Goffman dá seus contornos.

Num dos extremos, encontramos o ator que pode estar inteiramente compenetrado de seu próprio número. Pode estar sinceramente convencido de que a impressão de realidade que encena é a verdadeira realidade. Quando seu público está também convencido deste modo a respeito do espetáculo que o ator encena - e esta parece ser a regra geral - então, pelo menos no momento, somente o sociólogo ou uma pessoa socialmente descontente terão dúvidas sobre a "realidade" do que e apresentado. (GOFFMAN, pág. 29)

Então a intenção, como movimento, como construtora, está incluída na avaliação do que vem a ser a identidade, e se, havendo, quais são os seus contornos. É possível retornar à origem do que hoje discutimos como sendo a identidade em sua manifestação primeva, a identidade nacional. 
Conquanto houvesse, no início da formação dos Estados nacionais, a delimitação territorial e o espaço de aplicação de normas administrativas, o sentimento de nacionalidade não se constitui automaticamente, não se apresenta no mesmo instante da declaração da existência do Estado.

Isso fica ainda mais evidente em casos nos quais diversas culturas, etnias e credos estão dentro do mesmo território nacional recém-formado. Assim, a definição da italianidade, a exemplo, é algo que carece, e careceu de um esforço institucional, e que só teve um aspecto mais proeminente com a diminuição das distâncias através dos meios de transporte e comunicação, diminuindo espaços através da aceleração do tempo.

Assim, enquanto os espaços do estado permaneciam intocáveis ou de difícil comunicação, o sujeito do sul não haveria de entender que participava ele da mesma declaração identitária que um italiano do norte do país.

Enquanto as comunicações ainda eram difíceis, as características locais eram suficientes para confortar uma percepção do próprio sujeito. Então, tentar entender o motivo que levava os camponeses a não se identificarem com todos os cidadãos legalmente definidos por um dado Estado poderia fazer sentido para o governo, mas pouco se justificava para o indivíduo.

Em outras palavras, quando perguntado sobre sua identidade, este termo pouco compreendido à época, trazia uma dúvida sem lastro para o cidadão comum. Perguntado "quem é você", não incomum em resposta poderia se receber indicações extremamente variadas, e mais comum seria ouvir "eu sou eu", ou "sou daqui".

\begin{abstract}
Afinal de contas, perguntar "quem você é" só faz sentido se você acredita que possa ser outra coisa além de você mesmo; só se você tem uma escolha, e só se o que você escolhe depende de você; ou seja, só se você tem que fazer alguma coisa para que a escolha seja "real" e se sustente. Mas foi justamente isso que não ocorreu aos moradores das aldeias atrasadas e dos povoados da floresta - que nunca tiveram a oportunidade de pensar em mudar de lugar, muito menos procurar, descobrir ou inventas algo tão nebuloso (na verdade, tão impensável) como uma "outra identidade". Sua forma de estar no mundo eliminava da questão da "identidade" o significado tornado óbvio por outros modos de vida - modos que nossos usos linguísticos nos estipulam a chamar "modernos". (Bauman, pág. 25)
\end{abstract}

A criação da identidade nacional retoma um trecho de Bauman citado anteriormente que coloca a identidade do indivíduo no âmbito do conflito, pois ao fundar a identidade nacional como afirmação de uma característica, por contraste, apresenta a negação de outros discursos distintivos.

É como se o Estado insistisse na imposição de uma articulação identitária do Eu, ao contrário de permitir, para cada sujeito a existência de constelações identitárias 
(Blisset). Simultaneamente, este processo desenvolve-se junto à produção individual (perfis gerados sobre características potenciais), em torno de padrões de comportamentos estabelecidos pela análise das informações produzidas no interior das redes de comunicação digital. Enquanto o espaço virtual tem permitido uma profunda diversificação no plano da experimentação subjetiva e nas relações sociais que emergem a partir de situações de flexibilidade identitária, os esforços de regulação do espaço cibernético sob a égide da segurança, têm procurado estabilizar e fundir novamente as noções de sujeito - identidade - organismo biológico. Tal conflito se manifesta, por exemplo, na base das discussões sobre a governança global da internet e dos respectivos mecanismos de controle e identificação dos usuários. (Parra, 2010)

Se pensarmos nos termos mais contemporâneos de Goffman, entendendo as representações intencionais do sujeito em sociedade, este conflito aparece de modo um pouco mais claro.

A projeção inicial do indivíduo prende-o àquilo que está se propondo ser e exige que abandone as demais pretensões de ser outras coisas. À medida que a interação dos participantes progride, ocorrerão sem dúvida acréscimos e modificações neste estado inicial de informações, mas é indispensável que estes desenvolvimentos posteriores se relacionam sem contradições com as posições iniciais tomadas pelos diversos participantes, ou mesmo sejam construídos a partir delas. Parece que é mais fácil para o indivíduo escolher a linha de tratamento que vai exigir de, e estender aos, outros presentes no início de um encontro do que alterar a que está sendo seguida, uma vez iniciada a interação. (Goffman, pág. 23)

Passas-e, a partir deste ponto, a entender que quanto mais lastros o indivíduo tiver, como no caso dos dados salvos eternamente na internet, mais difícil é de se abandonar um discurso que constitui sua identidade e assumir novas formas de acordo com a evolução dinâmica do sujeito.

Assim, a liberdade de expressão do indivíduo, neste caso não especificamente de jornalistas e da mídia, e de certa forma, a liberdade de constituição identitária, acaba sendo contaminada pela redução do espaço de privacidade no qual não apenas a explicitação de características pessoais no tempo presente é um problema a ser enfrentado, mas também os seus reflexos futuros se apresentam como um cerceamento da plasticidade do sujeito, estando atrelado, atado a discursos obsoletos sobre sua constituição passada.

Logo em sua primeira página, Nussbaum inicia sua obra trazendo uma grande reflexão.

Nossa vulnerabilidade à fortuna e nosso senso de valor, novamente aqui, nos tornam dependentes do que nos é exterior: a vulnerabilidade à fortuna, porque deparamos com privações e podemos vir a precisar de algo que somente um outro pode proporcionar; o senso de valor, porque, mesmo quando não precisamos da ajuda e daqueles que amamos, amor e amizade ainda nos importam por si mesmos. (Nussbaum, p. 1) 
Ora, se amor e amizade são valores relevantes mesmo que não estejamos fazendo uso imediato, quanto à privacidade, e mais ainda, os direitos de memória e de esquecimento, os direitos de ser participante potente da criação de sua própria identidade faria parte desta lista?

Se outrora o acaso, ou em momentos oportunos, o afeto, amor, amizade, ou até mesmo seus opostos desafetos, regiam os encontros e as trocas simbólicas, a comunicação na contemporaneidade tem diversas novas frentes que distorcem esta lógica de acordo com suas próprias regras e podem acabar reduzindo a serendipidade.

No caso do Facebook, o algoritmo leva em consideração, majoritariamente, três itens para apresentar conteúdos que julga interessantes para cada pessoa em sua rede. A afinidade entre os indivíduos, a relevância de cada postagem e a sua recência, como indica Pariser.

A solução do Facebook foi o EdgeRank, o algoritmo por trás da página inicial do site, que traz as Principais Notícias. O EdgeRank classifica todas as interações ocorridas no site. A matemática é complicada, mas a ideia básica é bastante simples, baseando-se em três fatores. O primeiro é a afinidade: quanto mais próxima a nossa amizade com alguém [...] maior será a probabilidade de que o Facebook nos mostre suas atualizações. O segundo é o peso relativo de cada conteúdo. [...] O terceiro é o tempo: itens mais recentes têm mais peso do que postagens mais antigas. (Pariser, p. 39)

Relevante destacar que o único item mais claro é justamente o último, a recência. Os outros dois pilares majoritários, afinidade e relevância são fatores subjetivos que, convertidos em métricas objetivas, acabam sendo calculados. O Facebook pretende identificar o nível de amizade entre as pessoas, seja lá o que for que isso signifique para a rede. Pode-se arriscar alguns palpites, mas entre eles deverá estar, possivelmente, os indicadores referentes ao tempo aplicado em interagir com um perfil dentro da rede ou mesmo os cliques que ocorrem em suas publicações. Mas esta interação direta, declarativa, não está obrigada a refletir os interesses das pessoas.

O indivíduo que se comunica e acessa o mundo via Facebook está permitindo, mesmo que inconscientemente, que sua visão de mundo passe por um viés algorítmico do qual pouco tem conhecimento. No máximo, ao se dar conta das omissões, pode tentar ludibriar o sistema, mas sempre apenas por pressuposições.

Um jogo de visibilidade e ocultação acaba por tomar lugar entre as interações.

Quando deixados por conta própria, os filtros de personalização servem como uma espécie de autopropaganda invisível, doutrinando-nos com as nossas próprias ideias, amplificando nosso desejo por coisas conhecidas e nos deixando alheios aos perigos ocultos no obscuro território do desconhecido. (Pariser, p. 19)

O indivíduo mantido no centro da bolha de filtros pode ter suas características artificialmente ampliadas por uma redundância de comunicações confirmatórias de sua visão 
de mundo, ou ainda, ter seu entorno comunicacional transformado com base em pessoas que possuem um comportamento similar na rede, mas que em última instância não são este indivíduo único. A identidade, que é permeada pela comunicação, e o discurso, que é permeado pelos traços identitários e distintivos, estão tocados por filtros sutis.

Questiona-se, novamente, em que medida há liberdade ao indivíduo para construir sua subjetividade em estruturas voltadas ao espetáculo e à performance econômica das redes mercadológicas ou da vigilância cibernética.

Mais do que a liberdade como um ente das sociedades contemporâneas, ou da memória, privacidade (se é que há ainda contornos para tratar de modo claro deste termo) e esquecimento, como uma conquista de um espaço restrito de subjetividade pessoal lastreado pelo coletivo poderá ser feita para garantir um campo de atuação e existência parcialmente autônomo?

Antes lastreado fortemente pelo seu aspecto mais proeminente, a saber, o biológico, o indivíduo interagia com o ambiente em estado de harmonia como uma parte constituinte, reagindo por instinto e armazenando as agressões e interações vividas em uma estrutura biológica que buscava ser a mais apta a sobreviver, que lhe garantiria reflexos instantâneos, momentâneos, para cada encontro de risco, para lidar com cada perigo, mas ainda não lhe trazia o aparato necessário para que estivesse liberto das condições materiais da presencialidade.

Com a linguagem, o vínculo entre a ação e o momento presente começa a se romper, como citado no início deste trabalho. Começamos a falar de ato comunicativo, então.

O encontro com cada risco pode ser antecipado, premeditado, calculado, e quando este encontro se realizava, o estratagema articulado por dias e noites é colocado em prática, e este já não poderia mais ser chamado de um encontro casual, natural, pois ali estava o representante da natureza, um alce, uma serpente, uma fera bestial, e em si a própria natureza, e o homem, que já não lhe pertencia, que já não estava mais entre seus membros, e que dava seus primeiros passos neste afastamento que se amplia a cada dia. Se o cérebro se divide entre o pensamento rápido e devagar, como apresenta o premiado Kahneman (2011), parte das condutas humanas ainda seguirão uma gama diversa de vieses.

A linguagem veio a substituir o objeto, o fato duro.

Se se deve prestar as devidas honras ao materialismo histórico, aqui se dirá que a própria linguagem se colocou no lugar do objeto, substituindo-o com sua materialidade. 
Enquanto o objeto, como fato duro, é aquilo que só poderia ser, em sua realidade material, exata, precisa, a linguagem cria um outro objeto, que pretende significar aquele primeiro, mas que de forma alguma é, em si, o objeto que representa.

Aqui, o encontro com a besta foi substituído pelo encontro com a linguagem, com o objeto que representa a besta na memória linguística.

Com a matéria que compõe a linguagem para construir inúmeras feras, tantas quanto forem necessárias, o homem se prepara, articula, organiza seu grupo, e no momento fortuito do encontro, subjuga a ameaça.

Quando isso ocorre, vemos hoje com mais clareza, o que se passa não é apenas a separação do homem da natureza pela linguagem, por si só, nem tão pouco a vitória momentânea sobre uma ameaça presente.

Acontece, ali, uma inversão, pela qual o homem passaria a dedicar suas energias para subjugar a natureza, para se sobrepor a ela, para sobreviver, para viver, para perpetuar, na busca do encerramento das ameaças e prolongamento da vida.

O ser humano, então, desde sua expulsão do estado de natureza, vem buscando descobrir quem é, quem foi e quem será, em um duelo injusto contra o tempo, ou como poderíamos entender facilmente pelas palavras de Santo Agostinho, contra si próprio, já que este tempo só existe para o autor enquanto produto do próprio homem. Na medida em que olha o passado em busca de explicações que possam lhe justificar de que modo pôde chegar ao presente vivido, atua cotidianamente em um jogo discursivo e dinâmico.

Trata-se aqui, então, de uma miríade de possibilidades atreladas ao modo como o indivíduo se percebe em uma matriz de tempo e espaço que o identifica, cartesianamente, trazendo condições para que ele porte e se comporte de modos específicos.

Para entender, ainda que sob seus traços mais singelos, este indivíduo, será preciso traçar alguns caminhos dentro do conhecimento científico, a fim de trazer à baila algumas estruturas sociais, psicológicas e tecnológicas que envolvem e permeiam este sujeito, na busca de um olhar que possa esclarecer, como em um efeito Moébius, o exterior e o interior deste ator que há muito vem agindo em sociedade e que conteporaneamente enfrenta transformações de ordem tecnológicas em um nível tão profundo que estão a produzir rupturas em ritmo acelerado, deslocando o ponto de intersecção, o ponto de identificação deste sujeito, e violentando seu presente próprio com a inserção de um presente tecnoinformático que não lhe permite soltar algumas amarras do passado discursivo. 
A proposição de Lévy, então pensando sobre as inversões da cibercultura, dirá que

Além da desterritorialização, um outro caráter é frequentemente associado à virtualização: passagem do interior ao exterior e do exterior ao interior. Esse "efeito Moebius" declina-se em vários registros: o das relações entre privado e público, próprio e comum, subjetivo e objetivo, mapa e território, autor e leitor etc. (Lévy, 1996, p. 24)

Privado e público, real e virtual, invasão e evasão dos dados. As fronteiras estão se desconstruindo mas os olhos estão vidrados no espetáculo imagético da sociedade contemporânea.

Ao referenciar Tadeu da Silva, Santaella destaca que "não existe sujeito ou subjetividade fora da história e da linguagem, fora da cultura e das relações de poder." (Santaella, 2004, p. 17). Destaca-se, então, a questão da cultura e das relações de poder, para este estudo, na formação e comunicação tanto do sujeito como de sua subjetividade.

No caso da cibercultura dromocrática, este viés está sob o jugo do imperativo da dromoaptidão. Ainda em Santaella, é possível encontrar que

[...] no lugar dos antigos "sujeito" e "eu", proliferam novas imagens de subjetividade. Fala-se de subjetividade distribuída, socialmente construída, dialógica, descentrada, múltipla, nômade, situada, fala-se de subjetividade inscrita na superfície do corpo, produzida pela linguagem etc. Nessa mudança, o psicológico abandona o espaço privado e intransferível das psiques individuais para alojar-se nas encruzilhadas e nas ruelas que marcam o estar-no-mundo com outros seres humanos. (Kvale apud Santaella, 2004, p. 17)

Na sociedade permeada por meios de comunicação digitais, será preciso, antes de mais nada, pensar em que medida as estruturas infotécnicas poderão pressionar os sujeito e contorcer seus traços e discursos identitários com base dificuldade profunda, e do alto custo, de se encerrar um passado indesejado ou mesmo inverídico, ainda que a questão da veracidade não esteja posta de modo abrangente nesta obra.

Quando esta análise pretende tratar da abrangência desta pretendida e às vezes acreditada liberdade de escolha tanto do esquecimento, quanto de seu derivado, a possibilidade de rememorar e reconstruir sua história de modo humano, há a realidade material e objetiva de cada sujeito que se pretende livre, conquanto será necessário, desta maneira, haver um esforço de trazer à luz alguns fatores do discurso identitário, da construção discursiva do próprio sujeito que pretende não apenas a liberdade, mas também a manutenção de seu espaço particular, privado, restrito, se é que haveria um local, ou tempo, em que o sujeito social pudesse se desvencilhar do outro, da sociedade, e agir irrelevando completamente as estruturas sociais que o oprimem a cada instante, mas a este ponto será dada a devida atenção em seu momento oportuno. 
Parte da realidade que ações e palavras adquirem é por se tornarem um registro, um traço permanente que pode circular indefinidamente no âmbito dos fluxos de informação e assim serem reproduzidas em muitas mídias e contextos diferentes. No momento em que palavras e ações tornam-se públicas nesse espaço, o são para sempre - "imortais", mas num sentido bem diferente do tipo de imortalidade de que Arendt imaginava ao escrever sobre os antigos gregos e a significação que vinculavam ao trabalho e às tarefas imortais. De forma similar, "a esfera privada" consiste nos territórios do self sobre os quais o indivíduo procura exercer controle e restringir acesso de outras pessoas. (Thompson, p. 29 - 30)

Só seria válido, insta ressaltar, o estudo das pressões na rede ao passo que se acredite tanto na polivalência dos termos memória, liberdade, esquecimento, vigilância, pois justamente as fronteiras entre o que é domínio do eu e aquilo que deve estar sob domínio público se fragmentaram, assim como tantos outros conceitos, alavancando a dificuldade de enclausurar suas definições e ocorrências em um curso padrão e definido.

Em outras palavras, conquanto tratemos cotidianamente de condutas ou direitos aos quais rotulamos por memória e esquecimento, de construção identitária ou identidade coletiva, por exemplo, ainda assim não estamos descendo às zonas abissais nas quais tais conceitos tentam manter alguns de seus lastros.

Assim, tentando compreender o presente, ronda a mente de modo consciente que parte do que está apresentado aqui é também um estudo do passado-presentificado. Novamente recobrando as palavras agostinianas em um esforço para que este passado esteja o mais próximo possível do presente contemporâneo, mantendo, à medida que nos cabe, a profundidade desejada para que não estejamos apenas pincelando o presente com a leviandade característica dos discursos sobre o novo tecnofílico, ao passo que além de novo, este também seja o desconhecido considerado e pensado como sua partícula oculta em cada ruptura que se apresenta ao homem observador.

O culto ao novo não pode tomar o lugar da reflexão, vale ressaltar. Felinto dirá, ainda, que "[...] os discursos da inovação tecnológica, especialmente no âmbito das tecnologias digitais, partem frequentemente de uma tabula rasa do tempo. Nada existia antes do novo e nada existirá depois, senão ele mesmo.” (Felinto, p. 44)

Então, da análise deste sujeito que está em busca de seu modo de se apresentar e ser nas sociedades contemporâneas, mas que nem sempre percebeu o impacto das estruturas infotécnicas na sua ecologia identitária e nas possibilidades ou impossibilidades materiais de memória e esquecimento, neste trecho será, então, necessário avaliar brevemente o entorno do indivíduo, e como tal, não apenas a sociedade, mas como pede claramente esta proposta, os 
seus aspectos tecnológicos, e predominantemente, aqueles que estejam intimamente ligados aos meios de comunicação e expressão desta individualidade pretendida.

Tecnologia, então, é fator basal nesta análise para que se perceba ao menos de modo minimamente mais capacitado para seguir adiante e olhar como o sujeito integrado às tecnologias está colocado, identificado, presente na contemporaneidade e como ele, além de agir, pensa sobre esta ação, sobre seu eu e sua identidade, fatores que estão nas veias das questões do esquecimento e da memória.

É na realidade compartida, reconstruída no presente entre sujeitos com vínculos, trajetos biográficos, imagens e interpretações concretas dos acontecimentos históricos, que construímos laços e boa parte das nossas sociabilidades. [...] Este passado, reiteradamente significado, opera como uma "força memorial" (Wieviorka) em que a partilha de narrativas e as releituras de acontecimentos sugerem uma pressão social sobre o papel da História. Em particular desde o desvelar das "memórias subterrâneas" (Pollack); essas interpretações minoritárias ou suprimidas do discurso público,subalternas às visões mais consensuais, normalizadas e oficiais da construção do passado. Esta evidencia sociohistórica teve a sua expansão no período posterior as guerras mundiais, na amplificação mass-mediatizada dos relatos, o que fez emergir a "era do testemunho" (Wieviorka). (Reis, p. 10)

Assim, retomando e avaliando desde o esforço do Estado moderno em constituir uma identidade nacional até os discursos atuais propostos pelo próprio indivíduo, chega-se ao momento de avaliar como este agente comunicante se afirma em plataformas de comunicação e com suas estratégias discursivas e, assim, como se percebe, transita entre diferentes identidades, com traços cada vez mais sutis, e que agora toma sua energia de modo ímpar na construção de um ou de muitos "eus" nas representações em sociedade em alguns casos passados e como ainda defendem muitos autores, em condições técnicas contemporâneas.

É neste ponto do debate que será possível ver um fator complicador para a construção discursiva deste sujeito, que busca, vale citar, a sua construção tanto no campo das representações públicas, ou seja, para seus pares em sociedade, quando no âmbito pessoal, enquanto sujeito que anseia por conhecer a si próprio e segue nesta busca constante e interminável, posto que ainda que entenda traços graves e robustos de sua personalidade de modo consciente, ainda restará tanto as sutilezas, que se transformam cotidianamente, quando as estruturas mais animalescas do seu caráter, ou ainda as fontes no inconsciente de suas ações e traços visíveis, ou não, a olho nu.

A habilidade dos indivíduos em exercer controle sobre seus territórios do self e de restringir o acesso a eles é constantemente posta em cheque, e em alguns contextos, comprometida pelo fato de que os outros podem se valer dos novos meios tecnológicos, políticos e legais - para ter acesso, conseguir informações, explorá-las em benefício próprio e, em algumas ocasiões, torná-las públicas. As fronteiras mutantes entre a vida pública e a vida privada tornam-se um novo campo de batalha nas sociedades modernas, um terreno disputado em que os indivíduos e organizações 
travam um novo tipo de guerra da informação: usando de todos os meios disponíveis para obter informações sobre os outros e para controlar as informações sobre si mesmos, muitas vezes esforçando-se para lidar com mudanças que não puderam prever e com agentes cujas intenções não puderam entender. Trata-se de um terreno em que as relações de poder estabelecidas podem ser abaladas, vidas podem ser prejudicadas e até, em alguns casos, reputações podem ser perdidas. (Thompson, p. $30-31$ )

$\mathrm{Na}$ medida em que este ponto foi abordado anteriormente nas estruturas de dados, é também, além da tecnologia em si, mas no plano das construções discursivas, onde o esquecimento e a memória estão se transformando e se recombinando. Quando esquecer e lembrar passam por uma inversão inédita como a proposta por Pariser, as bases majoritárias de uma sociedade e mesmo natureza econômica acabam por inverter o padrão de esquecimento em uma memória compulsória.

Este fator complicador se mostra mais evidente quando se entende que não faltassem as múltiplas possibilidades de ocorrências no presente, onde o sujeito tenta se enxergar e agir, há ainda que se tratar de suas expectativas sobre o futuro, além de suas amarras do passadopresente.

Assim, o sujeito barrado do discurso lacaniano, que tenta obturar a hiância, ou a falta primordial muitas vezes tratada na filosofia pelos tempos, é o sujeito que aceita suprimir o impulso natural de sorver o prazer momentâneo em busca de um prazer ou bem maior no futuro, ou seja, o sujeito projetivo que age em busca de algo que está no âmbito não apenas das possibilidades quanto do discurso, e como discurso, ele age. Este é o sujeito, uma vez mais, vigiado e que está sendo estimulado a não sorver amanhã, a comunicar agora. E quando a pressão e a vigilância atuam, não o fazem depois. "The panopticon shapes present behavior: I act as if I am watched even if I am not.” (Mayer-Schönberger, p. 11)

Ao perceber a dromoaptidão, o indivíduo poderá sentir sua presença até em traços mais sutis e, ao pensar na vigilância, poderá encontrá-la até onde os dispositivos infotécnicos ainda não conseguiram integrá-la, temendo por seu presente e por seu futuro.

Em adição a esta avaliação do futuro, é necessário lembrar não apenas da visão, novamente projetiva, sobre o futuro próximo do homem tecnicizado, quanto dos fatores de complexificação que o digital traz, passando pelas palavras não apenas de McLuhan, Keckhove, Lévy e Castells, mas também pelo que se tem estudado e, como não seria diferente com temas tão novos e de transformação tão veloz, especulado pelo mundo em torno do que será a humanidade com base no que se mostra possível nos dias atuais. 
Há muito se estuda os impactos dos meios de comunicação não apenas na sociedade, mas também na própria mensagem transmitida e, como muitos dirão, alterada e contaminada por eles, como a corrente da Escola de Toronto propõe.

Da mesma forma, a ecologia dos meios de comunicação é estudada como fator de influência na forma como o sujeito se constitui e como articula seus discursos identitários com base na complexa gama de meios e de significações das linguagens, termo que neste momento ganha um contorno maior do que a língua, abarcando as linguagens comunicativas que engolfam todas as formas de transmissão de informação e, de certa forma, de diálogo.

$\mathrm{Na}$ mesma seara, estão os estudos que tratam da características específicas de cada meio de comunicação, avaliando canais como sites ou aplicativos específicos que fazem parte das redes sociais.

Ao combinar a estrutura de ambos os estudos, tem-se um olhar sobre algo que é transversal a eles. O sujeito, sua potencialidade discursiva, ao mesmo tempo, as pressões e coerções que sofre e que pratica.

De modo mais claro, é de se avaliar o que se relacionou como sendo a liberdade ao longo do tempo, para que, aplicada a ela e ao discurso identitário, esteja também posta a questão do esquecimento para a reconstrução do eu discursivo e agente na ecologia comunicacional contemporânea.

Somado a isso, há as possibilidades múltiplas de armazenamento e cruzamento de grandes quantidades de dados sobre os indivíduos de modo identificado, em muitos casos, ou de modo identificável em quase sua totalidade. Visão esta que nos coloca na sociedade da hipervigilância de Foulcault sem a menor cerimônia e, o que pode ser um tanto quanto mais alarmante, sem o menor aviso concreto e claro.

Embasa a relevância deste estudo os escândalos recentes envolvendo a NSA, ou como bem cita Assange, que

A vigilância não constitui um problema apenas para a democracia e para a governança, mas também representa um problema geopolítico. A vigilância de uma população inteira por uma potência estrangeira naturalmente ameaça a soberania. (Assange, p. 20)

E indo um pouco além, não é apenas a soberania que está ameaçada, apontada com mais destaque por Assange por seu apelo político, mas também a soberania, se é que se pode tratar desta maneira, do indivíduo sobre si, sobre seu espaço e sobre seu domo sendo transpassado pela dromo. 
Adicione-se, ainda, a forma de atuação de grupos como o Anonimous, o fortalecimento de ações e condutas como a apresentada pelos membros do Wikileaks, mas muito além disso, muito além dos conflitos entre embaixadas ou entre governos, é pauta categórica o debate sobre as formas de vigilância sobre o cidadão, não pelo seu aspecto militar e bélico, que também pode ter seu espaço, mas neste caso principalmente por sua força e pressão sobre a história, memória e esquecimento sobre os indivíduos e grupos.

O que está em questão, então, não é apenas se há ou não a vigilância sobre o cidadão/cliente, mas como esta vigilância extrapola estes dois papéis e interfere sobremaneira na constituição do sujeito, agora atingindo o grau aprofundado que e sobrecarregado de simbolismos e valores que esta análise pede.

Conquanto as empresas sejam tecnicamente capazes de avaliar os dados próprios há anos, os tempos atuais mostram um aprofundamento ainda tímido, mas com caminhos possíveis para a computação quântica e seus derivados, o que pode trazer para mais perto os dias em que os dados antes enclausurados em planilhas intermináveis, que eram guardados nas fortalezas protegidas, passem pouco a pouco a abandonarem seu isolamento e possam fazer parte de um sistema maior que cruza cada dado entre grupos e sistemas, entre empresas, e trace perfis comportamentais com extrema precisão, transformando parte da trajetória do internauta em uma profecia autorrealizável.

Ainda que o debate sobre o Marco Civil da Internet tenha atingido seu ápice há pouco mais de um ano, torna-se perceptível que seu texto ainda esteja muito aquém dos debates necessários para salvaguardar não o direito de cidadania ou a proteção paternalista do cliente, mas como se discute nesta obra, o direito a ter um lugar de fala próprio, de se construir como sujeito, de articular um discurso não determinado nem determinista.

Para tanto, será preciso atentar não apenas para o que se veicula na mídia ou os teóricos da comunicação, mas ainda estudar à luz do direito as formas de atuação em sociedade de um sujeito exigido de conhecer as leis sem desculpas, e como tal, exigido de uma clareza sobre sua identidade e seus atos, suas necessidades e condutas que certamente continuará titubeante e lacunar para os próximos anos se o caminho dos legisladores não sofrer qualquer grande mudança não apenas no Brasil, mas em grande parte do mundo.

Neste escopo, está o grande debate sobre a posse e propriedade de dados, que esbarra, tanto quanto, no direito do uso de imagem e direitos autorais, bem como a avaliação dos 
termos e condições de uso de algumas redes específicas, como o caso, novamente, da Facebook, por exemplo.

A identidade como nome único e público é o conceito de rótulo e vínculo único, mas a constituição contemporânea de identidades irá além do quesito formalista de poder ser reconhecido, tratando antes de tudo, de poder existir como sujeito comunicante e negociador de significados.

No contexto da percepção seletiva, Wolf resgata Cooper e Johada (apud Wolf) para indicar uma das formas de não encarar, através das formas de comunicação, alguns fatos indesejados.

\begin{abstract}
O conhecido estudo de Cooper e Johada (1947) sobre as possibilidades de sucesso de uma série de desenhos animados ao se imprimir um significado antirracista no comportamento preconceituoso dos indivíduos revela justamente uma reação comum para fugir do problema é a de 'não compreender' a mensagem. O que as autoras chamam de derailment of understanding (ou 'compreensão aberrante) pode seguir várias estratégias, entre as quais, por exemplo, a aceitação superficial do conteúdo do desenho animado, exceto para reforçar que em algumas circunstâncias concretas os preconceitos se justificam, ou para atribuir à mensagem uma representação incorreta da realidade, ou para qualificar a história representada pela mensagem justamente como sendo 'apenas uma história', ou, enfim, para modificar o quadro de referência da situação narrada pelo desenho animado. (Wolf, p. 24-25)
\end{abstract}

Da mesma forma podemos questionar se a percepção individual da vigilância e do cerceamento da constituição identitária é percebida e, além disso, se quando percebida, esta compreensão se faz igualmente aberrante, fugindo do aprofundamento necessário para levar a cabo o debate sobre que identidades e que histórias pessoais são passíveis de serem construídas nos dias atuais, contando com uma rede telemática de memória que se pretende onipresente e onisciente.

Com os dois pilares, a presença e a ciência dos "fatos", o que se coloca na berlinda e sob os holofotes para o escrutínio é justamente o tamanho do poder das redes de dados em fazer lembrar e esquecer.

Ainda que se deva fazer a ressalva de que a rede de computadores e de bancos de dados na nuvem não seja realmente sequer onisciente, quem dirá onipresente, já que tal completude, totalidade do saber não está nem estará dada, o que se percebe é que as informações estão não apenas mais disponíveis, mas também culturalmente a sua entrega vem sendo estimulada e sutilmente aceita, como tratado em alguns momentos nesta obra.

Nesta medida, o saber a respeito de cada indivíduo e a copresencialidade deste saber, bem como através das características constitutivas da simbiose cíbrida baseadas nas 
tecnologias de comunicação contemporâneas, a heresia está à beira das trombetas dos arautos. Ciente e presente, o quão potente é a cibercultura e sua dromocracia?

Em outras palavras, o que outrora fora referenciado como característica da divindade está sendo sutilmente escamoteado pelos fluxos transnacionais de informação tanto quanto pelo imperativo dromológico da comunicação interpessoal e interagentes, sejam eles sujeitos com lastro orgânico (seres humanos), sejam eles produtos das programações humanas em evolução pelo aprendizado artificial. Onipresença, onisciência e onipotência postas na mesma mesa para serem avaliadas por seus pais, que se tornam tutelados pela tecnologia, de certa forma, e compelidos a engrossar a horda cibercultural dromoapta.

Wolf, com isso, ao trazer a questão do entendimento aberrante daquilo que se apresenta está, em seu levantamento histórico, destacando o que hoje pode ser lido com outras cores.

A quem vale o debate sobre as violências que o ecossistema cibercultural carrega e aplica se não aos deslocados, que em um distanciamento procuram vislumbrar os lampejos das teias infotécnicas e o caráter restritivo do acesso às suas senhas, obsolescentes, queixosas da vagarosidade do tempo humano.

\subsection{IMAGINÁRIO, IMAGEM E IDEOLOGIAS}

Antes de mais nada, terá destaque a visão de que a tecnologia não pode ser vista apenas pelos seus aspectos infotécnicos, mas atrelada a uma cultura, que para os objetivos deste estudo, alinha-se à cibercultura, e a uma sociedade, que é justamente a sociedade contemporânea.

[...] não há teoria da comunicação sem uma teoria implícita, ou explícita, da sociedade, e que jamais é possível pensar um sistema de comunicação sem relacioná-lo às outras duas características: cultural e social. É nesse sentido, também, que o desafio para as novas tecnologias de comunicação é atribuir-lhes uma dimensão social, e não tecnologizar o homem ou a sociedade. Em poucas palavras, tirar a comunicação de uma problemática da performance. (Wolton, p. 16)

Ou seja, tecnologia, cultura e sociedade estão no tripé woltoniano da comunicação. E sem elas, qualquer análise estaria vacilante e teria sua queda facilitada.

Ao pensar nos enclausuramentos apresentados anteriormente, combinando esta amálgama tecnológica e cultural com a sociedade e seu elo, o indivíduo, há de se compreender que mesmo as estruturas mais restritivas e castradoras terão que enfrentar a força imaginal, mas nem por isso estará desamparado o indivíduo para, com sua própria e única força, resistir às estruturas coercitivas da cibercultura dromocrática. As tecnologias do 
imaginário tomarão parte na dinâmica de lutas que se dará em meio a cibercultura e nos espaços cíbridos.

\begin{abstract}
As tecnologias do imaginário são dispositivos (Foulcault) de intervenção, formatação, interferência e construção das "bacias semânticas" que determinarão a complexidade (Morin) dos "trajetos antropológicos" de indivíduos ou grupos. Assim, as tecnologias do imaginário estabelecem "laço social" (Maffesoli) e impõem-se como o principal mecanismo de produção simbólica da "sociedade do espetáculo" (Debord). (Silva, 2012, p. 20-21)
\end{abstract}

A interferência das tecnologias do imaginário estão apresentadas por Silva, na voz de tantos autores, para indicar com maior clareza o papel seminal de tais tecnologias, mas o seu encerramento traz justamente sua conclusão na sociedade espetacular debordiana, o que trará à luz do debate o papel da imagem, do escopismo, na construção das consonâncias e rupturas estruturas da cibercultura, bem como do imaginário, em si.

Se Silva acaba por conectar o imaginário, nesta citação acima, com Debord, pode indicar a cooptação que o capital e a imagem espetacular debordianos fazem inclusive do imaginal, em um segundo passo, mas que não podem impedir, a princípio, que este imaginal acabe por fazer tremer as estruturas determinadas e determinantes. Desta forma, adicionando uma nova trilha ao caminho do debate sobre a imagem e seu papel na conformação ou transformação das estruturas ciberculturais, Wolton pode servir de auxílio. Para ele, "a imagem não existe nunca por si mesma. Ela está inscrita em um contexto, tem um antes e um depois. Essa inscrição opera inevitavelmente uma relativização." (Wolton, p. 41)

\footnotetext{
Quanto à imagem, perde sua exterioridade de espetáculo para abrir-se à imersão. A representação é substituída pela virtualização interativa de um modelo, a simulação sucede a semelhança. $\mathrm{O}$ desenho, a foto ou o filme ganham profundidade, acolhem o explorador ativo de um modelo digital, ou até uma coletividade de trabalho ou de jogo envolvida com a construção cooperativa de um universo de dados. (Lévy, 1999, p. 150)
}

Quando Lévy se permite indicar que a imagem, dentro da cibercultura, perde sua exterioridade de espetáculo, está a dialogar com Debord, mas que conflita diretamente com a afirmação deste, que quase uma década antes fora categórico. "O espetáculo é o capital em tal grau de acumulação que se torna imagem.” (Debord, p. 25). Se Lévy admite a imagem espetacular debordiana, e em contrapartida indica sua mudança, sua abertura, precisaria indicar também em que maneira o capital deixou de se acumular a ponto de ser a imagem. Em uma inversão, a imagem estaria despida, na cibercultura, do peso do capital. Lógica que seria diametralmente oposta.

Em uma sociedade de escopismos aflorados, a imagem, polissêmica, estaria atrelada ao contexto. Mas o questionamento que se seguirá durante todas estas páginas se apresenta 
novamente aqui. Qual é o contexto que ressignifica a imagem em uma cultura da aceleração com um suporte técnico determinado a oferecer um presenteísmo contínuo remontado dos fatos passados? A menos que o terceiro item do tripé woltoniano, a recordar, a sociedade, esteja preparada para questionar ativamente o que vem a ser a informação recebida e os estímulos ciberculturais para a agilidade, o filtro ético-moral não poderá se manifestar a contento.

Recai, então, sobre a sociedade, novamente, o dilema. Em tempos de desenvolvimento de inteligências artificiais, que se inserem no âmbito da tecnologia e suas técnicas, a moral e ética ainda estão arraigadas e atreladas às estruturas sociais, mas sendo pressionadas sem muito alarde pelos algoritmos e filtros.

Se o esvaziamento do sujeito se mantiver, graças à aceleração das relações e ao fluxo violento e sutilizado das comunicações, poderá haver o preenchimento deste hiato através da onipresença dos sistemas técnicos e das estruturas de memória e conforto prático. Ponto este em que Wolton dirá, de modo que se possa comparar e trazer para o contexto atual, que "quanto mais a imagem tem diante de si este usuário sem identidade, mais ela é investida de onipotência." (Wolton, p. 42)

Em um desdobramento desta expressão, quanto menos é autor de suas ações e de sua obra, de sua identidade, menos poder terá o sujeito sobre a imagem e, como tanto, sobre a tecnologia e cibercultura.

Mas o confronto, insta ressaltar, não se dá apenas no campo simbólico, do imaginário contra as ideologias, mas também ocorre no nível da vigilância e violência dromocrática. Assim, as Tecnologias do Imaginário (TI) estão contrapostas, de certa maneira, aos Aparelhos do Estado (AE) de que Silva trata ao apontar que

Os AE atualizam e fundamentam o poder; as TI operam no território anárquico da potência. No fundo, Michel Foucault estava falando de tecnologias "suaves" de controle total das consciências e dos corpos, funcionando com base em dispositivos de inoculação, de inseminação, de difusão e de moldagem. Em outras palavras, na busca da "servidão involuntária", fruto de uma pressão e de uma vigilância permanentes. Trata-se de um esquema de reflexo condicionado, operando a golpes de estímulo, recompensa e punição, no qual a possibilidade de escolha é diminuta, embora a coerção física atue em segundo plano, deslocada pela engenharia publicitária das mentes. (Silva, 2012, p. 23)

Importante destacar que a violência citada muitas vezes nestas páginas não é necessariamente física, ainda que não a exclua em sua somatização individual ou coletiva, mas sim uma violência também e sobremaneira simbólica, psicológica e social, na medida que 
é uma violência tecnocultural. Indissociáveis, tecnologia, cultura e sociedade estarão presentes na geração da violência cibercultural dromocrática triviniana.

Para os pensamentos deterministas, tanto tecnófilos quanto tecnófobos, Wolton indica a inexistência de um encadeamento único à tecnologia. Para o autor:

Esta economia do imaginário introduz uma liberdade, ou seja, uma relativização dos dois lados, e anula por isso mesmo a ideia de uma influência unívoca. Entre a intenção dos autores e a dos receptores não operam somente diferentes sistemas de interpretação, de codificação e de seleção, mas igualmente todos os imaginários. [...] Em poucas palavras, o paradoxo da imagem é o seguinte: nós a amamos e a consumimos, porque nós estamos sós diante dela. Livres para amá-la ou rejeitá-la. (Wolton, p. 42)

Tendo sua obra os traços do seu tempo, ou seja, o ano 2000, Wolton ainda não estava plenamente exposto à digitalização dos meios de comunicação, mas já antevia alguns comportamentos. Entretanto, mesmo assim, a tradução das diversas mídias em estruturas digitais acaba não por contradizer Wolton sobre a impossibilidade da univocidade tecnológica, mas em apresentar não um receptor intencionado e totalizador, mas algoritmos que pouco se interessam pela condição humana, mas sim pela performance dos sistemas técnicos. Assim, o digládio não estaria mais apenas entre ditadores ou controladores e a sociedade aviltada. A criatura agora decide o conteúdo que vai formar o criador.

Todavia, mesmo assim, o imaginário guardará sua prerrogativa de descompasso, sua agenda própria, suas movimentações mais profundas. Se a referência fosse lacaniana, esta mobilização afloraria do subconsciente.

A experiência humana contém em elemento criador de natureza metafísica que, sim, concretiza-se em fenômenos materiais e identidades coletivas, mas jamais se reduz a esses elementos, sob pena de eles perderem sua capacidade de renovação. A engenharia é permeada por um elemento imaginário e a inventividade intelectual, em nosso tempo, é cada vez mais tecnológica. (Rüdiger, p. 137)

Com isso, tem-se que a tecnologia faz parte do imaginal, mas este não se restringe àquela. No imaginário a criação não se coloca a respeitar regras arbitrárias da cibercultura, e sequer o fará com a sociedade. Contudo, o imaginal, com suas tecnologias, terás ua própria versão de mundo, e no contato, gerará a crítica, o embate.

Os imaginários difundem-se por meio de tecnologias próprias, que podem ser chamadas de tecnologias do imaginário. [...] Todo imaginário é um desafio, uma narrativa inacabada, um processo, uma teia, um hipertexto, uma construção coletiva, anônima e sem intenção. (Silva, 2012, p. 8)

Salpicado de temperos sociais, cada imaginário, em Silva, se encontrará com os demais nas tecnologias do imaginário de modo rizomático, hipertextual tanto quanto a cibercultura. 
Se não há um centro da cibernética e da cibercultura, o mesmo se dirá de todos os imaginários, que são "[...] um desafio, uma narrativa inacabada, um processo, uma teia, um hipertexto, uma construção coletiva, anônima e sem intenção.” (Silva, 2012, p. 8)

A tentativa de enclausurar o sujeito, então, nas amarras dos dados terá que passar durante todo o tempo pelos campos do imaginário e receberá, entre os impactos, parte de suas cores. Isso significa dizer que a força dromocrática que está a escrutinizar o indivíduo em busca dos dados que usará como artifícios de memória não poderá operar contra este mesmo indivíduo sem que este em dado momento, se não um sujeito, alguns, se rebele ou sinta tal pressão oprimindo justamente seu gérmen imaginal. Com isso, através das Tecnologias do Imaginário, a redução cibernética das comunicações antientrópicas terão suas amarguras.

O conforto da mensagem segmentada terá que lidar com as inconstâncias disruptivas da subjetividade humana.

[...] tudo é cópia, má cópia, deformação, distorção e apropriação, desvio, adulteração e dívida. A cópia sempre trais o original, que nunca foi puro. A necessidade da cópia permeia a criação. Nunca se parte do meio das águas, mas sempre de alguma ponta. Não há centro na teia do imaginário. Todas as estradas desembocam na mesma altura da malha simbólica. Tudo é nó e conexão no tecido imaginal. Cada link, feito um porto, é ponto de chegada e de partida. (Silva, 2012, p. 11)

Esta cópia falha é a marca da impossibilidade de capturar plenamente o sujeito sem distorcer-lhe os contornos e sem deixar em seus registros os aspectos das tecnologias que participaram desta coleta.

Irredutível, sim, mas irrepresentável, não. Se não desce na bacia semântica de modo pleno, ainda assim mistura suas águas.

Podemos encontrar uma dica sobre essas aventuras na palavra grega deinón. Não
existe em inglês uma tradução única disponível para essa palavra. De modo geral,
ela é usada para designar o que inspira admiração e fascínio. Mas em diferentes
contextos pode ser usada para designar o brilhantismo ofuscante do intelecto
humano, a monstruosidade de um mal, o terrível poder do destino, o que é deinón é
de alguma maneira estranho, fora de lugar; sua estranheza e sua capacidade de
inspirar admiração estão intimamente ligadas. (É etimologicamente relacionado a
déos, "temor"; podemos compará-lo com o francês formidable.) Deinón
frequentemente implica uma desarmonia: algo que não se coaduna com o que o
cerca, ou o que se espera, ou o que se deseja. (Nussbaum, p. 45)

Se o que Nussbaum relata sobre a deinón pode ter um paralelo com a cibercultura, este será na sua forma de admiração e fascínio de alguns, e no temor de outros. Agora ao mesmo tempo este paralelo pode servir para indicar a desarmonia que está dentro do próprio fascínio.

O imaginal não se quedará tácito frente à proliferação da cibercultura e das estruturas de vigilância, ainda que esta possa ser internalizada em níveis diferentes por cada ente social. 
O imaginário é uma distorção involuntária do vivido que se cristaliza como marca individual ou grupal. Diferente do imaginado - projeção irreal que poderá se tornar real -, o imaginário emana do real, estrutura-se como ideal e retorna ao real como elemento propulsor. (Silva, 2012, p. 12)

O ponto pertinente que Silva resgata é a indisponibilidade do imaginário para ser cristalizado objetivamente. $\mathrm{O}$ imaginado, em seu presente-passado, pode vir a ser materializado, o imaginal participa da criação e da desconstrução da realidade.

Em outras palavras, é também nos imaginários que as experiências filtradas vão encontrar barreiras. É através do imaginal que o determinismo comunicacional padece, perde seu governo.

\section{DIREITO E ESQUECIMENTO}

Para o encadeamento do tema, tratando do direito ao esquecimento contemporâneo, foi preciso passar por estruturas como a cibernética para compreender sua origem, bem como a gênesis da cibercultura. Da mesma forma, em muitos momentos tratou-se das características mais prevalentes da cibercultura, com base me Lévy e Trivinho, em grande medida, onde encontrou-se, neste último, os aspectos virilianos da velocidade e aceleração oriundos da cibercultura que, como visto, se tornam, velocidade e ciberculura, a estrutura organizatória da sociedade.

“A consolidação transnacional da velocidade como comunicação em tempo real
representa, em si mesma, para além de sua expressão setorial, fragmentária, atrelada
ao território geográfico, a vigência do dispositivo sociodromológico como regime
estrutural e universal, de caráter sistêmico definido, numa palavra, como
dromocracia, em sua tipificação mediática. Nessas condições, o conceito de
dromocracia expressa bem aquilo de que se trata: velocidade técnica e tecnológica
equivale a um macrovetor dinâmico exponencial de organização/desorganização e
reescalonamento permanente de relações e valores sociais, políticos e culturais na
atualidade.” (Trivinho, p. 69)

Cibercultura, então, apresentada em suas características pervasivas, que através das estruturas infotécnicas e da velocidade estará presente nos estímulos de aceleração da forma como o indivíduo se comunica e interage.

Assim, a cibercultura foi colocada como contexto, mas não como pano de fundo a colorir alguns espaços, mas como ente que permeia todos dos espaços de debate pelos quais pretendeu se passar neste estudo.

O esquecimento, tópico vertical deste capítulo, não poderia ser retratado sem que antes pudesse ser mais clara a relação deste com a macroestrutura sociotécnica dentro da qual este se pretende fazer valer suas forças. 
Na sequência, o resultado do olhar sobre a cibercultura levou à percepção da velocidade não apenas como uma relação de espaço-tempo, mas como um imperativo que exige dos agentes que se manifestem, que produzam a comunicação, mas retirando-lhes o tempo de reflexão, de modo que a dromoaptidão passará a vigorar para selecionar aqueles que poderão ter o privilégio de estar, momentaneamente, entre os interlocutores legitimados pela cibercultura.

Nesta monta, como visto, não se encontraria dromoaptos perpétuos mas sim os que conseguiram se apresentar desta forma mas que sofrerão da mesma maneira as pressões da obsolescência e do imperativo da exclusão que opera dentro da dromoaptidão.

Sem o tempo de reflexão e como as cobranças tácitas da cibercultura pela produção e manifestação de dados, de comunicação, na mesma medida que "[...] a velocidade preserva apenas a carcaça dos seres (e ainda assim muito precariamente), destruindo-lhe os processos neuropsíquicos" (Trivinho, p. 99), o fará exigindo que esteja sempre pronto, indivíduo a indivíduo, para responder às demandas dromocráticas.

Desta forma, exilado do espaço transitivo, do tempo longo, cada participante da cibercultura amplia seus riscos de comunicar algo que por ventura não seja a melhor representação de si no momento presente, muito menos em um futuro imaginado mas nunca garantido.

Aqui começa-se a tocar no termo que é objeto final deste estudo, o esquecimento e o direito de conquistá-lo. A problematização abriu os caminhos para uma visão complexa das possibilidades de cerceamento da livre manifestação das identidade e dos anseios das pessoas imersas na cibercultura dromocrática contemporânea mas ao mesmo tempo, após esta jornada, pôde-se perceber que não é apenas a manifestação da identidade que pode estar sofrendo os impactos isoladamente, ainda mais dentro do paradigma da complexidade, mas também as condições disponíveis para a manutenção da polivalência identitária e comunicacional.

Entre os riscos está o filtro condicionado com base nos dados individuais que podem apreendê-lo em um mundo de confirmação das opiniões individuais afastadas da alteridade a cada dia e que também se afasta da serendipidade.

Tal filtro ocasionará o que Pariser chamará de bolha, dentro da qual tudo parece fazer sentido e converge para o conforto e a confirmação, e quando vista pelos olhos de seu provedor de dados, ou seja, o próprio indivíduo, pouco lhe parecerá que está encarando uma visão deturpada da realidade comunicacional. 
Outra face das redes infotécnicas de memória, e portanto de confronto com o esquecimento, é a inversão do custo de coleta e arquivamento dos artefatos de memória, bem como sua facilidade de acesso nos dias contemporâneos, e o investimento necessário para realizar a curadoria deste conteúdo, avaliando aquilo que deve ser descartado para dar espaço ao florescimento de novas narrativas, seja do indivíduo sobre ele mesmo, seja sobre os outros, sobre a sociedade, ou mesmo a versão da máquina sobre o homem. "What we sense is the demise of forgetting, and a fundamental shift to the default of remembering. And while remembering has its indisputable benefits, too much of it may lead to terrible consequences." (Mayer-Schönberger, p.11) O autor continuará, ao indicar que "forgetting is not just an individual behavior. We also forget as a society. Often such societal forgetting gives individuals who have failed a second chance.” (Mayer-Schönberger, p. 13)

Houve ainda a questão das redes de dados se comportarem espetacularmente como um aparato de conforto e praticidade, mas em sua outra face, oferecer as condições para a potencialização e dispersão das estruturas de vigilância, seja para atender aos objetivos mercadológicos, através da publicidade, por exemplo, seja para atender aos objetivos bélicos.

Neste quesito, o esquecimento estará comprometido na medida em que um aparato amplo de artifícios está tomando até os rincões mais ermos da internet para rentabilizar esforços da produção, coleta e distribuição de conteúdo na rede através da venda de dados ou, se não de modo direto, de forma indireta, aplicando as camadas de coleta e rotulagem de informações de empresas interessadas em minerar estes dados e gerar um produto ainda mais vendável para saciar o mercado.

E destaque-se, tal prática tem o potencial de interferir não somente nos espaços virtuais, mas pode, tanto quanto o faz, atingir os diversos nós conectores do indivíduo à sociedade e sua visão de si próprio.

O filtro de Pariser funcionaria de modo pantópico, ajustando os conteúdos de anúncios e páginas ao perfil imaginado de consumo de informação, fazendo com que a internet esteja, de modo exageradamente extremado aqui, dedicada a segmentar e prover a melhor experiência a cada instante para cada pessoa de modo individualizado. Agora se a felicidade é a melhor métrica de sucesso da sociedade contemporânea, esta é uma resposta que não caberá ser dada neste escopo.

Da mesma forma, com dados coletados, ainda que a capacidade de processamento das empresas e governos ainda não seja capaz de ir muito a fundo nos cruzamento de dados sobre 
toda a população vigiada, isso não significa que os dados antigos não poderão ser revisitados na medida em que a capacidade tecnológica avança. Assim, um ato executado a poucas semanas poderá reverberar na imagem que o governo faz de um indivíduo daqui décadas.

Assim, para que o imaginário aflore e as resistências infotécnicas sejam reduzidas, o esquecimento passa a ser uma bandeira que raramente fora hasteada.

Se antes a memória era de difícil acesso, hoje é o esquecimento que faz falta pelas infovias.

Esquecer é ter a capacidade de descartar da memória aquilo que já não é importante, dando mais espaço às lembranças que são efetivamente relevantes. $\mathrm{O}$ direito ao esquecimento está relacionado ao uso e armazenagem de informações pessoais sigilosas (como números de documentos, históricos médicos, profissionais, etc.), mas também toca toda a trajetória de vida do indivíduo - desde antecedentes criminais a questões de relacionamentos íntimos e violências sofridas. Saber identificar até que ponto tais informações têm importância suficiente que justifique sua exposição à opinião pública é o grande desafio que, como linha tênue, estendese frágil em nossa sociedade da transparência. (Soares, p. 7)

Esquecimento é poder lutar contra a própria memória na mesma medida que é insurgirse contra a memória compulsória das tecnologias e das redes contemporâneas.

Se antes, a exemplo, os dados de um indivíduo na internet estavam parcialmente restritos à visão recortada do navegador através dos cookies, hoje as redes sociais podem identificar cada usuário em diversas plataformas através de login e senha, ou mesmo IP, padrão comportamental, tipo de conteúdo, traços sutis que fazem parte do cruzamento e eternização dos dados.

Então, para debater o esquecimento, é mister entender que

A história do homem é a história das tecnologias de arquivamento e recuperação de dados. Da comunicação oral passamos para a invenção da escrita, numa pequena cidade chamada Uruk, na Mesopotâmia, há cerca de 3.500 anos. Daí pulamos, 3 mil anos depois, para as máquinas de reprodução de textos e a leiturização da sociedade, com Gutemberg e seu prelo móvel. O novo corte histórico nos encontra quase 500 anos depois, com a tecnologia digital e seus arquivos de múltiplas utilizações. (London, p. 14)

Assim, este resumo da linha histórica das tecnologias não apenas de arquivamento, mas de memória, pode ajudar a compreender como os saltos tecnológicos estão ocorrendo em períodos cada vez mais curtos, dificultando a percepção clara sobre qual seria a próxima grande barreira nesta área ao mesmo passo em que toca o discurso de Mayer-Schönberger, na medida em que o arquivamento de informações estaria acelerando a inversão de custo da memória e do esquecimento. Por milênios era mais barato esquecer, não lembrar, tanto em termos comerciais como em esforço, do que lembrar, já que o acesso às estruturas de 
armazenamento de dados e ao conhecimento para sua utilização eram dificultosos, hoje esta matriz teria se invertido.

Desta forma, se tornou papel do indivíduo não mais se esforçar para lembrar de algo, mas aplicar tempo para escolher aquilo que pretende esquecer.

O problema é que "puxar" conteúdo dá bastante trabalho. Precisamos estar sempre atentos, administrando a nossa própria experiência midiática. [...] à medida que os filtros personalizados ficarem cada vez melhores, a quantidade de energia que dedicaremos a escolher aquilo a que queremos assistir vai diminuir mais e mais. $\mathrm{E}$ além de modificar a nossa experiência com as notícias, a personalização também altera a economia que determina quais matérias são produzidas. (Pariser, p. 64-65)

Em sua obra "Delete", Mayer-Schönberger coloca lado a lado os dois pontos, armazenamento e esquecimento, e argumenta que nos dias atuais, com tantos dispositivos de coleta de dados, imagens, textos, ações, está mais dispendioso aplicar 2 segundos por foto do que guardar todas sem distinção.

O investimento para armazenar milhares de arquivos passa a ser menor do que ter que usar o tempo necessário para selecionar quais de fato podem ser úteis e quais poderiam ser descartados.

Para o autor, como pontuado anteriormente, este seria o primeiro momento da história onde há a inversão do custo de memória e custo do esquecimento.

A memória de cada detalhe foi sendo barateada e o custo para exercer uma curadoria sobre todo o conteúdo produzido por vários dispositivos acoplados à vida cotidiana foi elevado, como sua máxima expressão e extensão exemplificada pelos smartphones, dispositivos computacionais de comunicação, coleta e transferência de dados.

Quando há a inversão entre esquecimento e memória, há também uma inflexão do sujeito e de sua conduta.

If we had to worry that any information about us would be remembered for longer than we live, would we still express our views on matters of trivial gossip, share personal experiences, make various political comments, or would we self-censor? The chilling effect of perfect memory alters our behavior. (Mayer-Schönberger, p.5)

Ou seja, o panóptico de Foucault está não mais em uma estrutura física espelhada, mas na vigilância espelhada nos aparatos infotécnicos que estão acoplados aos indivíduos na cibercultura.

Não é mais a polícia a vigiar o detento, mas a sociedade, os amigos, a família, todos os elos de conexão se tornam vigilantes da conduta cada vez mais explicitada de cada indivíduo. 
É de se questionar se esta autocensura já ocorre de modo majoritário ou se ainda não se tornou prevalente, mas para que sua disseminação ocorre na mesma medida em que o sujeito contemporâneo toma consciência da potencialidade real do uso das redes e de seus dados em favor da microvigilância, seja estatal, seja corporativa, seja no âmbito social.

Mas ainda que se grave a memória, há de se considerar o potencial criativo e de reinterpretação dos sujeito ancorado no que diz Palácios.

[...] como a memória é, por natureza, múltipla, coletiva, plural e individualizada, tantos passados relatados haverá quantos forem os relatos registrados: convergentes, conflitantes, contraditórios, a despeito de toda e qualquer pretensão de objetivismo e imparcialidade [’.]. (Palácios, p. 41)

Alves e Rodrigues ainda se balizarão em Mônica Teresa Mansur Silva para dizer que

[...] em Políticas da Memória e Políticas do Esquecimento, [Maria Letícia Mazzucchi Ferreira] refere-se ao esquecimento como recurso para estabilização de tensões e dissipação do sentimento de vingança utilizado por grupos ou governos, em que o "difícil lema da unidade nacional e do apaziguamento" choca-se com violações a direitos humanos. (Alves, p. 88)

Se o esquecimento estava posto para o apaziguamento, há mais uma inversão pela qual a hiperestesia informacional e dromocrática toma o lugar do esquecimento justamente no aparato de presentificação da memória infotécnica.

Lembrar virou o novo padrão na sociedade contemporânea e o apaziguamento está, com viés, inserido na vigilância sobre aqueles que não cedem à velocidade e ao compartilhamento.

A dromoinaptidão acaba por excluir o que não pode ser lembrado, logo, não pode ser contado ou acessado.

O presente sem passado é uma tela vista com desconfiança ou com, ao menos, certo preconceito por aqueles que se julgam dromoaptos.

Em todo o caso, será necessário sair do vazio jurídico atual, pois uma Web sem regulamentação é uma $W e b$ devastada pelos piores vírus, os das desigualdades, das manipulações e dos mitos. Então se está longe de uma Net que favoreça uma nova utopia de uma sociedade voltada para a troca e a abertura com o outro, desprendida de poderes. Ao contrário, se está diante de um sistema de informação integrada, cuja finalidade está mais para uma economia global do que para um aperfeiçoamento das relações interpessoais... (Wolton, p. 99)

Até o momento, deixada à própria sorte, a internet, e como tal, a rede tem sido trabalhada para recondicionar a lógica de controle ou, ao menos, de hegemonias. Wolton indica a necessidade de preencher a lacuna jurídica, mas o chamado é para que a percepção coletiva possa encontrar nesta lacuna a evidência de que este tema precisa ser melhor compreendido. 
Ao apontar a dicotomia entre uma memória forte e centralizada (que pode ser a metáfora para as redes convergentes de bancos de dados) e uma memória distribuída (como no caso inicial da rede rizomática que viria a ser a internet), Wertsch traz a seguinte avaliação,

Another opposition that defines the conceptual space surrounding notions of collective remembering involves a distinction between "strong," as opposed to "distributed" versions of collective remembering (Wertsch). Strong versions commit the error that the social psychologist Frederic Bartlett (1932) pointed out by focusing on memory of the group rather than restricting themselves to memory in the group. He argued that the former presupposes some sort of collective mind or consciousness above and beyond the minds of the individuals in a group, which is in his view a category error. At the same time, however, the study of memory in the group remains as a legitimate enterprise, begging the question of just how to do it. (Wertsch, p. 89 - 90)

A memória, nesta medida, está em disputa pela centralização do discurso e pela reconstrução da memória baseada em diversos pontos distribuídos. Lembrar ou esquecer o "fato" pode ser algo centralizado, como na versão de Orwell, ou pode ser algo reconstruído a despeito da mídia majoritária.

Considere-se, então, dois desdobramentos com base no trecho acima.

O primeiro trata da questão da memória de um grupo e a memória individual, e dos momentos em que uma ou outra falha. Este "erro", muitas vezes temido, faz parte dos relacionamentos e discursos humanos. Eliminá-lo é, na mesma medida, eliminar o olhar subjetivo. Esquecer está na base milenar do ser humano.

Por outro lado, o segundo olhar possível, fazendo um paralelo com a memória em rede, é possível perceber que o ambiente virtual, a rede pode contrapor o discurso televisivo ou jornalístico das grandes corporações através da reconstrução da narrativa sobre os "fatos".

Esta visão se liga aos pontos potencialmente positivos da rede e da internet, mas o seu contraponto ainda tem peso relevante.

Ainda que o grupo possa fazer emergir um novo discurso sobre os fatos, o alcance das versões "secundárias" das notícias ainda é incomparável com a penetração dos meios de comunicação de massa e sua univocidade.

As vozes múltiplas carecem, ainda, da penetração e, vale citar, da credibilidade que os meios de comunicação de massa possuem frente às massas.

Em um comparativo pouco ortodoxo, é como dizer que o poder de contra-vigilância social frente às grandes empresas de comunicação fosse capaz de derrubá-las, conquanto por ora gera discursos descoordenados e conquista algumas erratas. 
Claro, há os casos nos quais a rede foi parte importante em revoluções contemporâneas.

O que se objetiva nestas linhas não é desqualificá-la, mas apenas destacar que a despeito de seu potencial, a praxis ainda mantém o predomínio discursivo nas mãos de poucas empresas, incluindo o Facebook, que apesar de não ser costumeiramente comparado aos conglomerados midiáticos, hoje é um dos grandes curadores, de modo (alegadamente) indireto, da notícia e do "espaço" "público".

Note-se a separação do "espaço", remetendo ao debate necessário sobre que espaço se constitui nas redes sociais, além de qual tempo está apresentado em seus domínios, do termo "público", que está em berlinda similar, a se responder tanto que características públicas estão integradas a este espaço quanto que público está se formando em relação a ambos.

Então, para tratar de direito ao esquecimento neste cenário, foi necessário caminhar por mais degraus do que a mera verificação do que seria esquecer, já que o esquecimento por séculos foi combatido, mas nos dias atuais amarga sua inflexão.

\subsection{ESQUECIMENTO E MEMÓRIA DA LEI E DOS DADOS}

Aquilo que se encontra de modo mais comum referente ao Direito ao Esquecimento está, geralmente, atrelado, na bibliografia jurídica, aos princípios fundamentais da dignidade da pessoa humana através do art. $1^{\circ}$, III da Constituição brasileira. Segundo Fiorillo (apud Paesani), nossa Carta Magna mais recente mostra explicitamente sua característica antropocêntrica, ao que o autor exemplifica com a relação direta entre direito ambiental e seus reflexos objetivados no bem-estar e na vida humana.

\footnotetext{
Neste contexto, o meio ambiente cultural compreende as inovações tecnológicas e as formas de receber, formar e transmitir conhecimentos que caracterizam a sociedade da informação, bem como os direitos e deveres decorrentes do meio ambiente digital. A velocidade e necessidade de se obter informações para se inserir e atuar na vida social, é de extrema importância para todos os indivíduos do século XXI. Fica claro que neste contexto, a dificuldade em se buscar a veracidade das informações é evidente e preocupante, bem como a necessidade do Direito regular as relações nesse ambiente digital, para que este seja fonte de relações econômicas, políticas, sociais e culturais. (Gomes, p. 88)
}

Assim, o direito positivado, ou seja, inscrito no texto jurídico, vem à baila para equilibrar os interesses e conduzir a vida em sociedade tendo em seu centro o homem como estrutura basal.

Uma das primeiras menções ao direito ao esquecimento em textos legislativos figura na lei francesa de 6 de Janeiro de 1978, relativa à informática, aos arquivos e às liberdades, que prevê em seu artigo $\mathrm{n}^{\circ}$ 40: Toda pessoa física justificante de sua 
identidade pode exigir do responsável pelo tratamento de dados que as informações pessoais que lhe concernem sejam retificadas, completadas, atualizadas ou apagadas [....] logo elas sejam inexatas, incompletas, equivocadas, desatualizadas, ou cuja coleta, utilização, comunicação ou conservação seja proibida. (Commission Nationale de L'Informatique Et Des Libertes, 1978)

Mas esta é a forma como o direito ao esquecimento se apresenta frente a alguns desafios da trazidos pela informática.

Desta forma, como citado há pouco, o direito ambiental passa a ser fator a ser estudado, na medida em que está inscrito também dentro do âmbito da dignidade da pessoa humana, ao que se pode perceber no trecho integral da Constituição Federal do Brasil de 1988, o que amplia o escopo do que vem a ser o esquecimento legal.

Art. $3^{\circ}$ Para os fins previstos nesta Lei entende-se por:

I - meio ambiente, o conjunto de condições, leis, influências e interações de ordem física, química e biológica, que permite, abriga e rege a vida em todas as suas formas."

Para Fiorillo, o tema tem um apelo diferenciado. Segundo o autor,

A Carta Magna de 1988 buscou tutelar não só o meio ambiente natural, mas principalmente em face do que estabelece o art. $1^{\circ}$, III, também o patrimônio genético, o meio ambiente artificial, o meio ambiente do trabalho e principalmente, em face da já citada premissa antropológico-cultural, o meio ambiente cultural. Com isso, conclui-se que a definição jurídica de meio ambiente é ampla, devendo-se observar que o legislador optou por trazer um conceito jurídico indeterminado, a fim de criar um espaço positivo de incidência da norma. (Fiorillo apud Paesani, p. 5)

Este é um ponto relevante do trabalho de Fiorillo, no qual ele aponta para uma característica importante que é a possibilidade aberta e múltipla de entender o meio ambiente como estrutura complexa que está intimamente ligada à vida humana. Assim, conquanto o meio ambiente, nos termos legais, permite abarcar não apenas o meio ambiente ecológico, como possivelmente se pense, mas também o patrimônio genético, como forma constitutiva da vida em sociedade a partir do patrimônio informacional dos genes humanos, da mesma forma, meio ambiente estaria a abarcar questões complexas como o ambiente virtual não apenas pela sua característica de espaço de trocas, mas também por seu aspecto informacional.

$\mathrm{Na}$ medida em que os genes são o composto orgânico da informação de construção biofisiológica de cada indivíduo, ainda que produzidas e replicadas de modo alheio à racionalidade do indivíduo que se perpetua em seus genes e por suas células, a questão vai além, englobando o debate sobre as informações produzidas, consciente ou inconscientemente por cada indivíduo social, compartilhara por opção ou involuntariamente, nas redes de dados. 
Passaria, então, a ser também objeto do direito ambiental as questões pertinentes à esfera digital na medida em que esta além de não se dissociar plenamente do dito "mundo real" também é espaço de trocas e de informações.

Integra-se aqui, então, no ecossistema que dá condições à vida humana o ciberespaço e a cibercultura.

Assim, quando o autor ressalta que "não se pode perder de vista que o direito ambiental tem como objeto maior tutelar a vida saudável da pessoa humana" (Fiorillo apud Paesani, p. 5), está a destacar que na medida em que este valor esteja em risco, é sob a esfera do direito ambiental que pode se enquadrar a lide.

Tanto a materialidade não é o único lastro do direito ambiental, como se poderia supor ao seguir no viés de um pretenso direito restrito às questões de fauna ou flora, que o artigo 216 da constituição acaba por especificar o que viria a ser o patrimônio cultural que está abrangido pelo direito ambiental.

Art. 216. Constituem patrimônio cultural brasileiro os bens de natureza material e imaterial, tomados individualmente ou em conjunto, portadores de referências à identidade, à ação, à memória dos diferentes grupos formadores da sociedade brasileira, nos quais se incluem:

I - as formas de expressão;

LL - os modos de criar, fazer e viver;

III - as criações científicas, artísticas e tecnológicas;

IV - as obras, objetos, documentos, edificações e demais espaços destinados às manifestações artístico-culturais;

$\mathrm{V}$ - os conjuntos urbanos e sítios de valor histórico, paisagístico, artístico, arqueológico, paleontológico, ecológico e científico.

Desta forma, se o patrimônio cultural engloba os modos de criar, fazer e viver, e se estamos conectados durante grande parte do nosso dia, então claramente a internet e os dispositivos comunicacionais, tanto dos meios de comunicação de massas quanto a era digital, fazem parte desta estrutura. Ainda para Fiorillo,

[...] a Constituição não faz restrição a qualquer tipo de bem, de modo que podem ser materiais ou imateriais, singulares ou coletivos, móveis ou imóveis. Além disso, são passíveis de proteção, independentemente do fato de terem sido criados por intervenção humana. Para que um bem seja considerado como patrimônio histórico, é necessária a existência de nexo vinculante com a identidade, a ação e a memória dos diferentes grupos formadores da sociedade brasileira. (Fiorillo apud Paesani, p. 
Assim, dando um largo passo na interpretação das palavras do autor, se para ser considerado patrimônio histórico, um bem, seja ele material ou imaterial, precisa estar ligado à identidade, ação e memória sociais, então, de certa forma, os algoritmos passam a se enquadrarem, com o tempo, em bens que poderiam ser tutelados como patrimônio histórico, na medida em que o discurso identitário se dá, em alguns casos a largo, por meio das redes sociais e das estruturas digitais midiáticas.

\begin{abstract}
O conceito de patrimônio cultural definido pelo art. $1^{\circ}$ do Decreto-Lei n. 25/37 determina que patrimônio histórico e artístico cultural é o conjunto dos bens móveis e imóveis existentes no País, cuja conservação seja de interesse público. O que segundo os incisos I e II do art. 216 da Constituição Federal, inclui as formas de expressão e os modos de criar, fazer e viver. Todo bem referente à nossa cultura, identidade e memória, uma vez reconhecido como patrimônio cultural, integra a categoria de bem ambiental e, portanto, difuso. Isto significa que pertence a todos, o que inclui as futuras gerações (art.225 CF). O patrimônio histórico necessita da existência de nexo vinculante com a identidade, ação e a memória dos grupos formadores da sociedade brasileira. (Gomes, p. 89, grifo nosso)
\end{abstract}

Este pode ser um ponto controverso. Se o direito ambiental vai salvaguardar aquilo que faz parte do patrimônio histórico da humanidade, em qual nível se dará a classificação de tais algoritmos? Esta pergunta se torna pertinente na medida em que o código do Facebook, atua sobre a visão de mundo de bilhões de pessoas, mas ao mesmo tempo está protegido com códigos legais da ordem dos direitos autorais e dos segredos comerciais.

Quem, então, tutela o encaminhamento dos algoritmos com impactos sociais? O direito comercial/contratual ou o direito ambiental? Esta pergunta, por ora, segue respondida não diretamente mas sim pela prática jurídica, que tem privilegiado os aspectos mercadológicos, protegendo o produto "intangível” das empresas de dados e conexão social.

Seguindo o encadeamento, na mesma medida, a comunicação entendida como uma ação está, também, permeada e permeante às tecnologias e internet. Por fim, chegando mais próximo do tema em tela, se há de ser parte da memória aquilo que está apto a tornar-se bem tutelado pelo Estado como patrimônio histórico, estaria a sociedade em sua versão mais acentuada do patrimonialismo histórico.

É preciso aumentar o foco neste item para que ele se preste ao raciocínio proposto.

Ainda que a crise das grandes narrativas tenha sido dada por morta, a história, ou o "histórico" está posto como parte de um passado que é constituinte do presente, questão que se mostra mais do que pertinente ao tema debatido, na medida em que o passado dos últimos anos está mais presente hoje, condensado, do que se pode constatar dias após sua existência. 
Os anos trataram de qualificar os dados e aglutinar a versão mais concentrada da história de muitos indivíduos em pacotes de dados recursiva e recorrentemente disponíveis em um presente perpétuo.

Já o "patrimônio" do binômio patrimônio cultural estaria, de certa forma, respaldado pelo pertencimento, pela propriedade de algo com valor cultural que, antes de tudo, pertence a alguém, mesmo que seja um coletivo, mas que se liga à vida humana, característica evidenciada pela tutela jurídica positivada.

Assim, a posse, a propriedade, a permanência, a manutenção, está a ser produzida e fortalecida em bancos de dados que não são claros, sequer acessíveis aos sujeitos que produzem informações.

O patrimônio, como forma de deter direitos sobre algo, cresce na medida em que a história se alarga em volume e se comprime em tempo, fazendo gravitar sobre a curva espaçotemporal os corpos e mentes daqueles que se dizem autônomos e conscientes.

Usar humanos permeados por estruturas de controle já é algo que estava presente na obra de Wiener mesmo que de forma embrionária. Há, então, que se questionar a cegueira majoritária sobre os efeitos das estruturas de dados sobre os sujeitos. A violência sutilizada que Trivinho sempre destaca estaria, de certo modo, presente desde os primórdios da aceleração, e hoje aprimorada, levando o indivíduo à ilusão da consciência e ao engodo da ação.

Que se fale, então, do patrimônio (particular e governamental) histórico (de algoritmos) considerando o seu impacto na sociedade e em cada indivíduo. Se restar dúvidas do que viria a ser a tutela legal no âmbito digital inserida no direito ambiental, vale uma vez mais requisitar as palavras do jurista.

Como vimos, o direito difuso é aquele que se encontra difundido pela coletividade, pertencendo a todos e a ninguém ao mesmo tempo. Os coletivos, por sua vez, possuem como traço característico a determinabilidade dos seus titulares. Deve-se observar que, ainda que num primeiro momento não seja possível determinar todos os titulares, por conta da natureza do direito coletivo, esses titulares (que estão ligados por uma relação jurídica entre si ou com a parte contrária) são identificáveis. (Fiorillo apud Paesani, p. 16)

Este trecho vem a colocar sob a luz do direito alguns embates, novamente trazendo para o escopo proposto. 
O primeiro, destacando que tipo de patrimônio histórico pode ser constituído a partir da era dos algoritmos, e o segundo, que se dá entre as leis que positivam alguns direitos de liberdade de imprensa e outras que garantem a privacidade e o sigilo do lar.

O direito, então, tutelando o ambiente de dados e o ciberespaço não está restrito por limites eletrônicos, mas também possui suas peculiaridades. O meio ambiente digital, por via de consequência, fixa no âmbito de nosso direito
positivo os deveres, direitos, obrigações e regime de responsabilidades inerentes à
manifestação de pensamento, criação, expressão e informação realizados pela pessoa
humana com a ajuda de computadores (arts. 220 da Constituição Federal), dentro do
pleno exercício dos direitos culturais assegurados a brasileiros e estrangeiros
residentes no país (arts. 215 e $5^{\circ}$ da CF) orientado pelos princípios fundamentais da
Constituição Federal (arts. $1^{\circ}$ a $4^{\circ}$ da CF). (Fiorillo apud Paesani, p. 17-22)

É importante relembrar que o que ficou conhecido como Lei Carolina Dieckmann (Lei n 12.737 , sancionada em 2012 após o escândalo midiático da revelação de fotos íntimas retiradas do computador pessoal da atriz supracitada, trata do crime de invasão de dispositivo informático, no qual há o animus movendi de extrair tais dados, mas pouco fala da falta de segurança dos sistemas tecnológicos para preservar os dados pessoais, ou mesmo das estruturas em rede e dos bancos de dados virtuais e da cloud computing como responsáveis pelo armazenamento adequado de informações sigilosas.

Isso mostra como em alguns momentos o parlamento está focado em resolver e debater questões pontuais mas pouco se aprofunda, mesmo durante as discussões sobre o marco civil da internet, nos itens mais relevantes sobre a cultura e a sociedade nos tempos atuais.

Enquanto o Brasil ainda engatinha em termos de compreensão e clareza pública a cerca da invasão e evasão da privacidade nos dias atuais, a Europa segue com embates acalorados sobre o assunto.

No âmbito da União Europeia, nasceu um modelo diverso de tratamento de dados
pessoais. Esse modelo parte da transposição dos ordenamentos nacionais e
reconhece a autodeterminação informativa que atribui a cada pessoa o poder de
impedir determinados usos das próprias informações. O elemento-chave desse
modelo é o consentimento do interessado. Mas esse modelo europeu está vinculado
ao princípio da finalidade, que prevê casos de indisponibilidade, ou seja, situações
nas quais nem mesmo o interessado pode dar o seu consentimento a determinados
usos dos seus dados. [...] A proteção dos dados pessoais torna-se um valor em si,
um direito fundamental autônomo. (Paesani, p. 24-25)

Algo similar pode ser avaliado na legislação brasileira que permite ao indivíduo ceder os direitos de uso de imagem de modo parcial, mas considerar este um bem inalienável.

Percebe-se, então, que o Estado está buscando compreender em que medida o sujeito é pessoa capaz de alienar-se de algo que outrora não se consideraria. Seus dados pessoais. 
Assim, contratos menores perdem valor se avançarem nos bens indisponíveis. Desta forma, o genoma de um indivíduo poderia ser considerado um bem inalienável no Brasil, porém claramente já não o é no Kuwait, que há questão de poucos dias colocou em vigor uma lei que obriga todos os seus cidadãos a realizarem a coleta de DNA para compor o banco de dados do governo ${ }^{21}$. Se no Brasil o DNA do indivíduo e mesmo de sua fauna e flora são protegidos pela lei, da mesma forma estes mesmos indivíduos terão suas informações digitais, ou ao menos parte delas, protegidas pela Carta Magna?

Eis um ponto relevante. O debate ainda está aberto. Qual é o limite que poderia esclarecer quais informações pessoais são disponíveis para a troca ou mesmo venda e quais são aquelas indisponíveis?

Esta mesma dúvida estava entre os fatores que levaram o público europeu a responder negativamente às comunicações do Google sobre o possível lançamento em 2014 do que ficou conhecido como Google Glass, um óculos munido de computador de bordo, câmera fotográfica, prisma projetor de imagem para o nervo ótico e conexão com a internet.

De todas estas características, o que mais chamou a atenção dos opositores deste produto foi a câmera frontal que poderia a qualquer momento transmitir imagens das pessoas sem seu consentimento. Mas não apenas o público do velho continente se manteve receoso.

Um exemplo prático foi a proibição, no início de 2014, de entrada de pessoas com o Google Glass em dois bares de São Francisco ${ }^{22}$. Um dos bares chegou a publicar a justificativa de que a proibição se deu pois seus consumidores estariam expressando suas preocupações em serem gravados enquanto se divertem ${ }^{23}$.

Mas se o dono do bar toma para si a prerrogativa de impedir quem usa este tipo de dispositivo antes mesmo do Estado, está aí dado um descompasso entre o ritmo das transformações tecnológicas e sociais quando comparado ao processo de atualização legal.

Se o sistema legal sempre teve um certo descompasso entre as inovações e sua previsão jurídica, a dromocracia cibercultural acentuou esta diferença. Entre os galopes tecnológicos e os rodopios legislativos, não se pode dizer sequer que o cidadão exerceu, caso fosse brasileiro

\footnotetext{
21 Kuwait é primeiro país a implementar teste de DNA obrigatório para todo habitante. Disponível em: <http://gizmodo.uol.com.br/kuwait-teste-de-dna-obrigatorio/>. Acessado em 8 de julho de 2015.

22 San Francisco bar bans Google Glass for fear of secret recordings. Disponível em <articles.latimes.com/2014/mar/04/local/la-me-ln-bar-bans-google-glass-wearers-20140304>. Acesso em2 de fevereiro de 2015.

23 Have expressed concerns with being recorded while enjoying themselves. Disponível em <http://articles.latimes.com/2014/mar/04/local/la-me-ln-bar-bans-google-glass-wearers-20140304>. Acesso em 5 de abril de 2015.
} 
este caso, a auto tutela do direito, já que não há positivação desta norma. Quando no Brasil, esta restrição poderia talvez ensejar ação na justiça por discriminação, haja vista que o cidadão não está legalmente proibido de trajar qualquer dispositivo computacional vestível e na medida que este tipo de recinto está caracterizado como público.

Outro ponto relevante, que traz indícios da jovialidade tanto todo tema quanto da compreensão social de seus impactos é que ao proibir o acesso de pessoas que trajem um óculos inteligente, espera-se reconquistar a zona de liberdade discursiva que a tecnologia estaria deturpando apenas com o pensamento da vigilância, mas esta mesma vigilância pode ser ainda mais eficiente, nos dias atuais, não com as imagens panorâmicas de uma câmera de óculos, mas nos dados detalhados de cada celular conectado à internet.

Mas se ainda assim o problema persistir por conta da câmera, este mesmo problema se daria contra os celulares em mesma medida.

Resta, então, acreditar que a reação fora tomada contra não a gravação, ou mesmo a transmissão, mas a dificuldade de coletar indícios desta prática, ou seja, o transmissor estaria camuflado enquanto repassa vídeos e fotos sem o consentimento dos copresentes.

Destaque-se, então, quando citou-se a violência sutilizada da dromoaptidão cibercultural, era este ponto que se objetivava. A repulsa não foi pela gravação mas pela evidência escancarada da incapacidade dos indivíduos de evitarem serem monitorados. $\mathrm{O}$ celular, que oferece ainda mais recursos para tanto, não fora rechaçado, persistindo sua vigilância de modo camuflado, ainda mais em um cenário que, como Dorothy Glancy indica, “as pessoas estão sendo levadas a ceder muita informação e talvez seja hora de alguém perguntar o que achamos.” (apud Paesani, p. 30)

Estamos autorizados a passar dados pela internet, por dispositivos conectados à rede, e as empresas estão autorizadas legalmente a coletá-los. Mas ainda que estejam autorizadas, seguem desobrigadas a comunicar claramente a coleta e seus fins.

A exemplo, um acesso rápido ao UOL, quinto site mais acessado do Brasil, atrás apenas do Google (nacional e internacional), Facebook e Youtube ${ }^{24}$, tornará o usuário comum visível para nada menos do que outros 22 bancos de dados, estando entre eles as seguintes plataformas: Admotion, Adometry, Androit Digital Solutions, AppNexus, ChartBeat, DataXu,

\footnotetext{
${ }^{24}$ Quais são os sites mais visitados do Brasil em 2014?. Disponível em:

<http://www.conectei.com.br/internet/lista-sites-mais-visitados-brasil>. Acesso em 2 de fevereiro de 2015.
} 
DoubleClick, DynAd, Exactag, Facebook, MediaMath, Melt, Netmining, Rubicon, entre outras.

E a oferta de dados não se restringe a sites comerciais. O site www.brasil.gov.br, do governo federal, dispara 8 marcadores de empresas de dados, e o site do Governo do Estado de São Paulo dispara dois marcadores, sendo que um deles é usado exatamente para mídia publicitária. Por fim, o site da Universidade de São Paulo dispara apenas um marcador de dados de empresa externa.

Ao retomar a questão legal,

Sem a presença de uma tutela significativa em relação ao conjunto de informações recolhidas a nosso respeito pelas inovações tecnológicas dos sistemas inteligentes, torna-se difícil preservar a privacidade e a dignidade sem reduzi-las a "mercadorias". Como consequência, sente-se a necessidade de eliminar a ingerência de elementos externos na esfera privada das pessoas. (Paesani, p. 31)

É preciso, então, tutelar, ou seja, colocar sob os auspícios da lei tal coleta e tratamento de dados para que haja a preservação da privacidade e dignidade humanas, a serem, então, protegidas inclusive frente ao Estado, que ao vigiar toda a população a priori pode estar deteriorando a presunção da inocência. Se o volume de empresas que coleta dados no UOL pode parecer pequena, basta considerar que cada empresa pode dar usos diversos para cada informação coletada. Além disso, um exemplo que vêm dos Estados Unidos mostra o quão profunda pode ser a classificação de dados oriundos tanto da internet quanto de outras bases de dados.

[...] a Acxio sabia mais sobre onze dos dezenove sequestradores [dos aviões de 11 de setembro] do que todo o governo dos Estados Unidos - inclusive seus endereços antigos e atuais e os nomes das pessoas com quem moravam. [...] vejam só o que a Acxion sabe sobre $96 \%$ dos domicílios americanos e meio bilhão de pessoas em todo o mundo: os nomes de seus familiares, seus endereços atuais e antigos, a frequência com que pagam suas contas do cartão de crédito, se tem um cachorro ou gato (e de que raça), se são canhotos ou destros, que remédios usam (com base em registros de farmácias)... A lista de dados tem aproximadamente 1.500 itens. (Pariser, p. 43)

Com tantas categorias de dados disponíveis, que privacidade pode ser preservada?

Sem a tutela dos Estados, ou mesmo sem uma tutela legal internacional que possa atuar para proteger a identidade dos indivíduos, considerando que não se está tratando, neste momento, apenas das formas de invasão e evasão da privacidade na internet, mas de modo geral, o indivíduo seguirá sendo catalogado e classificado sem que haja dispositivos contundentes para que retome a dianteira sobre o seu passado-presente.

Catalogar os indivíduos sem dar visibilidade a eles sobre quais dados estão sendo considerados, e sem oferecer outro entregável de valor similar, é estabelecer uma relação de 
desequilíbrio entre os indivíduos e as organizações e governos que utilizam estes dados de modo sigiloso ou ao menos pouco evidente.

A manipulação do público - buscada e conseguida pela indústria cultural, entendida como forma de domínio das sociedades altamente desenvolvidas - passa, portanto, no meio televisivo mediante efeitos que se realizam nos níveis latentes das mensagens. Estas fingem dizer uma coisa e, em vez dela, dizem outra; fingem ser frívolas e, no entanto, ao se colocarem além do conhecimento do público, reforçam seu estado de dependência. O espectador, mediante o material que observa, é continuamente colocado na condição de assimilar ordens, prescrições e proscrições sem saber. (Wolf, p. 82-83)

É neste contexto que, se nascido em outros campos, o direito ao esquecimento precisa se fazer presente também na seara digital. A captura indiscriminada e pouco clara de dados na internet, bem como seu cruzamento através de negociações das quais poucos usuários chegam a tomar conhecimento colocam em cheque o alto conhecimento que muitas empresas possuem de cada cidadão, de modo desigual. Frente a elas, o próprio Estado está menos munido de capital tecnológico, intelectual, procedural e propedêutico para lidar com tamanho volume de informações.

Na medida em que não é combatido, "esse tipo de invasão de privacidade passou a ser bem tolerada, porque se percebeu que os registros podiam ser úteis para intimidar comportamentos indevidos e até para elucidar crimes." (Paesani, p. 30) Mas o direito não está posto para garantir o conforto, mas a justiça e a qualidade de vida da pessoa humana.

Se muitos recorrem ao caminho simplista de condenar as empresas pelas práticas, pecam não por perceber a conduta corporativa, mas por não perceber o imperativo dromocrático cibercultural. A velocidade segue cooptando empresas, governos e, sim, pessoas para replicarem e praticarem a cibercultura.

Um exemplo controverso de embate entre empresa e governo pode ser visto no caso da recusa do Google, a princípio, de entregar, e quando o obrigavam, a recusa em manter sigilo sobre os dados que os governos lhe requisitava. $\mathrm{O}$ conflito pode ser visto como o mercado e o governo ou, como propôs o Google, entre o controle do Estado e a liberdade de expressão e direito à privacidade do indivíduo que usa as redes.

Longe de estar moco à questão econômica e simbólica da liberação ou não dos dados para o Governo, a verdade é que a recusa do Google acabou gerando um problema maior e mais silencioso. Aprovada nas instâncias legais estadunidenses, as cartas de segurança nacional são o dispositivo do governo que forçam, sem precisar de suporte ou aval do judiciário, a entrega de qualquer dado que seja de interesse da segurança americana. 
As cartas de Segurança Nacional (NSL, na sigla em inglês) são intimações judiciais enviadas pelo FBI ao Google que permitem ao FBI obter informações pessoais de cidadãos sem necessidade de envolver a Justiça. Foram autorizadas como medida de combate ao terrorismo e passaram a fazer parte do relatório de transparência da empresa. $\mathrm{O}$ documento requer sigilo do destinatário e o Google pode ser proibido de notificar o usuário sobre sua existência [da carta]. (Paesani, p. 31)

Mas o que as NSL recebem é o dado categorizado, limpo, mas a pressão às empresas é apenas um dos caminhos para obter os dados, já que há aporte legal para que o governo federal dos Estados Unidos possa interceptar e armazenar todos os dados que são trafegados em território nacional. Em outras palavras, considerando que muitos servidores e infovias estão ou passam pelos Estados Unidos, é de se constatar que mesmo as compras de brasileiros no interior do Alagoas podem estar sendo catalogadas e preenchendo bancos de dados, a princípio, da segurança.

Quando Barbosa trata do Discurso da servidão voluntária, resultado de cartas deixadas a um amigo por Étienne de La Boétie, coloca-se a questionar a estrutura do direito. Para Barbosa, há ainda uma zona obscura que não permite traçar os limites ou mesmo indicar até que ponto o direito é uma estrutura de promoção da justiça e do equilíbrio ou um consolidador das estruturas de poder e servidão. "O capitalismo global na sociedade da informação sob a fantasia da celebração da diversidade cultural experimenta nova tendência oligárquica." (Barbosa apud Paesani, p. 64)

A emancipação pretendida pela internet está sendo emparedada por diversos fatores, entre eles, a falta de clareza sobre os limites das condutas nas redes. Da mesma forma, a emancipação social pelos meios de comunicação contemporâneos, e entre eles está, claramente, a internet, estão sendo convertidos paulatinamente em estruturas de vigilância. E ao retomar Bruno, a vigilância pressupõe a interferência, em busca de controle.

Outro modo e avaliar o esquecimento e o impacto do hiato jurídico neste campo pode ser visto de modo metafórico abaixo.

Em nosso caso, percebemos que a regra era simples "Não mates", e que essa regra, como a compreendemos, não admite tais exceções. Isso não significa que matar não seja sob nenhuma circunstância o melhor curso disponível; significa, sim, que mesmo tais assassinatos racionalmente justificáveis violam uma exigência moral e obrigam o ser humano a ter emoções e pensamentos apropriados a uma situação de violação. (Nussbaum, p. 41)

Nos termos deste estudo, violar os dados individuais estaria em questão como uma violação de um valor social? Mas se, na medida em que até mesmo a morte está positivada na lei, o feto gerado pelo estupro, o anencéfalo, ou mesmo alguns criminosos em países como a Indonésia, como o acesso a dados pessoais poderia ser diferente? 
Mas conquanto a morte legalizada, a morte determinada e protegida pelo Estado pode dar cabo do organismo, ainda preserva e tutela os direitos da personalidade e imagem, quando a violação tem sua origem em quem o sujeito é discursivamente, a dinâmica plástica do que se é, foi e será pode ser considerada ainda mais prejudicial do que a própria vida individual em si.

Hoje o Estado permite a morte do anencéfalo e do feto fruto de estupro de modo declarado e positivado em lei. Na mesma medida, o legislativo deixa a mercê o direito ao esquecimento, que por vezes é considerado pelo jurista ou operador do direito mas que ainda não está escrito em lei, logo, não oferece garantias. "[...] there is no objective measure that stays constant over time through which we humans can judge the meaning and value of the words we read, or of the external memories we recall.” (Mayer-Schönberger, p. 35)

Se mesmo salvando os dados, arquivando os artefatos de memória, ainda assim o que se lembrará será o presente do momento de lembrança, não o presente do momento dos fatos.

\subsection{ESQUECIMENTO POSITIVADO}

Como foi colocado brevemente em outro momento, muitas vezes a questão do esquecimento, quando apresentada em termos legais, está muito atrelada ao debate sobre o direito à informação.

Mas antes de descer a este nível, é pertinente resgatar as palavras de MayerSchönberger, para quem parte do vislumbre sobre a dificuldade contemporânea em abandonar artefatos de memória pode comprometer o futuro de pessoas ou mesmo grupos, que serão privados de uma segunda chance.

Para ele, "for centuries, moving from one community to another permitted people to restart their lives with a clean slate, as information about them stayed local." (MayerSchönberger, p. 99)

Um exemplo claro disso, além do caso de Lilia Rodríguez já citado, onde seu nome foi usado por rivais para indicar que ela teria admitido manter relações sexuais com um homem casado, sendo alegada como soropositiva para o vírus do HIV, apenas para lhe dar uma lição, tem-se também o caso de Mônica Lewinsky, que em uma palestra intitulada "O preço da 
vergonha" ${ }^{25}$, disse acreditar ter sido a primeira grande vítima do julgamento público e imediato, em escala global, vindo dos internautas.

Já o caso de Daniella Cicarelli, iniciado em 19 de setembro de 2006 por conta de um vídeo que mostrava a apresentadora em suposta prática sexual em uma praia ainda não chegou ao seu fim.

Em termos comuns, o esquecimento que seria uma oportunidade de recomeço, em alguns casos recebe contrarrazões quando a vítima da memória infotécnica é uma celebridade. Mas ainda assim, teria um cidadão comum mais ou menos direito a sua privacidade e mesmo ao esquecimento infotécnico do que a Cicarelli ou mesmo a Lewinsky?

Em matéria ${ }^{26}$ publicada no site de notícias UOL, vê-se que mesmo no Brasil o direito ao esquecimento ainda é pouco considerado frente a outros direitos já positivados.

A publicação de biografias não autorizadas foi aprovada, por unanimidade, pelo STF (Supremo Tribunal Federal). Por nove votos a zero, a corte decidiu, na tarde desta quarta-feira (10), em Brasília, que os livros e obras audiovisuais biográficos estão liberados em todo território nacional sem a necessidade de permissão prévia do biografado ou de seus herdeiros.

[...] O consenso entre os ministros que participaram da sessão é de que a exigência é uma forma de censura e vai contra a liberdade de expressão, garantida em Constituição, e que medidas reparadoras para possíveis distorções podem ser discutidas na Justiça. Votaram a favor da publicação sem autorização os ministros Carmem Lúcia, Luís Roberto Barroso, Rosa Maria Weber, Luiz Fux, Dias Toffoli, Gilmar Mendes, Marco Aurélio Mello, Celso de Mello e do presidente da corte, Ricardo Lewandowski. (UOL)

Em outras palavras, o direito à informação, em solo brasileiro, está acima do direito ao esquecimento. Na mesma medida, a justiça dará a oportunidade do indivíduo que se sentir lesado agir legalmente para reparar e cessar o dano, mas não lhe permitirá evitar que a comunicação ocorra.

Assim, a legislação brasileira, bem como os altos operadores do direito, está disposto a colocar em risco o indivíduo por um bem que seria maior, a saber a sociedade, e em seguida reparar parcialmente este dano. Mas usando um dos casos mais conhecidos, a proibição da publicação da biografia não autorizada do cantor Roberto Carlos, a questão que fica como provocação, antes que se dê os próximos passos nesta análise, é se de fato a liberdade de imprensa pode invadir a vida pessoal do cantor ou se deve preservá-la. Na mesma medida, o Estado pode invadir a vida privada de qualquer cidadão e a posteriori ressarci-lo em caso de

\footnotetext{
${ }^{25}$ The price of shame. Disponível em: <https://www.ted.com/talks/monica_lewinsky_the_price_of_shame>. Acesso em 10 de maio de 2015.

${ }^{26}$ Por unanimidade, STF aprova a liberação das biografias não autorizadas. Disponível em: $<$ http://entretenimento.uol.com.br/noticias/redacao/2015/06/10/por-unanimidade-stf-aprova-a-liberacao-dasbiografias-nao-autorizadas.htm>. Acesso em 15 de junho de 2015.
} 
equívoco ou deverá, a princípio, considerar o cidadão livre e inocente até que se prove, como canta o ditado conhecido, o contrário?

Retome-se, então, o encadeamento sobre o direito ao esquecimento, que a exemplo do que se apresentou acima, por vezes conflita com outros direitos positivados, como o caso da liberdade de expressão. Mas ocorre que há dispositivos legais já consolidados que estão focados em permitir que um indivíduo tenha parte de sua vida esquecida, e isso tem origem há muitas décadas, não sendo exclusividade dos debates contemporâneos sobre a cibercultura e a memória em rede.

Isso ocorre por conta de ações em diversos países que buscavam dar garantias de ressocialização para condenados que já tivessem cumprido sua pena.

No Brasil, após cumprir sua pena, o condenado está quite com a justiça e não deve mais ser assediado sobre algo que já está concluso.

Por mais que as consultas a seu nome na justiça não retornem com suas penas, o diário oficial segue como registro, e da mesma forma, a justiça, para fins processuais futuros, mantém todo o histórico.

Em países diversos a questão está atrelada à possibilidade da mídia tratar de qualquer assunto como base da democracia moderna, colocando em polos opostos a liberdade e o esquecimento, quando no futuro justamente a liberdade estará contrastada com a memória.

Soares, por exemplo, indica que

uma das primeiras menções ao direito ao esquecimento em textos legislativos figura na lei francesa de 6 de janeiro de 1978, relativa à informática, aos arquivos e às liberdades, que prevê e, sei artigo $n^{\circ}$ 40: "Toda pessoa física justificante de sua identidade pode exigir do responsável pelo tratamento de dados que as informações pessoais que lhe concernem sejam retificadas, completadas, atualizadas ou apagadas [...] logo elas sejam inexatas, incompletas, equivocadas, desatualizadas, ou cuja coleta, utilização, comunicação ou conservação seja proibida. (Soares, p. 4)

O que seria esquecer em termos jurídicos ou mesmo sociológicos?

De certa forma, há um pensamento corrente que indicar que o esquecimento seria a curadoria natural sobre informações que o organismo, de modo econômico, não estaria disposto a despender energia em sua conservação, opondo-se à memória como a manutenção de uma informação suficientemente relevante a ponto de justificar o gasto energético para mantê-la de certo modo acessível ao sujeito / organismo. "To cope with the sea of stimuli, our brain uses multiple levels of processing and filtering before committing information to long-term memory.” (Mayer-Schönberger, p. 17) 
Há, então, uma questão de eficiência energética e de processamento de informação pelo cérebro, que tendo seus recursos limitados para dar conta de controlar diversas funções como as fisiológicas, sociais e psicológica, precisaria optar por concentrar seus esforços nas informações que possam manter a homeostase, ou seja, o equilíbrio corpóreo, e a perpetuidade do organismo, em si.

Para Soares,

Esquecer é ter a capacidade de descartar da memória aquilo que já não é importante, dando mais espaço para lembranças que são efetivamente relevantes. O direito ao esquecimento está relacionado ao uso e armazenagem de informações pessoais sigilosas (como números de documentos, históricos médicos, profissionais, etc.), mas também toca toda a trajetória de vida do indivíduo - desde antecedentes criminais a questões de relacionamentos íntimos e violências sofridas. (Soares, p. 5)

Se "na Europa, o direito à privacidade está acima da liberdade de expressão; [e se] já nos Estados Unidos, o inverso se aplica" (Soares, p. 7), no Brasil está sobre este debate os direitos fundamentais da dignidade da pessoa humana.

Assim, antes da liberdade de expressão, está a medida antropocêntrica do bem coletivo comparado ao bem individual, na mesma medida que se confrontam os danos coletivos e danos individuais, percebendo a tutela do estado ao elo humano, ao elo de menos força no embate franco, mas que ganha a proteção positivada da justiça constitucional.

Ainda que em outros países o grande debate passe por questões como a falta de relevância pública para fatos no passado, no Brasil, via de regra, este debate não conquista espaço na medida que não está na temporalidade a questão maior para definir o direito em si, mas na dignidade da pessoa humana, independentemente do tempo pretérito, presente ou futuro.

A justiça brasileira estaria, então, voltada para a defesa constante da dignidade daquele que é seu elo menor, mas por seu conjunto, constitutivo, o sujeito brasileiro ou naturalizado.

É impossível apagar fatos passados ou reescrever a própria história. Mas o direito ao esquecimento oferece em nosso tempo a esperança de retomar o curso normal da existência, além de representar uma possibilidade de discutir o uso que é dado aos eventos pretéritos da vida de alguém nos meios de comunicação social, sobretudo nos meios eletrônicos. (Soares, p. 12)

Pode-se, então, perceber como o debate do esquecimento, no âmbito legal, está voltado para o dano vinculado à manifestação ou afloramento de um passado verídico ou verossímil, mas que teve seu lugar histórico datado, ou mesmo do desvirtuamento da verdade dos fatos pretéritos resgatados e ressignificados no presente, porém a mesma autora que traz à baila a questão da possibilidade de apagar ou não o passado ressaltou, em momentos distintos de seu 
artigo, a questão da memória individual utilizando os suportes infotécnicos e também da questão do esquecimento como curadoria sobre a relevância dos dados a serem lembrados.

Assim, o questionamento segue o rumo da avaliação da seara jurídica, mas abandona-se por vezes a visão complexa que o esquecimento está além do simples desejo ou necessidade de ser capaz de reconstruir o presente livre de amarras delituosas ou constrangedoras do passado. Esquecimento, ainda mantendo em vista a questão da memória individual tecnicizada, está amplamente relacionado à polivalência da vida e a sua plasticidade.

A autora do artigo "Internet, memória onipresente - Direito ao Esquecimento versus Direito à informação", publicado nos anais do VIII Simpósio Nacional da ABCiber, dá destaque a uma pesquisa de 2012 da Universidade de Columbia segundo a qual há a ocorrência contemporânea de "um fenômeno curioso: as pessoas estão cada vez mais dependentes das informações disponíveis na Internet. Elas utilizam os motores de busca online como uma espécie de memória externa auxiliar." (Soares, p. 2)

Seu trabalho acaba por indicar que as estruturas de memória externa, e neste caso a internet e os motores de busca, são um "suporte muito eficaz também à memória individual" (Soares, p. 2), ou seja, quando o direito ao esquecimento é tratado, ou melhor, quando o próprio esquecimento é tratado na contemporaneidade, há outro campo a ser considerado que é o arquivamento voluntário ou mesmo o acoplamento de tais estruturas tecnológicas à estrutura de memória individual de tal forma que alguns indivíduos podem acabar relegando os detalhes mais precisos à memória infotécnica e guardando apenas a leve referência para que possa realizar uma busca posterior em caso de necessidade. Sem dúvida, o registro digital é uma nova forma de inscrição do passado que constitui-se em uma mescla de continuidades e rupturas com os sistemas de registros anteriores. (Dodebei, p. 44)

Mas se o sujeito atua para manter os artefatos de memória salvos em uma linguagem ou esfera que possa acessar a posteriori, possui o direito de fazê-lo sobre as informações de terceiros?

O direito está olhando para a coleta de dados ou apenas para sua midiatização?

Muitas vezes as questões de identidade e imagem figuram no cenário jurídico em ações e causas relacionadas a notícias falsas ou escandalosas, indicando o direito a personalidade e à imagem, mas poucas vezes a privacidade é mencionada.

Quando muito, o que se encontra na literatura jurídica é a invasão do espaço privado com lentes telescópicas, mas pouco se mostra dos dados capturados no convívio diário. 
Um exemplo de como muitas vezes a rede pode servir de suporte para referenciar e classificar os indivíduos sem sequer que eles saibam pode ser o aplicativo Lulu, que permite a usuários darem notas a homens com quem supostamente tiveram algum relacionamento ou encontro. O Lulu usa os dados do Facebook para criar as fichas de avaliação, mas não os notifica de que estão sob julgamento.

Então, quantos homens tentaram marcar encontros e foram recusados sem sequer saber que o motivo poderia estar nos dados que falam sobre como eles seriam?

Enquanto em tempos anteriores o ato de lembrar estava atrelado à capacidade de memória individual e o suporte de alguns materiais em diversos formatos, a possibilidade de reunião de praticamente todas as informações em suporte digital faz com que sequer a referência original, ou seja, o contexto, precise ser retida.

Basta um item para que o processo de busca retorne algum conteúdo específico sem que isso necessariamente reavive parte do entorno do instante e do cenário de produção desta informação.

Soares ainda traz as palavras de João Canavilhas, que indica brevemente como estas informações acabam se dispondo nos dias atuais. Para ele, "este manancial de informação representa uma memória social, dinâmica, organizada e navegável." (Canavilhas apud Soares, p.2)

É preciso, então, avaliar cada um dos itens elencados por Canavilhas. Na medida em que as informações passam a ser capturadas e armazenadas e seu acesso se torna facilitado, qualquer informação pode participar de modo atemporal da memória social, mas aqui há de se resgatar as palavras da autora Soares que indicam também a participação deste ecossistema infotécnico também sobre a ecologia mnemônica no âmbito individual; seu caráter dinâmico pode relacionar-se tanto à quantidade de informações novas que as estruturas infotécnicas recebem diariamente quanto à qualidade das informações e novos dispositivos de coleta de dados sendo integrados aos atuais.

Outra característica deste dinamismo pode inclusive ser alegada sobre a reedição de parte do passado-presente em silos de informação, na medida em que o dado é flexível, sua edição pode criar novas formas de compreender a informação; ao referenciar a informação contemporânea também como organizada, o aspecto de classificação e cálculo mostra suas características de agrupamento e extrapolação de dados, ou seja, na medida em que as informações que outrora se perdiam agora estão não apenas armazenadas, mas de certa forma 
tiveram sua estrutura de busca facilitada, o que antes seria custoso agora se torna parte do instante contínuo de cada indivíduo; por fim, atrelado a todos os itens anteriores, o aspecto da navegabilidade da informação está posto para ressaltar que os ambientes informacionais se tornaram lisos, deslizantes.

A informação ubíqua e hiperconectada assume agora aspectos quiméricos pela navegação não linear, possibilitando a bricolagem de tempos distintos em uma mesma fotografia informativa sobre um passado-presente pesquisado, ainda mais em tempos de datificação ${ }^{27}$, que Fava (2014) vai resumir como sendo a possibilidade de tornar tudo quantificável, como já tratado anteriormente.

Isso ocorre também, como indica Soares, por conta da permeabilidade das estruturas de dados. As palavras exatas trazem que "nessa era da informação onipresente, já não há memória que se esconda - sigilosa é apenas a memória nunca revelada." (Soares, p. 3)

Deste modo, pensar o campo do esquecimento não é apenas refletir sobre o revelado, mas também sobre o oculto, que pode, inclusive, fruto da coerção social exercida através das pessoas inseridas na cibercultura. Para Lazarsfeld-Merton, “[...] o impulso que leva ao conformismo e é exercitado pelos meios de comunicação de massa deriva não apenas do que é dito, mas sobretudo do que é ocultado.” (Lazarsfeld-Merton apud Wolf, p. 58)

A ausência da positivação explícita do direito ao esquecimento deixa desprotegido o indivíduo, o cidadão comum, mas permite o ocultamento da redes de coleta, tratamento e categorização dos dados, da vigilância ao comércio de informações privadas, que com a visão contratualista pode até estar coberta e garantida legalmente por um clique em opt-in, mas que não sustenta uma visão mais aprofundada de como estes dados podem assediar o indivíduo por muito tempo mais.

Então ainda que o tema do direito ao esquecimento esteja em pauta, esquecer, apagar é também construir a narrativa que levará a condutas diferentes daquelas tidas em cenários onde este aparato tecnológico não estivesse presente.

Alves e Rodrigues ao comentar sobre o reconhecimento do direito ao esquecimento pela Corte de Justiça da União Europeia, que

[...] a decisão ao analisar o pedido formulado de exclusão de dados pessoais na rede face à Diretiva 95/46-CE, concluiu que a liberdade de informação não se pode sobrepor ao direito à privacidade e que a atividade desenvolvida pela Google e sua filial espanhola constitui tratamento de dados e não mera ferramenta tecnológica de

\footnotetext{
${ }^{27}$ Do inglês, datification.
} 
busca. Em sentido oposto, a Ministra Nancy Andrighi se manifestou no sentido de que "não se pode, sob pretexto de dificultar a propagação de conteúdo ilícito ou ofensivo na web reprimir o direito da coletividade à informação". (Alves, p. 87-88)

Agora cabe questionar, neste caso, se a atividade da Google se caracteriza como tratamento de dados, e esta está sujeita aos rigores da lei europeia de direito à privacidade, como estariam classificados os aplicativos de celular ou mesmo as redes sociais.

O legalismo costuma mirar na Google por dizer que não há um termo de aceitação assinado ou marcado pelo usuário ao ter seus dados catalogados pela Google, mas em que medida isso salvaguarda o usuário do Facebook enquanto os termos de uso são alterados constantemente?

Em que medida os governos e as casas legislativas estão se dedicando para garantir que a coleta de dados não está servindo para objetivos alheios aos propósitos alegados?

Os contratos vinculados, ou termos de uso que concedem poderes de distribuição dos dados a terceiros acabam por dar contornos para a lavagem de dados em um mercado negro da informática enquanto os juristas contratualistas ainda se preocupam como o chamado optin.

Dados coletados em um jogo de celular podem alimentar bases de dados no mundo todo. Se a lógica da proteção social frente aos 4 cavaleiros do ciberapocalipse fosse consistente, ao menos haveria o quinto cavaleiro que derrubaria os limites do público e privado, porém, é de se questionar se este quinto cavaleiro está posto para ser combatido ou auxiliado pelos estados nacionais.

Enquanto as estruturas de memória digitais, neste sentido, atreladas aos algoritmos de classificação atuam para definir qual passado será presentificado neste instante, na mesma media estão eles próprios atuando para aquilo que, mesmo que guardado, mesmo que salvo na rede e nos bancos de dados, deverá ser esquecido.

Aquilo, então, que é ocultado está posto como outro fator constitutivo do ecossistema da memória e do esquecimento e da dinâmica comunicacional e identitária.

Esta decisão cara ao indivíduo que se pretende sujeito construtor, ao menos em partes mais consideráveis, de sua própria identidade agora é parte de um sistema infotécnico que pouco dialoga com o indivíduo sobre suas formas de cálculo ou seus valores de classificação, mas que opta por construir o presente representado pelas estruturas midiáticas e tecnológicas. 
questões de deslocamento. Sempre há uma duração em um ato de comunicação. (Wolton, p. 101)

Em um paralelo breve para suavizar os exemplos contemporâneos e retomando a mitologia grega, sem o tempo de Cronos, não há a união com a Reia, a fertilidade. Nada surge se não pela fertilidade unida ao tempo. Deles, juntos, derivam os deuses gregos, e posteriormente os homens e mulheres. Sem o tempo, esvai-se a relação com o próprio espaço.

$\mathrm{O}$ ato de criar, de comunicar, depende do tempo, do tempo criativo e do tempo destruidor. As duas facetas do tempo grego são as duas faces do tempo comunicacional, do tempo que cria e do tempo que esquece, para fazer perecer e surgir outro com base dos despojos e corpos mortos no passado.

O passado é, então, seminal. É matéria orgânica que nutre o presente com o decorrer do tempo. Se este não existir, se a morte do passado não servir de renascimento do presente, a desnutrição do presente o tornará letárgico e moribundo.

Este é um cruzamento pouco ortodoxo da mitologia grega com as estruturas ecológicas da biologia. É sobre o corpo decomposto de plantas e animais que brota, usando os nutrientes putrefatos do que um dia vicejou, as ervas e árvores pujantes. Sem a camada orgânica do presente-passado, vivo-encerrado, não haverá frutos nos galhos ressecados.

Sem o passado em decomposição pelo tempo não há como nutrir um presente para que floresça. Sobre a morte do que foi está a força do que é, formado vivo, formando.

Wolton está a chamar de volta o tempo da morte, o tempo da releitura, o tempo do pensamento. O tempo que permite usar o que foi para construir o agora. As raízes precisam buscar fundo a matéria orgânica da vida. Sem ela, sem as raízes do passado, resta parasitar as estruturas que ainda mantém alguma seiva.

É, este tempo, o tempo do esquecimento que permite o amadurecimento de frutos novos. É o passado esquecido e por vezes relembrado à custa de reconstruções de pedaços antigos e novos que mantém o ecossistema em movimento.

Nesta medida, o direito a não responder de modo ágil, a não ter a resposta rastreada e prevista, a não ser a mesma árvore a dar o mesmo fruto é o direito ao esquecimento, e como tal, o direito a ser alguém autoral no presente.

Entre o que se quer esconder e aquilo que se quer mostrar há um hiato protegido não pelas leis antropocêntricas, mas pela positivação da proteção do patrimônio intelectual e competitivo das empresas, o que pode ser considerado perverso por alguns, mas também do 
próprio Estado através dos seus gatilhos de Poder de Império sobre os assuntos de segurança nacional.

Então aquilo que se esquece não necessariamente é aquilo que é preciso para preservar a vida e para lhe garantir melhores condições futuras, mas é aquilo que serve ao mercado, ao capital.

Ou seja, está sob a égide do medo erigida toda a estrutura de vigilância e conformidade.

O privado agora consiste cada vez mais em um domínio desespacializado de informação e de conteúdo simbólico sobre o qual o indivíduo acredita que deva exercer controle, independente de onde esse indivíduo e onde essa informação possam estar localizados. (Thompson, p. 29)

Este campo de controle está na contraviolência que o indivíduo ensaia executar em uma cultura compulsiva que devora os dados e exige "transparência".

A formação, a deformação do sujeito está sendo recursivamente reforçada por uma necessidade de controle de Estados nacionais, multiplicados por suas estratégias mercadologias, mas todos inseridos, então, e também, na cibercultura, dileta do controle, exímia no escrutínio e dual em seu liberalismo.

O neoliberalismo capitalista agora está refletido no neoliberalismo comunicacional que coloca em disputa econômica os agentes sociais em rede.

Os criadores de programas de xadrez com inteligência artificial aprenderam a
importância do horizonte de soluções do modo mais difícil. Os primeiros programas
treinavam o computador a buscar todas as combinações possíveis de jogadas. Isso
resultava numa explosão de possibilidades, o que fazia com que mesmo os
computadores mais poderosos só conseguissem investigar um número limitado de
jogadas à frente. Os programas só ficaram bons o suficiente para vencer os grandes
mestres de xadrez quando os programadores descobriram uma heurística que
permitia ao computador descartar algumas das jogadas possíveis. Em outras
palavras, era fundamental estreitar o horizonte de soluções. (Pariser, p. 87-88)

Fazendo novamente um paralelo pouco ortodoxo, na mesma medida que a mente artificial colapsava com multiplicidade de possibilidades, a mente humana está posta da mesma forma, pouco capaz de lidar com tanta informação ao mesmo tempo. A capacidade de descartar ou mesmo ignorar, de não dar atenção a uma dada informação é crucial dentro do complexo espectro das relações sociais.

Conquanto cada novo membro de um grupo se torna uma fonte adicional de informações amplas e profundas, se assim o permitirmos, o grau de informação em uma rede de relacionamentos está além das fronteiras atuais de compreensão no detalhe último.

Assim, da mesma forma que é preciso, para a mente biológica ter a capacidade e permissão para deixar de lado algumas (várias) informações, consolidando-as em uma 
amálgama entre memória e esquecimento, e da mesma forma que os computadores mais potentes não deram conta de agir em meio ao excesso de dados sem classificação, é preciso que o complexo mnemônico das redes de dados permita a obsolescência da informação.

Ser lembrado, neste caso, é algo diferente de não ter sido esquecido. Quando a memória passa a ser baseada nas redes de dados, e estas, por sua vez, não permitem a plasticidade da rememoração, não se está debatendo mais o campo do que é lembrado, como algo recriado, mas está no campo do reacontecimento. Aquilo que teria se encerrado e seria lembrado, reconstruído com as rugas do presente será, então, processado também como um acontecimento atual, mesmo que sua data seja pretérita, e as rugas contemporâneas se alisarão sobre a agilidade do tempo presente.

As estruturas infotécnicas de coleta e tratamento de dados estão interligadas e, a esta altura, a questão pode se dar sobre qual a profundidade de dados que já foram coletados e qual a capacidade de traduzi-los em conhecimento (humano) ou produtos (computacionais) objetivos nos dias de hoje.

Para o futuro, em uma visão exponencial, se cada clique e visualização de conteúdo está sendo gravada atualmente, o que será feito dos comportamentos humanos nas próximas décadas?

Enquanto nos tempos das comunicações comportamentalistas havia uma busca de gatilhos fisiológicos para a resposta comportamental desejada, nos dias atuais a hiperestesia não ocorre pelo estímulo escolhido pelo emissor, mas pelos filtros anestésicos constituídos com base nos interesses e comportamento tanto do receptor quanto de uma massa de pessoas similares que ensinam os algoritmos como satisfazer de modo instantâneo e interessantemente fugaz o sujeito conectado às tecnologias de informação e comunicação.

Para Morozov, os intermediários são filtros, são censores em potencial. "The more intermediaries - whether human or corporate - are involved in publishing and disseminating a particular piece of information, the more points of control exist for quietly removing or altering that information.” (Morozov, p. 103)

Quando o direito ao esquecimento é colocado como barreira para o conhecimento público dos "fatos", um dos combates é justamente a ressignificação do passado por filtros e conceitos do presente mas com a possibilidade de atuar sobre dados editados, e ainda, de ao coletar os dados, usar apenas as partes relevantes do conteúdo para seguir enclausurando o perfil algorítmico de cada indivíduo. 
Na medida em que o passado-presente está contido em cada banco de dados e pode, de certa forma, ainda ser editado sem o consentimento ou mesmo conhecimento do indivíduo sobre o qual cada dado se refere, as aflições de 1989 passam a pairar sobre um passado que não morre no tempo do indivíduo, mas que também não necessariamente lhe pertence. Entre Lestásia, Eurásia e Oceania, não se sabe mais quem foi-é aliado e quem foi-é combatente.

O passado parece por isso estar em permanente disputa, onde se questionam cada
vez mais as versões que pareciam assentadas na memória coletiva, quer dos
acontecimentos, quer dos sujeitos históricos representados. Em particular pela
dúvida da veracidade dos fatos, já que o passado está atravessado por constantes
disputas ideológicas e políticas. Pese que existem sempre limites para a sua
manipulação e recreação, pois todo o discurso acerca do passado tem um referente
real: os acontecimentos ou testemunhos históricos (Schwartz). Mas o que importa
realmente tentar perceber, e esse é um dos grandes desafios dos estudos da memória
coletiva, é em que sentido as reconstruções dos acontecimentos históricos tendem a
ser mais um produto do presente do que do próprio passado. (Reis, p. 14)

Construída para não ter começo e nem fim, para estar acessível em todos os lugares, a rede, e posteriormente a internet, atrelada à sua camada de dados, está consumindo informação indiscriminadamente e criando o entorno comunicacional autoreferente de bolhas e filtros.

Ao custo baixo da hospedagem de dados, a priori se coleta todas as informações e $a$ posteriori, ou em tempo real, se processa suas probabilidades e classificações. Parte deste conteúdo ainda é desconsiderado, deixado à margem do processo de cálculo, mas o que não significa que o mesmo é apagado. "Google [...] will no longer keep individualized records forever, but anonymize them after a period of nine months, thereby erasing some of its comprehensive memory.” (Mayer-Schönberger, p.7)

Mesmo anonimizado, ou seja, desprovido de itens-chaves que podem ser usados como informação identificável do indivíduo, a qualquer instante o presente pode consumir este passado para alimentar novos braços quiméricos dos algoritmos da rede através de dados extrapolados ou de cruzamentos mais profundo de bases.

O futuro está morrendo a cada novo dia que se repete sem passado. E este passado é inexistente não por não ter ocorrido, mas por estar disponível em cada instante, a cada acesso à rede, a cada filtro ou busca. O que ocorreu, gravado na memória absoluta, não é passado, é presente. 


\section{CONCLUSÃO}

Ser flexivelmente sensível ao mundo, em lugar de o ser rigidamente, é uma maneira de viver no mundo que permite um montante aceitável de segurança e estabilidade, permitindo ainda, ao mesmo tempo, o reconhecimento da riqueza de valor que há no mundo. (Nussbaum, p.69)

Ao pensar sobre todo o exposto, há de se alegar a possibilidade da ilusão do prognóstico, que poderá provar inverídicas as preocupações dos tecnófobos, como exemplificado abaixo no trecho da obra "A arte de pensar claramente", de Rolf Dobelli.

O professor de Berkeley [Philip Tetlock] avaliou 82.361 previsões de um total de 284 especialistas, compreendidas em um período de dez anos. Os prognósticos dificilmente aconteciam com mais frequência do que se tivessem sido produzidos por um gerador aleatório. (Dobelli, p. 137)

Mas a possibilidade desejada de falha na visão sombria dos desdobramentos da memória em bancos de dados presentificados pelo acesso fácil, ágil e barato, não desmerece todo o trabalho de alerta e de pensamento.

De modo complexo, positivo ou negativo, seja lá qual for o resultado nos próximos anos, será fruto das contingências e ações humanas favoráveis e contrárias à memória infotécnica e tantos outros aspectos da tecnologia contemporânea.

Assim, mesmo havendo falhado em antever os resultados, que seja esta uma bandeira para comprovar a falha, não para reforçar o caminho indesejado.

Na medida em que ainda se chama de redes sociais digitais o que são redes algorítmicas de dados com nós humanos, há de se manter a atenção nos resultados da aceleração cibercultural da sociedade, bem como os imperativos da dromoaptidão.

Relembrando,

[...] a velocidade, longe de vigorar como simples processo social, epifenômeno de fatores concretos que lhe precedem, impõe-se como eixo de organização $e$ modulação de toda a existência social, cultural, política e econômica. Mais que outrora, a velocidade está implicada na reestruturação inteira da civilização contemporânea. (Trivinho, p. 91)

A sociedade participativa, em tempos de extrema aceleração da comunicação e consumo de dados, deverá passar por avaliações profundas sobre qual caminho as sociedades humanas pretendem tomar, não aguardando uma solução técnica emancipatória por si só.

[...] o problema não são os computadores, mas sim o emprego que lhes é dado numa economia cada vez mais caótica, predatória e excludente. Os computadores podem estar se tornando o principal recurso tecnológico concebido pelo homem em termos 
de impacto e relevância sociais, mas, de fato, no capitalismo, estão presos a relações de produção e troca que impedem sua exploração democrática e seu uso com objetivos sociais e espirituais emancipatórios. (Rüdiger, p. 149)

Não só as relações de produção material mas, tanto quanto, as barreiras da dromoaptidão relacionadas à velocidade de interação e resposta aos estímulos ciberculturais podem se constituir como barreiras para o livre uso e apropriação das tecnologias de comunicação para expandir os horizontes humanos através destes aparatos infotécnicos.

Contudo, se "a ubiquidade, a repetitividade e a padronização da indústria cultural fazem da cultura moderna de massa um meio de controle psicológico extraordinário" (Wolf, p. 78), imagina-se ainda como se poderia comparar tal cenário às possibilidades de opressão que as estruturas de dados e memória compulsória podem oferecer.

Estar alheio ou, se consciente mas impotente, frente às estruturas de comunicação que podem ser paulatinamente convertidas em estruturas de vigilância e memória pantópicas pode significar a contribuição para a edificação das estruturas de dado que poderão retornar tanto imediata quanto mediatamente em golfadas de opressão sutilizadas ou, em casos mais extremos, de reforço constante da identidade e história atual e largamente presentificada do cada indivíduo.

Em última análise, a bolha dos filtros pode alterar nossa capacidade de decidir como queremos viver. [...] Talvez pensemos ser os donos do nosso próprio destino, mas a personalização pode nos levar a uma espécie de determinismo informativo, no qual aquilo em que clicamos no passado determina o que veremos a seguir - uma história virtual que estamos fadados a repetir. E com isso ficamos presos numa versão estática, cada vez mais estreita de quem somos - uma repetição infindável de nós mesmos. (Pariser, p. 20)

A resgatar, a questão da bolha de filtros se torna ainda mais relevante ao ter claro como o imperativo dromocrático se apresenta com força de estimular, para não dizer compelir, o indivíduo contemporâneo a desapegar-se ao tempo de reflexão em troca do troféu simbólico da dromoaptidão legitimada pelo fluxo comunicacional espetacular e imagético. $\mathrm{Na}$ comunicação ágil haverá o detrimento da profundidade reflexiva. As respostas espasmódicas podem fazer emergir

A dromocracia cibercultural é, a rigor, um regime transpolítico invisível como a violência da velocidade - erigido no contexto de um regime político tradicional e visível, a democracia (aqui tomada no sentido formal e abstrato, em seu modelo tipicamente estatal, herdado do direito burguês). Nessa perspectiva, a dromocracia cibercultural comparece, em palavras precisas, como um regime eclipsado na dinâmica tecnológica da democracia contemporânea, ou, vice-versa, essa democracia não é, hoje, senão a forma sintomaticamente protuberante da dromocracia cibercultural. (Trivinho, p. 102) 
Permeada e escrutinizada pela cibercultura, a sociedade contemporânea, bem como seu elo mais frágil, o indivíduo, seguem estimulados a acelerar os modos produtivos, o mercado, a economia, as relações de trabalho, amizade, relacionamento.

Por motivos óbvios, a conjunção entre aceleração e excesso é, de fato, mais flagrantemente perceptível no âmbito da própria cultura mediática. Na vigência das redes (de massa e interativas), a produção sígnica diuturna, proveniente de inúmeros pontos de transmissão ao mesmo tempo, culminou, nas últimas décadas do século XX, na formação de uma dromosfera simbólica e imaginária altamente saturada, condição histórica e antropológica inédita em que, segundo Virílio, a "poluição" ruidosa das redes, vale dizer, do tempo real, faz par, ao seu modo, com a poluição sonora e visível da urbis e com a poluição carbônica do meio ambiente. (Trivinho, p. 65-66)

É no tempo real, no tempo destituído do tempo passado e impedido de se preocupar mais com o tempo futuro do que com o tempo agora, que o indivíduo cede seus dados para uma estrutura que está desprovida de maldade ou bondade, de ética ou moral, e que se torna um dos panos de fundo sociais.

Sem um centro, a cibercultura e suas redes não estão dadas ao controle ideológico, dirigido, intencionado e gerido por um único nó ou mente, mas se prestam à pervasividade da vigilância que sorve o resultado da violência sutil da velocidade.

Neste sentido, não se percebe que a escolha a ser feita está em desligar ou não as estruturas técnicas da cibercultura, dado que isso não está sob o controle pleno de um ou outro grupo humano, mas sim como transformar gradativamente a cibercultura e os espaços cíbridos em zonas habitáveis pelo humano.

Naturalmente não há caminho de volta. Nem deveria haver: a internet ainda tem o potencial de ser um meio melhor para a democracia do que a imprensa tradicional, com seus fluxos unidirecionais de informação. Como ressaltou o jornalista A. J. Liebling, a liberdade de imprensa existia apenas para quem tivesse uma prensa. Agora todos nós temos. (Pariser, p. 70)

Ainda haverá alguns grupos de interesses a serem combatidos para que as estruturas infotécnicas de comunicação se tornem mais livres, mas só serão livres na medida em que a sociedade debater e compreender de modo mais aprofundado o seu impacto.

Da mesma forma, no campo legal, o hiato jurídico precisa ser preenchido por leis que possam auxiliar o desenvolvimento humano e tecnológico de modo combinado, não deixando o humano à mercê dos reflexos da tecnologia.

Enquanto apenas a ética individual for a barreira mais relevante das condutas de captura e cruzamento de dados individuais e identificáveis, as bases de dados das memórias infotécnicas podem seguir ampliando seus territórios e seu capital de dados. 
Ainda que alguns comportamentos e coleta de dados poderiam ser considerados antiéticos, podem não necessariamente ser ilegais.

O desenvolvimento desta obra ampliou a percepção de seu autor que indica ser necessária a revisão da base legal, que está definida sob jurisdição territorialista, lançando seus efeitos jurídicos apenas nos domínios de seu território mas não agindo para salvaguardar direitos humanos violados por brasileiros fora do país.

Diversos crimes na internet seguem impunes pela incongruência e irreflexividade da estrutura legal quando confrontada com as práticas globais atuais.

Um crime contra os brasileiros, como coleta indevida de dados, só estará imputável e talvez punível na medida em que ocorra no território nacional ou de acordo com acordos jurídicos multilaterais entre alguns países. Porém a internet não respeita estas fronteiras. Hospedados em países "neutros", criminosos seguem praticando crimes que podem ocorrer através de um acesso originado em cada lar brasileiro.

Por outro lado, muitas atividades não tuteladas seguem licitamente sendo executadas sem que haja um olhar profundo sobre os seus reflexos presentes e futuros sobre o futuro e o passado.

A memória infotécnicas é uma criatura quimérico que só faz crescer nos dias atuais. Se seu crescimento será cerceado ou se suas consequências serão boas ou más pouco se pode garantir. Reflexos positivos e negativos com certeza existirão, mas que sejam produto das escolhas humanas conscientes. 


\section{REFERÊNCIAS}

ALVES, José Cláudio Rodrigues; Rodrigues, Monica Walter. A memória coletiva e o direito ao esquecimento. In: VII Congresso Brasileiro da Sociedade da Informação, 2014, São Paulo. Regulamentação da Mídia na Sociedade da Informação. São Paulo: Anais do congresso, 2014. P. 84 - 90)

ABREU, Giovanna; NICOLAU, Marcos. Big data e autonomia do usuário: os resumos de um futuro dataficado. VIII Simpósio Nacional, ABCiber, 2014.

AMARAL, Adriana. Subculturas e cibercultura(s): Para uma genealogia das identidades de um campo. In: A cibercultura em transformação: poder, liberdade e sociabilidade em tempos de compartilhamento, nomadismo e mutação de direitos. TRIVINHO, Eugênio; REIS, Angela Pintor dos (orgs.). São Paulo : ABCiber; Instituto Itaú. Cultural, 2010, p. 48 58.

ARAÚJO, Denize Correa (org). Imagem (ir)realidade: Comunicação e cibermídia. Porto Alegre: Editora Sulina, 2006.

ASSANGE, Julian [at al.]. Cypherpunks: Liberdade e o futuro da internet. Boitempo, 2012.

BAUMAN, Zygmunt. Identidade. Rio de Janeiro: Editora Zahar, 2005.

BAUDRILLARD, Jean. De um fragmento a outro. São Paulo: Zouk, 2003.

BERNARDO, Teresinha. Memória: suas possibilidades nas Ciências Sociais. Revista Aurora, Memória II, São Paulo, n. 11, p. 100 - 103, 2011)

BRAGA, José Luiz. Nem rara, nem ausente - tentativa. Revista MATRIZes, São Paulo, v.4, n. 1, p. $65-81$, jul/dez, 2010.

BRUNO, Fernanda. Máquinas de ver, modos de ser: vigilância, tecnologia e subjetividade. Porto Alegre: 2013.

CORSO, Aline. Reflexões sobre privacidade e vigilância na era dos computadores vestíveis. VIII Simpósio Nacional da ABCiber, 2014.

CURY, Lucilene. O dilema da pesquisa. São Paulo: Edusp, 2008.

DEBORD, Guy. A sociedade do espetáculo. Rio de Janeiro: Editora Contraponto, 1997. 
DESCHAMPS, Jean-Claude; MOLINER, Pascal. A identidade em psicologia social: Dos processos identitários às representações sociais. Petrópolis: Editora Vozes, 2008.

DOBELLI, Rolf. A arte de pensar claramente. Rio de Janeiro: Editora Objetiva, 2011.

REIS, Bruno Carriço. Memórias colectivas; o passado reconstruído, o presente (des)construído. Revista Aurora, Memória, São Paulo, n. 10, p. 9 - 15, 2011)

DODEBEI, Vera Doyle. Memória e patrimônio: perspectivas de acumulação/dissolução no ciberespaço. Revista Aurora, Memória, São Paulo, n. 10, p. 36 - 50, 2011)

FAVA, Gihana Proba. N=tudo: Reflexos da onipresença e onisciência em uma rede mediada por algoritmos. VIII Simpósio Nacional, ABCiber, 2014.

FELINTO, Erick. Em busca do tempo perdido. O sequestro da história na cibercultura e os desafios da teoria da mídia. Revista MATRIZes, São Paulo, v.4, n. 2, p. 43 -56, jan/jun, 2011.

FERRARA, Lucrécia D'Alessio. Ciberespaço: Conceito à procura de um nome. In: A cibercultura em transformação: poder, liberdade e sociabilidade em tempos de compartilhamento, nomadismo e mutação de direitos. TRIVINHO, Eugênio; REIS, Angela Pintor dos (orgs.). São Paulo : ABCiber; Instituto Itaú. Cultural, 2010, p. 60 - 69.

FRAGOSO, Suely. Cunctus ergo sum: Crítica à compreensão cartesiana de sujeito nos estudos da cibercultura. VIII Simpósio Nacional, ABCiber, 2014.

FOUCAULT, Michel. Vigiar e punir: nascimento da prisão. Petrópolis: Vozes, 2013 (1975).

GOFFMAN, Erving. A representação do eu na vida cotidiana. Petrópolis: Vozes, 1975.

GOMES, Maria Cristina Marques. Sociedade da informação e o direito digital. Revista Cadernos de Iniciação Científica, São Bernardo do Campo, n. 10, p. 87 - 92, 2013)

HALL, Stuart. A identidade cultura na pós-modernidade. $10^{\mathrm{a}}$ ed. Rio de Janeiro: DP\&A, 2005 .

JOST, François. Novos comportamentos para antigas mídias ou antigos comportamentos para novas mídias. Revista MATRIZes, São Paulo, v.4, n. 2, p. 93 - 109, jan/jul, 2011

KAHNEMAN, Daniel. Rápido e devagar: Duas formas de pensar. Rio de Janeiro: Objetiva, 2011. 
KRAMER, Adam D. I.; GUILLORY, Jamie E.; HANCOCK, Jeffrey T. Experimental evidence of massive-scale emotional contagion through social networks. PNAS, n. 29, v. 111, p. $8.878-8790$, junho de 2014 .

LA BOÉTIE, Étienne de. Discurso da servidão voluntária. São Paulo: Martin Claret, 2009 (1576).

LÉVY, Pierre. O que é o virtual? São Paulo: Editora 34, 1996.

Cibercultura São Paulo: Editora 34, 1999.

LONDON, Jack. Adeus, facebook: O mundo pós-digital. Rio de Janeiro: Editora Valentina, 2012.

MAFESOLLI, Michel. Religação imaginal, in: ARAÚJO, Denise Correa (org). Imagem (ir)realidade, comunicação e cibermídia. Porto Alegre: Sulina, 2006.

MARTINEZ, Pablo Domingues. Direito ao esquecimento: A proteção da memória individual na sociedade da informação. Rio de Janeiro: Editora Lumen Juris, 2014.

MAYER-SCHÖNBERGER,Viktor. Delete: The virtue of Forgetting in the Digital Age. Princeton: Princeton University Press, 2009.

MILLER, Toby. Cidadania Cultural. Revista MATRIZes, São Paulo, v.4, n. 2, p. 57 - 74, jan/jun, 2011.

PALÁCIOS, Marcos. Convergência e memória: jornalismo, contexto e história. Revista MATRIZes, São Paulo, v.4, n. 1, p. 37 - 50, jul/dez, 2010.

A memória como critério de aferição de qualidade no ciberjornalismo. Alguns apontamentos. Revista FAMECOS, Porto Alegre, n. 37, p. 91-100, dezembro, 2008. PARISER, Eli. O filtro invisível: O que a internet está escondendo de você. Rio de Janeiro: Zahar, 2012.

PARRA, Henrique Z. M. Tecnologias de imagem e políticas identitárias. Revista Aurora, Artes e Mídias Digitais, São Paulo, n. 8, 2010)

PENTZOLD, Christian; SOMMER, Vivien. Digital networked media and social memory. Theoretical foundations and implications. Revista Aurora, Memória, São Paulo, n. 10, p. 72 $85,2011)$

SANTAELLA, Lúcia. Corpo e comunicação: sintoma da cultura. São Paulo: Paulus, 2004. 
Linguagens líquidas na era da mobilidade. São Paulo: Paulus, 2007.

SANTOS, Emanuella; NICOLAU, Marcos. Web 2.0 numa sociedade vigiada: Google, Colaboração e privacidade na rede. VIII Simpósio Nacional, ABCiber, 2014.

SILVA, Juremir Machado. As tecnologias do imaginário. Porto Alegre: $3^{\text {a }}$ edição, Sulina, 2012.

SILVA, Adriana Souza e. Do ciber ao híbrido: tecnologias móveis como interfaces de espaços híbridos, in: ARAÚJO, Denise Correa (org). Imagem (ir)realidade, comunicação e cibermídia. Porto Alegre: Sulina, 2006.

SILVEIRA, Sergio Amadeu da. Cibercultura, commons e feudalismo informacional. In: A cibercultura em transformação: poder, liberdade e sociabilidade em tempos de compartilhamento, nomadismo e mutação de direitos. TRIVINHO, Eugênio; REIS, Angela Pintor dos (orgs.). São Paulo : ABCiber; Instituto Itaú. Cultural, 2010, p. 81 - 88.

SOARES, Elisianne Campos de Melo. Internet, memória onipresente - Direito ao Esquecimento versus Direito à informação. VIII Simpósio Nacional, ABCiber, 2014.

TAPSCOTT, Don. Grown up digital: how the net generation is changing your world. McGrawHill: 2009.

TAVARES, Luis Eduardo. Cultura Livre: projeto de ação política no capitalismo informacional. Revista Aurora, Internet, São Paulo, n. 4, p. 251 - 268, 2009)

THOMPSON, John B. Fronteiras cambiantes da vida pública e privada. Revista MATRIZes, São Paulo, v.4, n. 1, p. 11 - 36, jul/dez, 2010.

TRIVINHO, Eugênio. A dromocracia cibercultural: Lógica da vida humana na civilização mediática avançada. São Paulo: Paulus, 2007.

WERTSCH, James V. Collective remembering. Revista Aurora, Memória II, São Paulo, n. 11, p. 9 - 15, 2011)

WOLF, Mauro. Teorias das comunicações de massa. São Paulo: Martins Fontes, 2009.

WOLTON, Dominique. Internet, e depois? Uma teoria crítica das novas mídias. Porto Alegre: Sulina, 2003.

WIENER, Norbert. Cibernética e sociedade: $O$ uso humano de seres humanos. São Paulo: Cultrix, 1954. 